\title{
ECOLOGICAL SECURITY OF A MARINE COMBUSTION ENGINE - A FORMAL APPROACH \\ BEZPIECZEŃSTWO EKOLOGICZNE SILNIKA OKRĘTOWEGO - PODEJŚCIE FORMALNE
}

\author{
Jerzy Merkisz, Leszek Piaseczny \\ Politechnika Poznańska, Akademia Marynarki Wojennej w Gdyni \\ e-mail: jerzy.merkisz@put.poznan.pl,
}

\begin{abstract}
The authors have formed a definition of ,ecological security of a marine combustion engine" originating from a general notion of 'security'. The process of changes of the engine condition influencing the ecological security has been described formally. Based on this process the authors have introduced the notion of structural function of an engine and the structure of its ecological security. The state of ecological security of an engine as a whole has been formulated as a stochastic process and the function, being a one-dimensional distribution of this process, has been used as a measure of the ecological security of an engine at any given moment in its service life. A general example of optimization of this structure has been given based on the fulfillment by the engine of the requirements related to the emission of nitric oxides. It has been assumed that the actions taken aiming at the fulfillment of these requirements allow an obtainment of certain structures of the engine ecological security.
\end{abstract}

Keywords: marine combustion engine, ecological security, structure of ecological security, optimization of ecological security.

Streszczenie: Autorzy sformułowali zakres pojęciowy „bezpieczeństwa ekologicznego okrętowego silnika spalinowego" wychodzac z ogólnego zakresu pojęcia „, bezpieczeństwa”. Opisano formalnie proces zmian stanów silnika mających wpływ na jego bezpieczeństwo ekologiczne. Na bazie tego procesu wprowadzono pojęcie funkcji strukturalnej silnika i struktury jego bezpieczeństwa ekologicznego. Stan bezpieczeństwa ekologicznego silnika jako catości sformutowano jako proces stochastyczny, a funkcje będaca jednowymiarowym rozkładem procesu wykorzystano jako miarę bezpieczeństwa ekologicznego silnika $w$ dowolnej chwili jego istnienia. Podano ogólny przyktad optymalizacji tej struktury na podstawie spetnienia przez silnik wymogów dotyczących emisji jednostkowe tlenków azotu. Zatożono, że podejmowane działania mające na celu spetnienie tych wymagań pozwalaja uzyskać określone struktury bezpieczeństwa ekologicznego silnika.

Stowa kluczowe: okrętowy silnik spalinowy, bezpieczeństwo ekologiczne, struktura bezpieczeństwa ekologicznego, optymalizacja bezpieczeństwa ekologicznego. 
Ecological security of a marine combustion engine - a formal approach

Bezpieczeństwo ekologiczne silnika okrętowego-podejście formalne

\section{Introduction}

The term 'security' is generally associated with a state of tranquility, certainty and lack of jeopardy [1]. The state of tranquility, certainty and lack of jeopardy in such an understanding of security must be related to a specified area of analysis. Hence, the security of the areas under analysis denotes a state of lack of formulated risks that are greater than the admissible ones. Relating the term 'security' to the areas of analysis very often substantiates associating it to the adjective indicating the kind of 'security'. In terms of 'political areas of analysis' we can distinguish 'global security', 'regional security', 'national security' etc. By relating security to the geographical area of countries we can distinguish 'internal and external security'. Taking into account the areas of analysis understood as functioning of countries we can distinguish: 'military security', 'energy security', 'social security' and 'ecological security'. The latter, in marine transportation, can be treated in an even more narrow sense, i.e. ecological security of seafaring', 'ecological security of seaports", 'ecological security of vessels'.

By narrowing down the area of analysis of a single vessel to its engine we can obviously analyze the 'energy security of a marine engine'. Hence, the ecological security of a marine engine is such a state of the area of analysis covering the marine engine in which all the perils formulated in this area do not generate a risk greater than the admissible one.

Air pollution with the toxic exhaust components constitutes the greatest risk. Similar risk is associated with the pollution from the exhaust gas generated by boilers and waste incinerators, noise emissions and vibrations generated during engine operation, risks related to the heat energy transferred to seawater with the cooling water and the exhaust as well as the risks related to compounds based on crude oil (fuel and lubricant) in the form of liquid or vapor. The greatest risk, however, is the exhaust emissions related disadvantages for humans and natural environment.

An example of such a risk is the possibility of sustaining damage by people and the natural environment as a result of excessive emissions of the sulfur oxides. The source of the risk in this case is the presence of sulfur in the marine fuel. An admissible risk is reached at the unit emission of sulfur oxides of $2 \mathrm{~g} /(\mathrm{kW} \cdot \mathrm{h})$. When the level of the unit emission of sulfur oxides exceeds the admissible value it is necessary to take action using procedures related to the risk. In this particular case action is taken to reduce the sulfur content in marine fuel (avoidance of the sources of risk) or exhaust gas aftertreatment (reduction of risk).

In this paper the authors attempted to generally and formally describe the ecological security of a marine combustion engine. Based on the formal descriptions the problems of engine ecological security optimization were formulated in terms of its compliance with the exhaust emission requirements. The optimization can be analyzed according to a variety of criteria. 


\section{The process of changes of the engine condition}

We can assume that an engine is composed of $n$ number of elements. Let $\mathbf{N}=\{1,2$, $\ldots, n\}$ be a set of numbers of the engine elements.

At any moment of the engine service life the engine elements have a certain technical condition and act on the environment in an individual way. We assume that technical conditions of engine elements influencing the environment can have numbers assigned to them. These numbers we will refer to as the conditions of elements. Symbol $\mathbf{S}_{\mathbf{k}}$ will denote a set of all conditions of elements of the number $\mathrm{k} \in \mathbf{N}$.

We assume that in set $\mathbf{S}_{\mathbf{k}}$ a relation of the partial order $\underset{k}{\prec}$ is determined, hence a relation fulfilling the following conditions:

$$
\begin{aligned}
& \bigwedge_{\mathrm{x} \in \mathbf{S}_{\mathrm{k}}}^{\mathrm{X}} \underset{\mathrm{k}}{\prec \mathrm{y}} \\
& \bigwedge_{\mathrm{x}, \mathrm{y}, \mathrm{z} \in \mathrm{S}_{\mathrm{k}}}\left[(\underset{\mathrm{k}}{\mathrm{x} \prec \mathrm{y}}) \wedge(\underset{\mathrm{k}}{\mathrm{y}} \underset{\mathrm{z}}{ }) \Rightarrow \mathrm{x}_{\mathrm{k}} \prec \mathrm{z}\right] \\
& \bigwedge_{\mathrm{x}, \mathrm{y} \in \mathrm{S}_{\mathrm{k}}}[(\underset{\mathrm{k}}{\mathrm{x}} \underset{\mathrm{y}}{\prec}) \wedge(\underset{\mathrm{k}}{\mathrm{y}} \underset{\mathrm{x}}{\prec}) \Rightarrow \mathrm{x}=\mathrm{y}]
\end{aligned}
$$

in individual models the notation $\underset{\mathrm{k}}{\mathrm{x}} \prec \mathrm{y}$ can be interpreted that condition $\mathrm{x}$ of element of number $\mathrm{k}$ is ,not better” than condition y of this element.

Cartesian product

$$
\mathbf{S}=\mathbf{S}_{1} \times \mathbf{S}_{2} \times \ldots \times \mathbf{S}_{\mathrm{n}}
$$

determines the condition of all engine elements.

The state of engine influence on the natural environment as a whole depends on the states of influence on the environment of all of its individual elements i.e. their conditions (in terms of exhaust emissions) and mutual structural relations [2]. For example an engine element is its combustion chamber inside the cylinder, a fuel injector, the lubrication, supercharging or SCR systems used for the reduction of nitric oxides in the exhaust gas with the use of ammonia at the presence of a catalyst.

Let $\mathbf{Z}$ denote a set of object states as a whole. We assume that this set is ordered by the relation written as follows (3).

We refer to function

$$
\varphi: \mathbf{S} \stackrel{\text { na }}{\longrightarrow} \mathbf{Z}
$$

as engine structural function [3].

We refer to pair $\langle\mathbf{N}, \varphi\rangle$ as the structure of engine ecological security. 
Ecological security of a marine combustion engine - a formal approach Bezpieczeństwo ekologiczne silnika okrętowego-podejście formalne

We call the structure coherent if the following implication takes place

$$
\left(\underset{\mathrm{k} \in \mathbf{N}}{\wedge} \mathrm{x}_{\mathrm{k}} \underset{\mathrm{k}}{\prec} \mathrm{y}_{\mathrm{k}}\right) \Rightarrow \varphi\left(\mathrm{x}_{1}, \ldots, \mathrm{x}_{\mathrm{n}}\right) \prec \varphi\left(\mathrm{y}_{1}, \ldots, \mathrm{y}_{\mathrm{n}}\right)
$$

This property tells us that a deterioration of the condition of the engine elements increases the negative impact on the environment.

Let $\mathrm{T} \subset \mathrm{R}_{+}$denote the period of engine service life. The condition of the engine elements is changed during its life cycle and these changes are most frequently random. The stochastic process $\left\{X_{k}(t) ; t \in T\right\}$ of the set of conditions $S_{k}$ we refer to as the process of changes of the condition of the engine elements. For each steady $\mathrm{t} \in \mathrm{T}, \mathrm{X}_{\mathrm{k}}(\mathrm{t})$ is a random variable denoting the condition of $\mathrm{k}$-th element in moment $\mathrm{t}$.

The vector process

$$
\mathrm{X}(\mathrm{t})=\left(\mathrm{X}_{1}(\mathrm{t}), \ldots, \mathrm{X}_{\mathrm{k}}(\mathrm{t})\right)
$$

of the values in set $\mathbf{S}=\mathbf{S}_{1} \times \mathbf{S}_{2} \times \ldots \times \mathbf{S}_{\mathrm{n}}$ is determined by the collective conditions of all engine elements in moment $\mathrm{t}$.

The stochastic process

$$
\mathrm{Y}(\mathrm{t})=\varphi(\mathrm{X}(\mathrm{t}))
$$

of the values in set $\mathrm{Z}$ denotes the ecological security as a whole in moment $\mathrm{t} \in \mathrm{T}$.

$$
\text { Let } \mathbf{B} \subset \mathbf{Z}
$$

Function

$$
\mathrm{P}(\mathrm{t}, \mathbf{B})=\mathrm{P}_{\mathrm{r}}\{\mathrm{Y}(\mathrm{t}) \in \mathbf{B}\}
$$

Is a one-dimensional decomposition of the process

$$
\{\mathrm{Y}(\mathrm{t}): \mathrm{t} \in \mathrm{T}\}
$$

We should note that

$$
\mathrm{P}_{\mathrm{r}}\{\mathrm{Y}(\mathrm{t}) \in \mathbf{B}\}=\mathrm{P}_{\mathrm{r}}\{\varphi(\mathrm{X}(\mathrm{t})) \in \mathbf{B}\}=\mathrm{P}_{\mathrm{r}}\left\{\mathrm{X}(\mathrm{t}) \in \varphi^{-1}(\mathbf{B})\right\}
$$

Set $\varphi^{-1}(\mathbf{B})$ is an inverse image of set $\mathbf{B}$ in $\varphi$ :

$$
\varphi^{-1}(\mathbf{B})=\{\mathrm{s} \in \mathbf{S}: \varphi(\mathrm{s}) \in \mathbf{B}\}
$$

Particularly, if $\mathbf{B}$ is a set of engine conditions that make the engine operation impossible with all the environment protection requirements fulfilled, then $\mathrm{P}(\mathrm{t}, \mathbf{B})$ is the measure of the ecological security of an engine in moment $t$.

\section{The structure of ecological security of a marine combustion engine}

The engine can be ecologically 'formed' on the design and production stages as well as in its service life. As a result of certain actions taken on the design and production stages related to the combustion process (design of the combustion chamber, design of the fueling system, charge exchange systems etc.) application 
of aftertreatment systems we can create an engine that meets local and global regulations related to the marine environment $[4,5]$.

In a service life of an engine the process of creation of an ecological engine consists in the control of the engine load and maintaining appropriate technical conditions of the engine elements (consequently, the technical conditions of the whole engine) to meet the above-mentioned requirements and standards. Systems of on-board diagnostic are applied increasingly, whose task is to signal a loss of a required condition of the engine elements from the point of view of the environmental perils [5]. In the case of a breach of the required engine ecological security a repair service is performed.

If $t_{0}$ is the moment of initiation of service of the $\mathrm{k}$-th element, and $\tau$ is the moment of completion of this service, then for each of these actions a relation should take place

$$
\widehat{\mathrm{k} \in \mathbf{N}} \mathrm{X}_{\mathrm{k}}\left(\mathrm{t}_{\mathrm{o}}\right) \underset{\mathrm{k}}{\prec} \mathrm{X}_{\mathrm{k}}(\tau)
$$

An ecological security of an engine can be understood as its adaptation to meet the prescribed ecological standards.

The structure of engine ecological security can be analyzed based on the graph theory.

Let $\mathbf{W}=\left\{\mathrm{p}_{1}, \ldots, \mathrm{p}_{\mathrm{m}}\right\}$ be a finite set of elements and $\mathbf{U} \subset \mathbf{W} \times \mathbf{W}$ a binary relation. As we know, an ordered pair of set $\langle\mathbf{W}, \mathbf{U}\rangle$ is referred to as a graph. The elements of set $\mathbf{W}$ are called the graph vertexes and the ordered pairs $\left(p_{i}, p_{j}\right) \in \mathbf{U}$ are the arcs. If $\left(p_{i}, p_{j}\right) \in \mathbf{U}$ then we say that $p_{i}$ directly precedes $p_{j}$ and the notation is $p_{i} \prec p_{j}$.

We refer to subset $\left\{\mathrm{p}_{\mathrm{i}}, \mathrm{p}_{\mathrm{j}}\right\}$ so that $\left(\mathrm{p}_{\mathrm{i}}, \mathrm{p}_{\mathrm{j}}\right) \in \mathbf{U}$ or $\left(\mathrm{p}_{\mathrm{j}}, \mathrm{p}_{\mathrm{i}}\right) \in \mathbf{U}$ as the edge of the graph. A sequence of subsets $\left\{p_{\mathrm{k} 1}, \mathrm{p}_{\mathrm{k} 2}\right\},\left\{\mathrm{p}_{\mathrm{k} 2}, \mathrm{p}_{\mathrm{k} 3}\right\}, \ldots,\left\{\mathrm{p}_{\mathrm{ks}-1}, \mathrm{p}_{\mathrm{ks}}\right\}$ is referred to as the chain in the graph $\langle\mathbf{W}, \mathbf{U}\rangle$.

A graph $\langle\mathbf{W}, \mathbf{U}\rangle$ is non-cyclic if for any path

$$
\left(\mathrm{p}_{\mathrm{i} 1}, \mathrm{p}_{\mathrm{i} 2}\right),\left(\mathrm{p}_{\mathrm{i} 2}, \mathrm{p}_{\mathrm{i} 3}\right), \ldots,\left(\mathrm{p}_{\mathrm{is}-1}, \mathrm{p}_{\mathrm{is}}\right)
$$

we have

$$
\mathrm{p}_{\mathrm{i} 1} \neq \mathrm{p}_{\mathrm{is}}
$$

Vertex $p_{o}$ is referred to as the initial point of the graph $\langle\mathbf{W}, \mathbf{U}\rangle$ if for any $\mathrm{p}_{\mathrm{i}} \in \mathbf{W},\left(\mathrm{p}_{\mathrm{i}}, \mathrm{p}_{\mathrm{o}}\right) \notin \mathbf{U}$. Vertex $\mathrm{p}_{\mathrm{k}}$ is referred to as the graph endpoint $\langle\mathbf{W}, \mathbf{U}\rangle$ if for any $\mathrm{p}_{\mathrm{i}} \in \mathbf{W},\left(\mathrm{p}_{\mathrm{k}}, \mathrm{p}_{\mathrm{i}}\right) \notin \mathbf{U}$.

In the analyzed case of the structure of marine engine ecological security we ascribe an $\operatorname{arc} \mathrm{u}_{\mathrm{ij}}^{(r)}=\left(\mathrm{p}_{\mathrm{i}}^{(r)}, \mathrm{p}_{\mathrm{j}}^{(r)}\right)$ to each action aiming at the maintenance or improvement of the ecological security of a marine engine of r-th kind. 
Ecological security of a marine combustion engine - a formal approach Bezpieczeństwo ekologiczne silnika okrętowego-podejście formalne

Vertex $\mathrm{p}_{\mathrm{i}}^{(r)}$ we interpret as an event i.e. the initiation of an action and $\mathrm{p}_{\mathrm{j}}^{(r)}$ is the event that finishes the action. A set of all vertices we mark $\mathbf{W}_{\mathrm{r}}$ and the set of all $\operatorname{arcs} \mathbf{U}_{\mathrm{r}}$

If $\mathbf{G}_{\mathrm{r}}=\left\langle\mathbf{W}_{\mathrm{r}}, \mathbf{U}_{\mathrm{r}}\right\rangle$, corresponding to the possibility of controlling the ecological security of an r-th engine is coherent, non-cyclic and has one initial and one end vertex then we say that this graph determines the structure of the engine in terms of the possibility of controlling the ecological security of an engine of the $r$-th kind.

A set of graphs $\mathbf{G}=\left\{\mathbf{G}_{\mathrm{r}}: \mathrm{r}=1,2, \ldots, \mathrm{p}\right\}$ determines the structure of ecological security of a marine engine. The determination of the structure of ecological security of engines, as said earlier, is possible on the engine design stage. We can, thus, compare engines in terms of their structures.

\section{Examples of the problems of optimization of the structures of ecological security of a marine engine}

The problems of optimization of the structure of the ecological security can be formulated in a variety of ways assuming different criteria of optimization.

Let us assume that the condition of the engine elements is determined by a random vector

$$
\mathrm{X}(\mathrm{t})=\left(\mathrm{X}_{1}(\mathrm{t}), \ldots, \mathrm{X}_{\mathrm{n}}(\mathrm{t})\right)
$$

of the set of conditions $\mathbf{S}=\mathbf{S}_{1} \times \mathbf{S}_{2} \times \ldots \times \mathbf{S}_{\mathrm{n}}$.

The examples of optimization of the structures of the engine ecological susceptibility we will discuss on the example of fulfilling by the marine engine of the requirements related to the unit emission of nitric oxides as per annex of the VI MARPOL 73/78 convention [6].

Actions aiming at the fulfillment by the engine of the above requirements (let us mark it with operations of the r-th kind) can be realized in different ways using different methods.

Different operations of the $\mathrm{r}$-th kind will be assigned different structures of ecological security $\mathbf{G}_{\mathrm{r}}$.

Functions $T_{r}: \mathbf{G}_{\mathrm{r}} \rightarrow \mathrm{R}_{+}, \mathrm{r}=1,2, \ldots, \mathrm{p}$ assign numbers $\mathrm{T}_{\mathrm{r}}\left(\mathbf{G}_{\mathrm{r}}\right)$ to structures $\mathbf{G}_{\mathrm{r}}$ denoting the durations of actions ensuring ecological security of an engine of the $r$ th kind.

As a result of action of the $r$-th kind the k-th element of the engine returns to a technical condition or is given a technical condition that allows the fulfillment by the engine of the requirements of the VI MARPOL 73/78 convention as per test E3 [6]. Functions $\mathrm{h}_{\mathrm{k}, \mathrm{r}}: \mathbf{G}_{\mathrm{r}} \rightarrow \mathbf{S}_{\mathrm{k}} ; \mathrm{k}=1,2, \ldots, \mathrm{n} ; \mathrm{r}=1,2, \ldots, \mathrm{p}$ assign technical conditions of the engine, after performing actions of the r-th kind, to the structures of ecological security $\mathbf{G}_{\mathrm{r}}$.

The values of function $\mathrm{h}_{\mathrm{r}}: \mathbf{G}_{\mathrm{r}} \rightarrow \mathbf{Z}, \mathrm{r}=1,2, \ldots, \mathrm{p}$ determined by the formula

$$
\mathrm{h}_{\mathrm{r}}\left(\mathbf{G}_{\mathrm{r}}\right)=\varphi\left(\mathrm{h}_{1, \mathrm{r}}\left(\mathbf{G}_{\mathrm{r}}\right), \ldots, \mathrm{h}_{\mathrm{n}, \mathrm{r}}\left(\mathbf{G}_{\mathrm{r}}\right)\right)
$$


are the engine conditions (e.g. values of the engine unit emission of nitric oxides) after performing the actions of the r-th kind (aiming at e.g. the fulfillment of the requirements of the MARPOL convention as per test E3 of the standard [6]).

Function $\mathrm{R}\left(\mathrm{t}, \tau, \mathbf{G}_{\mathrm{r}}\right)=\mathrm{P}_{\mathrm{r}}\left\{\varphi\left(\left(\mathrm{x}_{1}(\mathrm{t}), \ldots, \mathrm{x}_{\mathrm{n}}(\mathrm{t})\right) \in \mathbf{Z}_{+}\left(\left(\varphi\left(\mathrm{x}_{1}(\tau), \ldots, \mathrm{x}_{\mathrm{n}}(\tau)\right)=\mathrm{h}_{\mathrm{r}}\left(\mathbf{G}_{\mathrm{r}}\right)\right.\right.\right.\right.$ denotes engine security in terms of its unit emission of nitric oxides at moment $t>$ $\tau$ under the condition that at the moment of ending of the actions aiming at the fulfillment by the engine of the ecological requirements $\tau$ was in the $h_{r}\left(\mathbf{G}_{r}\right)$ condition.

The most important issues related to the optimization of the structures of ecological security of the engine are: maximization of the efficiency of the applied actions and methods of fulfillment by the engine of the nitric oxides emission requirements and cost minimization.

The maximization of efficiency of an individual method of fulfillment by the engine of the nitric oxides emission requirements consists in finding of such a $\mathbf{G}_{\mathrm{r}}{ }^{*}$ structure as to obtain

$$
\widehat{t}_{\mathrm{t} \in[\tau, \mathrm{a}]} \mathrm{R}\left(\mathrm{t}, \tau, \mathbf{G}_{\mathrm{r}}^{*}\right)=\max _{\mathbf{G} \in \mathbf{D}_{\mathrm{r}}} \mathrm{R}\left(\mathrm{t}, \tau, \mathbf{G}_{\mathrm{r}}\right)
$$

The solution to this problem is structure $\mathbf{G}_{\mathrm{r}}{ }^{*}$ that corresponds to a method guaranteeing the highest efficiency in terms of the fulfillment by the engine of the ecological requirements determined by test $\mathrm{E} 3$ in the range $[\tau, \mathrm{a}]$.

The minimization of costs of the fulfillment by the engine of the $\mathrm{NO}_{\mathrm{x}}$ emission requirements consists in finding such a $\mathbf{G}_{\mathrm{r}}{ }_{\mathrm{r}}$ structure that will ensure that the cost of obtaining of this structure (out of all structures determined by set $\mathbf{B}$ - formula (9)) is the lowest:

$$
\mathrm{K}_{\mathrm{r}}\left(\mathbf{G}_{\mathrm{r}}^{*}\right)=\min _{\mathbf{G} \in \mathbf{B}} \mathrm{K}_{\mathrm{r}}\left(\mathbf{G}_{\mathrm{r}}\right)
$$

The solution to this problem is structure $\mathbf{G}_{\mathrm{r}}{ }^{*} \in \mathbf{B}$ that corresponds to the most costeffective method of the r-th kind.

\section{Conclusions}

The presented formal approach to the problem of ecological security of an engine and its optimization are a part of the optimization problem of ecological structures of a marine engine and correspond to pro-ecological actions of the same kind. A global approach to the problem of optimization of structures of ecological security related to the adaptation of the engine to all the ecological requirements is much more difficult not only in the design and production but also in the service and end-of-life processes of the whole engine or its individual elements.

\section{References}

[1] Stownik języka polskiego pod red M. Szymczaka. PWN, Warszawa 1978.

[2] Kniaziewicz T., Piaseczny L.: Charakterystyki toksyczności spalin silnika Sulzer typu AL20/24. Materiały II Międzynarodowej Konferencji Naukowo- 
Ecological security of a marine combustion engine - a formal approach Bezpieczeństwo ekologiczne silnika okrętowego-podejście formalne

Technicznej EXPLO-DIESEL \& GAS TURBINE'01, Vol. 1, GdańskMiędzyzdroje-Kopenhaga 2001.

[3] Grabski F., Piaseczny L.: Sformalizowany opis struktur niezawodności $i$ podatności obstugowej złożonego obiektu technicznego. Materiały V Konferencji Naukowej „Cybernetyka w gospodarce morskiej”, tom I, Gdynia 1985.

[4] Gätjens H.J., Hadler C., Götze H.J.: IMO NO${ }_{x}$ Certification of Marine Diesel Engines. Germanisher Lloyd, Department M, February 2000.

[5] Merkisz J.: Ekologiczne problem silników spalinowych. Tom 2. Wyd. Politechniki Poznańskiej, Poznań 1999.

[6] ISO 8178-4:1996, Reciprocating internal combustion engines - Exhaust emission measurement - Part 4: Test cycles for different engine applications.

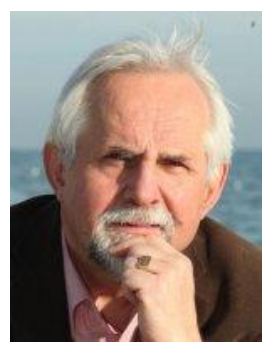

Prof. dr hab. inz. Leszek Piaseczny is a long-established scientific and didactic employee of the Mechanical-Electrical Faculty at Naval Academy in Gdynia. There, he went through all the available positions: from assistant to full professor. His main areas of scientific and didactic interest are marine piston combustion engines. He has an extensive scientific input (in excess of 250 publications) in the area of marine engine reliability, durability and operation as well as optimization of systems of operation of engine rooms. For several years his works have been focused on the reduction of the exhaust emissions from marine engines and he has been a leader of a very successful scientific team in this scientific area. For several years now he has been vice-president of Polish Scientific Society of Combustion Engines and member of the Scientific Board of the 'Combustion Engines' magazine.

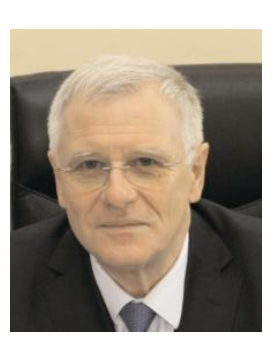

Prof. dr hab. inz. Jerzy Merkisz, dr h.c. is a full professor at Poznań University of Technology holding a position of Head of Institute of Combustion Engines and Transport. His main area of scientific interest is design and operation of machines - combustion engines particularly their ecological aspects: the problems of combustion and toxicity, types and quality of fuels and the problems of oil consumption. Additionally, professor Merkisz exhibits vast interest in transport, ecology of transport and on-board diagnostic $(O B D)$ in vehicles (he is the first to have introduced the scientific approach to the issues of $O B D$ and black box in Poland. The above-mentioned are key technologies for the reduction of the exhaust emissions from vehicles). He is the initiator, author and coordinator of the first-in-Poland PEMS- based concept and research methodology related to exhaust emissions under actual operating conditions from all modes of transport where combustion engines are applied. He is member of Society of Automotive Engineers (SAE) and European Automotive Research Partners Association in Brussels (EARPA). For several years he has been president of Polish Scientific Society of Combustion Engines and editor-in-chief of the 'Combustion Engines' magazine. 


\title{
RELIABILITY ANALYSIS OF HELICOPTER'S SUPPORTINGSTRACTURE WITH SSI AND SST MODELS USED
}

\section{ANALIZA NIEZAWODNOŚCIOWA STRUKTURY NOŚNEJ ŚMIGLOWCA MODELAMI SSI ORAZ SST}

\author{
Tomasz Bońkowski, Marta Woch
}

Politechnika Warszawska, Instytut Techniczny Wojsk Lotniczych e-mail: marta.woch@itwl.pl

\begin{abstract}
In this work, algorithms have been used to compare the methods for determining reliability of critical points. Generalized models Stress-StrengthInterference (SSI) and Stress-Strength-Time (SST) have been analyzed. Input to the algorithms, stress and strength were generated by using the Markov chain model based on actual flight records. With this approach methods of determining the reliability of critical points of a helicopter's structure are justified.
\end{abstract}

Keywords: reliability, safety, stress-strength-interference, stress-strength-time

Streszczenie: $W$ pracy dokonano próby porównania algorytmów metod wyznaczania niezawodności punktów krytycznych. Poddano analizie modele StressStrength-Interference (SSI) oraz Stress-Strength-Time (SST), której celem byto sprawdzenie zastosowań obydwu metod w rzeczywistych warunkach eksploatacji dla punktów krytycznych struktury nośnej śmigtowca. Dane wejściowe do algorytmów, czyli naprężenia w punkcie krytycznym struktury nośnej śmigłowca zostaty wygenerowane przy użyciu tańcuchów Markowa bazujacych na rzeczywistych zapisach z lotu. Dzięki takiemu podejściu metody wyznaczania niezawodności punktów krytycznych struktury helikoptera maja rzeczywiste podstawy.

Slowa kluczowe: niezawodność, bezpieczeństwo, stress-strength-interference, stress-strength-time 
Reliability analysis of helicopter's supportingstracture with SSI and SST models used Analiza niezawodnościowa struktury nośnej śmigłowca modelami SSI oraz SST

\section{Model Stress-Strength-Interference (SSI)}

Analiza ryzyka uszkodzenia struktury śmigłowca wykorzystuje probabilistyczne modele matematyczne. Zakłada ona, iż parametry charakteryzujące się niepewnością, bądź zmiennością są reprezentowane przez n-wymiarową zmienną losową zwaną wektorem losowym:

$$
\mathbf{X}=\left\{X_{1}, X_{2}, \ldots, X_{n}\right\}
$$

gdzie $X_{1}, X_{2}, \ldots, X_{n}$ sa jednowymiarowymi zmiennymi losowymi.

Uogólniona funkcja graniczna $g(\mathbf{X})$ określona na wektorze losowym definiuje stany graniczne. Zakłada się, iż uszkodzenie struktury śmigłowca następuje, gdy $g(\mathbf{X}) \leq 0$. Jeżeli $g(\mathbf{X})=0$ struktura jest $\mathrm{w}$ stanie granicznym. Funkcja graniczna pozwala zdefiniować dwa obszary w przestrzeni zdarzeń elementarnych $\Omega$ :

- obszar bezpieczny:

$$
\Omega_{s}=\{\mathbf{x}: g(\mathbf{x})>0\}
$$

- oraz obszar awarii:

$$
\Omega_{f}=\{\mathbf{x}: g(\mathbf{x}) \leq 0\}
$$

Prawdopodobieństwo awarii zdefiniowane jest następująco:

$$
P_{f}=P\left(\Omega_{f}\right)=P(g(\mathbf{x}) \leq 0)=1-R
$$

gdzie $R$ jest niezawodnością.

Powierzchnia graniczna określona jest równaniem:

$$
g(\mathbf{x})=0
$$

W analizie niezawodności krytycznych punktów śmigłowca często rozpatrywany jest przypadek, w którym funkcja graniczna $g(\mathbf{x})$ zdefiniowana jest w następujący sposób [1]:

$$
g(\mathbf{x})=X_{W}-X_{N}
$$

gdzie $X_{W}$ jest zmienną losową opisującą wytrzymałość danego punktu krytycznego, a $X_{N}$ opisuje naprężenia.

Tak zdefiniowana funkcja graniczna odpowiada podstawowemu założeniu modelu SSI, które bazuje na stwierdzeniu, iż dowolny element śmigłowca ulega uszkodzeniu wtedy, gdy wartość naprężenia $X_{N}$ występującego w tym elemencie jest większa niż wytrzymałość $X_{W}$ tego elementu. 
Dla tak zdefiniowanej funkcji granicznej prawdopodobieństwo uszkodzenia wyliczyć można za pomocą:

$$
P_{f}=P\left(X_{W}<X_{N}\right)=\int_{-\infty}^{+\infty} f_{W}\left(x_{W}\right) \int_{x_{W}}^{+\infty} f_{N}\left(x_{N}\right) d x_{N} d x_{W}
$$

gdzie $f_{N}\left(x_{N}\right)$ jest funkcją gęstości prawdopodobieństwa naprężenia, a $f_{W}\left(x_{W}\right)$ opisuje gęstość prawdopodobieństwa wytrzymałości.

Podstawowy model SSI zakłada normalny rozkład zmiennych losowych. W uogólnionym modelu (GSSI) rozkład brzegowy $f_{N}\left(x_{N}\right)$ i $f_{W}\left(x_{W}\right)$ może być opisany dowolną funkcją. Niezawodność w takim modelu można wyznaczyć za pomocą [1]:

$$
R=P\left(X_{W} \geq X_{N}\right)=\int_{0}^{2 x_{W}} F_{W}\left(x_{W}\right) f_{N}\left(x_{W}\right) d x_{W}=\int_{0}^{2 x_{W}} F_{N}\left(x_{W}\right) f_{W}\left(x_{W}\right) d x_{W}
$$

gdzie $\quad F_{N}=\int_{0}^{x_{N}} f_{N}\left(x_{N}\right) d x_{N}$ jest dystrybuantą zmiennej $X_{N}$, analogicznie $F_{W}=\int_{0}^{x_{W}} f_{W}\left(x_{W}\right) d x_{W}$ jest dystrybuantą zmiennej $X_{W}$.

Model SSI opisuje prawdopodobieństwo uszkodzenia struktury nośnej śmigłowca kiedy następuje jednokrotny wzrost wartości naprężenia.

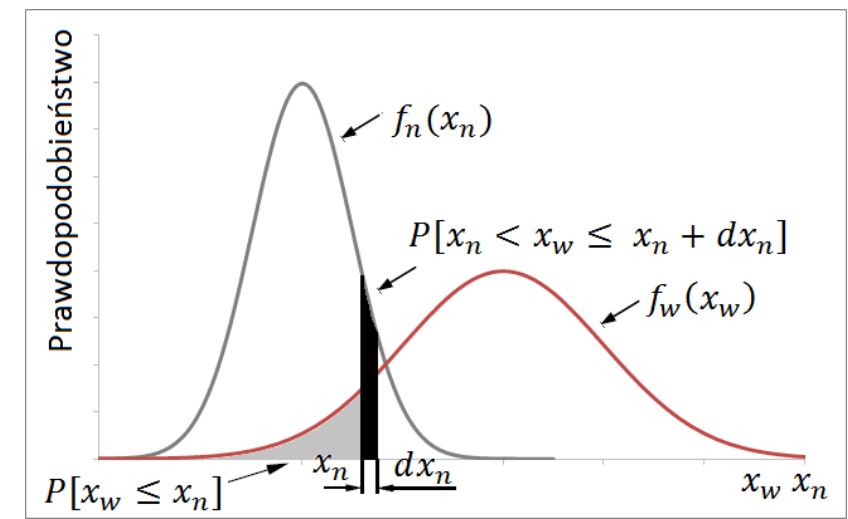

Rys. 1. Graficzna interpretacja prawdopodobieństwa uszkodzenia

\section{Model Stress-Strength-Time (SST)}

Model SST zakłada, iż wartości sił oraz naprężeń w punktach krytycznych są pewnymi ciągłymi funkcjami czasu, tak jak jest to obserwowalne w rzeczywistości. Zauważono, iż przy obliczeniach niezawodnościowych funkcje te mogą być przedstawione $\mathrm{w}$ postaci analitycznej, albo opisane za pomocą rozkładów zmiennych losowych. Wprowadzono podział modelu SST na trzy ogólne warianty [1]: 
Reliability analysis of helicopter's supportingstracture with SSI and SST models used Analiza niezawodnościowa struktury nośnej śmigłowca modelami SSI oraz SST

1) Model deterministyczny zakłada, iż wytrzymałość oraz naprężenie są dokładnie zdefiniowane, albo zmieniają się w sposób znany i przewidywalny, możliwy do opisania za pomocą funkcji matematycznych.

2) Model quasi - probabilistyczny (Random - Fixed) zakłada, iż wytrzymałość oraz naprężenie zmieniają się w sposób znany i przewidywalny w czasie, ale nie są znane wartości stałych parametryzujących opis równania.

3) Model probabilistyczny (Random-Independent) zakłada, iż zarówno naprężenie jak i wytrzymałość są zmiennymi losowymi o wartościach statystycznie niezależnych.

W normalnych warunkach eksploatacji śmigłowców mamy do czynienia z przypadkiem SST $(2,3)$ gdzie naprężenia są opisane losowymi wartościami $x_{N}$, statystycznie niezależnymi o takim samym rozkładzie prawdopodobieństwa $f_{N}\left(x_{N}\right)$. Wytrzymałość jest quasi - probabilistyczną zmienną o znanym rozkładzie $f_{W}\left(x_{W}\right)$. Dla tak zdefiniowanego modelu niezawodność $R_{n}$ konstrukcji po $n$-tym cyklu działania obciążenia może być wyznaczona za pomocą:

$$
R_{n}=P\left(E_{1}\right) \times P\left(E_{2}\right) \times \ldots \times P\left(E_{n}\right)=\left(\int_{0}^{\infty} f_{W}\left(x_{W}\right)\left\{\int_{0}^{x_{N}} f_{N}\left(x_{N}\right) d x_{N}\right\} d x_{W}\right)^{n}
$$

Model ten zakłada, iż czas nie jest zmienną losową, a długość cyklu jest znana, jednakowa dla każdego obciążenia. Podstawowy model SST zakłada normalny rozkład zmiennych losowych. W uogólnionym modelu (GSST) rozkład brzegowy $f_{N}\left(x_{N}\right)$ i $f_{W}\left(x_{W}\right)$ może być dowolnie zdefiniowany. Niezawodność $\mathrm{w}$ takim modelu można wyznaczyć za pomocą:

$$
R_{n}=\left[\int_{0}^{2 x_{W}} F_{W}\left(x_{W}\right) f_{N}\left(x_{W}\right) d x_{W}\right]^{n}=\left[\int_{0}^{2 x_{W}} F_{N}\left(x_{W}\right) f_{W}\left(x_{W}\right) d x_{W}\right]^{n}
$$

\section{Modele Markov'a}

W nawiązaniu do [2] łańcuch Markov'a pierwszego rzędu (FCM) wraz ze zdefiniowaną skończoną podprzestrzenią $E$ jest sekwencją losowych wartości z tej podprzestrzeni $\left(X_{n}\right)_{n \in \mathrm{N}}$. Warunkowy rozkład wartości $X_{n+1}$ uzyskanych na podstawie znajomości wartości $\left(X_{m}\right)_{m \leq n}$ jest tożsamy z rozkładem $X_{n+1}$ gdy znana jest tylko wartość $X_{n}$ :

$$
P\left(X_{n+1}=e_{n+1} \mid\left(X_{n}=e_{n}, X_{n-1}=e_{n-1}, \ldots, X_{1}=e_{1}\right)\right)=P\left(X_{n+1}=e_{n+1} \mid X_{n}=e_{n}\right)
$$

Jeśli $K$ jest liczbą zdefiniowanych klas można zdefiniować macierz $\mathbf{P}(K \times K)$ prawdopodobieństwa przejścia z klasy $i$ do klasy $j$ : 


$$
\mathrm{P}=\left(\begin{array}{cccc}
p_{1,1} & p_{1,2} & \cdots & p_{1, K} \\
p_{2,1} & p_{2,2} & \cdots & p_{2, K} \\
\cdots & \cdots & \cdots & \cdots \\
p_{K, 1} & p_{K, 2} & \cdots & p_{K, K}
\end{array}\right), \quad \sum_{j=1}^{K} p_{i, j}=1, \quad 0 \leq p_{i, j} \leq 1
$$

gdzie $i=1, \ldots K, p_{i, j}=P\left(X_{n+1}=e_{j} \mid X_{n}=e_{i}\right)$.

W celu wygenerowania następnej wartości z łańcucha Markov'a $X_{n+1}$ wymagana jest znajomość tylko poprzedniej wartości $X_{n}=e_{n}$. Prawdopodobieństwo iż $X_{n+1}=e_{n+1}$ wynosi $p_{n, n+1}$.

Ukryty model Markov'a (HMM) [3, 4] bazuje na koncepcji z łańcuchów Markov'a oraz obserwacji iż wartość $X$ nie jest tylko dyskretnym stanem zależnym od $E$, ale jest funkcja prawdopodobieństwa tego stanu. Łańcuch jest zdefiniowany jako dwuwymiarowy, dyskretny w czasie proces $\left\{S_{n}, X_{n}\right\}_{n>0}$. W celu wygenerowania kolejnej wartości $X_{n+1}$ należy wybrać funkcję ja $S_{k}$ bazując na znanej poprzedniej wartości $X_{n}$. Wartość $e_{n+1}$ jest generowana na podstawie funkcji $S_{k}$.

\section{Funkcja prawdopodobieństwa wytrzymałości}

W celu wyznaczenia rozkładu prawdopodobieństwa wytrzymałości testowano próbki ze stali 30HGSNA o średnicy 5-8 mm. Poprzez wytrzymałość elementu rozumiane jest przekroczenie granicy sprężystości. Uzyskane wyniki przedstawiono w tabeli 1 [5]:

Tabela 1 Granica plastyczności dla badanych stalowych próbek

\begin{tabular}{|c|c|c|c|c|c|c|c|c|c|}
\hline Nr. próbki & $2 / 05 / 2$ & $2 / 05 / 3$ & $2 / 05 / 4$ & $2 / 05 / 5$ & $2 / 05 / 36$ & $2 / 05 / 61$ & $2 / 05 / 62$ & $2 / 05 / 64$ & $2 / 05 / 132$ \\
\hline $\mathrm{R}_{0.05}[\mathrm{MPa}]$ & 1160 & 1145 & 1150 & 1200 & 1230 & 1230 & 1240 & 1175 & 1175 \\
\hline Nr. próbki & $2 / 05 / 133$ & $2 / 05 / 134$ & $2 / 05 / 135$ & $2 / 05 / 136$ & \begin{tabular}{l|l}
6 & $2 / 05 / 137$ \\
\end{tabular} & $2 / 05 / 138$ & \begin{tabular}{l|l}
$2 / 05 / 13$ \\
\end{tabular} & \begin{tabular}{l|l}
39 & $2 / 05 / 14$ \\
\end{tabular} & $102 / 05 / 141$ \\
\hline $\mathrm{R}_{0.05}[\mathrm{MPa}]$ & 1235 & 1280 & 1290 & 1330 & 1220 & 1225 & 1235 & 1240 & 1250 \\
\hline
\end{tabular}

Na podstawie wyników zaproponowano funkcję rozkładu wytrzymałości opisaną za pomocą rozkładu normalnego $g(y)$ o wartości oczekiwanej wynoszącej $\mu=1219$ and $i$ wariancji równej $\sigma^{2}=110^{2}$.

$$
f_{W}\left(x_{W}\right)=\frac{1}{\sqrt{2 \pi 110^{2}}} \exp \left(\frac{-(x-1219)^{2}}{2 \cdot 110^{2}}\right)
$$

\section{Funkcja prawdopodobieństwa naprężenia}

Krytyczny element struktury śmigłowca Mi-24, przedstawiony na rys. 2 został zeskanowany przy użyciu skanera 3D ATOS III (Advanced Topometric System) [6]. Bazując na uzyskanym modelu zaprojektowano kształt w programie Unigraphics. Obliczenia wykonano przy pomocy programu MSC Marc. Analizę przeprowadzono $\mathrm{z}$ założeniem liniowej zależności pomiędzy naprężeniem i odkształceniem materiału. Rozkład i wartości naprężeń zredukowanych według 
Reliability analysis of helicopter's supportingstracture with SSI and SST models used Analiza niezawodnościowa struktury nośnej śmigłowca modelami SSI oraz SST

hipotezy Hubera i naprężeń maksymalnych głównych w węzłach mocowania poszczególnych elementów przy obciążeniu siłami jednostkowymi. Maksymalna wartość maksymalnego naprężenia głównego wyniosła 2880 Pa przy obciążeniu siłami jednostkowymi.

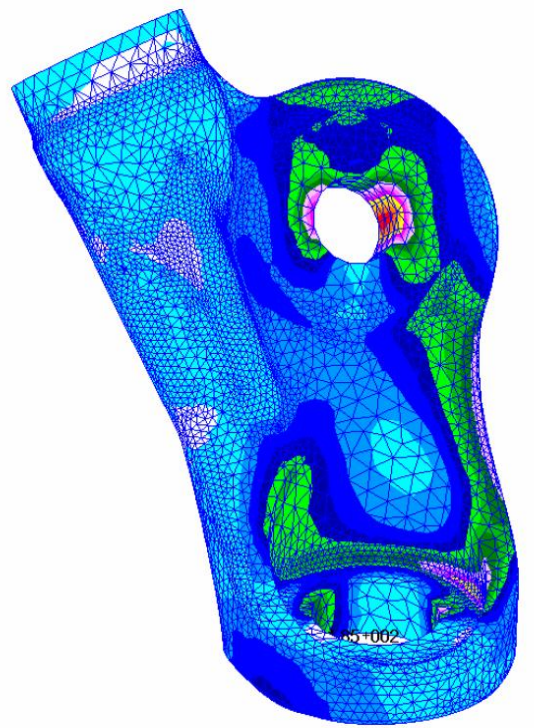

Rys. 2. Rozklad naprężeń zredukowanych w elemencie krytycznym

$\mathrm{Na}$ podstawie obliczeń rozkład naprężeń został wygenerowany dla danego elementu krytycznego.

Funkcja rozkładu naprężeń w punkcie krytycznym może być opisana za pomocą rozkładu normalnego $f_{N I}$ o wartości oczekiwanej wynoszącej $\mu=70$ and i wariancji równej $\sigma^{2}=25^{2}$.

$$
f_{N 1}\left(x_{N}\right)=\frac{1}{\sqrt{2 \pi 25^{2}}} \exp \left(\frac{-(x-70)^{2}}{2 \cdot 25^{2}}\right)
$$

$\mathrm{Na}$ podstawie histogramu naprężeń, dane podzielono na osiem klas $\mathrm{c}_{\mathrm{k}}$. $\mathrm{W}$ modelu wygenerowanym $\mathrm{z}$ łańcucha Markowa, cykle naprężeń należące do klasy $c_{i}$ zostały zastąpione przez odpowiadające im wartości $s_{i}$ pokazane $w$ tabeli 2 :

Tabela 2 Dyskretny rozkład prawdopodobieństwa naprężenia $f_{N 2} z$ tańcucha Markov'a

\begin{tabular}{|c|c|c|c|c|c|c|c|c|}
\hline $\mathrm{s}_{\mathrm{i}}$ & 15 & 30 & 45 & 60 & 75 & 95 & 140 & 180 \\
\hline $\mathrm{p}_{\mathrm{i}}$ & 0,0034 & 0,0629 & 0,0698 & 0,2699 & 0,1733 & 0,3094 & 0,1084 & 0,0025 \\
\hline
\end{tabular}

W przypadku wykorzystania do obliczeń ukrytego modelu Marcov'a, skończoną podprzestrzeń $E$ podzielono na 5 części. Dystrybuanta rozkładu naprężeń dla tego modelu może być opisana funkcją $f_{N 3}(4)$ : 


$$
f_{N 3}\left(x_{3}\right)=\left\{\begin{array}{cc}
0 & x<10 \\
\frac{0,03}{\sqrt{2 \pi 1,5^{2}}} \exp \left(\frac{-(x-17)^{2}}{2 \cdot 1,5^{2}}\right) & 10 \leq x<20 \\
\frac{0,03}{\sqrt{2 \pi 1,5^{2}}} \exp \left(\frac{-(x-24)^{2}}{2 \cdot 1,5^{2}}\right) & 20 \leq x<30 \\
\frac{0,38}{\sqrt{2 \pi 3,6^{2}}} \exp \left(\frac{-(x-53)^{2}}{2 \cdot 3,6^{2}}\right) & 30 \leq x<60 \\
\frac{0,6}{\sqrt{2 \pi 12^{2}}} \exp \left(\frac{-(x-80)^{2}}{2 \cdot 12^{2}}\right) & x \geq 60
\end{array}\right.
$$

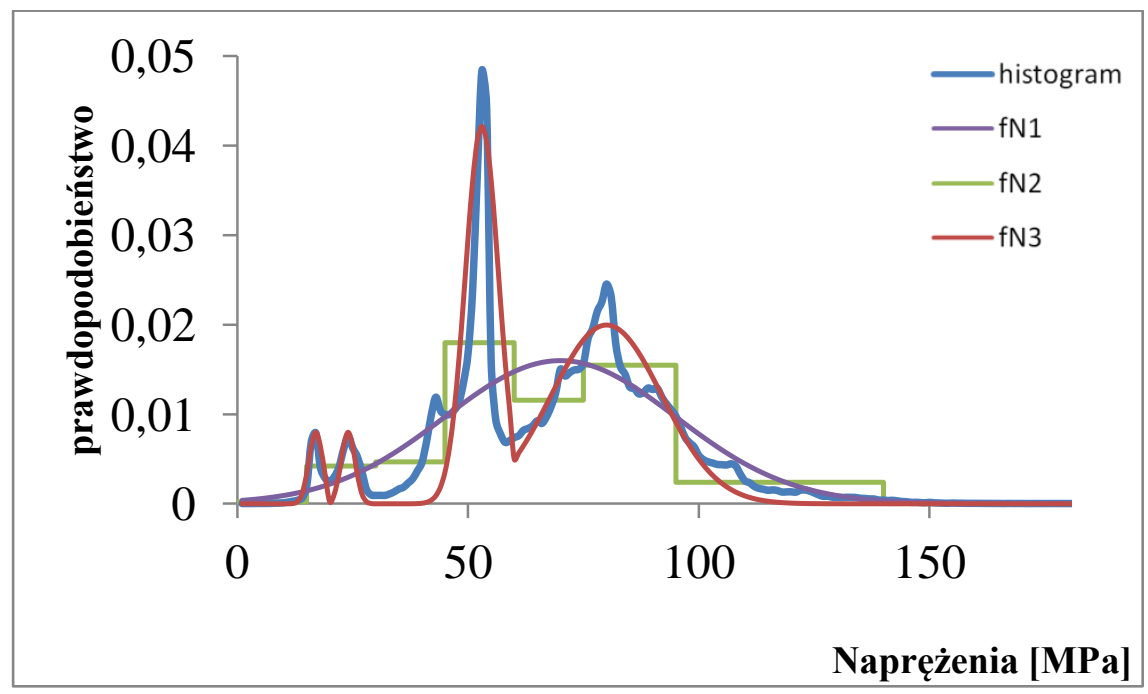

Rys. 3. Histogram naprężeń i jego aproksymacja funkcjami: $f_{N 1}, f_{N 2}, f_{N 3}$

\section{Wyniki}

Prawdopodobieństwo uszkodzenia punktu krytycznego struktury nośnej śmigłowca w modelu SSI wynosi $2,16 \cdot 10^{-8}$. Dla uogólnionego modelu Generalized StressStrength-Interference (GSSI) wyniki zależą od estymacji rozkładu naprężeń. Dla danych uzyskanych $\mathrm{z}$ modelu Markov'a prawdopodobieństwo uszkodzeń wyniosło: $9,19 \cdot 10^{-9}$ oraz 5,38・10-9 dla łańcucha Markov'a FCM $\left(f_{N 2}\right)$ oraz dla ukrytego modelu Markov'a HMM $\left(f_{N 3}\right)$.

Analiza modelu SST wykazała, iż prawdopodobieństwo uszkodzenia rzędu $1 \%$ będzie osiągnięte po 465000 cyklach w przypadku, gdy naprężenia mają rozkład normalny $\left(f_{N I}\right)$. Dla uogólnionego modelu SST uzyskano następującą liczbę cykli: 1290000 dla łańcucha Markov'a FCM $\left(f_{N 2}\right)$ oraz 1090000 dla ukrytego modelu Markov'a HMM $\left(f_{N 3}\right)$. 
Reliability analysis of helicopter's supportingstracture with SSI and SST models used Analiza niezawodnościowa struktury nośnej śmigłowca modelami SSI oraz SST

\section{Wnioski}

Model SSI (Stress-Strength-Interference) pozwala na obliczenie prawdopodobieństwa uszkodzenia struktury nośnej śmigłowca w punkcie krytycznym podczas jednokrotnego wzrostu wartości naprężenia. Nie znajduje on szerokiego zastosowania $\mathrm{w}$ lotnictwie gdzie naprężenia zmieniają się $\mathrm{w}$ czasie, może służyć jedynie jako ogólne przybliżenie.

$\mathrm{W}$ powyższych modelach niezawodnościowych nie został uwzględniony proces starzenia się elementu. Wzięcie pod uwagę tego zdarzenia spowoduje zmniejszenie liczby cykli możliwych do uszkodzenia danego punktu krytycznego.

Wyniki uzyskane z uogólnionych modeli SSI oraz SST mają podobne wartości w zależności od sposobu uzyskania funkcji prawdopodobieństwa dla naprężenia. Występują nieznaczne różnice w porównaniu do podstawowych modeli SSI bądź SST.

\section{Bibliografia}

[1] AIRO SOFTWARE: Projekt badawczy nr PBR 03/2000/z.

[2] C. Mattrand, J-M. Bourinet, D. Theret: Analysis of Fatigue Crack Growth under Random Load Sequences Derived from Military In-flight Load Data, 26th ICAF Symposium, Montreal, 2011.

[3] O. Cappe, E. Moulines, T. Ryden: Interference in Hidden Markov Models. Springer Series in Statistics, 2005.

[4] L. Rabiner: A tutorial on hidden Markov Models and Selected Applications in Speech Recognition, In: Readings in Speech Recognition 2011.

[5] Klimaszewski, S. i inni: Badania wytrzymałościowo-zmęczeniowe stali 30HGSNA. Sprawozdanie nr 35/31/2007, ITWL, Warszawa, 2007.

[6] Wrona, M. i inni: Wykonanie analizy trwałości zmęczeniowej dla głównych elementów siłowych konstrukcji kadłuba śmigłowca Mi-24, Sprawozdanie nr 114/31/2009, ITWL, Warszawa, 2009.

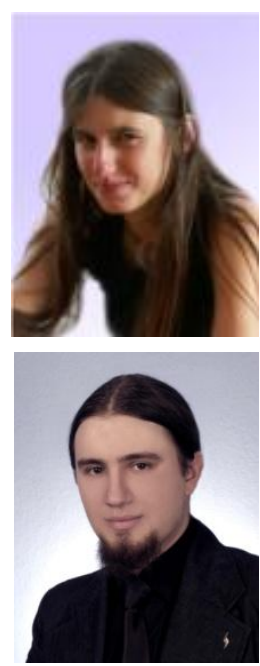

mgr inz. Marta Woch

Tomasz Bońkowski 


\title{
IMPACT OF INFRASTRUCTURE TYPE ON RELIABILITY OF RAILWAY TRANSPORTATION SYSTEM
}

\section{WPLYW RODZAJU INFRASTRUKTURY NA NIEZAWODNOŚĆ SYSTEMU TRANSPORTU SZYNOWEGO}

\author{
Franciszek J. Restel \\ Wroclaw University of Technology, Wroclaw, Poland, \\ e-mail: franciszek.restel@pwr.wroc.pl
}

\begin{abstract}
In this paper, the author's research work is focused on infrastructure impact on railway transportation system reliability. The aim of research described in the paper is to determine correlation between type (and age) of used infrastructure elements, and number of occurring failures. For this purpose, subsystem of infrastructure and associated with it events, were divided into main groups. Examples of groups are: track, train operation devices (related to operating control points or railway line), level crossings, etc. The second aspect is correlation between type of infrastructure and failure consequences. It is required from transportation that it is possible to achieve the right place at the right time in a safety way. Therefore, from the point of view of transportation process, which is the main goal of transportation system, the most significant failure consequences are delays. Moreover, speaking about reliability and safety of railway transportation system, the question arises what is the relation between number of trains and number of unwanted events?
\end{abstract}

Keywords: railway transportation system, infrastructure, reliability

Streszczenie: Celem badań opisanych $w$ artykule jest określenie korelacji pomiędzy typem (także wiekiem) użytkowanych elementów infrastruktury, a liczba wystęujacych zdarzeń. W tym celu podzielono infrastrukturę oraz zdarzenia z nia zwiazane na główne grupy. Przykładowymi grupami są: nawierzchnia, urzadzenia sterowania ruchem na posterunku ruchu, urzadzenia sterowania ruchem na linii, przejazdy kolejowe itp. Drugim aspektem jest korelacja pomiędzy typem infrastruktury a skutkami. Z punktu widzenia realizacji procesów transportowych, najważniejszym parametrem definiujacym skutki sq opóźnienia. Ponadto istotne jest pytanie, jaka jest zależność pomiędzy liczba pociagów a liczba zdarzeń.

Stowa kluczowe: transport pasażerski, strategia obstugiwania, system ekspertowy, opóźnienie czasowe 
Impact of infrastructure type on reliability of railway transportation system

Wplyw rodzaju infrastruktury na niezawodność systemu transportu szynowego

\section{Introduction}

Transportation processes may be disrupted as a result of various problems connected with:

- train failures,

- infrastructure failures (failures of rail, signalling etc.),

- random accidents occurrence (associated with environment).

Train failures can be classified into events related to train or passenger interactions and system failures resulting from vehicle unreliability. Vehicle reliability analysis has already been developed in researches for many decades.

On the other hand the infrastructure reliability has not been investigated and unfortunately, little attention has been given to this problem in reliability literature.

However, there has been no attempt to describe reliability of other components of the railway transportation system (passengers, crew, infrastructure). Due to lack of adequate literature sources, the paper is mainly based on case study of selected Polish railway lines.

For an analysed Polish region, events due to trains (including passengers and staff) participates by $34.91 \%$ in all failures. Unwanted events related to infrastructure participates by $51.36 \%$. The remaining $13.73 \%$ associated with environment of the system. The work ends up with summary and directions for further research.

\section{Research on railway reliability - state of art}

The rail system is investigated primarily at two levels of detail. The first is a detailed approach. Reliability and safety of specific components are researched.

The analysis of technical objects included in the infrastructure might be an example. The unit directly responsible for the safety of the railway - railway traffic control device are primarily analysed.

An important part in all the devices are those which work periodically, and the remaining time are standing by. That's where arises the problem of determining the time between failures, and linking it with real time. In this case, first determined is the operation time between failures. It sets out the daily amount of working hours and divided by 24 hours gives the coefficient used in determining failure rate. Using this coefficient it is possible to transfer to an absolute timeline [13]. In the case of traffic control devices Markov models are used for each technical object [13]. In [4] author used a Markov model to analyse the impact of different maintenance policies on the availability of the system.

Assessment of the reliability of rail vehicle components can also be carried out based on Markov processes, Reliability Block Diagrams [18] and Fault Trees [15]. Recently Markov processes have been used to model the degradation and damage of superstructure [6]. In addition to the studies based on mathematical models, the analysis on the operational data of failures have been performed. However, these analysis have been limited to statistical analysis and estimating parameters for future theoretical models [3], [16], [20], [23]. 
In addition to vehicles, discussed are issues of infrastructure and determine the relationship of the actions improving safety [2]. The issue is the optimal moment in terms of modernization of the infrastructure costs (damage, speed limits, the same upgrade). Solutions to this problem are obtained by Life Cycle Costs [17], where the decision algorithms for finding the support moment with minimal total cost are looked for [7], [9].

In [27] reliability of the processes in the analysis of the capacity of railway lines residually appears, where the task is to minimize the liquidation rate of delays, depending on the structure of the timetable. A similar issue is the capacity of railway junctions, in which the author examines the critical points of occupancy infrastructure in the context of route conflict.

In addition to the internal system's effects, the train delay causes derogations approved by the customer schedule. As a result of that event [8] carrier records the loses, which were estimated in [14]. More detailed is an analysis of the event impact treated as a primary failure and associated consequential failure (excluding the impact of motion) [24].

Punctuality evaluation model contained in [5] contains terms referring to the interaction between the rolling stock subsystem and the other subsystems, which in the context of a lack of knowledge on the subject greatly reduces the possibility of practical use.

The paper [19] presents a simulation model of the railway network. Two railway lines with a joint centre section were divided into equal sections. Each section can stay in one of six states describing degradation, where 0 is the only failure state. Intensities of transitions between states are constant. Degradation model was supplemented with possible route speed (nominal $100 \mathrm{~km} / \mathrm{h}$, reduced 80 or $60 \mathrm{~km} / \mathrm{h}$ ) to give the eighteen-state model to determine the daily delays on the network. Although taken into account the situation of motion, it was found that the scope is too narrow. The timetable, the number of main tracks, the impact of the station to operate trains, traffic control points, etc. were completely omitted.

For analysis of the risk of failures in the railway system, as in the case of other technical systems the event tree may be used. In [1] the analysis extends of the risk influencing factors. The issue is shown on the example of single-track lines, for which the top event is the collision of two trains coming from the opposite direction. The barriers designed to prevent the occurrence of top event were inventoried, and then a tree of events leading to barrier failure was made. Base events were assigned operating attributes to the risk factors. Supplies combined with a more general level (organizational factors). At the highest level of generality factors stemming from legal requirements were placed. Carrying out a study to determine risk factors and sequences show the relationships of cause and effect 
relationships that go beyond a simple Event Tree Analysis. In the present case it was shown that the most important factors that affect the risk are: human behaviour and operating conditions of the system.

In [29] was presented a traffic control system basing on local subsystem (stations operated by station inspector) and the subsystem of the regional supervisor. Conclusion is that, above all, human influence could be reduced by a parent verification of an operator actions system. However, similar to the standard signalling equipment it may occur a situation where one will need to bypass the system in order to enable the continuation of train run. In [26] was drown attention to the increased number of tasks that must be performed by station inspector for the occurrence of accidents, or just disruption. Then the convergence of load growth and cognitive behavioural influences the traffic safety (over $90 \%$ of accidents in the rail transport system is formed after taking over responsibility for human [21], and transportation disasters occur in about $80 \%$ of the fault of the man [10] ). The human factor is present in the whole system, not only in the direct running of trains by traffic control points [28].

In the railway transportation system are used many barriers to prevent threats [11]. Identifying of risk sources is described in more detail in [12], while [25] presents a method for the identification of barriers based on Fault Tree Analysis. The method is based on the so-called Swiss cheese model where the holes need to be imposed to the arrow passes (for the hazard to be). An hazard, which is the top event, is modelled by a typical Fault Tree with "if" and "or" gates. After completing the tree it is searched for the first gate or any of the branches, starting with the top event. An event which is above a given gate is connected directly or with a barrier, and is used to determine the barrier.

In conclusion, there are no models of intermediate accuracy, which takes into account the specific features of the structure resulting from the timetable and infrastructure features. The relationship between the characteristics of railway transport system and failure frequency as well as consequences of adverse events were not examined. Lack of knowledge in this area prevented the practical application of mathematical models of system reliability and safety of rail transport. In the next part the results of the first researches conducted in this area were shown.

\section{Dependencies in the system}

Before testing the effect of the most important factors, the most important features of the system' were inventoried, most of them are shown on a dependence map (Fig. 1). The map is shown in Figure 1. The relationships between parameters are shown in the relevant branches. A branch with the double-headed arrow shows a direct and strong impact on the characteristics of the preceding to which the branch is facing. A branch of a single full cave indicates a partial dependency. Branch of unfilled headed shows two-way influence. Parameters marked in red were used in the tests described later in this article. 


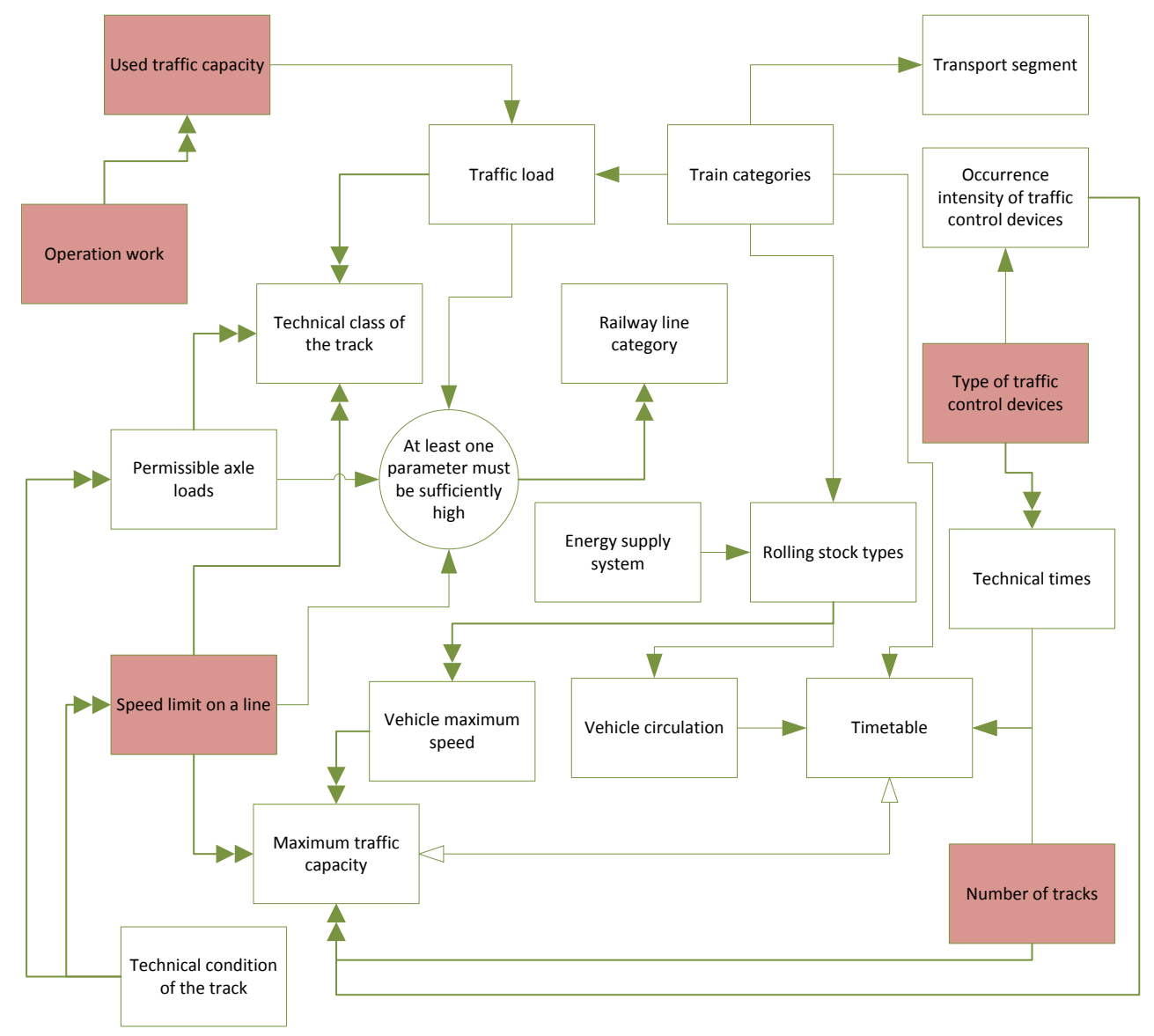

Fig. 1. Dependence map for the railway transport system.

\section{System failures and measure describes period between it}

Observations on the periodic operation time of level-crossing devices described in [13] also apply to other parts of the railway transportation system. Cycling working of level-crossing devices is forced by trains moving on railway line. As a result: surface is loaded, energy supplying system is working, traffic control devices and signalling devices are used, and finally the train is used. Of course, some of the equipment outside the periods of trains are running in idle mode (it's in standby mode) and still can be damaged then. The practice and the functioning of Railway suggest that failure of any device is detected only when trains pass, so when the device should be active.

It looks the same in case of the railway accidents, accidents with cars and pedestrians. In the extreme case in which there is no traffic on the railway line it is 
Impact of infrastructure type on reliability of railway transportation system

Wplyw rodzaju infrastruktury na niezawodność systemu transportu szynowego

not possible to train colliding with the car, deduct the man, train derailment or collision of two trains.

From the above, it is concluded that the absolute time does not sufficiently describe the periods between failures. Determining the daily working time and relate this to 24 hours, seems to be a good solution just for the simple analysis of reliability and safety of the individual devices, and only when the timetable is fixed. For the entire system or a fragment (e.g. railway line) another measure is needed to take into account seasonal factors in the form of passing trains. Such a measure is a operation work measured in train kilometres. It can be used for the whole system, selected railway lines, and even the selected type of trains and vehicles. The measure for a meaningful comparison of railway line reliabilities is proposed in [22].

The result of the above statements is a hypothesis that the best description of the size of the intervals between failures to analyse the reliability of railway transportation in the operational work is expressed in train-kilometres. In order to verify this hypothesis, were compared measures for intervals between system failures.

It was assumed that failures of rolling stock are independent of infrastructure. Such an assumption should be true, because in the railway there are no large differences in technical condition of infrastructure such as in the road transportation system. However, when the technical conditions goes bad, then the speed limit and permitted axle loads are reduced. This is done because it compensates the increased dynamic impact.

In order to verify the accuracy of the assumptions on the use of operational work as a more correct measure describing period between failures, the rolling stock subsystem is selected. There was also checked independence of rolling stock failures from infrastructure and on the other hand dependence from operational work.

For the same type of rolling stock, which is used on different railway lines at the same time period, there were prepared cumulated distribution functions of periods between failures expressed in time and in operational work. Furthermore, were also prepared cumulated distribution functions of failure consequences - delays.

It was assumed that confirmation of operational work application correctness will be given, when the operational work distributions are consistent and for the same case the time distributions are not consistent. The cumulated distribution functions of delays should also be consistent.

Interval between failures cumulated distribution functions (CDF) for rolling stock were done to three railway lines over which the same types of vehicles move (some of the same vehicles). 
Analysed lines differ mainly in the number of trains and operational work.

For each line it was drawn CDF of time between failure (Figure 2) and the CDF of operational work between failure (Figure 3).

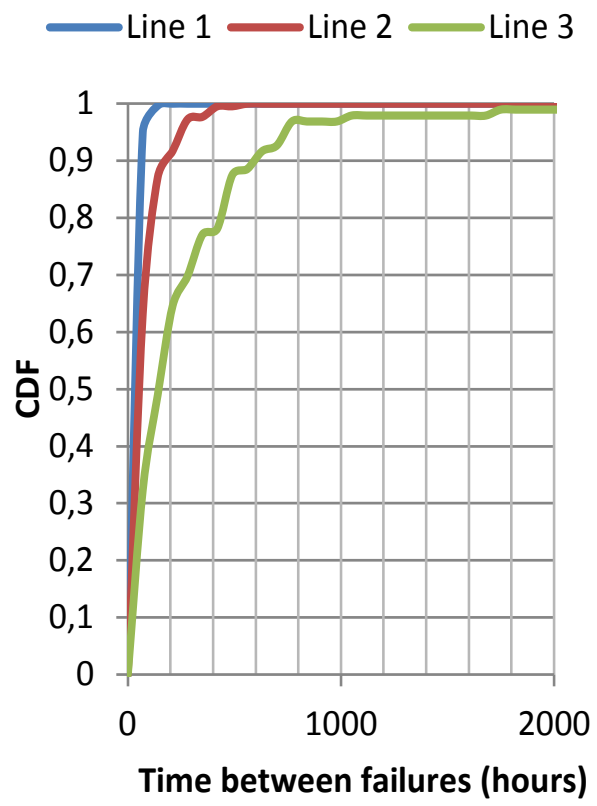

Fig. 2. Time between failures cumulated distribution function for rolling stock.
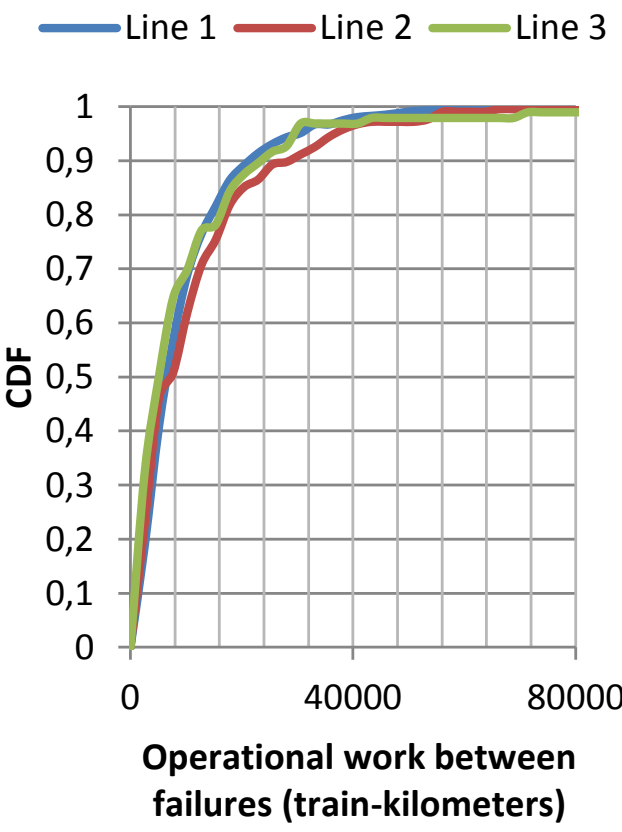

Fig. 3. Operational work between failures cumulated distribution function for rolling stock.

According to the suspicion there is compliance of CDF for periods measured in operational work (Figure 3). However, for the time between failures there is no convergence. As already stated, this is due to the different number of running trains. In addition to the visual convergence of the cumulated distribution function (CDF), Kolmogorov-Smirnov' test has been conducted. At the 0.05 significance level there is no reason to reject the hypothesis of operational work between failures CDF compliance (for rolling stock). Time between failure compliance hypothesis must be rejected.

Similarly was tested the compliance of delay CDF (Figure 4). Also in this case, at a significance level of 0.05 there is no basis for rejecting the hypothesis of compliance. The above analysis shows that the failures depends on the train operational work, and does not depend on the type of railway line, and depends slightly on time. 


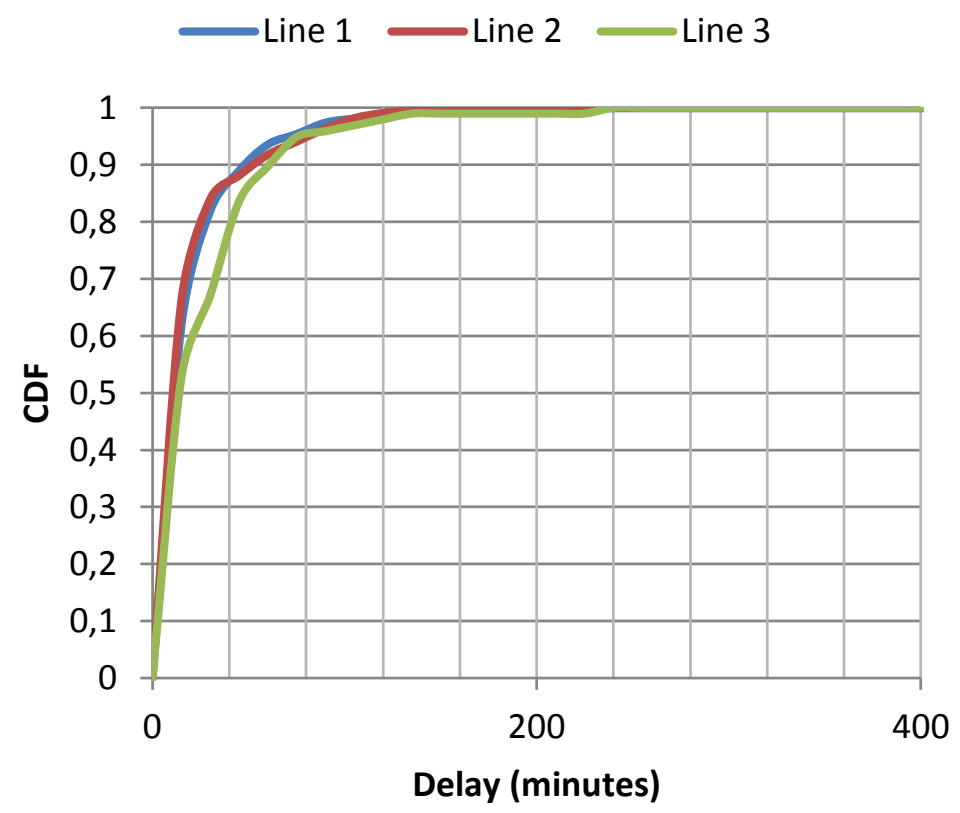

Fig. 4. Delay cumulated distribution function for rolling stock.

\section{Kinds of infrastructures and failures}

\section{Type of traffic control devices}

A similar experiment was carried out for operational work and time between failures to traffic control equipment. There was non-compliance of distribution of time between failures (Figure 4), and compliance to the operational work CDF to lines 2 and 3 (Figure 5), confirmed by the Kolmogorov-Smirnov' test at a significance level of 0.05 .

On railway lines 2 and 3 are running the same type of traffic control devices. Dominated by mechanical centralized (in some places relay devices), with three position block signalling. However, on line 1 after the modernization electronic devices has been installed, operated from a local control centre.

Traffic control devices have to have high quality standards in maintenance because they are directly responsible for the safety of train ride. For this reason, the device often pass technical inspection and preventive maintenance, after which they became as good as new devices. Given the high quality of repairs, even for the oldest devices it can be concluded that the lack of compliance for signalling equipment between lines 1 and 2, 3 is due to a difference in the types of devices. It is not, due to aging or degradation of devices. 


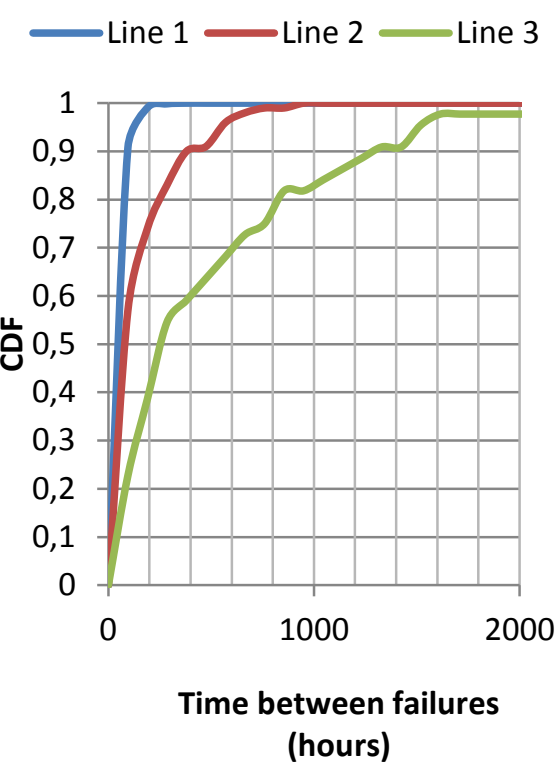

Fig. 5. Time between failures cumulated distribution function for traffic control devices.
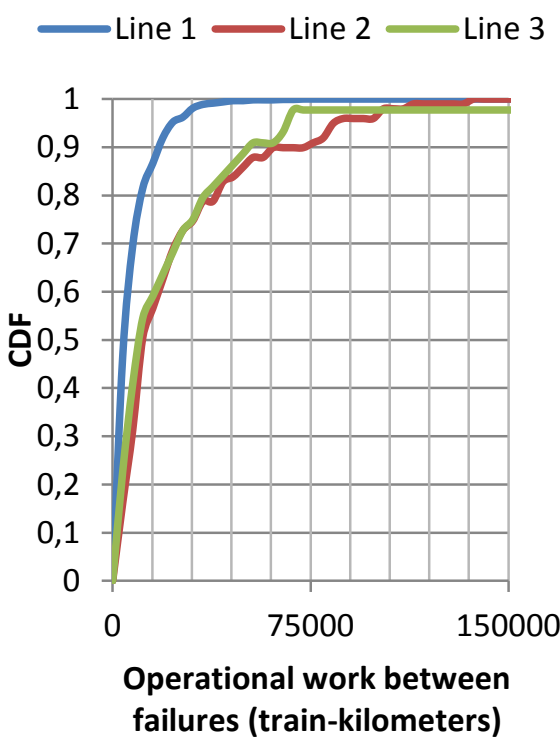

Fig. 6. Operational work between failures cumulated distribution function for traffic control devices.

From this it follows that due to the significance level of 0.05 Kolmogorov-Smirnov test, there is no reason to reject the hypothesis that the type of traffic control devices have an impact on failures. In addition, the theory has been confirmed by the Expression of periods between failures in train operational work (consistency of distribution lines 2 and 3).

Due to lack quantity and quality of data about delays resulting from traffic control devices, this aspect has not been tested.

\section{Track type and its technical condition}

In the case of track superstructure, maintenance policy is different. Due to the high investment costs associated with repair and modernization of railway lines, (e.g. the Polish Railways) it is used the optimization of the behaviour of maximum safety.

As a result of degradation the likelihood of superstructure failure is increasing, resulting in train derailment. To reduce risk in this case, with no major short-term funding, the values of two parameters decreasing: maximum speed and axle load. Due to limitations in the running of trains that may result from the reduction of axle load in practice speed is usually limited. The permitted speed in a specified moment can be used as an indicator of the technical condition of the track. The article presents only a preliminary study on the relationship between type of 
Impact of infrastructure type on reliability of railway transportation system Wplyw rodzaju infrastruktury na niezawodność systemu transportu szynowego

superstructure, condition and failure frequency. The reason for this is incomplete information on the technical condition of railway lines.

Comparing the technical condition of the line based on speed limits is not correct due to possible differences in the maximum speed depending on construction. Therefore, for the purposes of research is used a factor of actual speed limit to construction speed, as an indicator of railway line technical condition. On the basis of publicly available information, it was found that the rate coefficients for the scanning lines are characterized by the following relations:

where:

$$
\frac{V_{a 1}}{V_{c 1}} \approx 1>\frac{V_{a 2}}{V_{c 2}}>\frac{V_{a 3}}{V_{c 3}}
$$

Va1/Vc1 - actual speed limit/construction speed limit on line 1,

$\mathrm{Va} 2 / \mathrm{Vc} 2$ - actual speed limit/construction speed limit on line 2,

$\mathrm{Va} 3 / \mathrm{Vc} 3$ - actual speed limit/construction speed limit on line 3.

Indeed, line 1 has been recently modernized and is in the best condition. Line 2 is degraded to a greater extent (expert's opinion) in accordance with which the speed ratio is smaller. In the worst condition is line 3 , also the speed factor was the least. It should be noted that line 1 has a different type of track superstructure (noncontact-track with concrete sleepers along the entire length), which may have an effect on failure frequency.

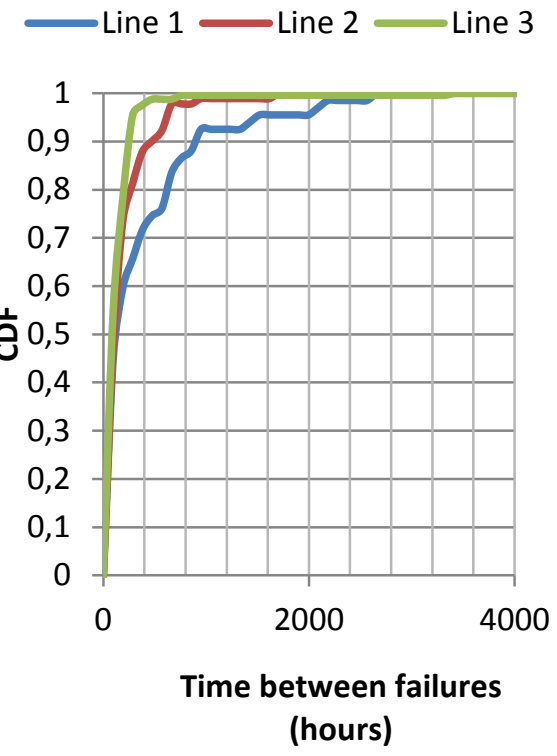

Fig. 7. Time between failures cumulated distribution function for track superstructure.

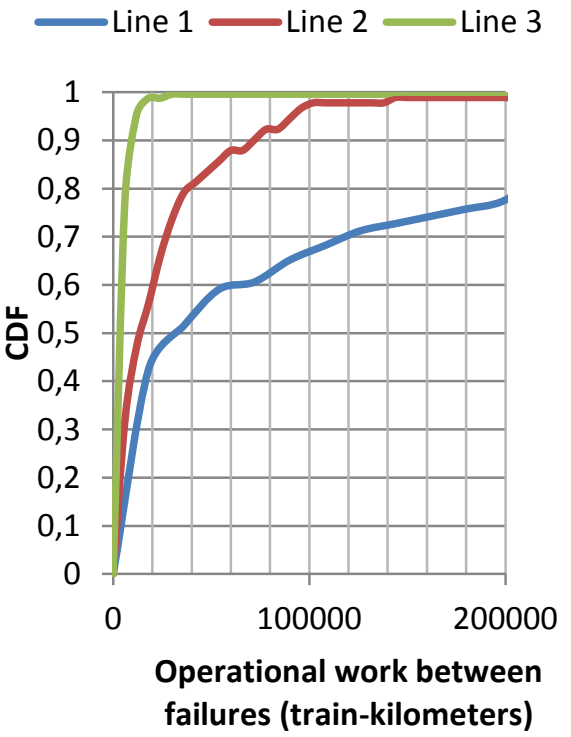

Fig. 8. Operational work between failures cumulated distribution function for track superstructure. 
Due to lack quantity and quality of data about delays resulting from track superstructure, this aspect has not been tested.

\section{Type of the energy supply system}

Energy equipment along a line supplies electricity to vehicles are regularly serviced. The maintenance policy is similar to the traffic control devices. Because of that after maintenance conditions of this devices are as good as new. During operation period are many elements replaced, such as transmission lines, copper wire, etc. However, the structure and the type of equipment do not change until a comprehensive modernization of the whole railway line. Energy devices periodically loaded by power consumption, when a train passes.

It follows that investigating consistence of CDF for the time between failure and operational work between failure can be inferred about impact of power equipment type on number of failures occurring. Moreover it can be concluded if these events are dependent on operational work or time.

Figure 10. shows CDF compliance in case of operational work between failures. Figure 9. shows lack of compatibility for CDF of time between failures. Graphical results confirmed Kolomogorow-Smirnov test at a significance level of 0.05. On this basis, it can be stated that the number of failures depends on operational work and does not depend on type of equipment.

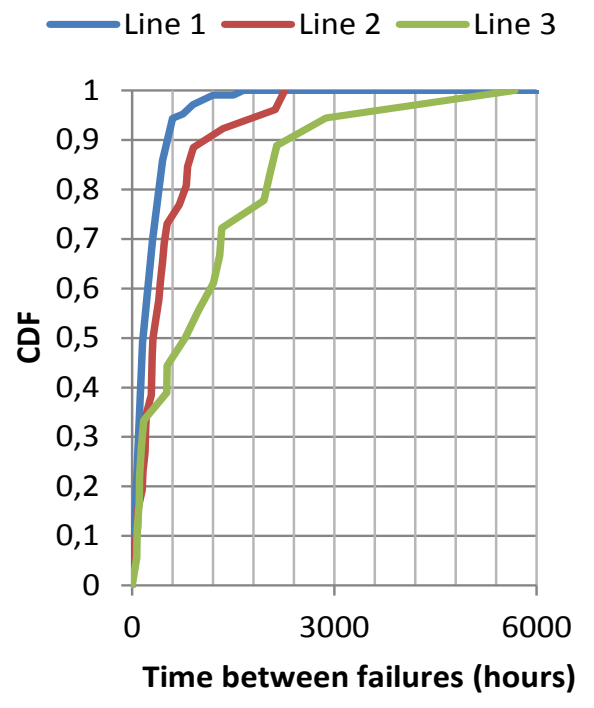

Fig. 9. Time between failures cumulated distribution function for energy supply system.

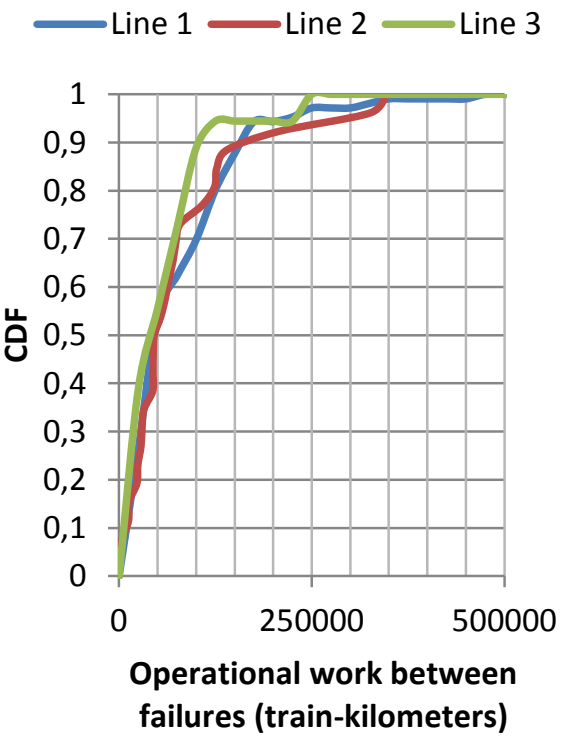

Fig. 10. Operational work between failures cumulated distribution function for energy supply system.

Due to lack of data about delays resulting from energy supply systems, this aspect has not been tested. 
Impact of infrastructure type on reliability of railway transportation system Wplyw rodzaju infrastruktury na niezawodność systemu transportu szynowego

\section{Unwanted events related to passengers}

Similar analyses were performed in the context of the passengers (for the same train categories). It turns out that the CDF of delays resulting from passenger events are consistent. On the other hand there is no compatibility between CDF of time between failures and also operational work between failures. It follows from this that both, time and operational work, does not directly affect the number of events. Presumably, the correct measure for the periods between events will be transport work measured in passenger-kilometres. No data on the number of passengers does not allow to verify this hypothesis at this moment.

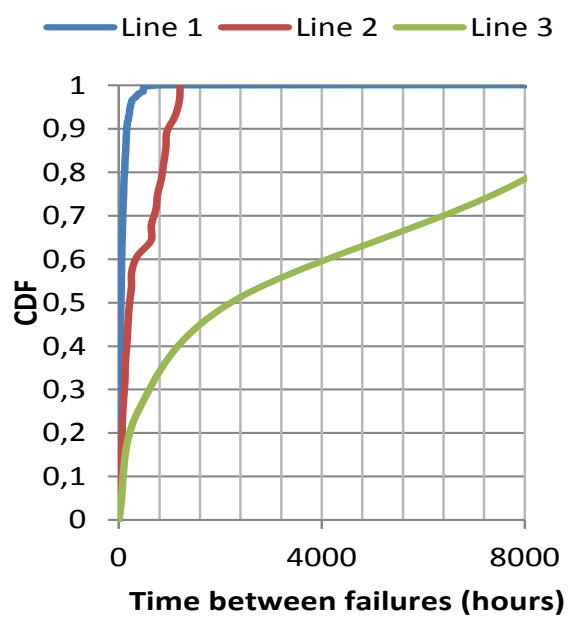

Fig. 11. Time between failures cumulated distribution function for passenger events.

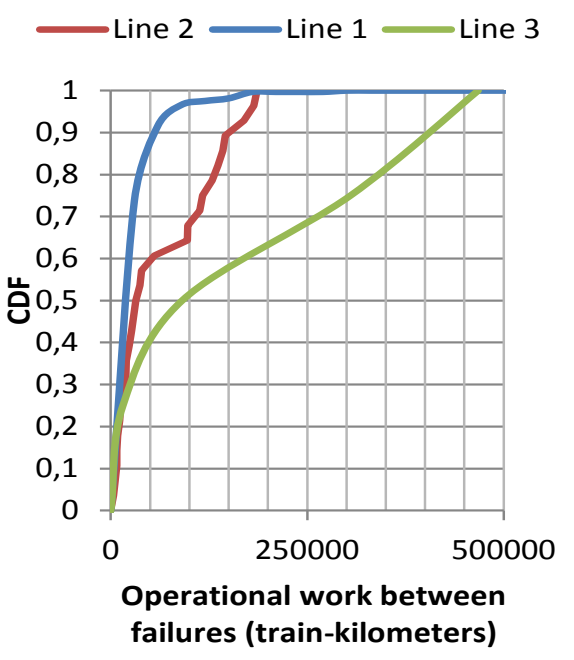

Fig. 12. Operational work between failures cumulated distribution function for passenger events.

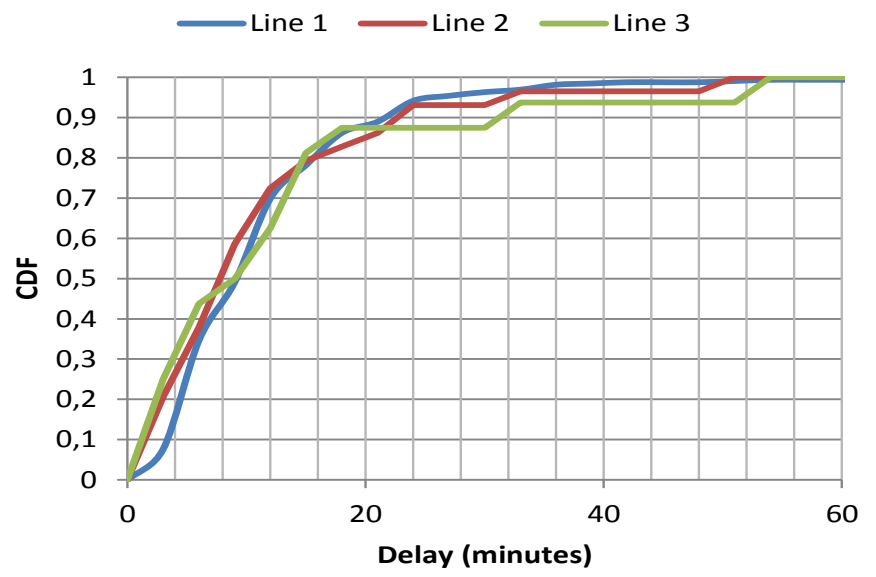

Fig. 13. Delay cumulated distribution function for passenger events. 


\section{Train traffic capacity and number of tracks - secondary delays}

Above was proven the impact of operational work on the occurrence of primary failures. Figure 13 shows the effect of traffic on the number of secondary delays. Traffic volume is represented by interval between trains (minimum technical gaps were included before).

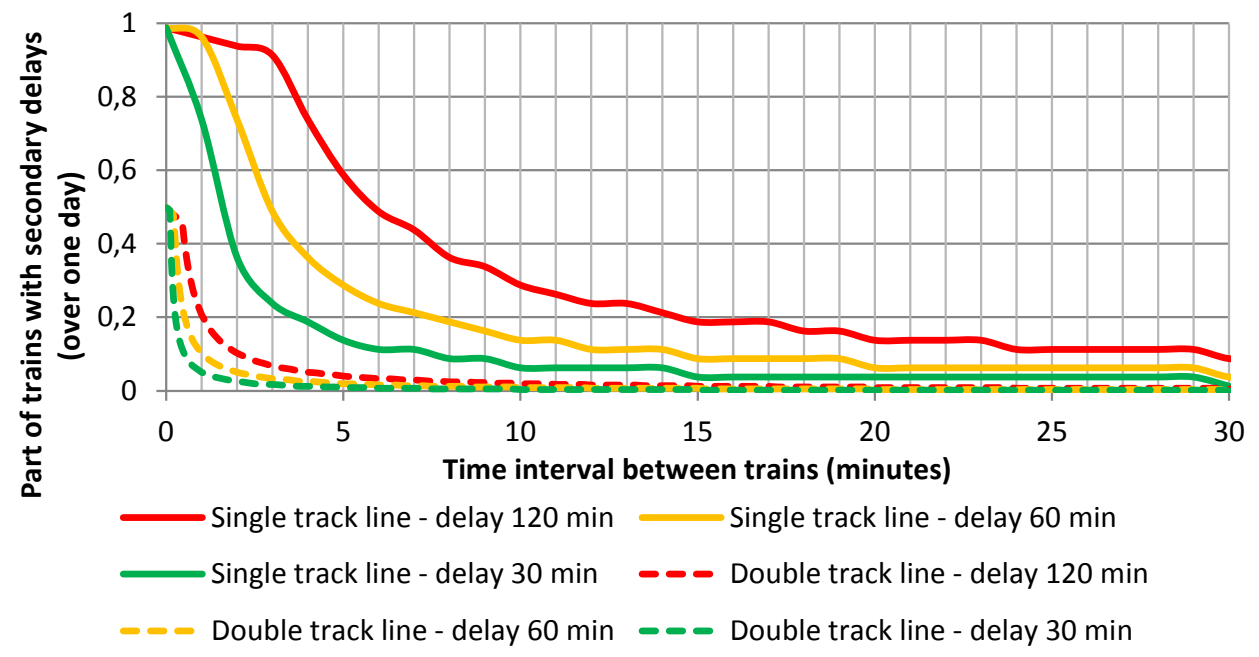

Fig. 14. Part of trains with secondary delays (over one day) in relation to time interval between trains and number of tracks.

The relationship between the part of secondary delayed trains (during the day) and the interval between trains is non-linear. Of course, also affected by the size of the initial delay.

The second aspect is the number of tracks. Visible are significant differences in the functions of the single-track and double-track line.

It follows that both, number of tracks and train traffic have impact on number of secondary delayed trains.

\section{Conclusions}

This article describes first results of research on impact of system parameters on the railway system reliability. It has been proven correlation between system failures (connected with rolling stock, signalling equipment, power equipment track superstructure) and train traffic (operational work). It was found that the rolling stock failures are independent of the railway line on which it moves.

Then it was found that the type of traffic control devices have an impact on number of failures in the system, and that this number depends on operational work on a railway line. 
Impact of infrastructure type on reliability of railway transportation system Wplyw rodzaju infrastruktury na niezawodność systemu transportu szynowego

It has been observed dependence of track superstructure age and condition on failures. This hypothesis has not been confirmed, however, the author supports this hypothesis and will it verify in the future.

No research on seasonality has been made, but for some sub-systems seasonality is noticeable. An example is rolling stock, which in winter damage more frequently than in summer.

Further studies will analyse events related to theft, vandalism, weather events and accidents. Data will be collected on delays and other measurable effects, and the analyses will be made, that currently cannot be done. In addition, impact of the technical conditions will be tested, especially track superstructure.

\section{References}

[1] Albrechtsen E., Hokstad P.: An analysis of barriers in train traffic using risk influencing factors. Safety and Reliability, Swets \& Zeitlinger, Lisse 2003

[2] Auer F., Schlöpp A.: Substanzermittlung der Oberbaukomponenten. ZEV Rail 9/2012

[3] Banek A., Roman Z., Kaniewski M.: Określenie trwałości i niezawodności sieci trakcyjnej. Prace Centralnego Ośrodka Badań i Rozwoju Techniki Kolejnictwa zeszyt 71, Wydawnictwa Komunikacji i Łączności, Warszawa 1978

[4] Brkić R., Adamović Z.: Research of Defects That Are Related with Reliability and Safety of Railway Transport System. Russian Journal of Nondestructive Testing, Volume 47/no. 6, 2011

[5] Chen H.-K.: New models for measuring the reliability performance of train service. Safety and Reliability, Swets \& Zeitlinger, Lisse 2003

[6] Dolven O.F., Lindqvist B.H., Hokstad P.R.: Statistical Modelling and Analysis of Failure and Inspection Data for a Railway Line. Proceedings of the European Safety and Reliability Conference, ESREL 2004

[7] Enzi M.: Der optimale Re-Investitionszeitpunkt für das Gleis unter dem Aspekt der Lebenszykluskosten. ZEV Rail 3/2012

[8] Gill A., Kadziński A., Gramza G.: Modele miar skutków kolejowych zdarzeń niepożądanych. XVIII Konferencja Naukowa Pojazdy Szynowe, Katowice-Ustroń 2008

[9] Hansemann F., Marschnig S.: Der Gleisprophet - ein Impuls zur Nachhaltigkeit. ZEV Rail 9/2012

[10] Kadziński A.: Wprowadzenie do zagadnień bezpieczeństwa systemów kolejowych pojazdów szynowych. XII Konferencja Naukowa Pojazdy Szynowe, PoznańRydzyna 1996 
[11] Kadziński A., Woźniak A.: O modelach kwantyfikacji zagrożeń bezpieczeństwa w transporcie kolejowym. XVI Konferencja Naukowa Pojazdy Szynowe, KrakówArłamów 2000

[12] Kadziński A., Gill A., Pruciak K.: Rozpoznawanie źródeł zagrożeń jako ważny element metod zarządzania ryzykiem w komunikacji tramwajowej. XIX Konferencja Naukowa Pojazdy Szynowe, Targanice k. Andrychowa 2010

[13] Krenželok T., Briš R., Klátil P., Stýskala V.: Reliability and safety of railway signalling and interlocking devices. Reliability, Risk and Safety: Theory and Applications, Tylor \& Francis Group, London 2010

[14] Kwaśnikowski J., Gill A., Gramza G.: Szacowanie stopnia strat ponoszonych przez przewoźników kolejowych w wyniku zdarzeń niepożądanych w ruchu kolejowym. XIX Konferencja Naukowa Pojazdy Szynowe, Targanice k. Andrychowa 2010

[15] Lisowski Z:: Modele niezawodności Boole’a i Markowa z uwzględnieniem wpływu człowieka w praktyce eksploatacyjnej pojazdów szynowych. Konferencja Naukowa Pojazdy Szynowe - 50 lat trakcji elektrycznej PKP, Wrocław 1986

[16] Marciniak J.: Zawodność eksploatacyjna elektrycznych maszyn trakcyjnych i badania przyczyn zawodności. VII Konferencja Naukowa Pojazdy Szynowe, Rydzyna 1988

[17] Marschnig S., Veit P.: Life Cycle Management in der Realität. ZEV Rail 9/2012

[18] Młyńczak M., Nowakowski T.: Ocena niezawodności odbieraka prądu. III Konferencja Naukowa Pojazdy Szynowe, Poznań 1979

[19] Podofillini L., Zio E., Marella M.: A multi-state Monte Carlo simulation model of a railway network system. Advances in Safety and Reliability, Tylor \& Francis Group, London 2005

[20] Pustelnik I., Świderski Z.: Analiza statystyczna uszkodzeń szyn w torach PKP za lata 1963 - 1965. Prace Centralnego Ośrodka Badań i Rozwoju Techniki Kolejnictwa - zeszyt 29, Wydawnictwa Komunikacji i Łączności, Warszawa 1968

[21] Renpenning F.: Reliability Prediction in Railway Signalling. Proceedings of the European Safety and Reliability Conference, ESREL 2004

[22] Restel F.J.: Measures of reliability and safety of rail transportation system. Advances in safety, reliability and risk management, CRC Press/Balkema 2012

[23] Roman Z.: Analiza uszkodzeń sieci trakcyjnej $3 \mathrm{kV}$ PKP. Prace Centralnego Ośrodka Badań i Rozwoju Techniki Kolejnictwa - zeszyt 45, Wydawnictwa Komunikacji i Łączności, Warszawa 1972

[24] Schöbel A., Maly T.: Operational fault states in railways. European Transportation Research Review, Springer published online 18.01.2012

[25] Schwartz S.: Identifikation von Sicherheitsbarrieren am Bahnübergang. ZEV Rail $1-2 / 2010$ 
Impact of infrastructure type on reliability of railway transportation system Wplyw rodzaju infrastruktury na niezawodność systemu transportu szynowego

[26] Sobków T.: Czynnik ludzki w bezpieczeństwie systemów kolejowych. XIX Konferencja Naukowa Pojazdy Szynowe, Targanice k. Andrychowa 2010

[27] Węgierski J.: Metody probabilistyczne w projektowaniu transportu szynowego. Wydawnictwa Komunikacji i Łączności, Warszawa 1971

[28] Wilson J.R., Norris B.J.: Human factors in support of a successful railway: a review. Cognition, Technology \& Work, Volume 8/no. 1, Springer 2005

[29] Wopiński A.: Z zagadnień niezawodności w systemach sterowania transportem kolejowym. Problemy Kolejnictwa zeszyt 68/69, Wydawnictwa Komunikacji i Łączności, Warszawa 1976

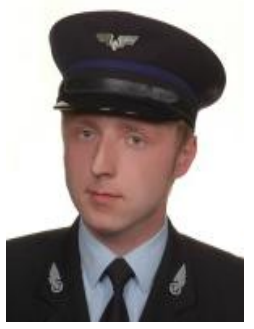

M.Sc. Franciszek J. Restel, Wroclaw University of Technology, Division of Logistics and Transportation Systems, received his M.Sc. in designing of transportation systems at Wroclaw University of Technology in Wroclaw, Poland in 2009. He is a PhD student at WUT. His research interests concern transportation systems, reliability and safety modelling. He is also interested in designing and operation of railway vehicles.

The project is co-financed by the European Union as part of the European Social Fund 


\title{
THE METHOD OF EVALUATION OF INITIAL AVAILABILITY IN THE TRANSPORT SYSTEM OF CITY BUSES
}

\section{METODA OCENY GOTOWOŚCI POCZATKOWEJ W SYSTEMIE AUTOBUSOWEGO TRANSPORTU MIEJSKIEGO}

\author{
Mirosław Szubartowski \\ Wloclawek College of Enterprise and Technology, Poland, \\ e-mail:biuro@karor.com.pl
}

\begin{abstract}
This paper presents the method of evaluation of initial availability of means of transport to carry out the assigned transport tasks. As an example of research object illustrating the presented deliberations, an actual city bus system from a selected urban agglomeration was used. In systems of this type, the technological objects (means of transport) have to initiate carrying out of the assigned transport tasks at assigned times, according to the adopted timetable. In order to assure the possibility to fulfill the transport tasks at assigned times, the so called time buffer is implemented in order for the necessary service processes to be carried out. In order to evaluate the availability of means of transport in the operational cycle of which the so called time buffer was implemented, it is convenient to use the characteristics describing initial availability of technological objects. Initial availability determines the probability of initiating (activating) the necessary number of technological objects in order to carry out the assigned tasks over a designated time period needed for their preparation and activation. The presented deliberation is illustrated by examples of the results of evaluation of initial availability in the actual tested transport system.
\end{abstract}

Keywords: transport system, initial availability, city buses

Streszczenie: $W$ pracy przedstawiono metode oceny gotowości początkowej środków transportu do realizacji przydzielonych zadań transportowych. Jako przykład obiektu badań, na którym zilustrowano przedstawione rozważania, wybrano rzeczywisty system eksploatacji autobusów miejskich $w$ wybranej aglomeracji miejskiej. $W$ systemach tego typu obiekty techniczne (środki transportu), $w$ wyznaczonych chwilach, zgodnie z przyjętym harmonogramem, musza przystapić do realizacji przydzielonych zadań przewozowych. W celu zapewnienia możliwości rozpoczęcia $w$ wyznaczonych chwilach zadań przewozowych, stosowany jest przedziat czasu, tzw. bufor czasowy, przeznaczony na realizacje niezbędnych procesów uzdatniania. Do oceny gotowości środków transportu, w których cyklu eksploatacyjnym zastosowano tzw. bufor czasowy, wygodnie jest zastosować charakterystyki opisujace gotowość poczatkowa obiektu technicznego. Gotowość poczatkowa określa prawdopodobieństwo przystapienia (uaktywnienia) wymaganej liczby obiektów technicznych do realizacji przydzielonych zadań, $w$ wyznaczonym przedziale czasu przeznaczonego na ich przygotowanie i uaktywnienie. Przedstawione rozważania zilustrowano przykładowymi wynikami oceny gotowości poczatkowej w badanym rzeczywistym systemie transportowym.

Stowa kluczowe: system transportowy, gotowość początkowa, autobusy miejskie 
The method of evaluation of initial availability in the transport system ...

Metoda oceny gotowości poczatkowej w systemie autobusowego transportu ...

\section{Introduction}

The concept of availability applies to such systems which are due to react fast in emergencies, that is: the army, police, emergency service, fire brigade, and transport systems as well. In general, the technical object availability (of an element or a system) can be defined as a feature which characterizes it in terms of its capability to achieve or maintain the availability state (enabling performance of the transport task) $[2,6,7]$.

The transport system consists of two main subsystems: logistics and executive. In the logistics subsystem, the processes carried out are supposed to assure task-based efficiency of the used technical objects. The task of the executive subsystem is to perform the assigned transport tasks over set routes, with a given frequency, according to a set schedule. In city bus transport systems, the system's task is executed by the executive subsystem, that consists of elementary subsystems type human being - technical object (e.g. the driver - the bus).

A proper accomplishment of the transport task is possible only if the required number of elementary subsystems is prepared to perform the assigned task in a given time. In order to assure the possibility to fulfill the transport tasks at assigned times, the so called time buffer is implemented in order for the necessary service processes to be carried out. Then, to evaluate the possibility of correct carrying out of the transport task, it is convenient to use the characteristics describing initial availability of technological objects. Initial availability determines the probability of initiating (activating) the necessary number of technological objects in order to carry out the assigned tasks over a designated time period $t_{g}$ (time reserve), needed for their preparation and activation. The article presents the method of evaluation of functional availability (when $t_{g}=0$ ) and initial availability (when $t_{g}>0$ ) of means of transport in the executive subsystem with a threshold structure $[1,3,4,5,6]$.

\section{The availability of executive subsystem with a threshold structure}

In complex systems of the use of means of transport, which include municipal bus transport systems, apart from basic technological objects designed for the carrying out of transport tasks there are also additional technological objects, the so called reserve objects. The task of a reserve object is replacing the basic object (continuing the task assigned to the basic object) in case of the carrying out of the task by the basic object becoming impossible, i.e. as a result of damage.

The object of investigation is the executive subsystem of the city bus transport system. The executive subsystem consists of two subsystems:

- working subsystem, that contains $n$ elementary components (basic technical objects), coupled with the row structure, essential for executing the task that are marked with $\mathrm{E}_{1} \div \mathrm{E}_{\mathrm{n}}$ symbols,

- reserve subsystem, that contains $k$ elementary components (reserve technical objects), marked with $E_{n+1} \div E_{n+k}$ symbols. 
When reserve objects are used, the structure which links the technological objects is a threshold structure of the " $n$ of $N$ " type, where:

- $N=n+k$ - the number of all technological objects used in the system,

- $n$ - the number of basic technological objects,

- $k$ - the number of reserve technological objects.

The executive subsystem with a threshold structure is schematically shown on the figure 1.

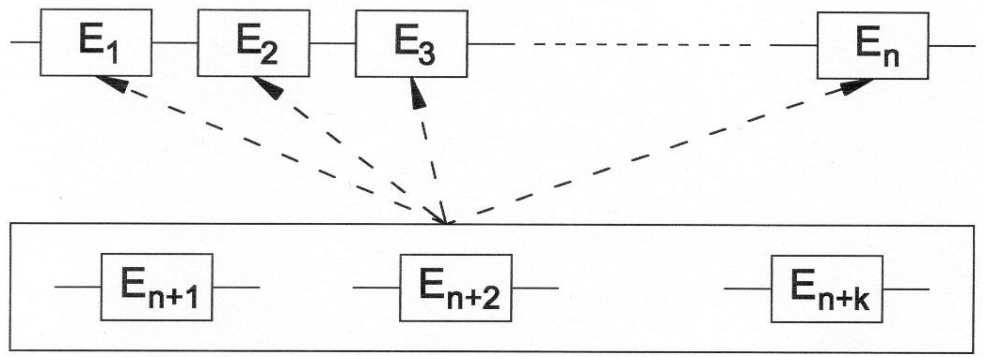

Fig. 1. The diagram of the executive subsystem with a threshold structure

A feature of threshold structure systems is the possibility of appropriate realization of an assigned task even when a given number of technological objects used in the system are not available for the carrying out of the task (nonoperational and/or unsupplied objects). The acceptable number of unavailable technological objects in the system may not be higher than $k$.

The availability of the utilization subsystem with threshold structure including $N$ technological objects, for which the required minimum number of objects available for the realization of the assigned transport task is equal to $n$, is described by the following relationship:

$$
G(t)=\sum_{j=n}^{n+k}\left(\begin{array}{c}
n+k \\
j
\end{array}\right)\left[p_{i}(t)\right]^{j}\left[q_{i}(t)\right]^{n+k-j},
$$

where:

$p_{i}(t)$ - availability of a single technological object (means of transport),

$q_{i}(t)$ - unavailability of a single technological object (means of transport).

Let's suppose, the executive subsystem operates in successive maintenance 24 hour cycles $c=1,2, \ldots$. In every single cycle we can distinguish four periods of operation and maintenance process:

$\mathrm{f}_{1}$ - the first phase (the technical object is awaiting, just to join the action), from $t_{0}$ moment to $t_{1}$ moment,

$\mathrm{f}_{2}-$ the second phase (the technical object is becoming active), from $t_{l}$ moment to $t_{2}$ moment,

$\mathrm{f}_{3}$ - the third phase (the technical object is on duty and can execute system's task), from $t_{2}$ moment to $t_{3}$ moment,

$\mathrm{f}_{4}$ - the fourth phase (service or repair) from $t_{3}$ moment to $t_{0}$ moment, in the logistic system. 
The method of evaluation of initial availability in the transport system ...

Metoda oceny gotowości poczatkowej w systemie autobusowego transportu ...

\section{The functional availability of executive subsystem}

The functional availability - probability, that the executive subsystem can be available to get the brand new task at the $t_{l}$ moment (i.e. at the end of the phase $f_{1}$ and with a time reserve $\left.t_{g}=0\right)$.

Every single element (technical object) of the executive subsystem after repair or service, while awaiting to join the duty action can be damaged on the parking ground, because of both poor weather conditions and poor conditions of the parking ground.

Let the variable $\left.e_{i}^{(1)}(t), i=1,2, \ldots, n+k, t \in<t_{0}, t_{1}\right)$, mean the condition of the $\mathrm{E}_{\mathrm{i}}$ element at the $t$ moment, while the phase $\mathrm{f}_{1}$ takes place:

$$
e_{i}^{(1)}(t)=\left\{\begin{array}{l}
1, \text { if } \mathrm{E}_{\mathrm{i}} \text { element is available at the } t \text { moment of the phase } \mathrm{f}_{1}, \\
0, \text { if } \mathrm{E}_{\mathrm{i}} \text { element is unavailable at the } t \text { moment of the phase } \mathrm{f}_{1} .
\end{array}\right.
$$

Then the (2) equation circumscribes the probability of the fact that the $\mathrm{E}_{\mathrm{i}}$ element is available at the $t$ moment, during the phase $\mathrm{f}_{1}$, since $t_{0}$ moment to $t_{1}$ moment:

$$
\left.p_{i}^{(1)}(t)=P\left(e_{i}^{(1)}(t)=1\right), \quad i=1,2, \ldots, n+k, \quad t \in<t_{0}, t_{1}\right) .
$$

Let's suppose, that values of those probabilities at the $t_{l}$ moment (i.e. at the end of the phase $\mathrm{f}_{1}$ ) are constant, and circumscribed with the (3) equation:

$$
p_{i}^{(1)}\left(t_{1}\right)=p_{i}^{(1)}, 0 \leq p_{i}^{(1)} \leq 1, i=1,2, \ldots, n+k .
$$

Because, according to the assumption, system's elements can be damaged independently, the functional availability, calculated for the executive subsystem during the phase $f_{1}$ can be described with the following (4) equation:

$$
\left.G^{(1)}(t)=\sum_{j=n}^{n+k}\left(\begin{array}{c}
n+k \\
j
\end{array}\right)\left[p_{i}^{(1)}(t)\right]^{j}\left[q_{i}^{(1)}(t)\right]^{n+k-j}, t \in<t_{0}, t_{1}\right),
$$

where:

$q_{i}^{(1)}(t)$ - probability of fact, that the $\mathrm{E}_{\mathrm{i}}$ element can be unavailable at the $t$ moment, during the phase $f_{1}$; the probability is described with the (5) equation:

$$
\left.q_{i}^{(1)}(t)=1-p_{i}^{(1)}(t)=P\left(e_{i}^{(1)}(t)=0\right), i=1,2, \ldots, n+k, t \in<t_{0}, t_{1}\right) .
$$

The functional availability of executive subsystem at the $t_{l}$ moment (i.e. at the end of the $f_{1}$ phase) can be circumscribed with the following (6) equation:

$$
G^{(1)}=G^{(1)}\left(t_{1}\right)=\sum_{j=n}^{n+k}\left(\begin{array}{c}
n+k \\
j
\end{array}\right)\left[p_{i}^{(1)}\right]^{j}\left[q_{i}^{(1)}\right]^{n+k-j},
$$


where:

$q_{i}^{(1)}$ - probability of fact, that the $\mathrm{E}_{\mathrm{i}}$ element is unavailability at the $t_{1}$ moment, at the end of the phase $f_{1}$; the probability is described with the (7) equation:

$$
q_{i}^{(1)}=1-p_{i}^{(1)}=P\left(e_{i}^{(1)}\left(t_{1}\right)=0\right) .
$$

\section{The initial availability of executive subsystem}

The initial availability - probability, that the executive subsystem can be available to get the brand new task at the $t_{2}$ moment (i.e. at the end of the phase $f_{2}$ and with a time reserve $t_{g}>0$ ).

During the phase $f_{2}$, the element of executive subsystem (technical object) is stimulated to action (executing the task) by the service team. Every single element is checked and stimulated to action. However, it is possible that some elements can't be included in action, because they have been damaged during the stopover on the parking ground, while awaiting to join the duty.

Let the variable $\left.e_{i}^{(2)}(t), i=1,2, \ldots, n+k, t \in<t_{1}, t_{2}\right)$, mean the condition of the $\mathrm{E}_{\mathrm{i}}$ element at the $t$ moment, while the phase $\mathrm{f}_{2}$ takes place:

$$
e_{i}^{(2)}(t)=\left\{\begin{array}{l}
1, \text { if } \mathrm{E}_{\mathrm{i}} \text { element is available at the } t \text { moment of the phase } \mathrm{f}_{2} \\
0, \text { if } \mathrm{E}_{\mathrm{i}} \text { element is unavailable at the } t \text { moment of the phase } \mathrm{f}_{2}
\end{array}\right.
$$

Then the (8) equation circumscribes the probability of the fact that the $E_{i}$ element has been correctly stimulated to action at the $t$ moment during the phase $\mathrm{f}_{2}$, since $t_{1}$ moment to $t_{2}$ moment. At the same moment the $E_{i}$ element is available to start executing the task:

$$
\left.p_{i}^{(2)}(t)=P\left(e_{i}^{(2)}(t)=1\right), \quad i=1,2, \ldots, n+k, \quad t \in<t_{1}, t_{2}\right) .
$$

Let's suppose, that values of those probabilities at the $t_{2}$ moment (i.e. at the end of the phase $f_{2}$ ) are constant, and circumscribed with the (9) equation:

$$
p_{i}^{(2)}\left(t_{2}\right)=p_{i}^{(2)}, 0 \leq p_{i}^{(2)} \leq 1, i=1,2, \ldots, n+k .
$$

Because, according to the assumption, system's elements can be damaged independently, the initial availability, calculated for the executive subsystem during the phase $f_{2}$ can be described with the following (10) equation: 
The method of evaluation of initial availability in the transport system ...

Metoda oceny gotowości poczatkowej w systemie autobusowego transportu ...

$$
\left.G^{(2)}(t)=\sum_{j=n}^{n+k}\left(\begin{array}{c}
n+k \\
j
\end{array}\right)\left[p_{i}^{(2)}(t)\right]^{j}\left[q_{i}^{(2)}(t)\right]^{n+k-j}, t \in<t_{1}, t_{2}\right),
$$

where:

$q_{i}^{(2)}(t)$ - probability of fact, that the $\mathrm{E}_{\mathrm{i}}$ element can be unavailable at the $t$ moment, during the phase $\mathrm{f}_{2}$; the probability is described with the (11) equation:

$$
\left.q_{i}^{(2)}(t)=1-p_{i}^{(2)}(t)=P\left(e_{i}^{(2)}(t)=0\right), i=1,2, \ldots, n+k, t \in<t_{1}, t_{2}\right) .
$$

The initial availability of executive subsystem at the $t_{2}$ moment (i.e. at the end of the $f_{2}$ phase) can be circumscribed with the following (12) equation:

$$
G^{(2)}=G^{(2)}\left(t_{2}\right)=\sum_{j=n}^{n+k}\left(\begin{array}{c}
n+k \\
j
\end{array}\right)\left[p_{i}^{(2)}\right]^{j}\left[q_{i}^{(2)}\right]^{n+k-j},
$$

where:

$q_{i}^{(2)}$ - probability of fact, that the $\mathrm{E}_{\mathrm{i}}$ element is unavailability at the $t_{2}$ moment, at the end of the phase $f_{2}$; the probability is described with the (13) equation:

$$
q_{i}^{(2)}=1-p_{i}^{(2)}=P\left(e_{i}^{(2)}\left(t_{2}\right)=0\right) .
$$

\section{Test results}

Presented below are selected results of the evaluation of availability of the executive subsystem in the transport system of city buses. The presented results exemplify changes in the values of the availability of the executive subsystem $G^{(f)}$ for the carrying out of the assigned transport task in the availability function $p_{i}^{(f)}$ of a single technological object (means of transport) while the number of all technological objects used within the system amounts to $N=180$. The size of the transport task is defined by the required number $n=160$ of technological objects (means of transport) necessary for appropriate carrying out of the task. The availability of the executive subsystem was determined for two cases:

- When reserve time is $t_{g}=0$ - (functional availability),

- When reserve time is $t_{g}=0,5 \mathrm{~h}$ - (initial availability).

Data necessary to determine the characteristics defining the availability of the executive subsystem were obtained on the basis of the carried out operational tests and source documentation used in the actual tested transport system of city buses. The obtained results were presented in figure 1 . 


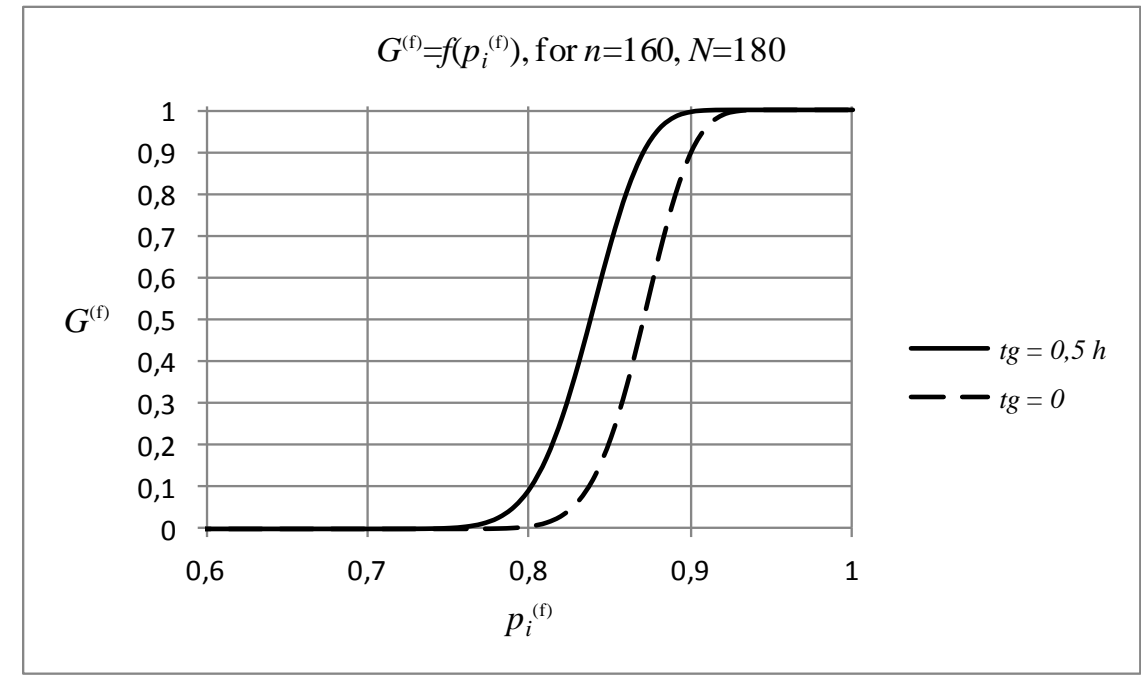

Fig. 2 Availability of the executive subsystem in availability function of a single technological object

\section{Summary}

The method presented in this article makes it possible to evaluate the availability of the executive subsystem in means of transport operation system in which technological objects are linked by threshold structure. This type of structure is known for using the so=called reserve objects, replacing primary objects in case of damage.

The use of reserve time $t_{g}>0$ in actual transport system of city buses makes it possible to increase the initial availability of the executive subsystem for a given number of technological objects operational in the system and a given availability of a single technological object. In the tested operation system the time reserve $t_{g}$ is used in order to carry out the processes of conditioning on a small scale and is connected with repairs carried out at the depot site as well as en route by specialized units of emergency service.

At further stages of the conducted research, in order to evaluate the influence of the parameters of the carried out operation process of means of transport (city buses) a mathematical model of the process will be prepared.

\section{References}

[1] Bobrowski D.: Modele i metody matematyczne teorii niezawodności w przykładach i zadaniach, WNT, Warszawa, 1985.

[2] Jaźwiński J. Grabski F.: Niektóre problemy modelowania systemów transportowych, Instytut Technologii Eksploatacji, Warszawa-Radom, 2003.

[3] Praca zbiorowa pod redakcją J. Migdalskiego: Inżynieria niezawodności Poradnik, ZETOM, Warszawa, 1992. 
The method of evaluation of initial availability in the transport system ...

Metoda oceny gotowości poczatkowej w systemie autobusowego transportu ...

[4] Woropay M. Dulcet E. Szubartowski M.: Mathematical model for analysis of the reliability of a task performing subsystem of municipal transport system, ASCIM 2000 Proceedings of the $2^{\text {nd }}$ Asia-Pacific Conference on Systems Integrity and Maintenance, Chiny, 2000.

[5] Woropay M. Szubartowski M.: Matematyczny model analizy niezawodności systemu wykonawczego transportu miejskiego, Informator Instytutu Technicznego Wojsk Lotniczych, Materiały Konwersatorium Problemy Inżynierii Eksploatacji, Warszawa, 2000.

[6] Woropay M. Szubartowski M. Migawa K.: Model oceny i kształtowania gotowości operacyjnej podsystemu wykonawczego w systemie transportowym, Instytut Technologii Eksploatacji, Radom, 2003.

[7] Żurek J.: Problemy gotowości techniki lotniczej, Rozdział 13, Praca zbiorowa: Problemy badań i eksploatacji techniki lotniczej, Tom 2, Wydawnictwo ITWL, Warszawa, 1993.

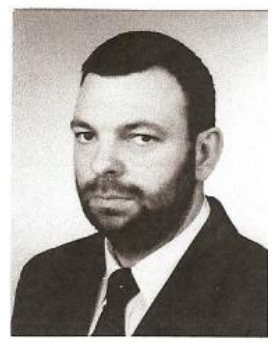

Ph.D Mirostaw Szubartowski works in the College of Enterprise and Technology in Wtoctawek, Poland. In his scientific research he concentrates on modeling of complex technological object operation systems as well as processes carried out therein. He has authored and co-authored several dozen scientific publications in the areas of reliability, availability and safety of transport system operation. 


\title{
FLIGHT TESTS OF THE UNMANNED HELICOPTER ILX-27 - SOME SELECTED ISSUES
}

\section{ZAGADNIENIA PRÓB W LOCIE BEZZALOGOWEGO ŚMIGLOWCA ILX-27}

\author{
Jarosław Hajduk, Ryszard Sabak \\ Instytut Techniczny Wojsk Lotniczych \\ e-mail:jaroslaw.hajduk@itwl.pl; ryszard.sabak@itwl.pl
}

\begin{abstract}
The unmanned helicopter ILX-27 has been designed and developed under the NCBR (in English, NCRD - National Center for Research and Development) project on the "Unmanned helicopter - a special-purpose aerobot" carried out by the Institute of Aviation (IL) and the Air Force Institute of Technology (ITWL), both in Warsaw, and the Military Aviation Works No. 1 J.S.C. in Łódź (WZL Łódź). The helicopter in question is a design initiated and developed solely as an unmanned vehicle in the weight category (MTOW) of $1100 \mathrm{~kg}$. It is the outcome of a complex approach to issues of the helicopter's structure and aerodynamics, and those of controlling it at different flight phases. From the very beginning, flight tests of this unmanned helicopter have been carried out under the remote-control mode of operation. The paper has been intended to present the outcomes of some selected stages of the project, i.e. the study and tests of groundcontrol components, and the flight tests.
\end{abstract}

Keywords: $\boldsymbol{U A V}$

Streszczenie: Bezzałogowy śmigłowiec ILX-27 zostat opracowany $w$ ramach projektu NCBiR pt. „Bezzałogowy śmigłowiec - robot do zadań specjalnych”. Śmigłowiec zostat zaprojektowany od podstaw jako statek bezzałogowy w klasie masowej - 1000kg. Jest wynikiem kompleksowego podejścia do zagadnień wiażacych zasady aerodynamiki w różnych stanach lotu z uwzględnieniem wptywu strumienia śmigłowego oraz indywidualnych cech uktadu sterowania automatycznego. Jest to nowa konstrukcja. W artykule przedstawiono wyniki ostatnich etapów projektu: badań i prób elementów sterowania na stanowisku naziemnym oraz prób w locie podczas zawisu.

Stowa kluczowe: $B S P$, 
Flight tests of the unmanned helicopter ILX-27 - some selected issues Zagadnienia prób w locie bezzałogowego śmigłowca ILX-27

\section{Wprowadzenie}

W ostatnich latach nastapił gwałtowny rozwój bezzałogowych statków powietrznych (BSP). Najczęściej i najspektakularniej są one wykorzystywane w czasie działań wojskowych. Wśród bezzałogowych statków powietrznych możemy wyróżnić dwie grupy: najbardziej rozpowszechnioną - samoloty oraz coraz bardziej zwiększającą swoje możliwości - śmigłowce. Jedną z możliwych klasyfikacji bezzałogowych statków powietrznych ze względu na zasięg działania, pułap i długotrwałość lotu przedstawiono w tabeli 1.

Tabela 1 klasyfikacja bezzałogowych statków powietrznych

\begin{tabular}{|c|c|c|c|c|}
\hline Kategoria & $\begin{array}{l}\text { Nazwa } \\
\text { skrócona }\end{array}$ & $\begin{array}{l}\text { Zasięg } \\
{[\mathbf{k m}]}\end{array}$ & $\begin{array}{l}\text { Pulap } \\
{[\mathrm{km}]}\end{array}$ & $\begin{array}{c}\text { Czas lotu } \\
{[\mathrm{h}]}\end{array}$ \\
\hline \multicolumn{5}{|c|}{ UAV SZCZEBLA TAKTYCZNEGO I OPERACYJNEGO } \\
\hline Mikro & $\mu$ & $<10$ & 0,25 & 1 \\
\hline Mini & MINI & $<10$ & 0,35 & $<2$ \\
\hline Bliskiego zasięgu & $\mathbf{C R}$ & $10 \div 30$ & 3 & $2 \div 4$ \\
\hline Krótkiego (małego) zasięgu & SR & $30 \div 70$ & 3 & $3 \div 6$ \\
\hline Średniego zasięgu & MR & $70 \div 200$ & $3 \div 5$ & $6 \div 10$ \\
\hline $\begin{array}{l}\begin{array}{l}\text { Sredniego zasięgu i } \\
\text { długotrwałości lotu }\end{array} \\
\end{array}$ & MRE & do 500 & $5 \div 8$ & $10 \div 18$ \\
\hline Niskiego pułapu i głębokiego przenikania & LADP & $>250$ & $0,05 \div 8$ & $0,5 \div 1$ \\
\hline $\begin{array}{|lll|}\text { Niskiego pułapu i wydłużonej } \\
\text { długotrwałości lotu }\end{array}$ & LAE & $>500$ & 3 & $>24$ \\
\hline \begin{tabular}{|l} 
Sredniego pułapu i dużej długotrwałości \\
lotu
\end{tabular} & MALE & $>500$ & $5 \div 8$ & $24 \div 48$ \\
\hline \multicolumn{5}{|c|}{ UAV SZCZEBLA STRATEGICZNEGO } \\
\hline $\begin{array}{l}\text { Wysokiego pułapu i dużej długotrwałości } \\
\text { lotu }\end{array}$ & HALE & $>1000$ & $15 \div 20$ & $24 \div 48$ \\
\hline $\begin{array}{|lll|}\begin{array}{l}\text { Samolot bezpilotowy } \\
\text { bojowym }\end{array} & \text { o } & \text { zastosowaniu } \\
\end{array}$ & UCAV & $>400$ & $<20$ & 2 \\
\hline \multicolumn{5}{|c|}{\begin{tabular}{|c|} 
UAV SPECJALNEGO PRZEZNACZENIA \\
\end{tabular}} \\
\hline \begin{tabular}{|l|l|} 
Bezpilotowe środki atakujące & \\
\end{tabular} & LETH & $>300$ & $3 \div 4$ & $3 \div 4$ \\
\hline Wystrzeliwane z napędem rakietowym & DEC & $0 \div 500$ & $0,05 \div 5$ & $<4$ \\
\hline
\end{tabular}

Do głównych zadań realizowanych przez bezzałogowe statki powietrzne można zaliczyć:

- rozpoznanie;

- obserwację;

- wykrywanie;

- lokalizację;

- ocenę zniszczeń;

- wsparcie misji poszukiwawczo-ratowniczych;

- śledzenie pojazdów i jednostek morskich;

- analizę skażeń;

- wykonywanie zdjęć lotniczych. 


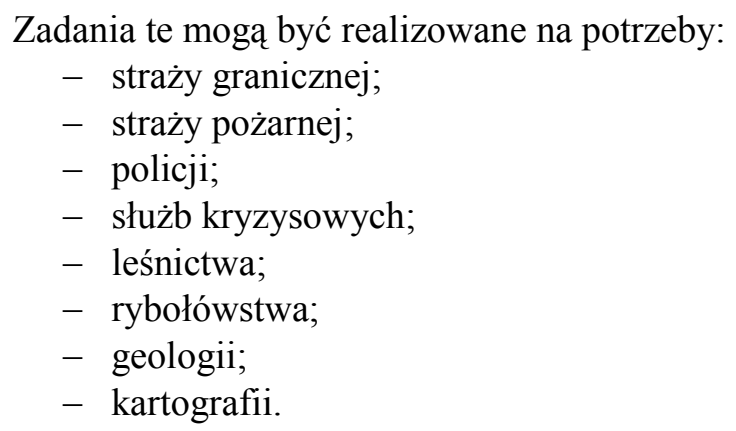

Jednym $\mathrm{z}$ istotnych kierunków prac zarówno w Instytucie Lotnictwa jak i w Instytucie Technicznym Wojsk Lotniczych od wielu lat jest rozwój systemów bezzałogowych statków powietrznych. W ostatnich latach w ramach projektu pt. „Bezzałogowy śmigłowiec - robot do zadań specjalnych” finansowanego przez Narodowe Centrum Badań i Rozwoju, opracowano bezzałogowy śmigłowiec ILX-27. Śmigłowiec został zaprojektowany od podstaw jako statek bezzałogowy w klasie masowej - 1000kg. Powstał w wyniku kompleksowego podejścia do zagadnień wiążących zasady aerodynamiki $w$ różnych stanach lotu z uwzględnieniem wpływu strumienia śmigłowego oraz indywidualnych cech układu sterowania automatycznego.

$$
\begin{array}{ll}
\text { Przewidywane parametry śmigłowca: } \\
\text { - zasięg } & -400 \mathrm{~km} \\
- \text { pułap } & -4000 \mathrm{~m} \\
- \text { udźwig } & -300 \mathrm{~kg} \\
- \text { prędkość maksymalna } & -215 \mathrm{~km} / \mathrm{h}
\end{array}
$$

\section{Stan wyjściowy projektu}

W projekcie większość głównych zespołów śmigłowca została zaprojektowana „od podstaw" (głowica wirnika głównego, łopaty wirnika głównego, tarcza sterująca, struktura nośna, przekładnia główna, struktura centralna, struktura ogona, wirnik ogonowy, podwozie, elementy systemu sterowania). Żaden w wymienionych głównych zespołów śmigłowca ILX-27 nie był fragmentem śmigłowca załogowego, a więc nie był wcześniej poddany badaniom w locie. Dlatego też zostały one wszechstronnie przebadane stanowiskowo, a kompletny śmigłowiec przeszedł cykl badań naziemnych (rys. 1). Jednak to zagadnienie realizacja oblotu i prób w locie był jednym z najważniejszych punktów projektu.

Sam prototypowy śmigłowiec od początku projektu nie był przewidziany do instalacji kabiny pilota czy choćby „prowizorycznego" miejsca dla pilota i standardowych organów sterowania, jak często ma to miejsce w przypadku innych projektów UAV w tej klasie masowej (zarówno samolotów jak i śmigłowców). Konsekwencją tego stanu była konieczność przygotowania 
Flight tests of the unmanned helicopter ILX-27 - some selected issues Zagadnienia prób w locie bezzałogowego śmigłowca ILX-27

prototypu, naziemnej stacji sterowania oraz przeszkolenie członków zespołu do realizacji oblotu i prób w locie w trybie zdalnego sterowania.

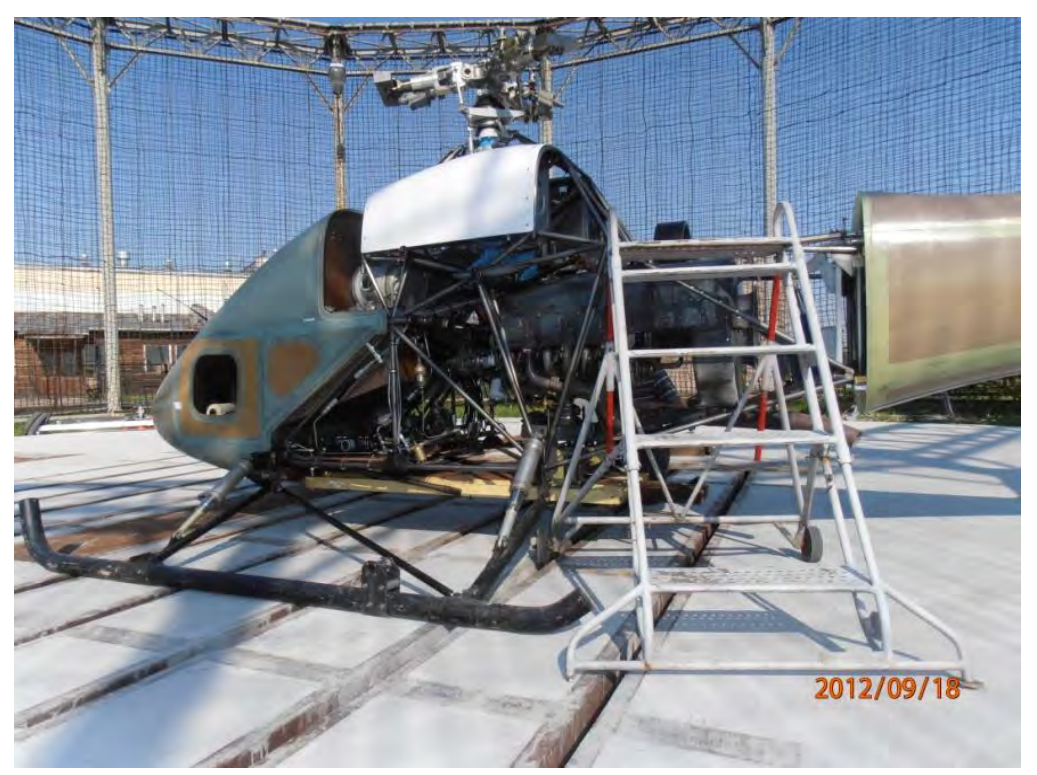

Rys. 1 Śmigłowiec ILX-27 na stanowisku prób naziemnych

\section{Obszar badawczy}

W przypadku projektów, w których poprawność funkcjonowania systemów sterowania i automatyki sterowania jest decydująca dla powodzenia i bezpieczeństwa realizacji lotów (a ma to miejsce w przypadku systemów bezzałogowych) wskazane jest, aby wszystkie elementy systemu sterowania (zarówno hardware jak i software) zabudowane zarówno w aparacie latającym jak i w stacji naziemnej, były przetestowane również w locie. Przed próbami w locie prototypowego śmigłowca prace te - ze względu na ograniczony czas projektu zrealizowane były tylko w części. Niektóre z elementów (autopilot, stacja naziemna, systemy transmisji danych) były wcześniej stosowane $\mathrm{w}$ innych opracowanych w ITWL bezzałogowych statkach powietrznych (rys.2). Niektóre jednak z podsystemów (AHRS, radiowysokościomierz) po integracji z systemem sterowania nie były testowanie $\mathrm{w}$ locie, podobnie zreszta jak algorytmy sterowania właściwe dla tego typu śmigłowców.

Wstępnie rozważane były następujące typy sterowania prototypem:

- bezprzewodowe zdalne sterowanie śmigłowcem przez operatora naziemnego bez żadnego wsparcia ze strony pokładowych systemów stabilizacji lub automatyzacji lotu. W uproszczeniu ujmując, w sposób zbliżony do sterowania zdalnie kierowanymi modelami latającymi, gdzie ruchy drążków sterowych manipulatora sterowania powodują odpowiednie ruchy tarczy 
sterującej, skoku śmigła ogonowego oraz wysterowania mocy zespołu napędowego;

- sterowanie zdalne ze wsparciem autostabilizatorem;

- sterowanie automatyczne, przez pokładowego autopilota $\mathrm{z}$ realizacja komend operatora ze stacji sterowania;

Zarówno drugi jak i trzeci wariant sterowania wymagaja pełnej wiedzy na temat aerodynamiki obiektu, tak aby współczynniki stabilizacji, czy też ogólnie ujmując prawa sterowania zawarte $\mathrm{w}$ algorytmach sterowania współdziałały $\mathrm{z}$ dynamiką śmigłowca. Weryfikację opisu śmigłowca (jego modelu matematycznego) można uzyskać np. przez badania w locie jego wersji załogowej, ale tego etapu w projekcie ILX-27 nie planowano.
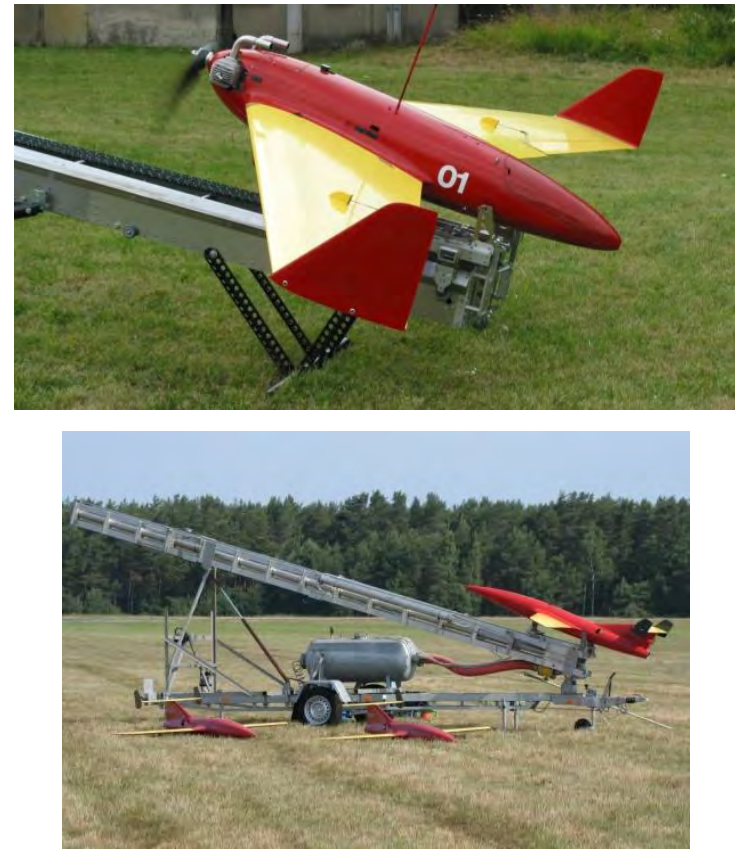

Rys. 2 Cel powietrzny systemu ZSMCP oraz odrzutowy cel powietrzny - ITWL

Decydując o wyborze systemu sterowania i kontroli śmigłowcem, za optymalny uznano system zdalnego sterowania przez naziemnego pilota-operatora $\mathrm{w}$ powiązaniu $\mathrm{z}$ telemetrycznym przekazem i prezentacją parametrów lotu w naziemnej stacji kontroli lotu.

Podejmując decyzje o systemie zdalnego sterowania wzięto pod uwage następujące aspekty konstrukcyjne śmigłowca oraz trudności oceny niebezpieczeństw wynikających $\mathrm{z}$ braku doświadczeń $\mathrm{W}$ przedstawionych zagadnieniach: 
- kompletny wirnik śmigłowca ILX-27 (tak jak i cały śmigłowiec) dotychczas nie latały, jedyne więc informacje na temat jego pracy w śmigłowcu, odpowiedzi na sterowanie i wartości sił obciążających siłowniki miały źródło obliczeniowe - nie było pewności, w jakim stopniu to prototypowe rozwiązanie obciąży człowieka $\mathrm{w}$ procesie sterowania (pilota w kabinie lub pilota - operatora zewnętrznego);

- głowica śmigłowca ILX-27 ma konstrukcję przegubową, charakterystyczną dla „klasycznych” śmigłowców. Problemem jest to, że modele zdalnie sterowane wyposażone są zwykle w mechaniczną lub elektroniczną stabilizację, same zaś wirniki główne latających modeli śmigłowców mają zdecydowanie charakter bardziej ,sztywny” niż głowice przegubowe, co $\mathrm{w}$ połączeniu $\mathrm{z}$ wysokimi obrotami skutkuje szybką reakcją, ale też dużym tłumieniem prędkości kątowych;

- zdalne sterowanie śmigłowców wymaga od operatora bardzo precyzyjnej widzialności śmigłowca, gdyż obserwacja kątów orientacji, prędkości kątowych i przesunięć jest praktycznie jedynym źródłem informacji o obiekcie dla koniecznych szybkich i odpowiednich korekt sterowania do utrzymania stabilnej pozycji lub stabilnego stanu lotu. Bardzo dobra widzialność (co oznacza jednak małą odległość między operatorem a śmigłowcem) kłóci się niestety z zasadami bezpieczeństwa;

- bardzo istotnym czynnikiem dla pewności zdalnego sterowania jest wartość opóźnienia pomiędzy stwierdzeniem konieczności korekty sterowania przez operatora a wykonaniem tej korekty. Na sumaryczne opóźnienie toru sterowania składa się wiele czynników. Istotnym było jednak, aby ocenić czy faktyczna wartość opóźnienia jest jeszcze akceptowalna dla konkretnego, sterowanego obiektu;

- przewidywano, że początkowe próby oderwania i zawisu wykonywane będą w bezpośredniej bliskości ziemi, co zwiększa bezpieczeństwo prób, ale niestety przekłada się na lot $\mathrm{z}$ wpływem ziemi, a więc w warunkach silnych zakłóceń opływu.

Na część tak zadanych pytań dały odpowiedź prace realizowane przez ITWL $\mathrm{w}$ ramach innego równolegle prowadzonego projektu. Opracowano w nim dwie bezzałogowe platformy pionowego startu i lądowania: dwuwirnikowy śmigłowiec w układzie podłużnym o udźwigu $25 \mathrm{~kg}$ oraz śmigłowiec w układzie klasycznym o masie startowej około $300 \mathrm{~kg}$ i udźwigu $50 \mathrm{~kg}$, stanowiący przebudowę śmigłowca jednomiejscowego na UAV (rys.3). Oba te prototypy podczas oblotu oraz $\mathrm{w}$ próbach $\mathrm{w}$ locie kontrolowane były systemem zdalnego sterowania ze wsparciem transmisją telemetryczną i prezentacją wyróżnionych parametrów na monitorach stacji naziemnej. Zwłaszcza doświadczenia z cięższym z obiektów okazały się cenne dla projektu ILX-27. Pomimo stosunkowo dużej masy - $300 \mathrm{~kg}$ opanowanie kontroli obiektu o zupełnie innych niż modele cechach dynamicznych (wirnik „huśtawkowy”) wymagało zaledwie kilku zawisów i lotów w różnych warunkach aerodynamicznych. 

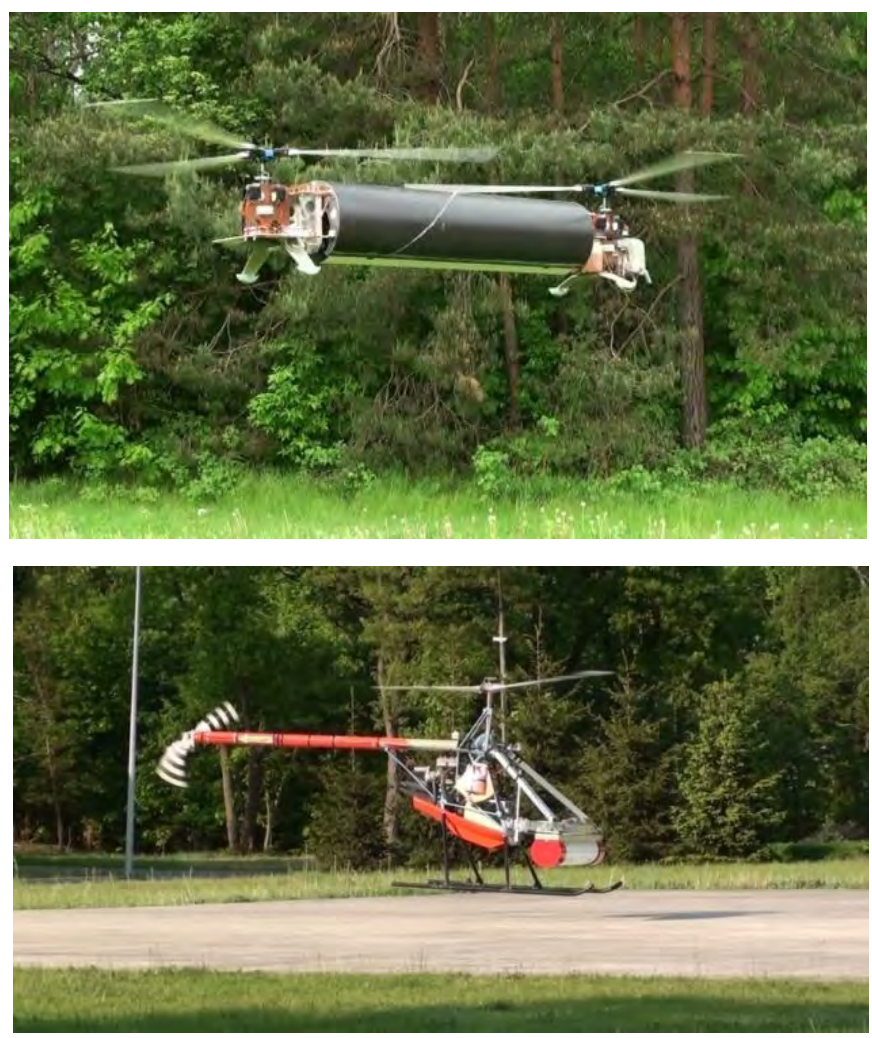

Rys. 3 Śmigłowiec w układzie podłużnym i śmigłowiec w układzie klasycznym podczas prób w locie

\section{Badania i próby w locie}

W czasie badań i prób w locie wykorzystywano wcześniej stosowaną w ITWL aparaturę zdalnego sterowania oraz naziemne stanowisko kontroli lotu (rys. 4)
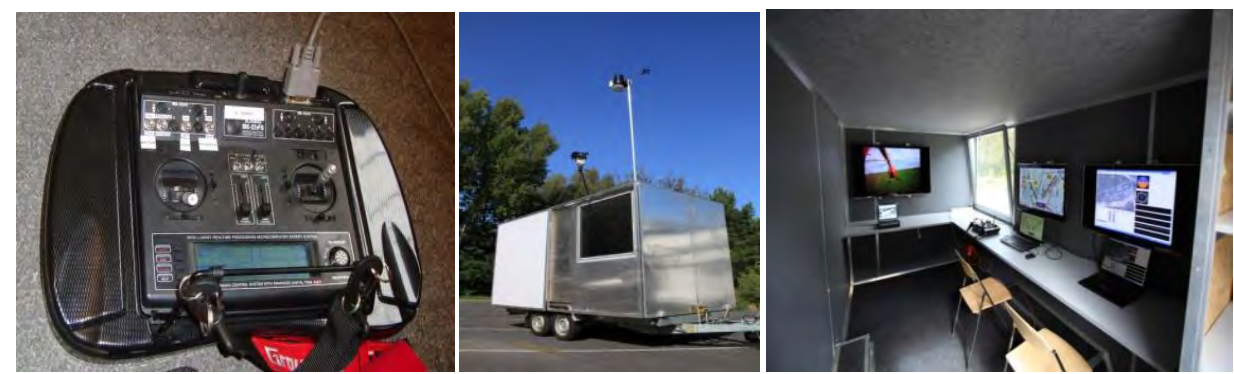

Rys.4 Wyglad zastosowanego manipulatora zdalnego sterowania oraz naziemna stacja kontroli lotu 
Flight tests of the unmanned helicopter ILX-27 - some selected issues Zagadnienia prób w locie bezzałogowego śmigłowca ILX-27

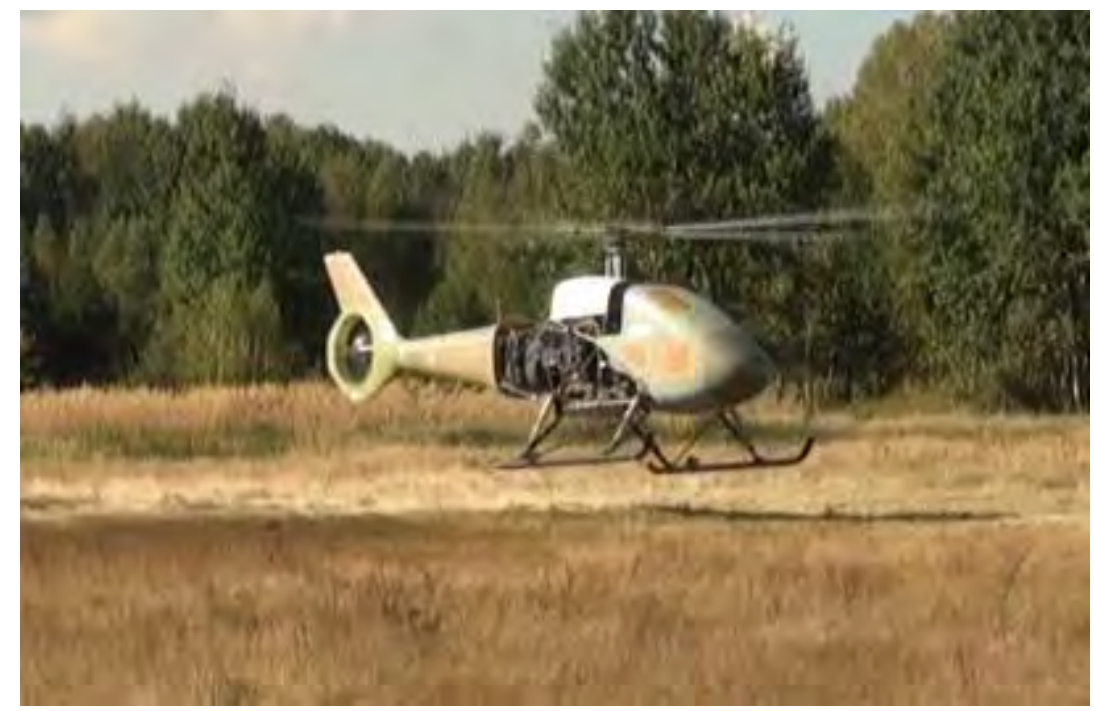

Rys. 5 Śmigłowiec ILX-27 w czasie zawisu

Celem oblotu i pierwszych prób było zebranie danych dotyczących:

- reakcji śmigłowca na sterowanie,

- określenie wysterowań trymowych dla ustalonych stanów lotu,

- dobór optymalnej czułości sterowania (elektronicznego przełożenia pomiędzy ruchami drążków manipulatora a ruchami tarczy sterującej).

Wyniki z oblotów pozwoliły na rozpoczęcie procesu identyfikacji dla weryfikacji modelu matematycznego $\mathrm{w}$ celu poprawienia obliczonych wstępnie współczynników stabilizacji i praw sterowania dla autopilota.

W celu określenia wysterowań niezbędnych dla utrzymania stabilnego zawisu (co w dużej mierze przekłada się na obciążenie pilota) wykonano wykresy położeń organów sterowania na tle pełnego $(100 \% \mathrm{w}$ każdą stronę) zakresu sterowania. Na rys. 6 przedstawiono wysterowanie w kanale odchylenia i skoku ogólnego oraz w kanale przechylenia i pochylenia (sterowanie tarczą sterująca), co odpowiada przypisaniu drążków manipulatora zdalnego starowania.

Analiza zapisów wysterowań $\mathrm{w}$ warunkach zawisu ustalonego pozwoliła również na określenie zapasów sterowania w poszczególnych kanałach (rys. 7). Można zauważyć, że dla utrzymania śmigłowca $\mathrm{w}$ zawisie wystarczą małe ruchy w poszczególnych kanałach sterujących. Dobrze widoczne mniejsze ruchy sterowania i łatwo czytelne położenia trymowe dla warunków ustalonego zawisu śmigłowca.

Patrząc na wykresy można również zauważyć bardzo mały zapas sterowania w kanale odchylenia (wysterowania skoku śmigła ogonowego). Wydaje się, że modernizacja tego zespołu będzie jedną z istotnych prac przygotowawczych przed kolejnymi lotami próbnymi. 


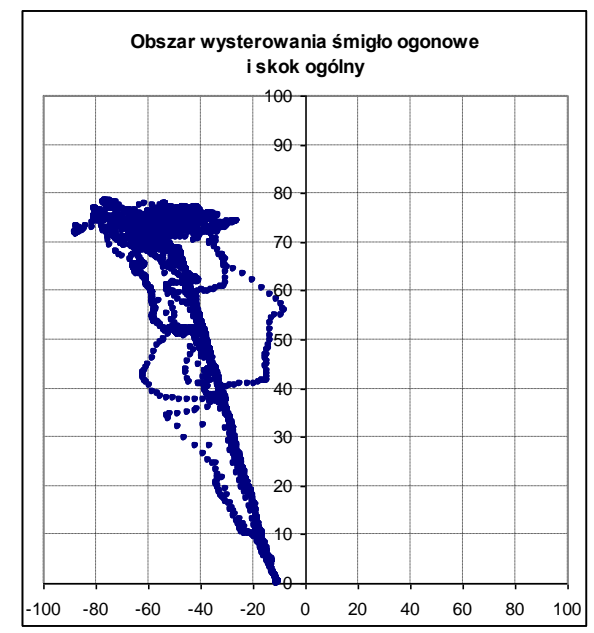

a)

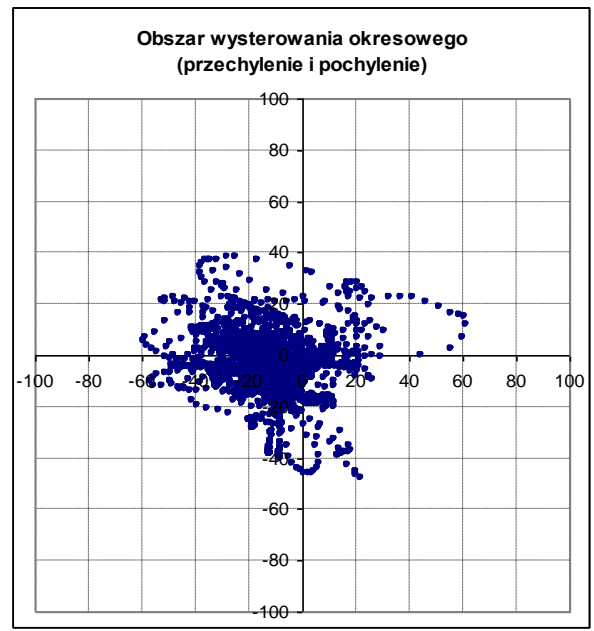

b)

Rys.6. Zapis wysterowania śmigłowca ILX-27 a) w kanale odchylenia $i$ skoku ogólnego oraz

b) w kanale przechylenia i pochylenia podczas pierwszych prób zawisu

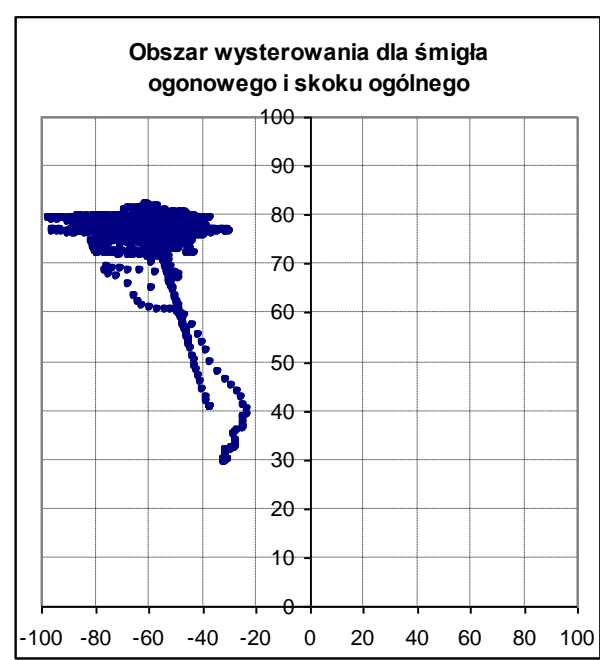

a)

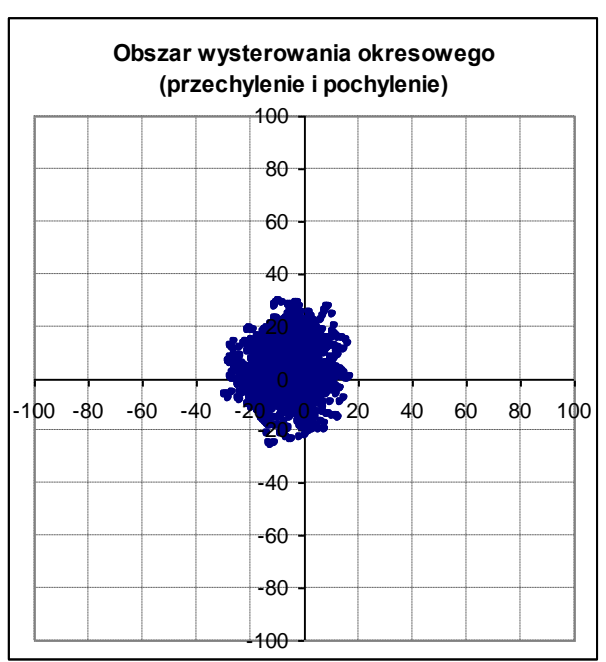

b)

Rys. 7 Zapis wysterowania śmigłowca ILX-27 podczas dalszych prób zawisu a) w kanale odchylenia i skoku ogólnego oraz b) w kanale przechylenia i pochylenia.

Rejestracja prędkości kątowych, przyspieszeń oraz kątów orientacji była realizowana z częstością $50 \mathrm{~Hz}$. Pozwoliło to, w powiązaniu z rejestracją ruchów sterowań na szybką (wręcz podczas sesji lotów) analizę odpowiedzi śmigłowca na sterowanie $\mathrm{w}$ wyróżnionych kanałach a również na kontrolę sprzężeń sterowań 
Flight tests of the unmanned helicopter ILX-27 - some selected issues Zagadnienia prób w locie bezzałogowego śmigłowca ILX-27

pomiędzy kanałami. Zastosowana uproszczona metoda analizy (konieczna z uwagi na deficyt czasu podczas badań) pozwoliła na oszacowanie poziomu sterowności w głównych kanałach sterowania. Skorygowano również wartości programowych czułości układu sterowania do maksymalnych poziomów bezwzględnych oraz dla poziomów akceptowalnych dla operatora-pilota. Na rys. 8-10 przedstawiono odpowiedzi śmigłowca na wymuszenia $\mathrm{w}$ kanałach przechylenia, pochylenia i odchylenia.

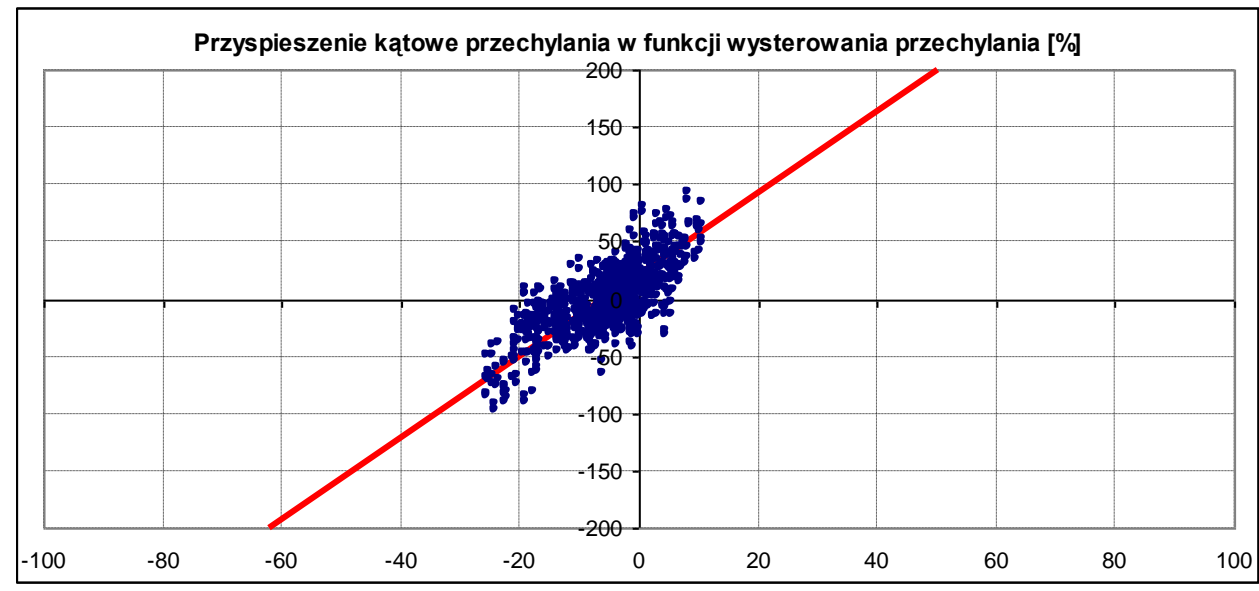

Rys.8 Graficzna prezentacja odpowiedzi śmigłowca ILX-27 na wymuszenie w kanale przechylenia o wartości $35^{\circ} / \mathrm{s}^{2}$ dla $10 \%$ wysterowania

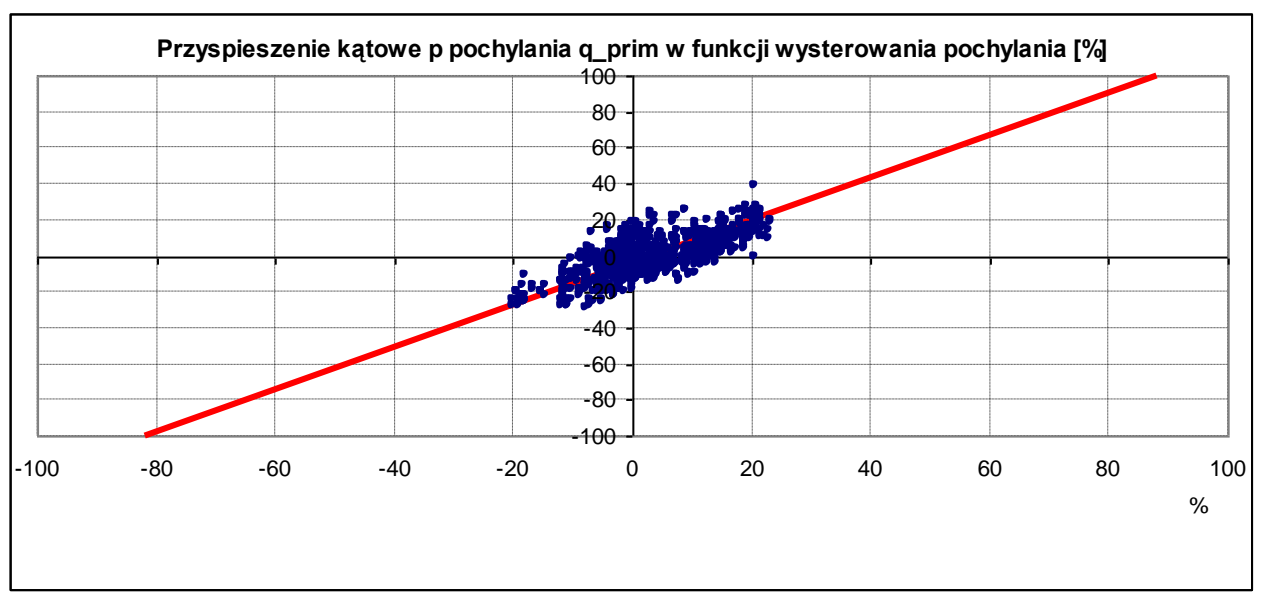

Rys.9 Graficzna prezentacja odpowiedzi śmigłowca ILX-27 na wymuszenie $w$ kanale pochylenia o wartości $12^{\circ} / \mathrm{s}^{2}$ dla $10 \%$ wysterowania 


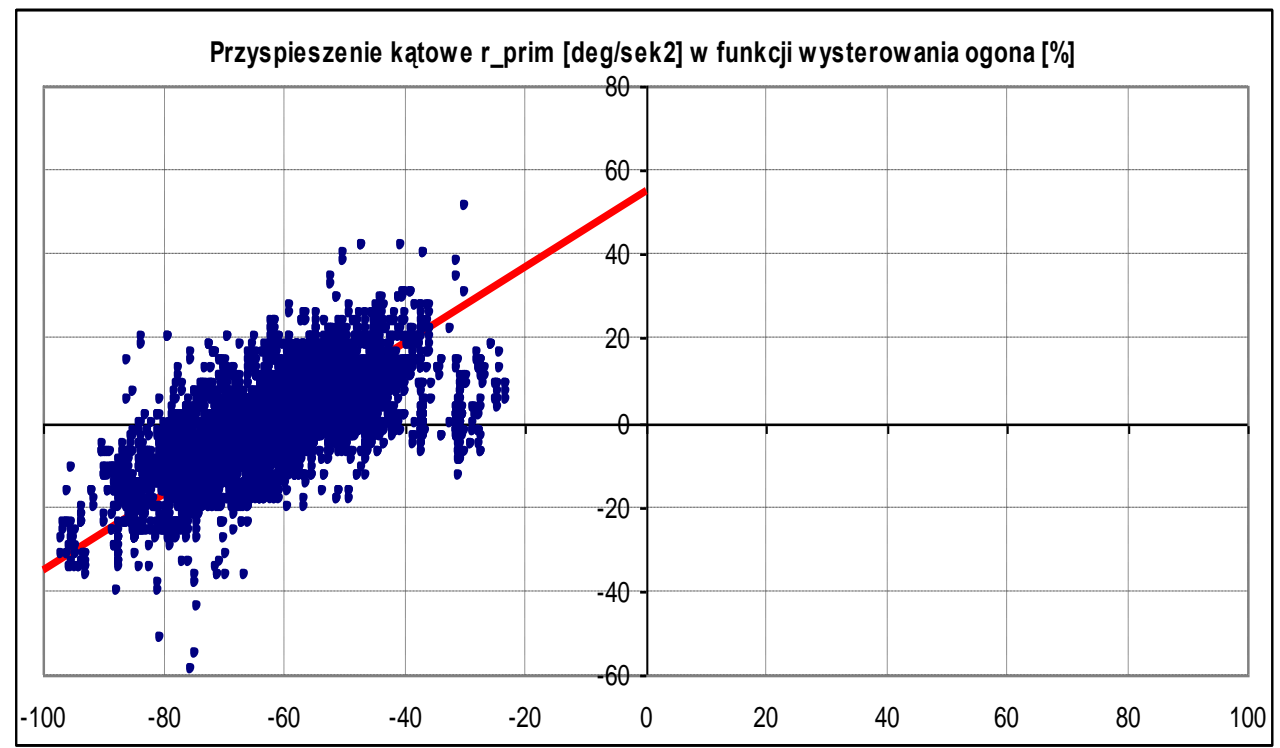

Rys.10 Graficzna prezentacja odpowiedzi śmigłowca ILX-27 na wymuszenie w kanale odchylenia o wartości $9^{0} / s^{2}$ dla $10 \%$ wysterowania

Wykonywane próby w locie śmigłowca ILX-27 wskazały z jednej strony na trafność większości zaproponowanych rozwiązań, z drugiej zaś ujawniły większe niż spodziewane obciążenie operatora-pilota podczas sterowania. Dodatkowo odbywało się to bez zauważalnego postępu w „opanowywaniu” śmigłowca, mierzonego jako wzrost precyzji zachowania zadanych parametrów lotu $\mathrm{w}$ kolejnych próbach. Jako jedną $\mathrm{z}$ potencjalnych przyczyn tego stanu podejrzewano opóźnienie w torze sterowania.

Na sumaryczne opóźnienie składają się:

- opóźnienie manipulatora,

- opóźnienie komputera dopasowującego sygnał,

- opóźnienie toru radiomodemowego transmisji bezprzewodowej,

- opóźnienie modułu odbioru, opóźnienie komputera pokładowego,

- opóźnienie modułu sterownika serwomechanizmów,

- opóźnienie wynikające z ograniczonej prędkości serwomechanizmów hydraulicznych.

Dla oceny wpływu opóźnienia w torze sterowania śmigłowcem wykonano kolejne próby wykorzystując specjalnie zaprojektowany i wykonany układ opóźniający dla symulatora PC (rys. 11). 
Flight tests of the unmanned helicopter ILX-27 - some selected issues Zagadnienia prób w locie bezzałogowego śmigłowca ILX-27
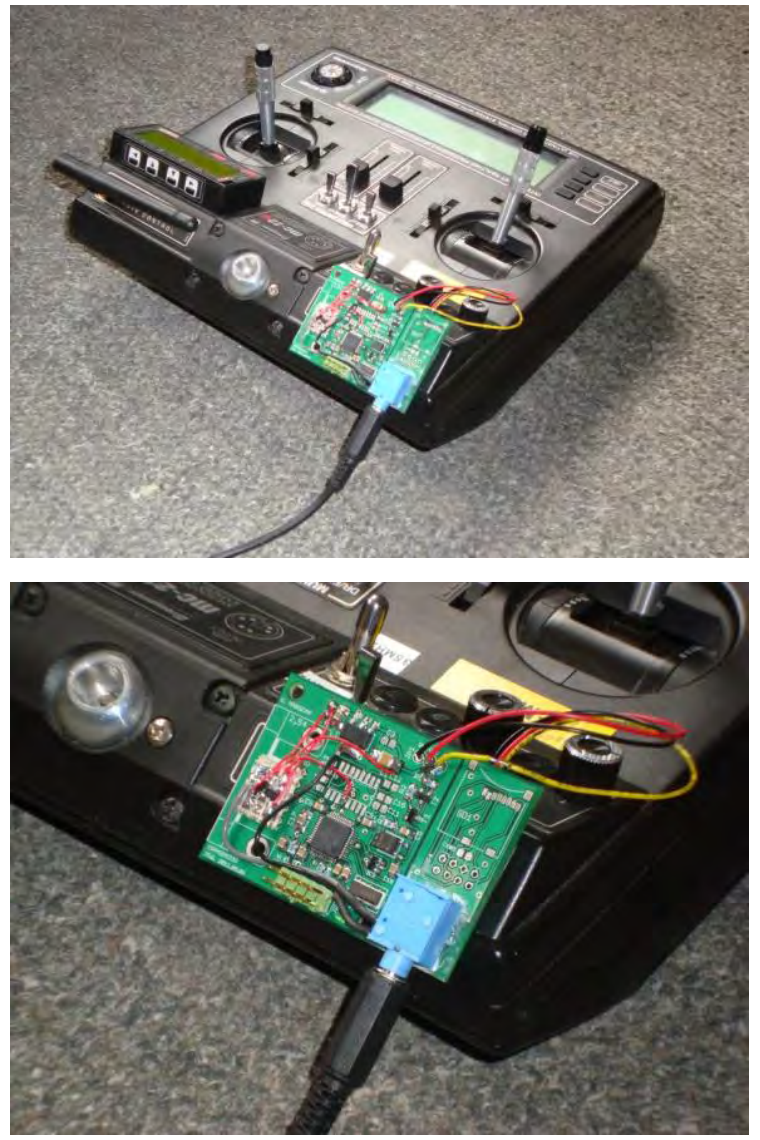

Rys. 11 Manipulator zdalnego sterowania wraz z układem opóźniajacym wykorzystanym do eksperymentu symulacyjnego opóźnienia

Specjalnie zaprojektowany układ opóźniający umożliwiał symulację opóźnienia sumarycznego toru sterowania w zakresie wartości od 20 do $600 \mathrm{~ms}$. Wykonane próby pozwoliły sformułować poniższe wnioski:

- opóźnienie w torze sterowania ma istotny wpływ na łatwość i pewność sterowania śmigłowcem w trybie bez stabilizacji, przy czym czynnik opóźnienia jest tym bardziej znaczący im mniej stateczny jest śmigłowiec (czyli im szybszych reakcji wymaga od operatora do zachowania parametrów równowagi)

- dla modelu symulacyjnego śmigłowca o charakterystyce odpowiedzi na sterowanie zbliżonej do śmigłowca ILX-27 stwierdzono, że sumaryczne opóźnienie w torze sterowania o wartości większej niż $300 \mathrm{~ms}$ jest już krytycznie duże (praktycznie uniemożliwia utrzymanie zadanych parametrów lotu), zaś opóźnienie o wartości poniżej 100 ms jest mało istotne 
i jest stosunkowo łatwe do korekty przez wprawnego i doświadczonego operatora.

- w wyniku porównania reakcji śmigłowca ILX-27 podczas prób w locie z eksperymentem symulacyjnym z wykorzystaniem układu opóźniającego oceniono sumaryczne opóźnienie toru sterowania na 220 do $240 \mathrm{~ms}$.

Z uwagi na wartość sumarycznego opóźnienia bliską szacowanej wartości krytycznej zmodyfikowano tor sterowania poprzez eliminację komputera dopasowującego sygnał dla radiomodemu i rekonfigurację łącza radiomodemowego co pozwoliło na redukcję opóźnienia toru sterowania do szacowanej wartości poniżej $160 \mathrm{~ms}$.

\section{Wnioski}

W czasie badań i prób w locie stwierdzono:

- Poprawne reakcje sterowania - analiza zapisów rejestracyjnych wskazuje na poprawną i wystarczającą sterowność śmigłowca w analizowanych kanałach sterowania.

- Duża różnica w czułości sterowania - wyznaczone sterowności (a więc czułości sterowania) w poszczególnych kanałach znacząco się różnią co stanowi utrudnienie dla operatora, ale jest łatwe i szybkie do skorygowania programowego.

- Mały zapas skoku ogólnego - loty próbne realizowane w zawisie na wysokości oddziaływania wpływu ziemi wymagały wysterowania skoku ogólnego w zakresie 75 do $80 \%$.

- Mały zapas sterowania śmigłem ogonowym - podczas lotów próbnych zarejestrowano wysterowanie skoku śmigła ogonowego w warunkach równowagi $\mathrm{W}$ zawisie bliskie lewym ogranicznikom wysterowania. Dla bezpiecznej kontynuacji badań w locie celowe jest zwiększenie ciagu maksymalnego śmigła ogonowego, co przesunie trymowe wysterowanie bliżej centrum obszaru sterowania kątem odchylenia.

- Opóźnienia w torze sterowania - reakcje śmigłowca ILX-27 na sterowanie $\mathrm{w}$ trybie sterowania manualnego $\mathrm{z}$ wykorzystaniem bezprzewodowego toru transmisji sygnałów sterowania wskazują na znaczące opóźnienie sumaryczne. Zarejestrowano i zanalizowano źródła opóźnień w układzie sterowania. Oceniono że sumaryczne opóźnienie wynosi szacunkowo 220 do $240 \mathrm{~ms}$ (w zestawieniu z wartością krytyczną wynoszącą około $300 \mathrm{~ms}$ dla tego typu obiektu).

Prototyp wydaje się dobrą platformą badawczą i w miarę prób i naturalnych modyfikacji rokuje jako przyszłościowy bezzałogowy system zadaniowy 
Flight tests of the unmanned helicopter ILX-27 - some selected issues Zagadnienia prób w locie bezzałogowego śmigłowca ILX-27

\section{Bibliografia}

[1] Hajuk J., Popowski s., Szumański K.: Badanie granic manewrowości śmigłowca na modelu latającym, Prace Instytutu Lotnictwa, 2004.

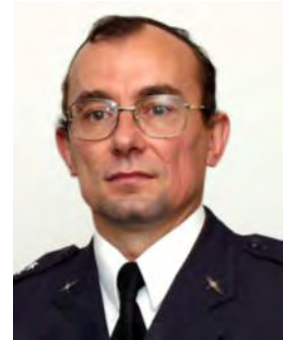

Dr inz. Ryszard Sabak - ukończyt studia w roku 1984 na Wydziale Mechanicznym Wojskowej Akademii Technicznej. Stopień doktora nauk technicznych, specjalność diagnostyka techniczna uzyskat w 2002r. Pracuje na stanowisku adiunkta w Instytucie Technicznym Wojsk Lotniczych. Specjalizuje się $w$ konstrukcji oraz badaniach bezzatogowych statków powietrznych.

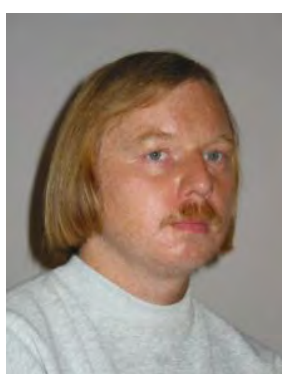

mgr inz. Jarosław Hajduk - absolwent Wydziału Mechaniki Energetyki i Lotnictwa Politechniki Warszawskiej. Pracuje na stanowisku Starszego Specjalisty w Instytucie Technicznym Wojsk Lotniczych. Zajmuje sie badaniami, konstrukcja oraz metodami wykorzystania bezzałogowych statków powietrznych. 


\title{
MANAGING DO-178 COMPLIANCE WITH IBM RATIONAL PLATFORM
}

Leverage state-of-the-art best practices to develop avionics software

\section{ZARZĄDZANIE ZGODNOŚCIĄ Z DO-178 PRZY UŻYCIU PLATFORMY IBM RATIONAL}

Wykorzystanie najlepszych praktyk do tworzenia oprogramowania dla awioniki

\author{
Mehmet Kerim Çakmak \\ Technical Sales, CEE Region
}

\begin{abstract}
DO178 is a standard for avionic software for the aerospace industry which can be used as a guidance to determine if the software product will perform reliability in airborne environment. The standard has 5 different certification levels each of which has a certain set of objectives. The certification levels are determined depending on how critical the system or subsystem is. To address DO178 objectives, companies need a defined systems and software engineering process that can delineate workflows, inputs, outputs, roles and responsibilities. The major objectives outlined in the DO-178 standard include;

- Requirements engineering

- Design and development.

- Validation and verification

- Engineering tasks, such as configuration and change management

In this presentation, we will try to explain the main principles of the DO178 standard very briefly and try to give an insight about how the objectives of this standard can be satisfied.
\end{abstract}

Keywords - Safety, DO-178, requirements engineering, systems engineering, aerospace Streszczenie: DO-178 jest norma dla oprogramowania awionicznego dla przemystu lotniczego, która może być stosowana w charakterze wytycznych $w$ celu ustalenia, czy oprogramowanie będzie wykazywać niezawodność w środowisku lotniczym. Norma ma pięć różnych poziomów certyfikacji, z których każdy ma określony zestaw celów. Poziomy certyfikacji sa ustalone w zależności od tego, na ile krytyczny jest system lub podsystem. $W$ celu spetnienia celów DO-178 przedsiębiorstwa potrzebuja zdefiniowanych systemów $i$ procesu tworzenia oprogramowania, które moga prezentować przebiegi procesów, wartości wejściowe, wyjściowe, role i zakresy odpowiedzialności. Główne cele nakreślone w normie DO-178 obejmują:

- ustalenie wymagań

- projektowanie i rozwój

- walidacje $i$ weryfikacje

- zadania inżynierskie, takie jak konfiguracja i zarzadzanie zmianami.

W niniejszej prezentacji spróbujemy wyjaśnić w skrócie główne zasady normy DO-178 oraz sposób, w jaki cele tej normy moga zostać spetnione, a odpowiednie poziomy certyfikacji osiagnięte dla tworzonego systemu lub podsystemu. and the relevant certification level can be achieved for a system or subsystem under development.

Stowa kluczowe - Bezpieczeństwo, DO-178, ustalenie wymagań, projektowanie systemów, lotnictwo i kosmonautyka. 
Managing DO-178 compliance with IBM rational platform

Zarzadzanie zgodnościa z DO-178 przy użyciu platformy IBM rational

\section{IBM Rational DO-178B overviev}

The DO-178B standard identified considerations for the development of avionics software, including the demonstration of adherence of up to 66 objectives. Despite the term, this standard is a set of de facto require- ments for the certification of airborne software. The standard classifies the safety level of airborne software into five classes, shown in Table 1.

To meet these objectives, the standard identifies five key plans and a set of work products that must be produced to demonstrate compliance. The plans are typically, but not necessarily, written as textual documents and can generally be reused from project to project with little change once they have been created. The other documents, however, are used as specific guidance or project evidence and are very labor-intensive to create by hand. Effective use of tooling can facilitate the development and manage- ment of these work products. Table 2 lists the primary DO-178B lifecycle data and the tooling used to create and manage in the IBM ${ }^{\circledR}$ Rational ${ }^{\circledR}$ DO-178B solution.

The DO-178B standard is concerned with the safety of software delivered within avionics systems to be certified. Its primary goal is to help enable the consistency of the development of deterministically safety software. Since this is an unachievable goal, the standard instead focuses on process assurance rather than system assurance. This is done through a combination of detailed traceability among related work products, reviews, audits, independence of verification, path testing, and where appropriate, the use of tested, qualified tools. The basic perspective of the standard is that a development organization is guilty of failing to meet the standard unless clear evidence can be provided otherwise. It is the additional level of rigor-and the production and maintenance of this evidence - that gener- ates most of the incremental cost of adopting the standard.

DO-178B is not prescriptive in terms of process or tooling and is not at all concerned with business objectives such as profitability, productivity and efficiency. As the developers of these systems, we, however, must concern ourselves with them, or we run the risk of going out of business.

Your first DO-178B project will likely add between a 25 percent and 40 percent increase in cost over a non-certified project, but the industry average is 75 percent to a whopping 150 percent. This high cost has a number of root cases, but chief among them are a lack of understanding of the overall process, lack of early involvement of the Federal Aviation Administration (FAA) - or its representative, a Designated Engineering Representative(DER) - and low productivity because of ineffective tooling and inefficient processes. 
Mehmet Kerim Çakmak

Table 1: DO-178B safety levels

\begin{tabular}{|c|l|c|c|c|}
\hline $\begin{array}{c}\text { Safety } \\
\text { Level }\end{array}$ & \multicolumn{1}{|c|}{ Description } & $\begin{array}{c}\text { Probability } \\
\text { of failure }\end{array}$ & Objectives & $\begin{array}{c}\text { Objectives } \\
\text { with } \\
\text { independence }\end{array}$ \\
\hline A \\
Catastrophic & $\begin{array}{l}\text { Failure condition results in a } \\
\text { catastrophic condition for the } \\
\text { aircraft; major fatalities, including } \\
\text { crew }\end{array}$ & $\leq \mathbf{1 0 - 9}$ & $\mathbf{6 6}$ & $\mathbf{2 5}$ \\
\hline $\begin{array}{c}\text { B } \\
\text { Hazardous }\end{array}$ & $\begin{array}{l}\text { Failure condition results in a } \\
\text { major failure condition for the } \\
\text { aircraft, reducing the capability of } \\
\text { the crew to cope; potential fatal } \\
\text { injuries but not to flight crew }\end{array}$ & $\leq \mathbf{1 0 - 7}$ & $\mathbf{6 5}$ & $\mathbf{1 4}$ \\
\hline $\begin{array}{c}\text { C } \\
\text { Major }\end{array}$ & $\begin{array}{l}\text { Failure condition results in a } \\
\text { minor failure condition for the } \\
\text { aircraft, resulting in a reduction of } \\
\text { safety margins; possibly including } \\
\text { injuries }\end{array}$ & $\mathbf{3 1 0 - 5}$ & $\mathbf{5 7}$ & $\begin{array}{c}\text { independent } \\
\text { reviews }\end{array}$ \\
\hline $\begin{array}{c}\text { D } \\
\text { Minor }\end{array}$ & $\begin{array}{l}\text { Failure conditions have no impact } \\
\text { on aircraft operational capability } \\
\text { and would involve crew actions } \\
\text { within their capabilities; possible } \\
\text { discomfort to passengers or crew }\end{array}$ & $\mathbf{1 0 - 5}$ & $\mathbf{2 8}$ & $\mathbf{0}$ \\
\hline E & $\begin{array}{l}\text { No safety impact, no affect on } \\
\text { operational capability of the } \\
\text { aircraft or increase in crew } \\
\text { workload }\end{array}$ & & $\mathbf{0}$ & $\mathbf{0}$ \\
No Effect & & & & \\
\hline
\end{tabular}

Certain activities stand out in terms of the cost and effort required to provide adequate evidence of compliance. The first of these is traceability, which relates specific data in different activities to ensure that they are consistent. The DO-178B standard requires, for example, that all software requirements are met by the code, and that all code is at hand to meet the software requirements. This means the system has no require- ments not met, nor dead code, nor code for which there are no requirements. Traceability also can allow for change impact analysis and helps us reason about the cost and impact of requirements, software and platform changes.

Another activity that can be extraordinarily expensive is cover- age testing. DO-178B requires structural code coverage (SC) testing of each line of code visited during verification testing for level $\mathrm{C}$ software, decision coverage (DC) testing of each branch that is tested for level B, and Modified Condition Decision Coverage (MCDC) testing of each condition in a branch independently for level A. 
Managing DO-178 compliance with IBM rational platform

Zarzadzanie zgodnościa z DO-178 przy użyciu platformy IBM rational

The difference can be seen when looking at a basic coding example:

If $(\mathrm{a}|| \mathrm{b} \& \& \mathrm{c})$

$\mathrm{x}++$;

SC testing requires a single test that executes the TRUE case, for example, $\mathrm{a}=\mathrm{b}=\mathrm{c}=1$. DC testing requires two test cases, one TRUE and one FALSE, for example, $\mathrm{a}=\mathrm{b}=\mathrm{c}=1$ and

$\mathrm{a}=\mathrm{b}=\mathrm{c}=0$. MCDC testing requires, in general, $\mathrm{N}+1$ test cases, where $\mathrm{N}$ is the number of conditions in the logic. In

this case four tests are required not the eight possible variants, as is believed by some, as shown in the truth table below ${ }^{1}$ :

The goal of the Rational DO-178B solution is to help provide evidence of the consistent development of safe software in a cost-effective, efficient and productive manner. This goal is achieved through a combination of process guidance, with project management and governance tooling integrated with engineering tools.

\section{Rational DO-178B solution}

The Rational DO-178B solution is designed to address the concerns of systems and software development in the aerospace industry through a combination of best practices, customizable process solutions, tools, tool integrations and services.

\section{Best practices and methods}

The Harmony process is a software development process composed from a set of best practices. For avionics applications, we have taken a subset of the practices, mapped them, in detail, to the DO-178B standard, and called the delivery process the Integrated Software Development Process for DO-178B (ISDP-178). The process content is created and managed with the Rational Method Composer (RMC). The content can be published in many different formats, the most common as an HTML website as shown in Figure 1.

Table 2: Truth table

\begin{tabular}{llll}
\hline A & B & C & OUTCOME \\
\hline 0 & 0 & 0 & FALSE \\
\hline 1 & 0 & 0 & TRUE \\
\hline 0 & 1 & 0 & FALSE \\
\hline 0 & 1 & 1 & TRUE \\
\hline
\end{tabular}

Identifying, codifying and executing the MCDC test cases for a complex piece of software is clearly an extremely expensive undertaking if done manually.

DO-178A required DC testing of the executable object code for level A, but DO-178B can allow MCDC at the source code level as long as it is combined 
with a source-to-binary comparison for all relevant code.

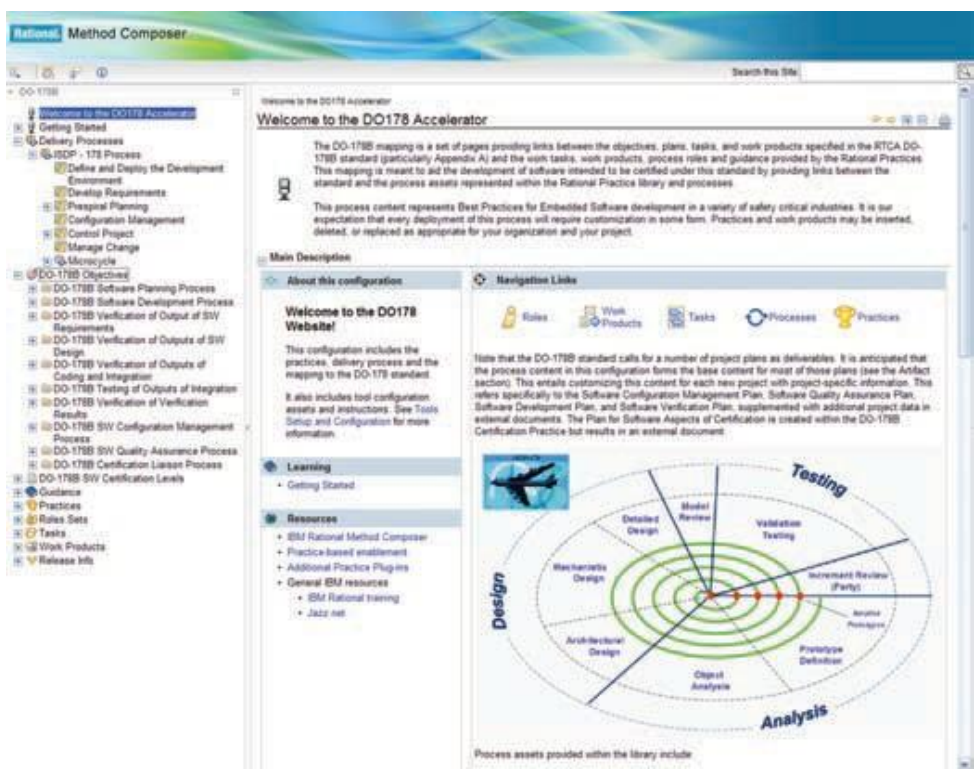

Fig.1 ISDP-178

Figure 2 shows the high level overview of work activities for an avionics project. Pre-spiral planning creates schedules and various plans, including the five key plans required for DO-178B compliance:

- Plan for software aspects of certification

- Software development plan

- Software configuration management plan

- Software quality assurance plan

- Software verification plan

The Configuration Management work activity details how updates to the work product baselines are managed and audited. The Define and Deploy the Development Environment specifies how tools and processes are installed, configured and managed. The Control Project activity manages and governs the project and helps update risk management plan, safety and reliability analyses, tools and processes. The Manage Change activity defines the workf low for managing changes to baselined work products.

Most of the developer's work happens within the microcycle activity. This activity is iterated with a four- to six-week cycle time.

The key best practices included within the ISDP-178 process consist of detailed process descriptions and various forms of guidance, including checklists, templates, definitions, tool mentors and examples. 


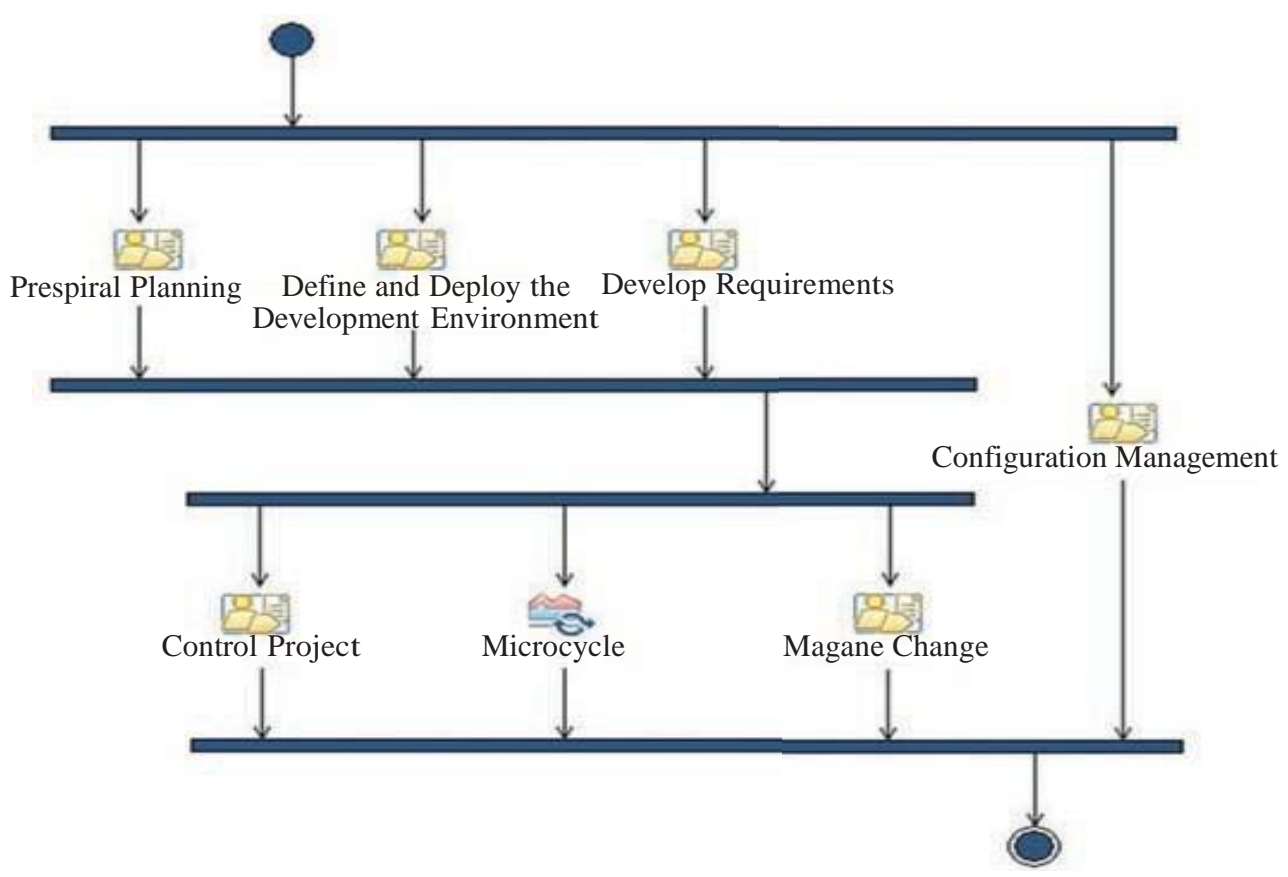

Fig. 2 ISDP process overview

The most important best practices within the ISDP-178 process include:

- Incremental development

- Continuous integration

- Executable requirements modeling

- Continuous execution

- High-fidelity design modeling

- Five views of architecture

- Test-driven development

- Risk management

- Dynamic planning

- Outcome-based metrics for project governance

While detailed description of these practices is beyond the scope of this paper ${ }^{2}$, we will brief ly discuss how this process realizes the incremental development process, how require- ments are managed and how high-fidelity modeling integrates with other best practices.

The incremental workf low that is known as the microcycle in the ISDP-178 process is shown in Figure 3. The time frame for this iteration is generally four to six weeks long. The primary output of the microcycle is a verified and validated version of the avionics software. However, in addition to the tested code baseline, 
evidentiary work products are also produced, including requirements and design, traceability matrix, configuration data, quality assurance reports and audits, review results and so on, as outlined in Table 2.

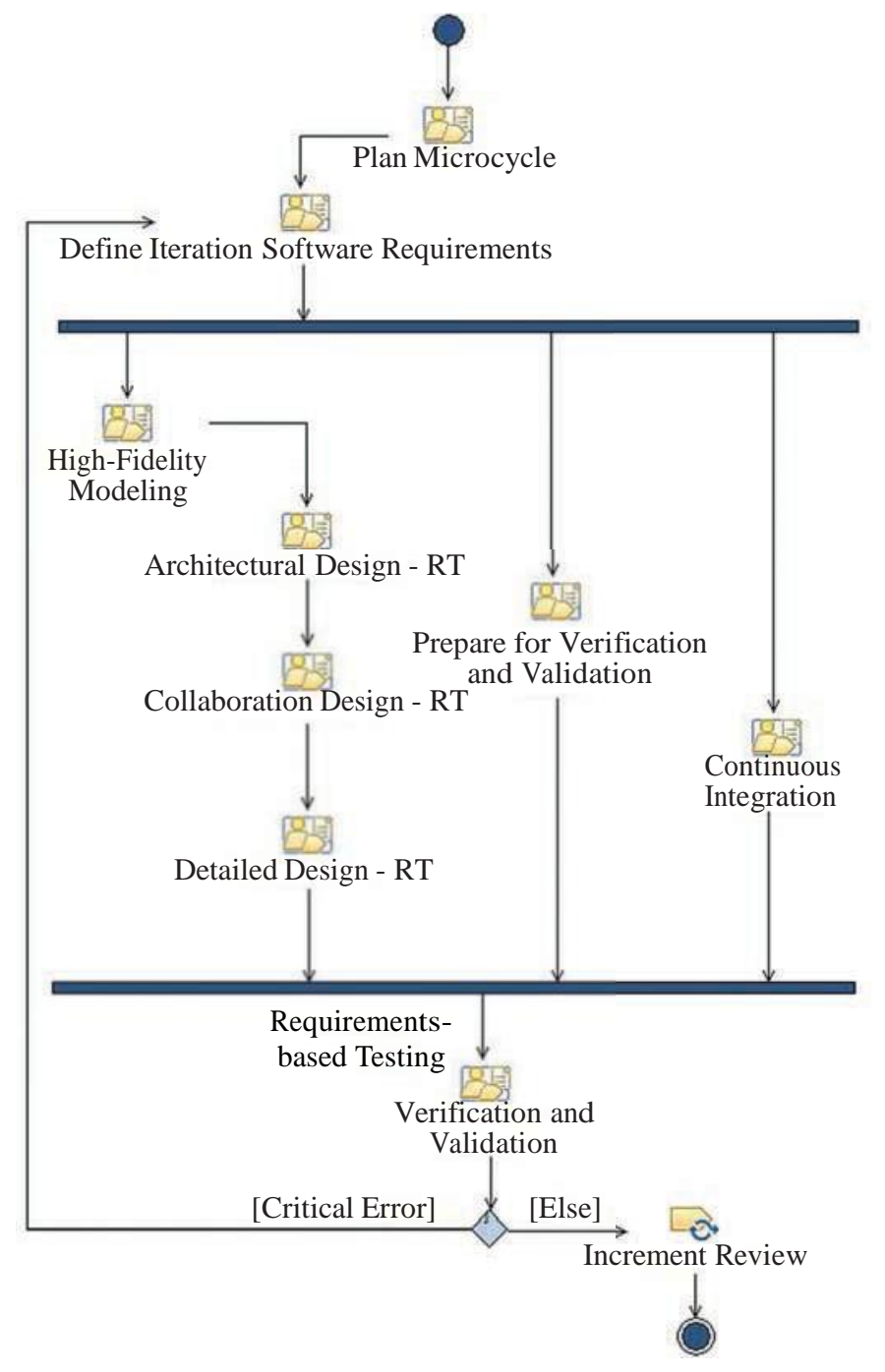

Fig. 3 Microcycle workflow

A difference between a traditional waterfall lifecycle and the ISDP-178 is the incremental nature of requirements development. The software requirements to be realized and validated within a microcycle are fully elaborated only within that microcycle. This is done in the "Define Iteration Software Requirements" activity of Figure 3. This workf low is elaborated in Figure 4. 


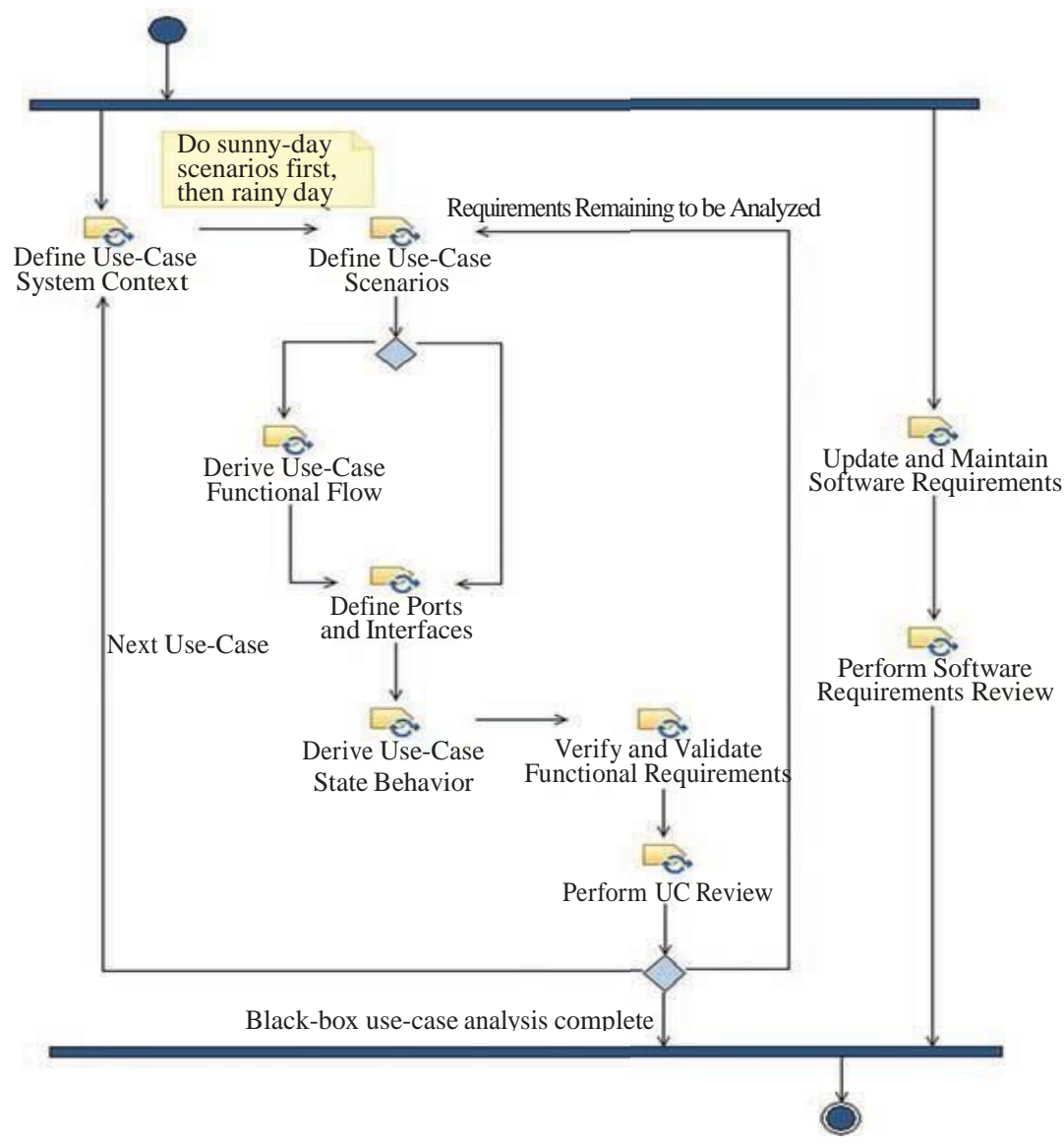

Fig. 4 Define iteration software requirements

Most of the tasks shown in Figure 4 deal with the mechanics of analyzing the requirements for completeness, consistency, accuracy and correctness through use-case analysis. This work results in new or updated requirements in the software requirements specification in the tasks shown along the right side of the figure.

Figure 5 shows the workf low for the High-Fidelity Modeling activity in Figure 3. In this activity, the functionally correct soft- ware baseline is created and unit tested through the application of Test-Driven Development. The inner loop of Figure 5, known as the nanocycle, is applied at a high frequency, typically

20 - 30 minutes. In this loop, a small increment is made in the developer's software design - in the Identify Classes and Objects and Refine Collaboration tasks - and code is generated in the Translate task. Consequently, unit tests are 
developed and applied to the evolving software in the Develop Unit Test Plan and Validate Collaboration tasks. Thus, small increments are made in the functionality of the software, and the software is then incrementally unit tested to avoid defects. The design tasks-Architectural Design, Collaboration Design and Detailed Design - optimize this functionally correct software baseline at different levels of abstraction. The continuous integration of the software takes place in parallel with this, as shown in the Configuration Management activity

in Figure 2. This means that the evolving baselines from differ- ent developers are regularly integrated and tested together.

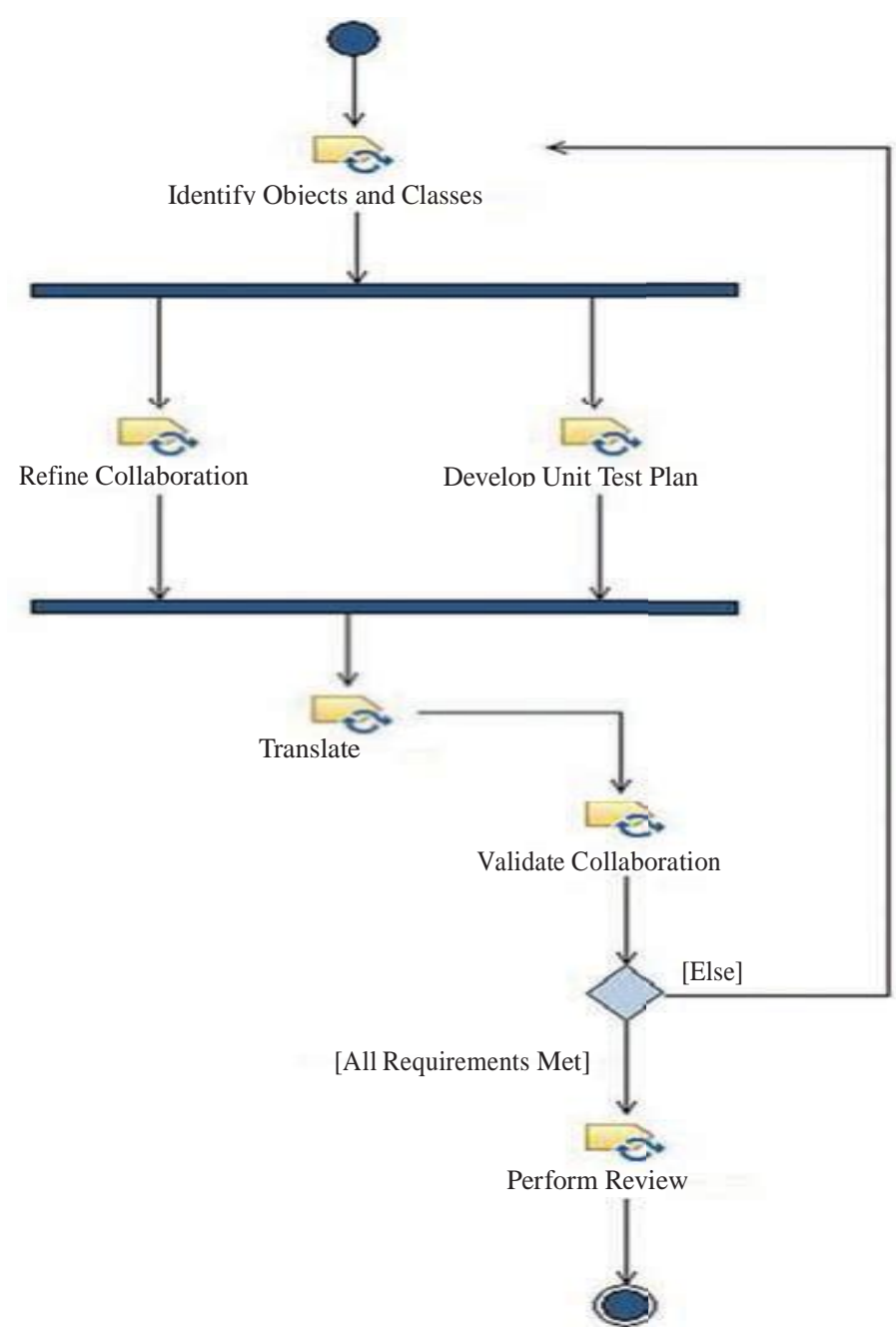

Fig.5 High fidelity modeling 
Managing DO-178 compliance with IBM rational platform

Zarzadzanie zgodnościa z DO-178 przy użyciu platformy IBM rational

\section{DO-178B mapping}

Best practices guide developers and other engineering staff as they develop the various work products needed for a certifiable software product. This guidance includes work product tem- plates, checklists, and other kinds of guidelines. In addition, the process has a detailed mapping of the 66 objectives of the DO-178B standard to the process content. This helps facilitate the creation of the plans to meet the standard, as well as reviews and audits of the process to support certification needs. Figure 6 shows one of the pages of links. Each objective of the standard has its own page, with links to relevant work task, work products, checklists and other forms of guidance.

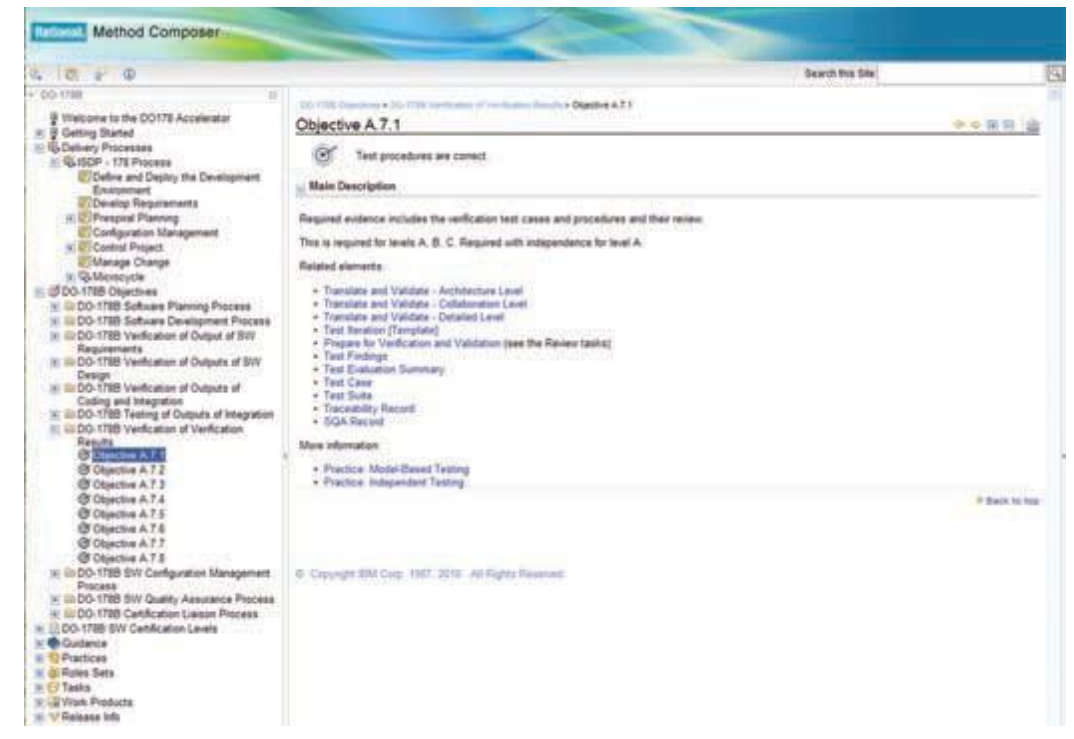

Fig. 6 Mapping of DO-178B and ISDP-178 process

\section{Process planning}

The definition of the process - deciding what you need to do, and in what order while consuming and producing which work products-is only part of the management problem. Filling out the planning side of the equation and details of the application of the process results in a project plan. This can be represented in many ways, such as a work item list, a PERT chart or a detailed Gantt chart. This plan assigns dates, efforts and resources so that a project can be estimated and managed.

Tasks defined in the best practice workf lows are specified in the Rational Method Composer tool. This allows for both process definition and customization and for automation in planning and enactment. The work tasks defined in RMC result in task templates in the planning tools of the IBM Rational Team Concert ${ }^{\mathrm{TM}}$ (RTC) 
software that are the building blocks of the project plan. These task templates, initiated for particular work efforts, assigned to resources, and given cost estimates, form the backbone of a project plan.

\section{Project enactment}

As a project is run, the plan is realized through a process called project enactment: the controlled execution of the project plan. This is often a weak area for many organizations, but it is crucial for success. Project enactment is enabled within the Rational Aerospace solution though a combination of monitor- ing task outcomes, visualizing progress, risks and obstacles, and when appropriate, updating the plan to ref lect reality.

The first of these aspects is monitoring, which comes into the picture in the form of Key Performance Indices (KPIs) that measure progress. Common metrics include requirements complete, requirements volatility, project velocity and defect density. These metrics usually can be gathered transparently, without distracting the engineers from their work, through the automation of information gathering and fusion of that information. That is, the engineers needn't stop and fill out reports since the information is gathered naturally as work items are completed and testing is executed.

This leads to the second aspect: visualization of project data. It is important to realize that not all stakeholders can equally obtain all project information. Project managers, customers, team leads, discipline leads, engineers, quality assurance and testing engineers have different responsibilities and are concerned about different information. In RTC, stakeholder- specific dashboards can be created to visualize different aspects of the project data to show only relevant information to each project stakeholder. These dashboards can be updated automat- ically and dynamically as a project moves forward, requiring no additional effort other than their original definition.

The last aspect of project enactment is updating the plans. A key problem in the management of the creation of avionics software is that plans are made with incomplete information, as with all software projects, and are therefore wrong in at least some aspects. If your plan is to ref lect "truth on the ground" of your project, you must update it to ref lect actual effort expended, dates of task completion and defect data. Because the RTC tool is designed to integrate the work environment with near-real-time project data and the project plan, it is simpler to update the plan with that project data, improving the accuracy of the project plan as the project progresses.

\section{Process customization}

Of course, all companies developing avionics software don't do so in a cultural or process vacuum. This means that the process must be tailored to fit into the overarching process and business culture of your company. Since the process assets are held in the Rational Method Composer software, it is simpler to modify the process content and align it with your company's processes and required work products and goals. 
Managing DO-178 compliance with IBM rational platform

Zarzadzanie zgodnościa z DO-178 przy użyciu platformy IBM rational

\section{IBM Jazz platform tooling}

Process is a crucial piece of the puzzle since it defines what needs to be done, who does it and when it must be done. Once the process is defined, tooling can automate the creation and manipulation of work products. Good tool integration allows for data exchange without information loss. Figure 7 shows the primary tools of the Rational Aerospace solution.

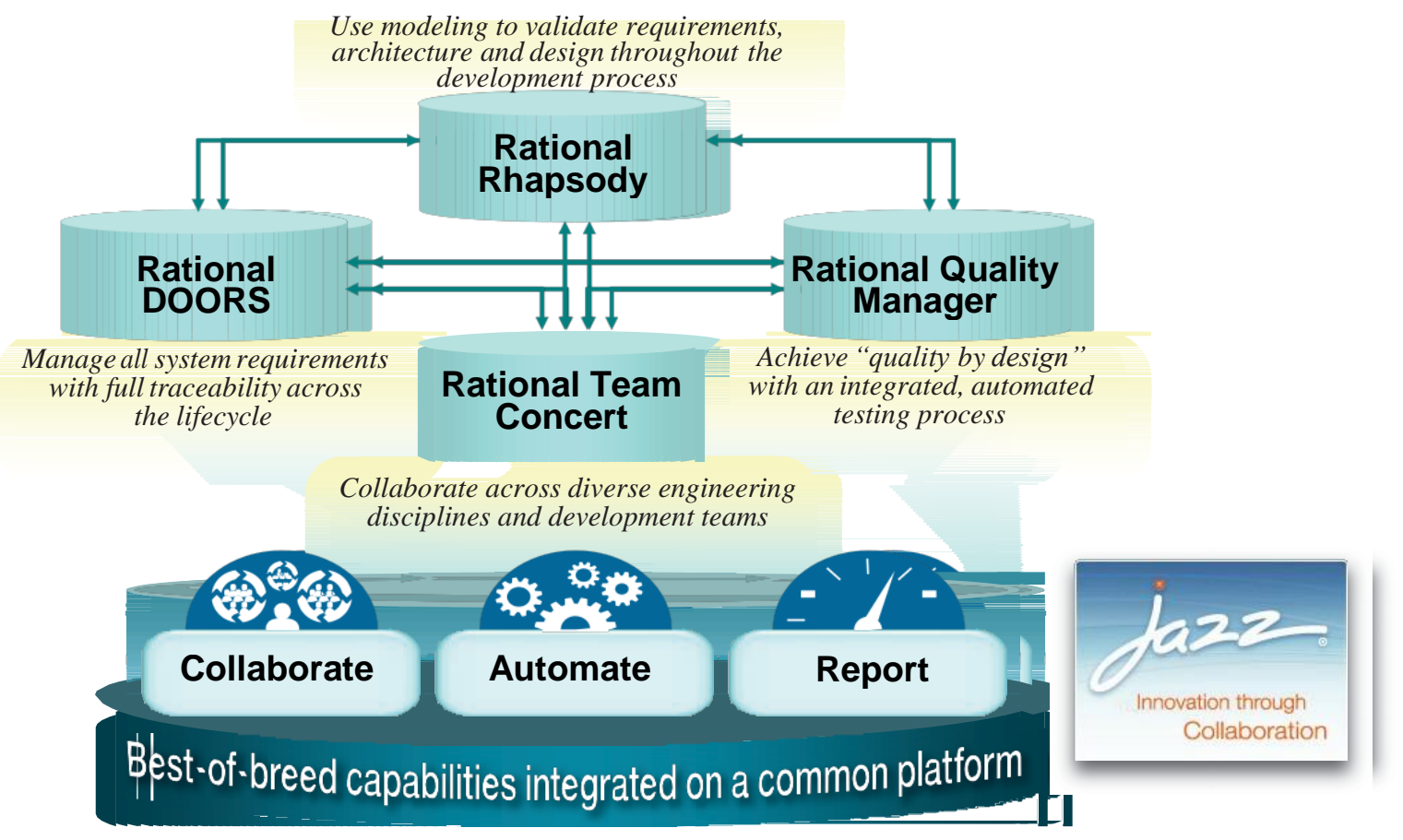

Fig.7 Rational Aerospace solution tooling

The IBM DOORS ${ }^{\circledR}$ tool is a functionality-rich requirements management tool in the industry. In the Rational Aerospace solution, DOORS is responsible for requirements management and the maintenance of traceability.

The IBM Rhapsody ${ }^{\circledR}$ tool provides state-of-the-art modeling capabilities for UML and SysML, systems engineering and software development. These capabilities include model-based debugging and testing facilities, safety and reliability analysis, integration with other modeling tools such as MATLAB Simulink, and production-quality code generation.

The Rational Quality Manager (RQM) tool provides test management, including test authoring, optimization, scheduling and execution. RQM supports collaboration with metrics tracking and quality dashboards. 
The Rational Test Real Time (RTRT) tool executes system and software tests, including the laborious structure, decision and modified condition decision coverage (MC/DC) testing. It is fully qualified as a DO-178B verification tool.

Rational Method Composer (RMC) software supports authoring, management and publishing process assets. The ISDP-178 process content is available in RMC format and can be used to define the processes and to generate process templates to be used for project planning and governance in Rational Team Concert.

The Rational Team Concert tool runs atop the Jazz ${ }^{\mathrm{TM}}$ open framework and provides project planning and governance solutions. With built-in configuration and change management facilities, it supports project planning through the addition of tasks based on task templates imported from your RMC-compliant process definition. Project governance is supported with highly customizable dashboards to monitor project progress metrics.

\section{Lifecycle data}

Tooling exists to automate tasks and help with the creation and management of important work products. The DO-178B process defines a number of different and important work products in projects. Some of the key work products, referred to as lifecycle data, are shown in Table 3, along with the Rational tooling and practices that address them.

Table 3. DO-178B lifecycle data

\begin{tabular}{|l|l|l|l|c|}
\hline Abbreviation & Document title & Rational solution tool(s) & $\begin{array}{l}\text { Rational solution practice } \\
\text { or task }\end{array}$ & $\begin{array}{c}\text { Delivered } \\
\text { to FAA? }\end{array}$ \\
\hline PSAC & $\begin{array}{l}\text { Plan for software } \\
\text { aspects of } \\
\text { certification }\end{array}$ & $\begin{array}{l}\text { Microsoft Word Template, } \\
\text { Rational Method Composer, } \\
\text { Rational Team Concert }\end{array}$ & $\begin{array}{l}\text { Pre-spiral planning, create } \\
\text { certification plan, review } \\
\text { certification plan }\end{array}$ & Yes \\
\hline SDP & $\begin{array}{l}\text { Software } \\
\text { development plan }\end{array}$ & $\begin{array}{l}\text { Microsoft Word Template, } \\
\text { Rational Method Composer, } \\
\text { Rational Team Concert }\end{array}$ & $\begin{array}{l}\text { Pre-spiral planning, create } \\
\text { SW development plan, } \\
\text { review SW development } \\
\text { plan }\end{array}$ & No \\
\hline SVP & $\begin{array}{l}\text { Software } \\
\text { verification plan }\end{array}$ & $\begin{array}{l}\text { Microsoft Word Template, } \\
\text { Rational Method Composer, } \\
\text { Rational Team Concert }\end{array}$ & $\begin{array}{l}\text { Pre-spiral planning, create } \\
\text { SW verification plan, } \\
\text { review SW verification } \\
\text { plan }\end{array}$ & No \\
\hline SCMP & $\begin{array}{l}\text { Software } \\
\text { configuration } \\
\text { management plan }\end{array}$ & $\begin{array}{l}\text { Microsoft Word Template, } \\
\text { Rational Method Composer, } \\
\text { Rational Team Concert }\end{array}$ & $\begin{array}{l}\text { Pre-spiral planning, create } \\
\text { configuration manage- } \\
\text { ment plan, create change } \\
\text { management plan, review } \\
\text { configuration management } \\
\text { plan, review change } \\
\text { management plan }\end{array}$ & No \\
\hline SQAP & $\begin{array}{l}\text { Software quality } \\
\text { assurance plan }\end{array}$ & $\begin{array}{l}\text { Microsoft Word Template, } \\
\text { Rational Method Composer, } \\
\text { Rational Team Concert }\end{array}$ & $\begin{array}{l}\text { Pre-spiral planning, create } \\
\text { QA plan, review QA plan }\end{array}$ & No \\
\hline SRS & $\begin{array}{l}\text { Software } \\
\text { requirements } \\
\text { standard }\end{array}$ & $\begin{array}{l}\text { IBM Rational DOORS, } \\
\text { Rational Method Composer, } \\
\text { Rational Team Concert }\end{array}$ & $\begin{array}{l}\text { Update and maintain SW } \\
\text { requirements, perform SW } \\
\text { requirements review }\end{array}$ & No \\
\hline
\end{tabular}


Managing DO-178 compliance with IBM rational platform

Zarzadzanie zgodnościa z DO-178 przy użyciu platformy IBM rational

\begin{tabular}{|c|c|c|c|c|}
\hline Abbreviation & Document title & Rational solution tool(s) & $\begin{array}{l}\text { Rational solution practice } \\
\text { or task }\end{array}$ & $\begin{array}{l}\text { Delivered } \\
\text { to FAA? }\end{array}$ \\
\hline SDS & $\begin{array}{l}\text { Software design } \\
\text { standard }\end{array}$ & $\begin{array}{l}\text { IBM Rational DOORS, IBM } \\
\text { Rational Rhapsody, Rational } \\
\text { Method Composer, Rational } \\
\text { Team Concert }\end{array}$ & \begin{tabular}{lll} 
High-ficelity & \multicolumn{2}{c}{ modeling } \\
architectural design & $\mathrm{RT}$, \\
collaboration design & $\mathrm{RT}_{\text {, }}$ \\
detailed design & $\mathrm{RT}$ \\
identify classes & and \\
objects & &
\end{tabular} & No \\
\hline SCS & $\begin{array}{l}\text { Software coding } \\
\text { standard }\end{array}$ & $\begin{array}{lcr}\text { Rational DOORS, } & \text { Rational } \\
\text { Rhapsody, Rational } & \text { Method } \\
\text { Composer, } & \text { Rational } & \text { Team } \\
\text { Concert } & & \\
\end{array}$ & $\begin{array}{l}\text { High-fidelity modeling, } \\
\text { Harchitectural design RT, } \\
\text { collaboration design RT, } \\
\text { detailed design RT, translate }\end{array}$ & No \\
\hline SRD & $\begin{array}{l}\text { Software } \\
\text { requirements }\end{array}$ & Rational DOORS & $\begin{array}{l}\text { Update and maintain SW } \\
\text { requirements, perform SW } \\
\text { requirements review }\end{array}$ & No \\
\hline SDD & $\begin{array}{l}\text { Software design } \\
\text { description }\end{array}$ & Rational Rhapsody & $\begin{array}{l}\text { High-fridelity modeling, } \\
\text { architectural design RT, } \\
\text { collaboration design RT, } \\
\text { detailed design RT, identify } \\
\text { classes and objects }\end{array}$ & No \\
\hline $\mathrm{SC}$ & Source code & $\begin{array}{l}\text { Rational Rhapsody, Rational } \\
\text { Method Composer }\end{array}$ & $\begin{array}{lcc}\text { High-tidelity } & \text { modeling, } \\
\text { architectural design } & \mathrm{RT}, \\
\text { collaboration design } & \mathrm{RT}^{2}, \\
\text { detailed design } & \mathrm{RT} \text {, } \\
\text { translate } & & \end{array}$ & No \\
\hline EOC & $\begin{array}{l}\text { Executable } \\
\text { object code }\end{array}$ & Project compiler $^{3}$ & $\begin{array}{l}\text { High-fidelity modeling, } \\
\text { translate, continuous } \\
\text { integration, integrate and } \\
\text { build }\end{array}$ & No \\
\hline SVCP & $\begin{array}{l}\text { Software verifi- } \\
\text { cation cases and } \\
\text { procedures }\end{array}$ & $\begin{array}{l}\text { IBM Rational Quality } \\
\text { Manager, IBM Rational Test } \\
\text { RealTime }\end{array}$ & $\begin{array}{l}\text { High-fidelity modeling, } \\
\text { prepare for verification } \\
\text { and validation }\end{array}$ & No \\
\hline SVR & $\begin{array}{l}\text { Software verifi- } \\
\text { cation results }\end{array}$ & $\begin{array}{l}\text { Rational Quality Manager, } \\
\text { Rational Test RealTime }\end{array}$ & $\begin{array}{l}\text { Veritication and validation, } \\
\text { run tests, analyze test failure }\end{array}$ & No \\
\hline SECI & $\begin{array}{l}\text { Software } \\
\text { lifecycle } \\
\text { environment } \\
\text { configuration } \\
\text { index }\end{array}$ & $\begin{array}{l}\text { Rational Team Concert or } \\
\text { IBM Rational ClearCase } \AA \\
\text { or IBM Rational Synergy }\end{array}$ & $\begin{array}{l}\text { Define and deploy the } \\
\text { development environment } \\
\text { set up tools, verify tool } \\
\text { configuration and installa- } \\
\text { tion, set up configuration } \\
\text { management environment, } \\
\text { refine and deploy the } \\
\text { development environment, } \\
\text { change and deliver } \\
\text { configuration items }\end{array}$ & No \\
\hline SCI & $\begin{array}{l}\text { Software } \\
\text { configuration } \\
\text { index }\end{array}$ & $\begin{array}{l}\text { RationalTeam Concert or } \\
\text { IBM Rational ClearQuest or } \\
\text { Rational Synergy }\end{array}$ & $\begin{array}{l}\text { Configuration manage-ment, } \\
\text { change and deliver } \\
\text { configuration items, perform } \\
\text { configuration audit }\end{array}$ & Yes \\
\hline STM & $\begin{array}{l}\text { Software trace } \\
\text { matrix }\end{array}$ & $\begin{array}{l}\text { Rational DOORS, Rational } \\
\text { Rhapsody, Rational Quality } \\
\text { Manager }\end{array}$ & $\begin{array}{l}\text { Develop requirements, link } \\
\text { stakeholder require-ments to } \\
\text { system require-ments, trace } \\
\text { use cases to system require- } \\
\text { ments, define iteration SW } \\
\text { requirements, update and } \\
\text { maintain SW require-ments, } \\
\text { identify objects and classes, } \\
\text { translate, develop tests }\end{array}$ & No \\
\hline$\overline{\mathrm{PR}}$ & Problem reports & $\begin{array}{l}\text { Rational Team Concert or } \\
\text { Rational ClearQuest or IBM } \\
\text { Rational Change }\end{array}$ & $\begin{array}{lrr}\text { Manage } & \text { change, } & \text { submit } \\
\text { change request, } & \text { review } \\
\text { change request, assign change } & \text { change } \\
\text { request, resolve } & \text { change } \\
\text { request, verify change } & \text { cequest, close change request }\end{array}$ & No \\
\hline
\end{tabular}




\begin{tabular}{|l|l|l|l|c|}
\hline Abbreviation & Document title & Rational solution tool(s) & $\begin{array}{c}\text { Rational solution practice } \\
\text { or task }\end{array}$ & $\begin{array}{l}\text { Delivered } \\
\text { to FAA? }\end{array}$ \\
\hline SCMR & $\begin{array}{l}\text { Software } \\
\text { configuration } \\
\text { management } \\
\text { records }\end{array}$ & $\begin{array}{l}\text { Rational Team Concert or } \\
\text { Rational ClearCase or } \\
\text { Rational Synergy }\end{array}$ & $\begin{array}{l}\text { Configuration management, } \\
\text { change and deliver configura- } \\
\text { tion tems,perform configura- } \\
\text { tion audit }\end{array}$ & No \\
\hline SQAR & $\begin{array}{l}\text { Software quality } \\
\text { assurance } \\
\text { records }\end{array}$ & $\begin{array}{l}\text { Rational Team Concert or } \\
\text { Rational ClearCase or } \\
\text { Rational Synergy }\end{array}$ & $\begin{array}{l}\text { Review stakeholder require- } \\
\text { ments, review system require- } \\
\text { ments, perform UC review, } \\
\text { perform SW requirements } \\
\text { review, perform review, } \\
\text { perform test review }\end{array}$ & No \\
\hline SAS & $\begin{array}{l}\text { Software } \\
\text { accomplishment } \\
\text { summary }\end{array}$ & $\begin{array}{l}\text { Word Template, Rational } \\
\text { Method Composer, Rational } \\
\text { Team Concert }\end{array}$ & Perform increment review & Yes \\
\hline
\end{tabular}

\section{What about tool qualification?}

A common question regarding tooling for avionics projects has to do with tool qualification. Tool qualification is required when a tool removes manual steps without subsequent verification of the output. The DO-178B standard identifies two tool catego- ries of interest. The first, development tools, refers to tools that could introduce defects into the products. Such tools perform development activities; for example, include requirement man- agement, modeling, editing, compilation and linking. To be qualified, a development tool must have a known and correct output for all possible inputs. Because this is, at the very least, extremely expensive, almost no one uses qualified tools for development. For example, there are no qualified compilers in the market because of the difficulty in such a high degree of quality assurance. As a result, development tools are used, but the output of the tool must be verified. Ultimately, this is done during software verification to ensure that the baselined code has the right behavior.

The other kind of potentially qualified tools are verification tools. These are tools used for testing. It is very common to use qualified verification tools such as Rational Test Real Time to automate the testing process.

\section{Summary}

The Rational aerospace solution is an integration of best practices, tooling and tool integrations to help facilitate the development of certifiable avionics software. The practices are captured in the ISDP-178 delivery process and are modified using the Rational Method Composer to align them with different business environments and cultures. ISDP-178 uses the state-of-the-art best practices for embedded software devel- opment, including incremental development, continuous inte- gration, test-driven development and high-fidelity modeling, to capture the development work products in a rigorous and efficient way. These practices result in task templates that can be used in Rational Team Concert for both project planning and governance. The practices map to the DO-178B standard to support the creation of plans for certifiable software. 
Managing DO-178 compliance with IBM rational platform

Zarzadzanie zgodnościa z DO-178 przy użyciu platformy IBM rational

Various practices are supported with integrated automation by a set of tools for requirements, design, coding and testing. These tools help facilitate industry standard OLSC interfaces running on top of the Jazz platform and provide information exchange among tools and stakeholders.

In short, the Rational aerospace solution provides a suitable environment for the development of certified avionics software.

\section{References}

[1] Software Considerations in Airborne Systems and Equipment Certification, RTCA/DO-178B, RTCA, Inc., 1992

[2] Second Annual Report for Clarification of DO-178B, "Software Considerations in Airborne Systems and Equipment Certification", RTCA/DO248A, RTCA, Inc., 2000; "Design Assurance Guidance for Airborne Electronic Hardware," RTCA/ DO-254, RTCA. Inc., 1992

[3] Guidelines and Methods for Conducting the Safety Assessment Process on Civil Airborne Systems and Equipment, SAE/ARP4761, Society of Automotive Engineers, 1996

[4] Certification Considerations for Highly-Integrated or Complex Aircraft Systems, SAE/ARP4754A Society of Automotive Engineers, 2010

[5] Boehm, Barry A Spiral Model of Software Development and Enhancement ACM SIGSOFT Software Engineering Notes, August 1986

[6] Douglass, Bruce Powel Real-Time Agility, Addison-Wesley, 2009

[7] Douglass, Bruce Powel Real-Time UML 3rd Edition: Advances in the UML for Real-Time Systems, Addison-Wesley, 2004

[8] Ericson, Clifton Hazard Analysis Techniques for System Safety, WileyInterscience, 2005

[9] Royce, Winston Managing the Development of Large Software Systems, Proceedings of IEEE WESCON, August 1970

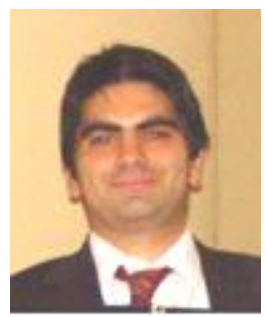

Mehmet Kerim Çakmak, PhD. Born in 1973. Completed his formal education in 2004 with PhD degree in High Energy and Particle Physics from the Middle East Technical University in Ankara. He's got many and various certificates in Information Technologies (IT). Recently employed at the IBM, Ankara, as the Client Technical Professional - CEE Region. Earlier experience gained at the Ayrotek Ltd., and Bildem Ltd., Ankara, as the IT consultant. 


\title{
SAFETY OF MACHINERY - DETERMINATION OF PERFORMANCE LEVEL
}

\section{BEZPIECZEŃSTWO MASZYN - WYZNACZANIE POZIOMU ZAPEWNIENIA BEZPIECZEŃSTWA}

\section{Leszek Kasprzyczak}

\author{
Instytut Technik Innowacyjnych EMAG
}

\begin{abstract}
The article presents a method for determining the performance level (PL) on the basis of the PN-EN ISO 13849-1 standard, which is harmonized with the machinery directive 2006/42/EC. The risk assessment and risk reduction criteria, according to PN-EN ISO 12100, were briefly characterized. The focus was put on determining the required performance level PLr on the basis of a risk graph. The method was presented how to use a safety function composed of input-, logicaland execution subsystems. It was demonstrated how to determine the achieved PL for a safety function composed of hardware elements on the basis of a safety category, mean time to dangerous failures (MTTFd), diagnostic coverage (DC), and immunity to common cause failures $(C C F)$.
\end{abstract}

Keywords: machinery directive 2006/42/EC, performance level PL, safety category, mean time to dangerous failures MTTFd, diagnostic coverage DC, common cause failures CCF.

Streszczenie: $W$ artykule omówiono metodę wyznaczania Poziomu Zapewnienia Bezpieczeństwa PL na podstawie normy PN-EN ISO 13849-1, która jest zharmonizowana $z$ dyrektywa maszynowa 2006/42/WE. Krótko scharakteryzowano zasady oceny i zmniejszenia ryzyka wg normy PN-EN ISO 12100. Skoncentrowano się na określeniu wymaganego poziomu PLr na podstawie grafu ryzyka. Przedstawiono praktyczna realizację funkcji bezpieczeństwa złożonej $z$ podsystemów wejściowych, logicznych $i$ wykonawczych. Pokazano sposób wyznaczania osiagniętego PL dla funkcji bezpieczeństwa złożonej z elementów sprzętowych na podstawie struktury układu (kategorii), wartości średniego czasu pomiędzy niebezpiecznymi uszkodzeniami (MTTFd), pokrycia diagnostycznego (DC) i odporności na uszkodzenia spowodowane wspólna przyczyna (CCF).

Stowa kluczowe: dyrektywa maszynowa 2006/42/WE, poziom zapewnienia bezpieczeństwa PL, kategorie bezpieczeństwa, średni czas pomiędzy niebezpiecznymi uszkodzeniami MTTFd, pokrycie diagnostyczne DC, uszkodzenia spowodowane wspólna przyczyna CCF. 
Safety of machinery - determination of performance ...

Bezpieczeństwo maszyn - wyznaczanie poziomu ...

\section{Wstęp}

Poziom Zapewnienia Bezpieczeństwa PL (ang. Performance Level) jest bardzo istotnym parametrem określającym stopień odporności na defekty danej funkcji bezpieczeństwa w układzie sterowania maszyny. Sposoby wyznaczania PL opisane są W angielskojęzycznej normie PN-EN ISO 13849-1 [1]. Norma ta jest zharmonizowana z dyrektywą maszynową (MD) 2006/42/WE, która wprowadzona została w Polsce rozporządzeniem Ministra Gospodarki. Do interpretacji przepisów dyrektywy opracowany został przewodnik Komisji Europejskiej. Celem wprowadzenia dyrektywy maszynowej było ułatwienie swobodnego przepływu towarów i zlikwidowanie technicznych przeszkód w handlu wewnątrz krajów Europejskiego Obszaru Gospodarczego.

$\mathrm{Z}$ dyrektywą MD zharmonizowana jest również angielskojęzyczna norma PN-EN ISO 12100 [2], w której zawarto dwa kluczowe aspekty dotyczące zasad oceny ryzyka i zmniejszania ryzyka. Praktyczną interpretację tych wytycznych przedstawiono w pracy [3]. Jeśli wymagane jest zmniejszenie ryzyka, to osiąga się to w trzech krokach zwanych triadą bezpieczeństwa:

1) rozwiązania konstrukcyjne bezpieczne same w sobie,

2) techniczne środki ochronne i uzupełniające środki ochronne,

3) informacje dotyczące bezpieczeństwa użytkowania.

Kroki te omówiono w pracy [3] i w normie [2].

Zrozumiałym jest, że im bardziej zmniejszenie ryzyka jest zależne od elementów systemów sterowania związanych z bezpieczeństwem, tym jest wymagana większa odporność tych elementów na defekty. Odporność ta może być wyrażona ilościowo wskaźnikami niezawodności oraz za pomocą struktury odpornej na defekty. Poziom zapewnienia bezpieczeństwa PL stosowany jest w drugim kroku triady bezpieczeństwa. Dalej przedstawiono praktyczne sposoby wyznaczania PL systemu zwłaszcza w sytuacji, gdy użyto podsystemów o nieokreślonych PL.

\section{Specyfikacja funkcji bezpieczeństwa i poziomu bezpieczeństwa}

W celu określenia wymaganego poziomu zapewnienia bezpieczeństwa PLr (ang. required) danej funkcji bezpieczeństwa stosuje się graf ryzyka składający się z ciężkości urazów, częstości narażenia i/lub czasu jego trwania oraz z możliwości uniknięcia zagrożenia lub ograniczenia szkód (rys. 1).

Graf ryzyka jest stosowany tylko do wyznaczenia PLr dla danych funkcji bezpieczeństwa i nie jest stosowany do szacowania ryzyka dla całej maszyny. Zazwyczaj funkcja bezpieczeństwa jest zrealizowana z trzech elementów (rys. 2): czujnika wykrywającego zagrożenie, jednostki logicznej analizującej sygnały z czujnika i podłączonego do jednostki sterującej elementu wykonawczego (np. stycznika wyłączającego niebezpieczny napęd). W tym przypadku 
specyfikacja funkcji bezpieczeństwa mogłaby być zdefiniowana następująco „Zatrzymanie niebezpiecznego napędu przez otwarcie osłony bezpieczeństwa i uniemożliwienie jego uruchomienia do czasu zamknięcia osłony".

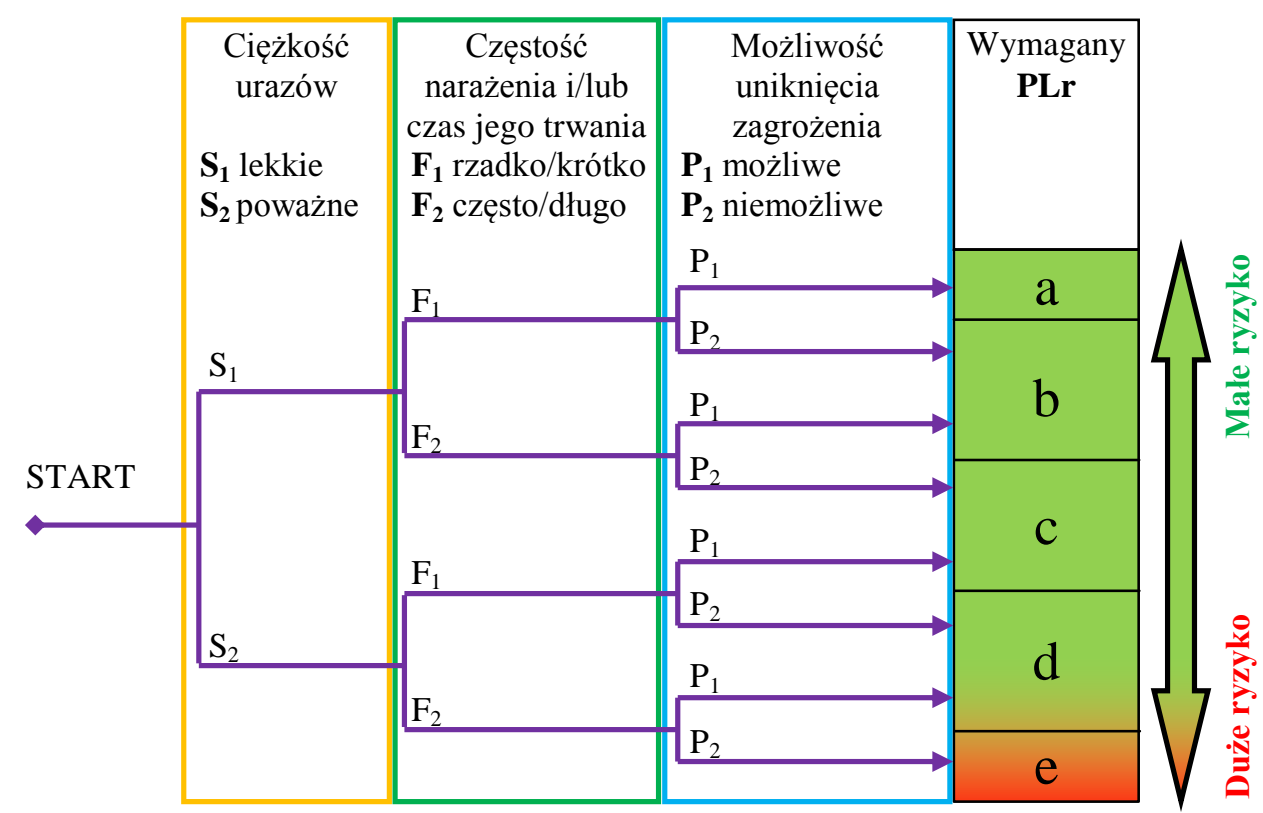

Rys. 1. Graf ryzyka do wyznaczania wymaganego PLr danej funkcji bezpieczeństwa

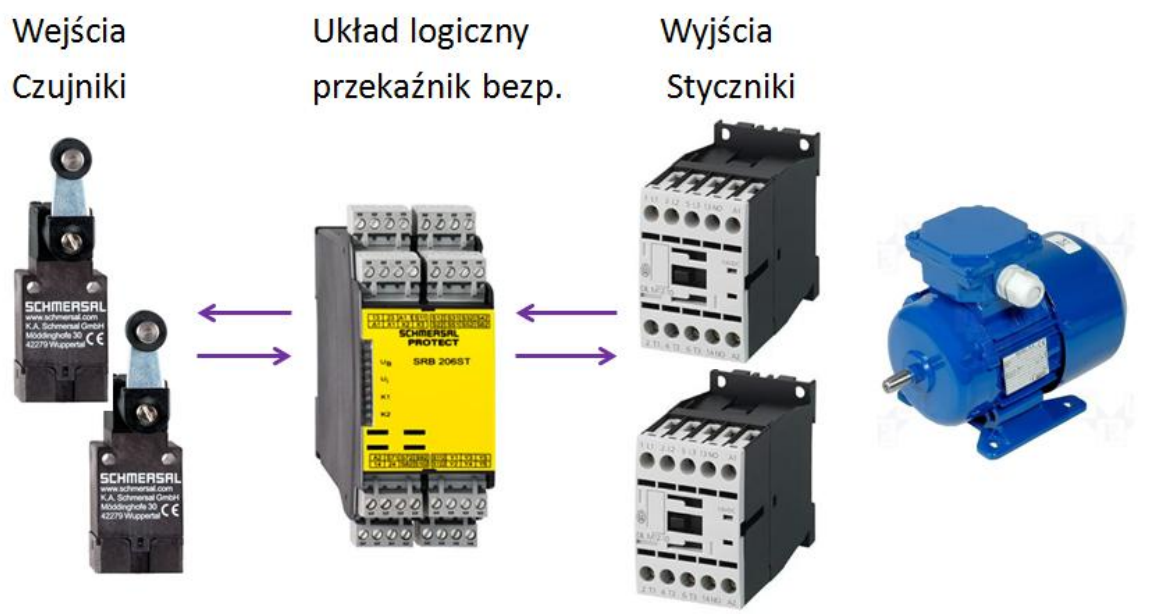

Rys. 2. Podsystemy funkcji bezpieczeństwa zatrzymania niebezpiecznego napędu 
Safety of machinery - determination of performance ...

Bezpieczeństwo maszyn - wyznaczanie poziomu ...

\section{Uzyskany poziom zapewnienia bezpieczeństwa}

PL przyjmuje 5 dyskretnych poziomów: od „a” do „e”, przy czym poziom „e” charakteryzuje się największa niezawodnością i odpornością na defekty. Jeżeli funkcję bezpieczeństwa zrealizowano $\mathrm{z}$ elementów posiadających określone PL to możliwy do uzyskania PL całego systemu wynika z „najsłabszego” PL podsystemu składowego oraz z liczby podsystemów posiadających taki PL (tabela 1).

Tabela 1. Wyznaczenie PL systemu na podstawie znajomości PL podsystemów

\begin{tabular}{|c|c|c|c|}
\hline $\begin{array}{c}\text { Najniższy PL } \\
\text { podsystemu }\end{array}$ & $\begin{array}{c}\text { Liczba podsystemów } \\
\text { posiadających taki PL }\end{array}$ & $\Rightarrow$ & $\begin{array}{c}\text { Maks. możliwy do } \\
\text { uzyskania PL systemu }\end{array}$ \\
\hline \multirow{3}{*}{$\mathrm{a}$} & $>3$ & $\Rightarrow$ & niedozwolony \\
\cline { 2 - 4 } & $\leq 3$ & $\Rightarrow$ & $\mathrm{a}$ \\
\hline \multirow{3}{*}{$\mathrm{b}$} & $>2$ & $=>$ & $\mathrm{a}$ \\
\cline { 2 - 4 } & $\leq 2$ & $=>$ & $\mathrm{b}$ \\
\hline \multirow{2}{*}{$\mathrm{c}$} & $>2$ & $=>$ & $\mathrm{b}$ \\
\cline { 2 - 4 } & $\leq 2$ & $=>$ & $\mathrm{c}$ \\
\hline \multirow{2}{*}{$\mathrm{d}$} & $>3$ & $=>$ & $\mathrm{c}$ \\
\cline { 2 - 4 } & $\leq 3$ & $\Rightarrow$ & $\mathrm{d}$ \\
\hline \multirow{2}{*}{$\mathrm{e}$} & $>3$ & $=>$ & $\mathrm{d}$ \\
\cline { 2 - 4 } & $\leq 3$ & & $\mathrm{e}$ \\
\hline
\end{tabular}

W przypadku, gdy PL nie jest znany dla wszystkich podsystemów, należy najpierw samodzielnie określić poziom bezpieczeństwa takiego podsystemu. Określenie poziomu zapewnienia bezpieczeństwa dla podsystemu uzyskuje się na podstawie:

- struktury układu (kategorii),

- wartości średniego czasu pomiędzy niebezpiecznymi uszkodzeniami (MTTFd),

- pokrycia diagnostycznego (DC),

- odporności na uszkodzenia spowodowane wspólną przyczyną (CCF).

\section{Struktura układu - kategorie}

Istnieje 5 kategorii: $\mathrm{B}, 1,2,3,4$. Układy jednokanałowe mogą być kategorii $\mathrm{B}$ oraz 1. Kategoria 2 charakteryzuje układ jednokanałowy z monitorowaniem defektów w podsystemach. Kategorie 3 i 4 dotyczą układów wielokanałowych (redundantnych). W tabeli 2 przedstawiono porównanie poszczególnych kategorii. 


\section{Średni czas pomiędzy niebezpiecznymi uszkodzeniami MTTFd}

W załączniku C normy PN-EN ISO13849-1 podano 4 metody obliczania/szacowania MTTFd dla pojedynczych części:

1) Metoda dobrych praktyk inżynierskich,

2) Metoda dla części hydraulicznych,

3) Dla części pneumatycznych, mechanicznych i elektromechanicznych,

4) Dla części elektrycznych.

$\mathrm{W}$ przypadku pierwszej metody $\mathrm{w}$ tabeli podano typowe wartości MTTFd $\mathrm{w}$ latach dla części mechanicznych i hydraulicznych. Dla części pneumatycznych i elektrycznych podano parametr $B_{10 d}$, który określa ilość cykli, po których niebezpiecznemu uszkodzeniu ulegnie $10 \%$ badanej populacji.

Tabela 2. Skrócony opis kategorii bezpieczeństwa

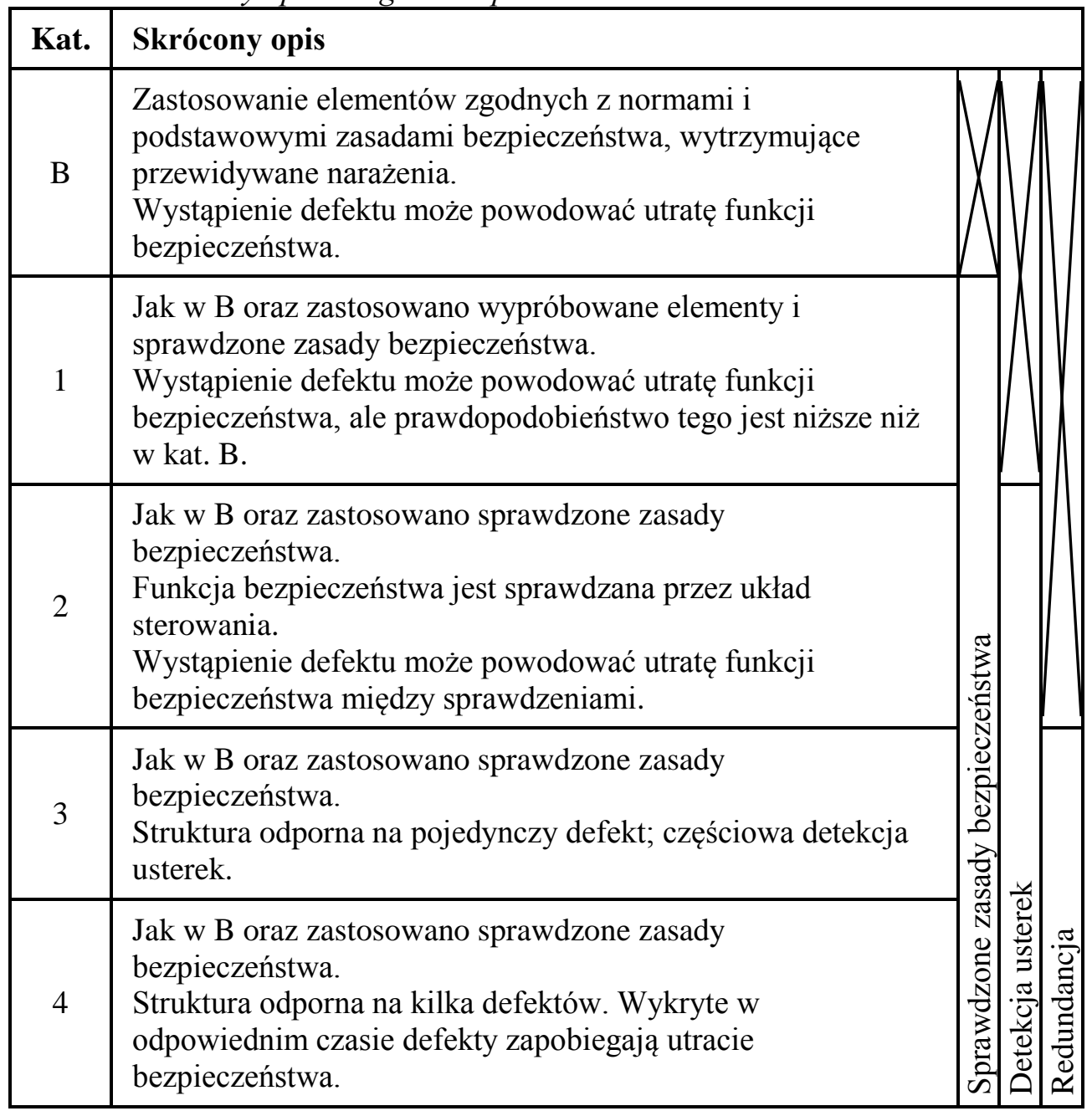


Safety of machinery - determination of performance ...

Bezpieczeństwo maszyn - wyznaczanie poziomu ...

Dla części hydraulicznych, w metodzie drugiej podano sztywną wartość MTTFd=150 lat.

MTTFd dla części pneumatycznych, mechanicznych i elektromechanicznych $\mathrm{w}$ metodzie trzeciej wyznaczany jest $\mathrm{z}$ parametru $\mathrm{B}_{10 \mathrm{~d}} \mathrm{ze}$ wzoru:

$$
\mathrm{MTTFd}=\frac{\mathrm{B}_{10 \mathrm{~d}}}{0,1 \cdot \mathrm{n}_{\mathrm{op}}}
$$

gdzie:

$$
\begin{aligned}
& \mathrm{n}_{\mathrm{op}}=\frac{\mathrm{d}_{\mathrm{op}} \cdot \mathrm{h}_{\mathrm{op}} \cdot 3600 \frac{\text { sek. }}{\text { godz. }}}{\mathrm{t}_{\text {cycle }}} \\
& \mathrm{n}_{\mathrm{op}}-\text { średnia ilość cykli na rok, } \\
& \mathrm{d}_{\mathrm{op}}-\text { średni czas pracy w dniach na rok, } \\
& \mathrm{h}_{\mathrm{op}}-\text { średni czas pracy w godzinach na dzień, } \\
& \mathrm{t}_{\text {cycle }}-\text { średni czas pomiędzy rozpoczęciem dwóch kolejnych cykli } \\
& \quad \text { w sekundach na cykl. }
\end{aligned}
$$

Oszacowanie MTTFd dla elementów elektronicznych w metodzie 4-tej polega na odczycie $\mathrm{z}$ tabel wartości MTTFd dla elementów (tranzystorów, diod, kondensatorów itd.), z których zbudowany jest dany kanał. Czasy poszczególnych elementów w obrębie kanału należy następnie zsumować wg zależności:

$$
\frac{1}{\operatorname{MTTFd}_{\mathrm{CH} 1}}=\frac{1}{\operatorname{MTTFd}_{\mathrm{el} 1}}+\cdots+\frac{1}{\operatorname{MTTFd}_{\mathrm{el}} \mathrm{n}}=\sum_{\mathrm{i}=1}^{\mathrm{n}} \frac{1}{\operatorname{MTTFd}_{\mathrm{el}} \mathrm{i}}
$$

Jeśli czasy MTTFd poszczególnych kanałów w systemie redundantnym są różne to należy dokonać symetryzacji wg zależności:

$$
M T T F d=\frac{2}{3}\left(M T T F d_{C H 1}+M T T F d_{C H 2}-\frac{1}{\frac{1}{M T T F d_{C H 1}}+\frac{1}{M T T F d_{C H} 2}}\right)
$$

Do dalszej analizy bierze się czas uzyskany ze wzoru (3).

Średni czas pomiędzy niebezpiecznymi uszkodzeniami MTTFd jest podzielony na trzy zakresy przedstawione w tabeli 3 . 
Tabela 3. Zakresy MTTFd dla kanatu

\begin{tabular}{|l|c|}
\hline Oznaczenie & Zakres dla kanalu \\
\hline Krótki & 3 lata $\leq$ MTTFd $<10$ lat \\
\hline Średni & 10 lat $\leq$ MTTFd $<30$ lat \\
\hline Długi & 30 lat $\leq$ MTTFd $\leq 100$ lat \\
\hline
\end{tabular}

\section{Pokrycie diagnostyczne DC}

Usterki można podzielić na bezpieczne i niebezpieczne. Stosunek wykrywanych uszkodzeń niebezpiecznych $\lambda_{\mathrm{DD}}$ do wszystkich uszkodzeń niebezpiecznych (wykrywanych $\lambda_{\mathrm{DD}}$ i niewykrywanych $\lambda_{\mathrm{DU}}$ ) określa pokrycie diagnostyczne:

$$
D C=\frac{\Sigma \lambda_{D D}}{\Sigma \lambda_{D D}+\Sigma \lambda_{D U}}
$$

W załączniku E normy [1] stabelaryzowano rozmaite metody monitorowania defektów w podsystemach z podaniem typowych wartości DC w procentach. Np. jeśli monitoruje się główne styki stycznika przy pomocy sprzężonych mechanicznie styków pomocniczych, to przyjmuje się DC=99\%. Pokrycie diagnostyczne DC przyjmuje trzy zakresy przedstawione w tabeli 4.

Tabela 4. Zakresy pokrycia diagnostycznego DC

\begin{tabular}{|l|c|}
\hline Oznaczenie & Zakres \\
\hline Niskie & $60 \% \leq \mathrm{DC}<90 \%$ \\
\hline Średnie & $90 \% \leq \mathrm{DC}<99 \%$ \\
\hline Wysokie & $\mathrm{DC} \geq 99 \%$ \\
\hline
\end{tabular}

\section{Odporność na uszkodzenia spowodowane wspólną przyczyną CCF}

Parametr CCF określa odporność na uszkodzenia różnych podsystemów spowodowane pojedynczym zdarzeniem, przy czym uszkodzenia te nie są wzajemnymi następstwami. W tabeli 5 zebrano środki/wymagania chroniące przed tego typu uszkodzeniami. Jeśli zastosowano $\mathrm{w}$ podsystemie dany środek zapobiegawczy to przyznaje się pełną liczbę punktów (nie przyznaje się punktów 
Safety of machinery - determination of performance ...

Bezpieczeństwo maszyn - wyznaczanie poziomu ...

częściowych!). Punkty następnie się sumuje. Maksymalna ilość punktów wynosi 100. Odporność na CCF jest zadawalająca, gdy suma punktów jest większa od 65 punktów włącznie. Sprawdzenie odporności na CCF wymagane jest tylko dla kategorii 2, 3 i 4.

Tabela 5. Odporność na CCF

\begin{tabular}{|l|l|r|}
\hline \multicolumn{2}{|l|}{ ŚRODEK / WYMAGANIE } & Punkty \\
\hline Odseparowanie & $\begin{array}{l}\text { Odseparowanie obwodów sygnałowych (przewodów } \\
\text { elektrycznych, hydraulicznych, cięgien } \\
\text { mechanicznych), dostateczne odstępy powierzchniowe i } \\
\text { powietrzne }\end{array}$ & 15 \\
\hline Zróżnicowanie & $\begin{array}{l}\text { Różne technologie lub fizyczne zasady, np. } \\
\text { pierwszy kanał programowalny a drugi kanał } \\
\text { sprzętowy; } \\
\text { pomiar cyfrowy i analogowy; elementy różnych } \\
\text { producentów }\end{array}$ & 20 \\
\hline $\begin{array}{l}\text { Projekt } \\
\text { zastosowanie } \\
\text { doświadczenie }\end{array}$ & $\begin{array}{l}\text { Ochrona przed przepięciem, przeciążeniem, } \\
\text { zwiększonym ciśnieniem, np. w mechanice sprzęgła } \\
\text { przeciążeniowe }\end{array}$ & 15 \\
\cline { 2 - 3 } & Zastosowanie wypróbowanych elementów & 5 \\
\hline $\begin{array}{l}\text { Ocena } \\
\text { Analiza }\end{array}$ & $\begin{array}{l}\text { Przeprowadzenie analizy rodzajów i skutków } \\
\text { uszkodzeń (FMEA), aby uniknąć uszkodzeń } \\
\text { spowodowanych wspólną przyczyną w projektowaniu }\end{array}$ & $\begin{array}{l}\text { Testy systemu pod kątem wpływu temperatury, } \\
\text { wstrząów, wibracji, wilgotności, substancji } \\
\text { korozyjnych itp. }\end{array}$ \\
\hline $\begin{array}{l}\text { Kompetencje } \\
\text { Szkolenia }\end{array}$ & $\begin{array}{l}\text { Szkolenie projektantów w kierunku pojmowania } \\
\text { przyczyn i skutków uszkodzeń spowodowanych } \\
\text { wspólną przyczyną }\end{array}$ & $\begin{array}{l}\text { EMC (dla elektryki), czystość medium (dla hydrauliki i } \\
\text { pneumatyki), współczynnik bezpieczeństwa (dla } \\
\text { mechaniki) }\end{array}$ \\
\cline { 2 - 3 } $\begin{array}{l}\text { Wpływy } \\
\text { śodowiska }\end{array}$ & 5 \\
\hline
\end{tabular}

\section{Określenie PL podsystemu}

Mając wyznaczone wszystkie cztery parametry można przejść do określenia PL podsystemu korzystając z rys. 3. Np. jeżeli architektura układu jest wielokanałowa i $\mathrm{CCF} \geq 65$ oraz pokrycie diagnostyczne jest na poziomie średnim, to przy czasie 
MTTFd=długi osiągnięte PL umiejscowione jest na pograniczu PL d/e. Jeśli jest to zasadne, w celu dokładnego odczytu, należy skorzystać $\mathrm{z}$ wartości stabelaryzowanych $\mathrm{w}$ tabeli K.1 [1] uwzględniających dodatkowy parametr $\mathrm{PFH}_{\mathrm{D}}$ (prawdopodobieństwo niebezpiecznego uszkodzenia na godzinę). Lecz jeśli „słabsze” rozwiązanie jest satysfakcjonujące, to można poprzestać na jego przyjęciu.

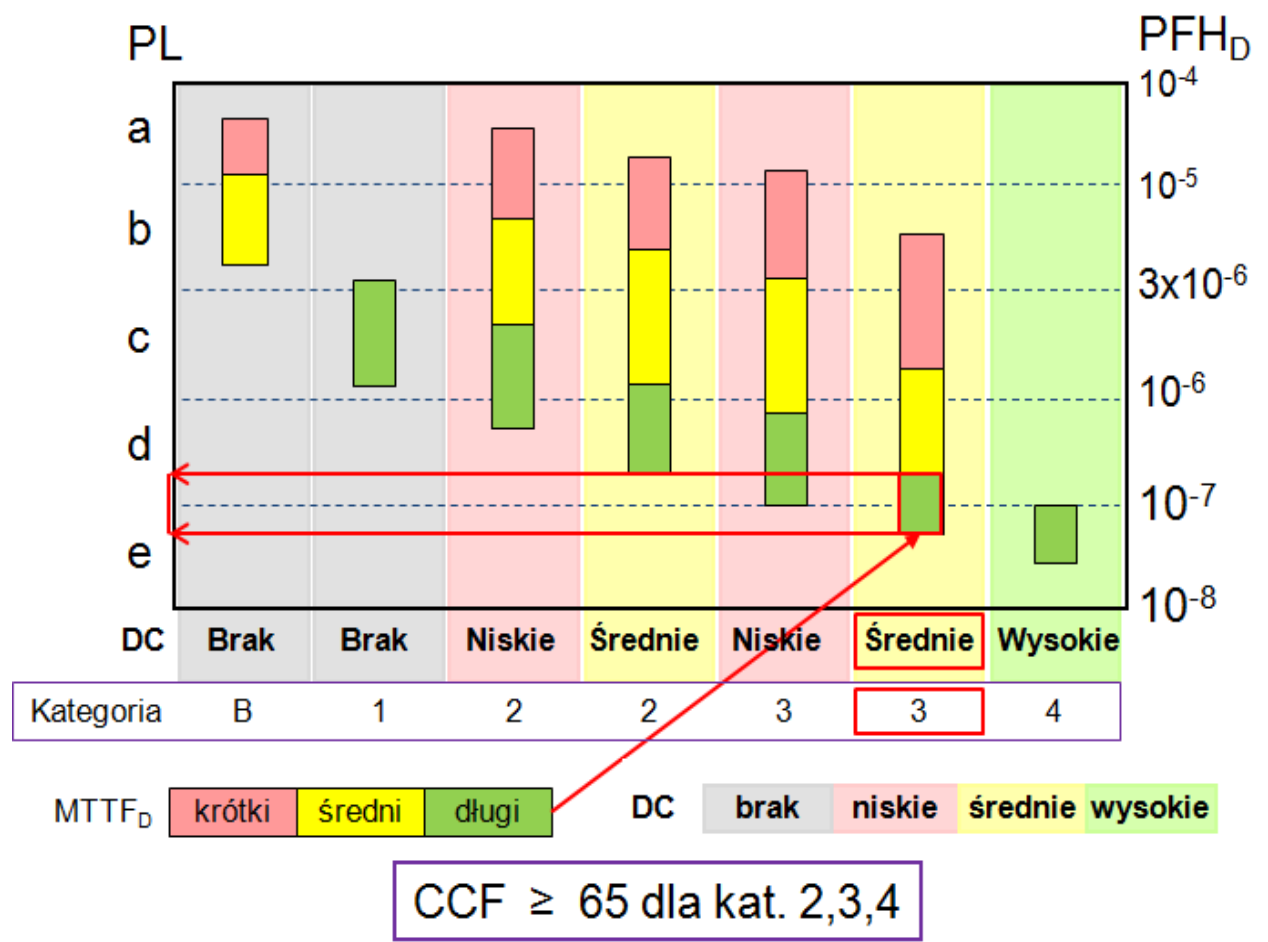

Rys. 3. Wyznaczanie PL dla podsystemu

W celu określenia PL całego systemu korzysta się jak poprzednio z tabeli 1. Jeśli otrzymany PL $\mathrm{z}$ tabeli 1 jest większy lub równy od wymaganego dla funkcji bezpieczeństwa PLr, to stwierdza się, że układ bezpieczeństwa spełnia właściwe wymagania i charakteryzuje się odpowiednią niezawodnością i odpornością na defekty.

\section{Podsumowanie}

Trudnością w implementacji dyrektywy maszynowej i wymienionych norm jest to, że wprowadzają one nowe, angielskojęzyczne pojęcia nieznane do tej pory szerokiemu gronu użytkowników. Obecnie w Komitecie Technicznym KT158 Polskiego Komitetu Normalizacyjnego trwają prace nad przetłumaczeniem tych norm na język polski. 
Safety of machinery - determination of performance ...

Bezpieczeństwo maszyn - wyznaczanie poziomu ...

\section{Literatura}

[1] PN-EN ISO 13849-1:2008+AC:2009 Bezpieczeństwo maszyn - Elementy systemów sterowania związane z bezpieczeństwem - Część 1: Ogólne zasady projektowania

[2] PN-EN ISO 12100:2011 Bezpieczeństwo maszyn - Ogólne zasady projektowania - Ocena ryzyka i zmniejszanie ryzyka

[3] Kasprzyczak L.: Program certyfikacji wyrobów na zgodność z dyrektywą maszynową w Centrum Badań i Certyfikacji Instytutu EMAG. Mechanizacja i Automatyzacja Górnictwa, 6(496)/2012, ss.13-20

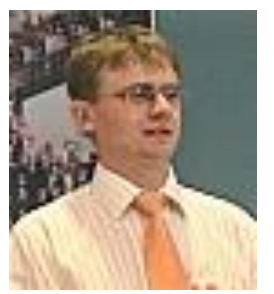

dr inj. Leszek Kasprzyczak - adiunkt $w$ Instytucie Technik Innowacyjnych EMAG, specjalista $w$ zakresie mechatroniki, systemów pomiarowych, bezpieczeństwa funkcjonalnego oraz budowy i eksploatacji maszyn. 


\title{
ASSESSMENT OF THE INFLUENCE OF THE HUMAN FACTOR ON SAFETY OF THE TRANSPORTATION PROCESS
}

\section{OCENA WPLYWU CZYNNIKA LUDZKIEGO NA BEZPIECZEŃSTWO PROCESU TRANSPORTOWEGO}

\author{
Piotr Bojar $^{1}$, Maciej Woropay ${ }^{2}$, Mirosław Szubartowski ${ }^{3}$, Michal \\ Bacior $^{4}$ \\ 1 - Uniwersytet Technologiczno Przyrodniczy w Bydgoszczy \\ 2 - Insytut Techniczny Wojsk Lotniczych w Warszawie \\ 3,4 - Wyższa Szkoła Techniki i Przedsiębiorczości we Włocławku \\ e-mail:1-p-bojar@utp.edu.pl;2,3,4-zem@utp.edu.pl;
}

\begin{abstract}
Safety of the transport process is a criterion of top priority for a transportation system operation and maintenance. It is of special importance in case of public municipal transportation. Systems of this type operate in specific road conditions: increased intensity of traffic during a day and night, a big number of pedestrians as well as drivers of other vehicles. In such conditions the human factor and its impact on the transport system operation is of key importance. A human can be involved in the transportation system as a driver, passenger, pedestrian, or in another way (cyclist, motorcyclist). Improper behavior of people account for $36 \%$ - $46 \%$ of road accident causes defined as undesirable events occurred within the space of the road. In this paper there has been mad an attempt to evaluate the transportation system from the point of view of people present in the transportation system and its environment.
\end{abstract}

Keywords: safety working, undesirable event

Streszczenie: Bezpieczeństwo realizowanego procesu transportowego jest priorytetowym kryterium działania systemów transportowych. Szczególnie ważne jest to w przypadku systemów zbiorowego transportu miejskiego. Systemy tego typu podlegają szczególnym warunkom ruchu: wzmożone natężenie ruchu w ciagu doby, duża liczba pieszych uczestników ruchu drogowego jak również kierowców pojazdów obcych. W takich warunkach szczególnie istotnym jest czynnik ludzki $i$ jego oddziaływania na system transportowy. Człowiek $w$ systemie transportowym usytuowany może być jako kierowca pojazdu, jego pasażer, pieszy w otoczeniu lub inny uczestnik ruchu (rowerzysta, motocyklista). Niewtaściwe oddziaływania ludzi stanowia $36 \%$ a $46 \%$ przyczyne powstawania zdarzen drogowych definiowanych jako zdarzenia niepożadane zaistniałe $w$ obszarze przestrzeni drogowej. W pracy podjęto próbę oceny systemu transportowego z punktu widzenia działań ludzi usytuowanych $w$ systemie i jego otoczeniu.

Słowa kluczowe:bezpieczeństwo działania, zdarzenie niepożądane 


\section{Introduction}

Transportation systems are socio-technical systems whose operation safety depends on different forcing factors. In literature $[1,2,3]$ these factors are divided into three sets: 1-those which are connected with the vehicle technical state, 2 - external ones, connected with the environmental impact, 3 - anthropotechnical factors related to the behavior of people involved in the system and its environment. The role of humans in the systems of municipal transportations is of key importance due to the functions they perform. According to the role people play in the transportation system, they may be divided into:

- dispatchers - decision makers responsible for accomplishment of the transportation process,

- diagnostician - whose task is to maintain or return the vehicle to the desirable state.

- driver - directly responsible for safety of the transported passengers.

- passenger - using the services provided by a transportation system.

People are also present in the transportation system environment which means that they do not belong to the system but they remain in a given relation with it. The people who are present in the system are classified into:

- users of other transport means (vehicles, motorbikes, bicycles, and others),

- pedestrians and people waiting at bus stops.

Safety of the transportation process depends on the behavior of these people. Behaviors of people can be divided into two subsets 1 - conscious and intended, 2 unconscious, resulting from individual traits and mental and physical health. The authors have made an attempt to identify human behaviors and evaluate the impact of their actions on the transportation process safety.

\section{Analysis of selected threats connected with the behavior of humans.}

Improper behaviors of people involved in transportation systems cause undesirable events, the effect of whose are material losses and loss of health or life of people who are participants of the traffic. In table 1 there are results of probability values of occurrence of undesirable events caused by improper actions of people. As the presented data shows the improper behaviors of vehicle drivers are featured by the highest probability of causing an undesirable event. In table 2 there are values of probabilities of occurrence of an undesirable event whose result is death or injury of a road traffic participant. As the data contained in table 2 shows, also the actions of drivers are characterized by the highest probability value of an undesirable event occurrence.

It must be emphasized that the probability of occurrence of a fatal traffic accident due to improper behavior of passengers is almost two times higher than the probability of sustaining injury by road traffic participants. 
Assessment of the influence of the human factor on safety ... Ocena wptywu czynnika ludzkiego na bezpieczeństwo ...

Table 1. Probability of occurrence of a road accident due to improper behavior of people present in the transportation system or its environment.

\begin{tabular}{|l|c|}
\hline \multicolumn{1}{|c|}{ Improper behaviour } & $\begin{array}{c}\text { Probability of occurrence of traffic } \\
\text { accident }\end{array}$ \\
\hline Vehicle drivers & 0,8164 \\
\hline Pedestrians & 0,1811 \\
\hline Vehicle passengers & 0,0024 \\
\hline
\end{tabular}

Table 2. Probability of occurrence of a fatal road accident or sustaining injuries by people involved in it.

\begin{tabular}{|l|c|c|}
\hline Improper behavior & Fatalities & Injured \\
\hline Vehicle drivers & 0,8005 & 0,8663 \\
\hline Pedestrians & 0,1961 & 0,1320 \\
\hline Vehicle passengers & 0,0034 & 0,0018 \\
\hline
\end{tabular}

\section{Causes of occurrence of undesirable road events due to improper behavior of vehicle drivers}

On the basis of data collected for the study [5], the values of probabilities of occurrence of undesirable road events have been calculated. The most frequent causes of road accidents by fault of drivers have been presented in table 3 and in fig. 1. As the data shows, the most frequent cause of traffic accidents is improper behavior of the vehicle drivers involving: failing to adjust speed to road conditions, failing to give way, and wrong attitude toward pedestrians.

The data contained in table 3 can be divided into two subsets of causes of improper behavior of drivers that is:

- improper steering the vehicle $(1 \div 3,6 \div 16)$, described by the probability of occurrence of event $\mathrm{P}\left(\mathrm{A}_{1}\right)$,

- improper health condition of the driver $(4 \div 5)$, with a probability of $\mathrm{P}\left(\mathrm{A}_{2}\right)$ occurrence.

As it can be seen, the probability of occurrence of an undesirable road event due to improper behavior of drivers, resulting from their poor health condition is 0.027 , and is approximately 36 times lower than the probability of occurrence of an undesirable road event as a result of improper vehicle steering $\mathrm{P}(\mathrm{A} 1)=0,973$. This involves a necessity to take up actions aiming at improving the drivers' skills. 
Piotr Bojar, Maciej Woropay, Mirosław Szubartowski, Michał Bacior

Table 3 The most frequent causes of occurrence of undesirable traffic events by fault of drivers.

\begin{tabular}{|r|l|c|}
\hline No. & \multicolumn{1}{|c|}{ Improper behavior of drivers } & $\mathrm{P}(\mathrm{A})$ \\
\hline 1 & Disrespecting traffic signs and signals & 0,0032 \\
\hline 2 & Sudden braking & 0,0037 \\
\hline 3 & Driving without required lighting & 0,0045 \\
\hline 4 & Limited psychomotor efficiency & 0,0133 \\
\hline 5 & Tiredness, falling asleep & 0,0137 \\
\hline 6 & Disobeying traffic lights & 0,0150 \\
\hline 7 & Improper reversing & 0,0194 \\
\hline 8 & Improper passing from the opposite direction & 0,0207 \\
\hline 9 & Improper passing stationary objects & 0,0322 \\
\hline 10 & Driving on the wrong side of the road & 0,0326 \\
\hline 11 & Improper turning & 0,0464 \\
\hline 12 & Failing to keep safe distant from other vehicles & 0,0501 \\
\hline 13 & Improper overtaking & 0,0798 \\
\hline 14 & Improper behavior toward pedestrians & 0,1026 \\
\hline 15 & Disobeying the priority of way & 0,2533 \\
\hline 16 & Failing to adjust speed to road conditions & 0,3096 \\
\hline
\end{tabular}

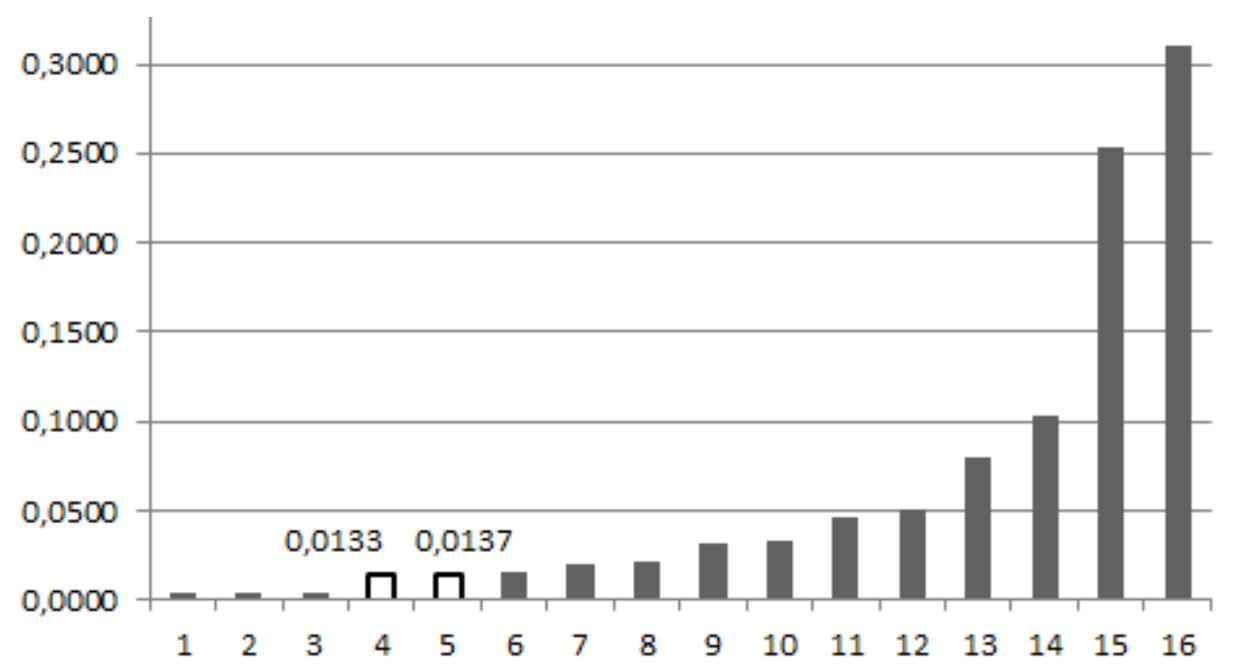

Fig. 1 Values of probability of occurrence of undesirable events due to drivers' behavior. 
Assessment of the influence of the human factor on safety ...

Ocena wplywu czynnika ludzkiego na bezpieczeństwo ...

\section{Causes of occurrence of undesirable events due to improper behavior of the passengers.}

Improper behaviors of the transport means passengers are rarely the cause of occurrence of traffic accidents in transportation systems. These behaviors are as follows:
a. distracting the driver's attention
b. aggression toward the driver,
c. jumping out of the vehicle
d. improper behaviour on the bus while riding,
e. other reasons

The above presented behaviours of passengers refer to public transportation systems. Apart from the above listed improper behaviours of passengers in systems of public transportation, there can be distinguished purposeful and conscious behaviours intended to damage the means of transport (devastation). In public transport means devastations account for approximately $30 \%$ of all undesirable events and generate nearly $20 \%$ of all the repair costs.

\section{Causes of occurrence of undesirable events due to improper behavior of pedestrians.}

In the environment of a transportation system the humans can perform the function of drivers, cyclists, pedestrians and those who wait at bus stops. Improper behavior of pedestrians account for the second group of causes of occurrence of traffic accidents. In result of improper behaviors of pedestrians as many as 25 of them die in 100 traffic accidents.

In table 4 there are values of probabilities concerning the causes of occurrence of undesirable events due to improper behavior of pedestrians. According to the data from table 4, improper behaviors of pedestrians which most frequently lead to undesirable events include: reckless entering the road in front of a riding bus, improper crossing the street and thoughtless entering the road from behind a vehicle or another object.

Table 4. The most frequent causes of road accidents by fault of people present in the environment of the transportation system

\begin{tabular}{|c|l|c|}
\hline Lp. & Improper behaviour of pedestrians & $\mathrm{P}(\mathrm{B})$ \\
\hline 1 & Walking on the track age & 0,00162 \\
\hline 2 & Jumping into a moving vehicle & 0,00238 \\
\hline 3 & Walking on the wrong side of the road & 0,03711 \\
\hline 4 & Leaving children without care & 0,06058 \\
\hline 5 & $\begin{array}{l}\text { Reckless entering the road from behind a vehicle or } \\
\text { another object. }\end{array}$ & 0,10861 \\
\hline 6 & Improper crossing the street & 0,31826 \\
\hline 7 & Reckless entering the road in front of a riding bus. & 0,47144 \\
\hline
\end{tabular}


In fig. 2 there are presented values of probability of occurrence of undesirable events due to improper behavior of people present in the environment of a transportation system. As the data shows, improper behaviors of pedestrians with the highest probability value include improper crossing the street, the sum of which being $\mathrm{P}(\mathrm{B} 5)+\mathrm{P}(\mathrm{B} 6)+\mathrm{P}(\mathrm{B} 7)=0,898$, and account for nearly $90 \%$ of causes of occurrence of undesirable events by fault of pedestrians.

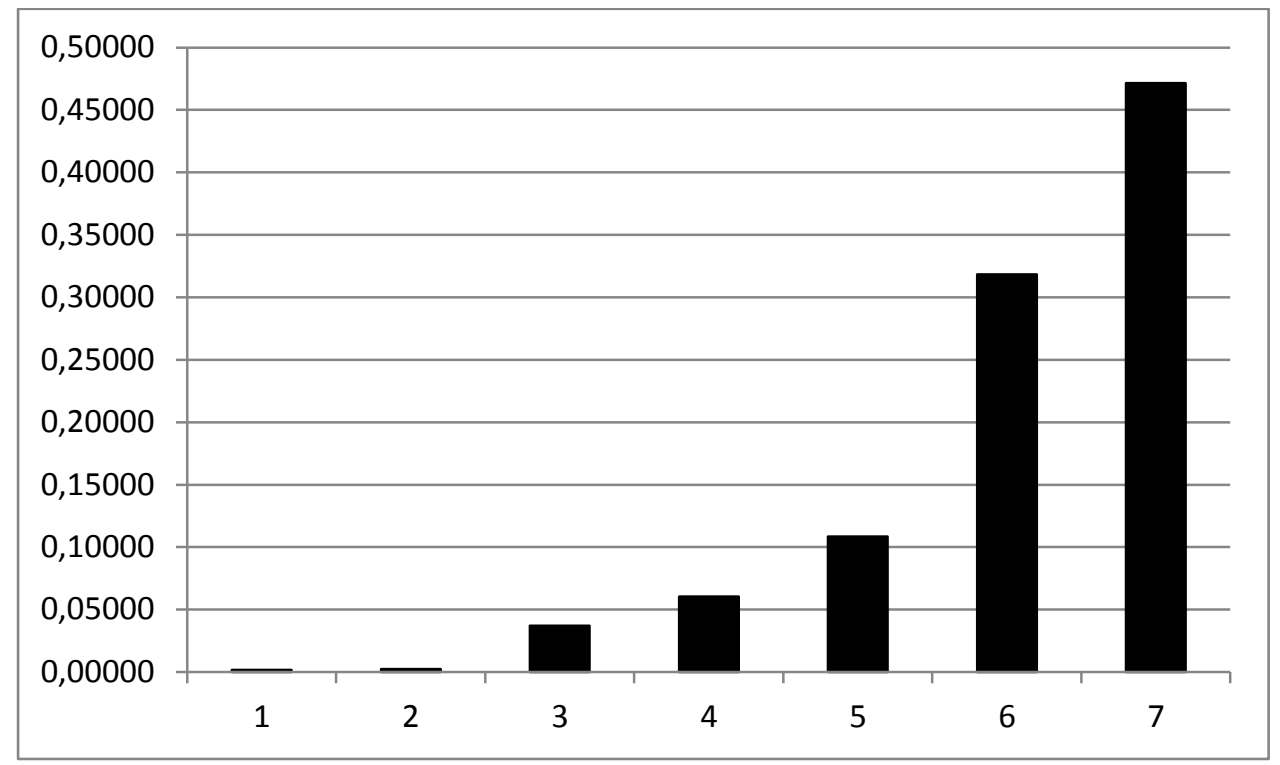

Fig. 2. Values of probability of occurrence of undesirable events due to improper behaviors of pedestrians

\section{Causes of occurrence of undesirable events due to improper behaviors of people present in the subsystem of ensuring efficient operation of vehicles.}

According to works [1.3], the technical state of a vehicle has an influence on the safety of transport tasks. In systems of public transportation, maintenance of vehicles is the responsibility of people who work in the subsystem ensuring efficient operation of vehicles - diagnosticians and mechanics. Their duties include performance of scheduled and current services and repairs of transport means. A repair is a series of organizational -technical activities aiming at maintenance of vehicles through regulation and exchange of damaged elements.

According to work [3] the repair related errors are the main cause of occurrence of a vehicle failure. The failures impair the vehicle technical state which accounts for nearly $30 \%$ of occurrence of undesirable traffic events in transportation systems. In 
Assessment of the influence of the human factor on safety ...

Ocena wplywu czynnika ludzkiego na bezpieczeństwo ...

work [3] there have been presented the most frequent repair errors such as:

- application of unsuitable material,

- regulation errors,

- repair technology errors,

- application of mismatched spare part,

- application of a damaged part.

- application of a part made of unsuitable material,

- application of a part with a hidden defect,

- application of a part with wrong dimensions,

- montage errors,

- post repair pollution.

\section{Improper actions of drivers as factors leading to occurrence of undesirable traffic events.}

The extent to which the behavior of people affects a transportation system and the tasks it performs, depends on the position they occupy in the system. In figure 3 there are examples of improper behaviors of drivers leading to occurrence of an undesirable traffic event.

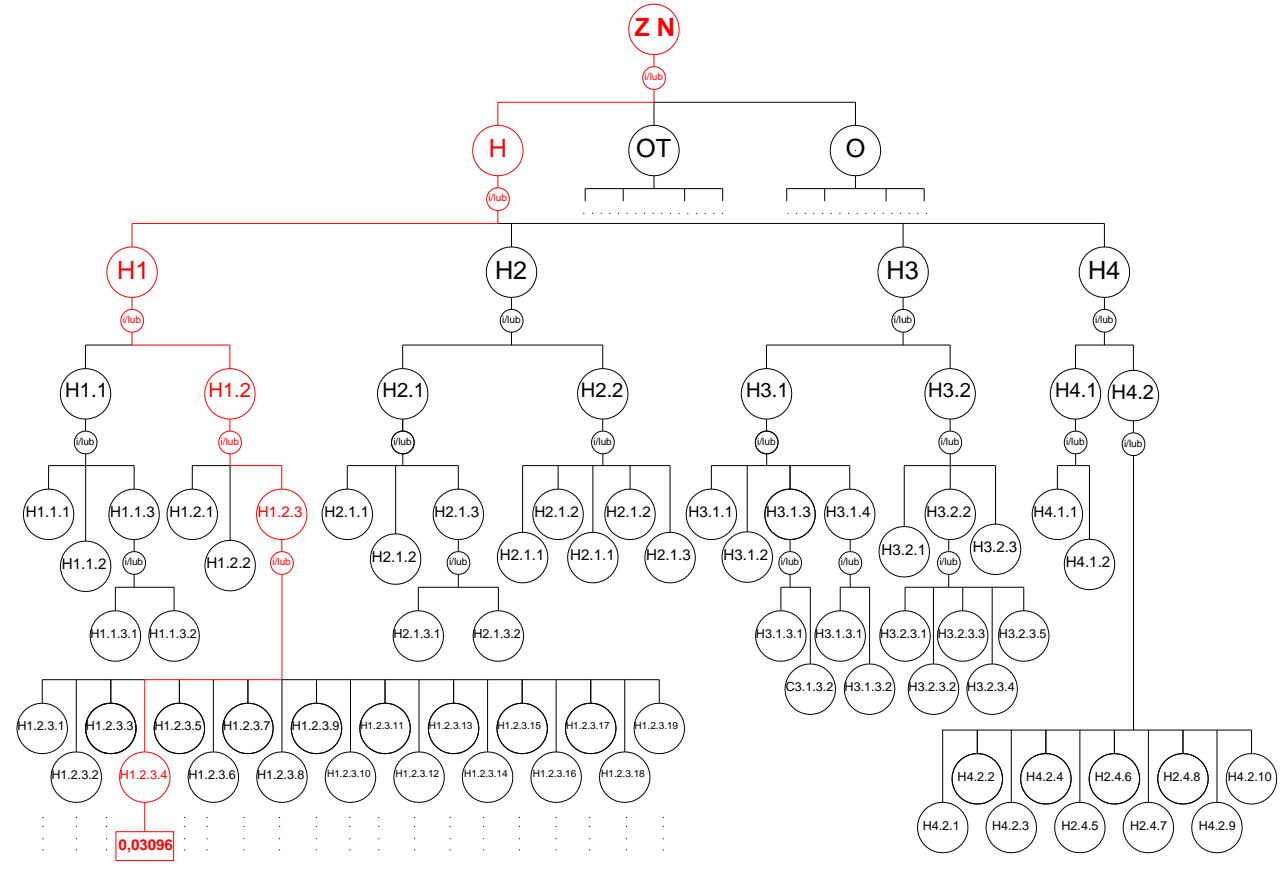

Fig.3 Graphic presentation of the impact of an elementary event on occurrence of an undesirable event. 
In fig.3. there has been presented an influence of one of possible behaviors of a driver on occurrence of an undesirable event. As it can be seen, an undesirable event UE happened in result of improper behavior of a human $\mathrm{H}$. The cause of the event was improper behavior of a driver $\mathrm{H} 1$ which occurred in result of his/her poor mental condition $\mathrm{H} 1.2$, which in consequence led to breaking traffic regulations H1.2.3. Braking traffic regulations involved failing to adjust speed to road conditions H1.2.3.4.

Elementary events are such which initiate occurrence of undesirable events (accidents and collisions). In the figure there has been presented one 'path' from elementary event (H1.2.3.4) to a top event (TE). It results from the fact that a collision/ accident occurred in the effect of breaking traffic regulations by a driver and failing to adjust speed to road conditions. Each of the elementary events is matched with the probability of its occurrence $\mathrm{P}(\mathrm{C} 1.2 .3 .4)=0,3096$. The top event can be initiated by a few simultaneous elementary events connected with the driver's state of health and disrespecting by him/her traffic regulations.

In fig. 3 the following denotations have been accepted:

UE - undesirable event (road accident in the analyzed transportation system),

$\mathrm{H}$ - the cause of the event was improper behavior of people,

OT - the cause of undesirable event was impaired technical condition of a vehicle,

$\mathrm{O} \quad$ - the cause of undesirable event was the impact of external factors

Causes of occurrence of undesirable events due to improper behaviors:

H1 Drivers and their:

H1.1 Physical condition:

H1.1.1 Impaired vision

H1.1.2 Impaired hearing,

H1.1.3 Disease

H1.1.3.1 Raised body temperature,

H1.1.3.2 Raised blood pressure,

H1.2 Mental condition:

H1.2.1 Level of intelligence,

H1.2.2 Driving while being in poor mental condition,

H1.2.3 Improper behaviors including :

H1.2.3.1 driving while being under the influence of alcohol,

H1.2.3.2 driving while being under the influence of drugs, 
Assessment of the influence of the human factor on safety ...

Ocena wpływu czynnika ludzkiego na bezpieczeństwo ...

H1.2.3.3 driving while being intoxicated by medicines impairing motoric abilities,

H1.2.3.4 failing to adjust speed to the conditions on the road,

H1.2.3.5 failing to give way,

H1.2.3.6 improper overtaking,

H1.2.3.7 improper passing stationary objects,

H1.2.3.8 improper passing from opposite direction,

H1.2.3.9 improper going through zebra crossings,

H1.2.3.10 improper turning,

H1.2.3.11 improper braking and parking,

H1.2.3.12 improper reversing,

H1.2.3.13 driving on the wrong side of the road,

H1 2.3.14 entering a crossroads at red light,

H1.2.3.15 disrespecting traffic regulations and signals,

H1.2.3.16 failing to keep safe distance from other vehicles,

H1.2.3.17 sudden braking,

H1.2.3.18 driving without required lighting,

H1.2.3.19 driving a vehicle with impaired serviceability,

H2 Passengers and their:

H2.1 Physical health:

H2.1.1 impaired vision,

H2.1.2 impaired hearing,

$\mathrm{H} 2.1 .3$ health disorders:

H2.1.3.1 raised body temperature,

H2.1.3.2 raised blood pressure,

H2.2 Mental health:

H2.2.1 level of intelligence,

H2.2.2 improper behavior in the vehicle,

H2.2.3 aggression toward the driver,

H2.2.4 distracting the driver's attention,

H2.2.5 limiting the driver's visibility,

H3 Pedestrians and their:

H3.1 Physical health:

H3.1.1 impaired vision,

H3.1.2 impaired hearing, 
H3.1.3 health disorders:

H3.1.3.1 raised body temperature,

H3.1.3.4 raised blood pressure,

H3.1.4 impaired physical condition after consumption of:

H3.1.4.1 alcohol,

H3.1.4.2 intoxicants,

H3.2 Mental condition:

H3.2.1 level of intelligence,

H3.2.2 improper behavior in the environment of the road:

H3.2.2.1 standing, lying on the road,

H3.2.2.2 walking on the wrong side of the road, entering the road on red light,

H3.2.2.3 reckless entering the road in front of an oncoming vehicle,

H3.2.2.4 reckless entering the road from behind a vehicle,

H3.2.2.5 crossing a street in a forbidden place,

H3.2.2.6 moving on the road without proper caution signs,

H3.2.3 aggression toward the driver,

H4 People present in the maintenance subsystem:

H4.1 Improper actions of diagnosticians:

H4.1.1 Incorrect diagnosis,

H4.1.2 Improper result of diagnosis,

H4.2 Improper actions of mechanics:

H4.2.1 application of unsuitable materials,

H.2.2 errors of regulation,

H4.2.3 incorrect technology of repair,

H4.2.4 application of unsuitable spare part,

H4.2.5 application of a faulty element,

H4.2.6 application of a part made of unsuitable material,

H4.2.7 application of a part with hidden technological defect,

H4.2.8 application of a part with mismatched dimensions,

H4.2.9 montage errors,

H4.2.10 post repair pollution, 
Assessment of the influence of the human factor on safety ...

Ocena wplywu czynnika ludzkiego na bezpieczeństwo ...

\section{Summary}

In order to determine the most frequent undesirable actions of vehicle drivers and behaviors of pedestrians, called initiating events, probabilities of their occurrence need to be determined. Determination of these probabilities will allow to establish the most common initiating events and taking actions in order to find out their influence on occurrence of undesirable events (top event).

According to the results of carried out tests, the most common causes of occurrence of undesirable road traffic events are improper behaviors of vehicle drivers and pedestrians. In order to eliminate improper behaviors of pedestrians it is advisable to identify places where in consequence of these behaviors, undesirable road events take place most frequently. It will allow to develop guidelines for modernization of infrastructure which would limit or entirely eliminate occurrence of improper behaviors of pedestrians.

\section{References}

[1] Woropay M., Bojar P., Pająk M.: Use of analtic hierarchy process for assessment of transport system operation safety. Journal of KONBiN, No2, 3 $(14,15) 2010$

[2] Bojar P., Woropay M., Muślewski Ł.: Propozycja budowy metody oceny niepożądanych działań ludzi usytuowanych w systemie antropotechnicznym i jego otoczeniu. Logistyka nr 4/2010

[3] Woropay M., Wdzięczny A., Bojar P., Szubartowski M.: Metoda oceny wpływu skuteczności realizowanych napraw na niezawodność i bezpieczeństwo działania systemó3.1. transportu miejskiego. Wydawnictwo Naukowe Instytutu Technologii Eksploatacji. Radom 2008

[4] Oziemski.S: Człowiek w maszynie. Wydawnictwo Instytutu Technologii Eksploatacji. Radom - Warszawa 2004

[5] Wypadki drogowe w Polsce w 2011 roku. Raport Komendy Głównej Policji, Biuro Ruchu Drogowego, Zespół Profilaktyki i Analiz. Warszawa 2012

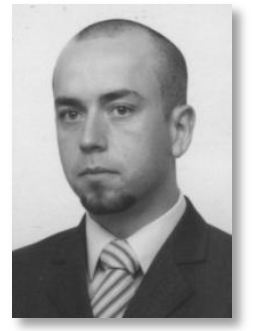

Ph.D Piotr Bojar is work in Transport Department at the Mechanical Engineering Faculty of the University of Technology and Life Sciences in Bydgoszcz. In his research he deals with analysis and assessment of operational safety of real means of road transport. Author and co-author of several scientific papers on road transport safety and reliability of technical objects. 

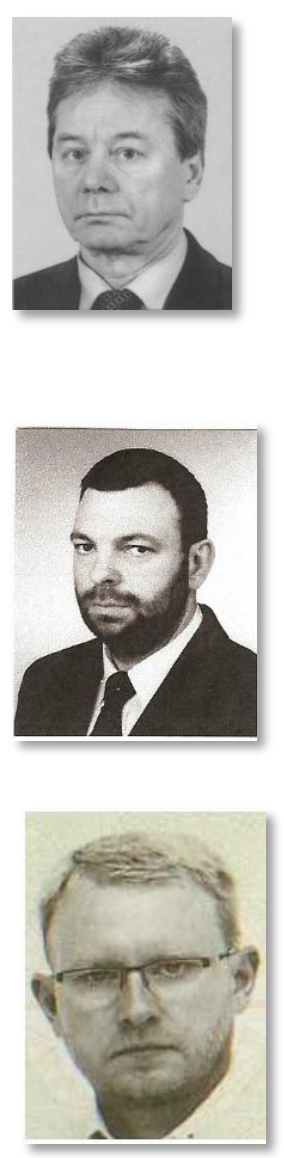

Professor Maciej Woropay is the head of the Machine Maintenance Department at the Mechanical Engineering Faculty of the University of Technology and Life Sciences in Bydgoszcz. In his research he deals with problems connected with theory of systems, theory of reliability and safety, and maintenance process control in complex biotechnical systems, especially with control of these processes in real transport systems.

Ph.D Mirosław Szubartowski works in the College of Enterprise and Technology in Włocławek, Poland. In his scientific research he concentrates on modeling of complex technological object operation systems as well as processes carried out therein. He has authored and co-authored several dozen scientific publications in the areas of reliability, availability and safety of transport system operation.

Ph.D Michał Bacior, PHD in Warsaw School of Economics. Specialist in Banking and Financial Analysis. Director in International Lime Corporation Ltd - company specialising in producing and selling different lime products; additionally employed in Engel Management Service Ltd as Financial Consultant responsible mainly for financing projects. Assistant Professor at University of Technology and Enterprise in Włocławek, specialising in Economy of Transport Processes. 


\title{
ASSESSMENT OF THE IMPACT OF HUMAN ON SAFETY OF TRANSPORTATION SYSTEMS OPERATION
}

\section{OCENA WPLYWU ODDZIALYWAŃ CZLOWIEKA NA BEZPIECZEŃSTWO DZIALANIA SYSTEMU TRANSPORTOWEGO}

\author{
Maciej Woropay ${ }^{1}$, Lukasz Muślewski², \\ Marek Ślęzak ${ }^{3}$, Mirosław Szubartowski ${ }^{4}$ \\ ${ }^{1}$ Wloclawek College of Enterprise and Technology \\ ${ }^{2}$ University of Technology and Life Sciences in Bydgoszcz \\ ${ }^{3}$ Automotive Industry Institute - Warsaw, ${ }^{4}$ Karor Sp. j., Bydgoszcz \\ e-mail:l.muslewski@wp.pl
}

\begin{abstract}
Collisions are inseparably connected with road traffic. Driving a mechanical vehicle requires not only a good knowledge of traffic rules and appropriate skills but also physical and psychical fitness. The road system consists of three basic elements such as: road, vehicle and human. From the point of view of safety of the executed transport process this is the human who plays the most important role in it. They need to have the ability of quick situation estimation and providing proper response to it involving performance of right maneuvers and adjusting them to a given situation. Studying transportation systems it should be remembered that the role of a human plays in them is of different character. They may be drivers, passengers or belong to the environment. Thus, their behavior has a large influence on the transportation system safe functioning including both public and individual transport.
\end{abstract}

Keywords: hazard, safety, transportation system, impact.

Streszczenie: Nieodtacznym elementem ruchu drogowego sq wypadki. Prowadzenie pojazdu samochodowego wymaga od operatora nie tylko wiedzy $i$ umiejętności ale także sprawności fizycznej i psychicznej. Na system drogowy sktadaja sie trzy podstawowe elementy, takie jak droga, pojazd oraz człowiek. $Z$ punktu widzenia bezpieczeństwa realizowanego procesu transportowego najistotniejsza role odgrywa właśnie czlowiek. Musi on posiadać umiejętność właściwej oceny sytuacji, wykonywania prawidłowych manewrów $i$ dostosowywania ich do aktualnej sytuacji. Analizujac systemy transportowe, należy mieć na uwadze, że człowiek, petni w nich różne funkcje. Może być zarówno kierowca środka transportu, jak też jego pasażerem lub stanowić nieodzowny elementem otoczenia systemów transportowych. Jego zachowanie w istotny sposób wptywa zarówno na bezpieczeństwo transportu indywidualnego jak i zbiorowego.

Słowa kluczowe: zagrożenie, bezpieczeństwo, system transportowy, oddziatywanie. 
Assessment of the impact of human on safety of transportation systems operation Ocena wptywu oddziaływań czlowieka na bezpieczeństwo działania...

\section{Wstęp}

Zagrożenia występujące $\mathrm{w}$ systemach transportowych, spowodowane mogą być wieloma czynnikami. Istotnym elementem takich systemów, z punktu widzenia bezpieczeństwa ich działania jest człowiek, który może pełnić różne funkcje. Może on być zarówno kierowcą środka transportu, jak też jego pasażerem. Człowiek jest również nieodzownym elementem otoczenia systemów transportowych. $\mathrm{Z}$ punktu widzenia bezpieczeństwa, to właśnie człowiek decyduje o przebiegu procesu przemieszczania się. Prawidłowe jego reagowanie, wiedza i doświadczenie decydująco wpływają zarówno na bezpieczeństwo transportu indywidualnego jak i zbiorowego.

Analizy stanu bezpieczeństwa na drogach wykazały, że przyczyny zależne od człowieka stanowią $97 \%$ wszystkich zdarzeń, natomiast wypadki i kolizje zależne od człowieka ok. $80 \%$ z nich [1]. Przyczyną aż $12 \%$ wypadków drogowych jest nietrzeźwość kierowców. Innymi przyczynami jest niekompetencja, zaniedbania oraz nieświadomie popełniane błędy. Nadmierna prędkość może być wynikiem zarówno bezmyślności czy brawury, braku doświadczenia czy umiejętności zachowania się w danej sytuacji, jak i błędnej oceny sytuacji na drodze $[7,9,10]$.

Badając zależność pomiędzy wypadkami drogowymi a wpływem kierowców na ich występowanie, konieczna jest wnikliwa analiza zdarzeń drogowych oraz ocena wpływu czynników warunkujących ich zachowanie.

\section{Charakterystyka obiektu badań}

Obiektem badań jest złożony, rzeczywisty system eksploatacji transportu miejskiego, który jest celowym wytworem człowieka, o określonym zbiorze zastosowań. W systemie tym, realizowane są zadania przewozowe eksploatowanymi środkami transportowymi, na terenie dużej aglomeracji miejskiej. Miasto wraz z obszarem podmiejskim obejmuje obszar o powierzchni $1550 \mathrm{~km}^{2}$, na terytorium którego zamieszkuje około 1,5 miliona osób. W bezpośrednim otoczeniu miasta znajdują się gminy o charakterze miejskim i miejsko - wiejskim, których charakter i specyfika funkcjonowania oraz wpływ na rozwój miasta, warunkuje włączenie ich do miejskiego systemu komunikacyjnego.

Podstawowymi środkami transportu w badanej aglomeracji miejskiej są:

- miejska komunikacja zbiorowa (ponad 41\% udziału),

- samochody osobowe (ponad 45\% udziału),

- taksówki (ponad 10\% udziału).

\section{Ogólna analiza problematyki wypadków drogowych}

Przedmiotem badań w niniejszym opracowaniu stanowią wypadki drogowe, przyczyny ich powstawania (ze szczególnym uwzględnieniem czynnika ludzkiego), liczność, częstotliwość i miejsce występowania oraz skutki i ich następstwa. Szkodą, jaka powstała w wyniku wypadku, może być utrata lub uszczerbek zdrowia a także zniszczenie obiektu lub degradacja środowiska naturalnego [5]. 
Maciej Woropay, Łukasz Muślewski, Marek Ślęzak, Mirosław Szubartowski

Straty osobowe, to straty związane z uszkodzeniem ciała uczestników wypadków drogowych. Do najczęstszych strat osobowych, które powstają $\mathrm{w}$ trakcie wypadków, zaliczane są:

- uszkodzenia głowy,

- uszkodzenia kręgosłupa,

- uszkodzenia kończyn,

- obrażenia klatki piersiowej,

- obrażenia wewnętrzne.

Obrażenia, jakie powstają w wyniku wypadków drogowych, oceniane są według różnych kryteriów. W Polsce klasyfikacja zdarzeń drogowych oraz strat w ruchu drogowym, zawarta jest w Zarządzeniu Komendanta Głównego Policji nr 635 z dnia 30.11.2006 roku, dotyczącym zbierania danych statystycznych o zdarzeniach drogowych [2]. Niniejsze zarządzenie definiuje:

- wypadek drogowy jako zdarzenie drogowe, w których są ofiary w ludziach, w tym także u sprawcy tego zdarzenia,

- kolizję drogową jako zdarzenie drogowe, które pociągnęło za sobą wyłącznie straty materialne,

- śmiertelną ofiarę wypadku jako osobę, która zmarła na miejscu wypadku lub w ciągu 30 dni od dnia wypadku na skutek doznanych obrażeń ciała,

- osobę ciężko ranną jako osobę, która doznała ciężkiego kalectwa, ciężkiej choroby nieuleczalnej lub długotrwałej choroby realnie zagrażającej życiu, trwałej choroby psychicznej, całkowitej lub znacznej niezdolności do pracy w zawodzie lub trwałego, istotnego zeszpecenia lub zniekształcenia ciała oraz urazów w postaci np. złamań, uszkodzeń organów wewnętrznych, poważnych ran ciętych i szarpanych,

- osobę lekko ranną jako osobę, której czynności narządu ruchu lub uszczerbek na zdrowiu nie trwa dłużej niż 7 dni.

- stratami materialnymi są zniszczenia pojazdów, drogi czy też budynków a także dóbr materialnych, które były przewożone a ich uszkodzenia powstały w trakcie wypadku drogowego.

Do uszkodzeń i strat powstałych w wyniku zdarzeń drogowych zalicza się $[3,4,6]$ :

- uszkodzenia pojazdów: kasację pojazdu, uszkodzenia elementów przednich pojazdu, uszkodzenia elementów tylnych pojazdu, uszkodzenia elementów bocznych pojazdu,

- uszkodzenie otoczenia: uszkodzenie obiektów drogowych, uszkodzenia obiektów poza drogą, uszkodzenia barier, uszkodzenia nawierzchni,

- straty ekonomiczne - finansowe, które ponoszą uczestnicy wypadków w wyniku ich zaistnienia takie jak: opłaty ubezpieczeniowe, koszty napraw, utratę dochodu, koszty leczenia, koszty akcji ratowniczych,

- straty środowiskowe: zatrucie ludzi gazami lub substancjami toksycznymi, zatrucie roślin i zwierząt, zatrucie wód, zatrucie atmosfery. 
Assessment of the impact of human on safety of transportation systems operation Ocena wptywu oddziatywań czlowieka na bezpieczeństwo działania...

\section{Budowa modelu ocenowego}

W dalszej części opracowania, analizie poddano wypadki drogowe, zaistniałe na wybranym obszarze badań, w określonym przedziale czasowym, które powstały w wyniku niewłaściwego zachowania człowieka.

Do oceny wpływu oddziaływań czynników ludzkich, na zagrożenia w systemie transportowym wybrano wskaźniki, na podstawie których określono ich wpływ na zdarzenia, zaistniałe w rozpatrywanym systemie transportowym. Oceny dokonano z zastosowaniem wyróżnionych wskaźników $\left(\mathrm{W}_{1} \div \mathrm{W}_{7}\right)$, opisanych zależnościami $1 \div 7$ :

- Liczba wypadków drogowych, spowodowanych przez kierujących pojazdami, przypadająca na 100 wypadków drogowych:

gdzie:

$$
\mathrm{W}_{1}=\frac{L_{W K}{ }^{\circ} 100}{L_{W}},
$$

$\mathrm{L}_{\mathrm{W}}$ - liczba wszystkich zaistniałych zdarzeń drogowych w analizowanym przedziale czasu,

$\mathrm{L}_{\mathrm{WK}}$ - liczba wypadków drogowych spowodowana przez kierujących pojazdami w analizowanym przedziale czasu.

- Liczba osób zabitych, przypadająca na 100 wypadków drogowych, spowodowanych przez kierujących pojazdami:

$$
\mathrm{W}_{2}=\frac{L_{Z K}{ }^{\circ} 100}{L_{W K}},
$$

gdzie:

$\mathrm{L}_{\mathrm{ZK}}$ - liczba osób zabitych w wypadkach spowodowanych przez kierujących pojazdami,

$\mathrm{L}_{\mathrm{WK}}$ - liczba wypadków drogowych spowodowana przez kierujących pojazdami w analizowanym przedziale czasu.

- Liczba wypadków na prostych odcinkach drogi, z powodu nadmiernej prędkości:

$$
\mathrm{W}_{3}=\frac{L_{W p}{ }^{\circ} N P}{100}
$$

gdzie:

$\mathrm{L}_{\mathrm{Wp}}$ - liczba wszystkich zaistniałych zdarzeń drogowych, w analizowanym przedziale czasu,

NP - liczba wypadków drogowych, zaistniałych z powodu nadmiernej prędkości. 
- Liczba wypadków na prostych odcinkach drogi spowodowana nieudzieleniem pierwszeństwa przejazdu:

gdzie:

$$
\mathrm{W}_{4}=\frac{L_{W n}{ }^{\circ} N P i}{100}
$$

$\mathrm{L}_{\mathrm{Wn}}$ - liczba wszystkich zaistniałych zdarzeń drogowych w analizowanym przedziale czasu,

NPi - liczba wypadków drogowych spowodowana nieudzieleniem pierwszeństwa przejazdu.

- Liczba wypadków na skrzyżowaniach dróg spowodowana nieudzieleniem pierwszeństwa przejazdu:

gdzie:

$$
\mathrm{W}_{5}=\frac{L_{W n p}{ }^{\circ} N P}{100},
$$

$\mathrm{L}_{\mathrm{Wnp}^{-}}$liczba zaistniałych zdarzeń drogowych na skrzyżowaniach dróg, $\mathrm{w}$ analizowanym przedziale czasu,

NP - liczba wypadków drogowych spowodowana nieudzieleniem pierwszeństwa przejazdu.

- Liczba wypadków na skrzyżowaniach dróg spowodowana niewłaściwym zachowaniem kierowcy wobec pieszego:

gdzie:

$$
\mathrm{W}_{6}=\frac{L_{W Z}{ }^{\circ} Z w p}{100},
$$

$\mathrm{L}_{\mathrm{Wz}}$ - liczba zaistniałych zdarzeń drogowych na skrzyżowaniach dróg, w analizowanym przedziale czasu,

Zwp- liczba wypadków drogowych spowodowana niewłaściwym zachowaniem kierowcy wobec pieszego.

- Liczba wypadków spowodowanych z winy pieszego:

gdzie:

$$
\mathrm{W}_{7}=\frac{L_{w}{ }^{\circ} W p}{100},
$$

$\mathrm{L}_{\mathrm{W}}$ - liczba wszystkich zaistniałych zdarzeń drogowych $\mathrm{w}$ analizowanym przedziale czasu,

$\mathrm{W}_{\mathrm{P}}$ - liczba wypadków drogowych $\mathrm{z}$ winy pieszego.

W związku z powyższym, ocenę wpływu oddziaływania czynników ludzkich, na bezpieczeństwo działania badanego systemu transportowego, dokonano na podstawie wartości wskaźników stanowiących składowe wyróżnione w zależności 8 :

$$
\mathrm{B}_{\mathrm{s}}=\left\langle\mathrm{W}_{1}, \mathrm{~W}_{2}, \mathrm{~W}_{3}, \mathrm{~W}_{4}, \mathrm{~W}_{5}, \mathrm{~W}_{6}, \mathrm{~W}_{7}\right\rangle
$$


Assessment of the impact of human on safety of transportation systems operation Ocena wptywu oddziaływań czlowieka na bezpieczeństwo działania...

\section{Analiza wyników badań}

Badania zrealizowano w 2011r. i dotyczyły one zaistniałych zdarzeń drogowych, w wybranej aglomeracji miejskiej. Wyniki badań pozyskano na podstawie danych statystycznych: Zarządu Ruchu Drogowego, Biura Służby Prewencyjnej Komendy Głównej Policji, baz danych Systemu Wspomagania Zarządzania Drogami i Ruchem Drogowym, programu poprawy bezpieczeństwa ruchu drogowego GAMBIT a także materiałów NIK, Ministerstwa Transportu, Budownictwa i Gospodarki Morskiej oraz przedsiębiorstwa komunikacji miejskiej.

W modelu ocenowym opisanym zależnością 8 , wyróżniono siedem wskaźników, których wartości wyznaczono na podstawie otrzymanych wyników badań, co opisano zależnościami $9 \div 15$.

- Liczba wypadków drogowych, spowodowanych przez kierujących pojazdami, przypadająca na 100 wypadków drogowych:

$$
\mathrm{W}_{1}=\frac{634 \cdot 100}{789}=80,3
$$

$\mathrm{Na}$ podstawie analizy wyników badań stwierdzono, że najczęstszą przyczyną wypadków, w analizowanym okresie czasu, była wina kierujących pojazdami. Byli oni sprawcami ponad 80/100 wypadków.

- Liczba osób zabitych, przypadająca na 100 wypadków drogowych, spowodowanych przez kierujących pojazdami:

$$
\mathrm{W}_{2}=\frac{54 \cdot 100}{789}=6,84
$$

W badanym okresie czasu w wypadkach drogowych śmierć poniosło 59 osób, z czego 54 osoby zginęły w wypadkach drogowych, które spowodowane były przez operatorów pojazdów.

Ogółem, w Polsce liczba osób zabitych, przypadająca na 100 wypadków drogowych wynosi 10,1. Dla porównania można podać, że wskaźnik zabitych na 100 wypadków w krajach Unii Europejskiej wynosi: Bułgaria $(11,7)$, Rumunia $(9,1)$, Litwa $(8,5)$, Grecja $(8,4)$, Dania $(7,3)$, Łotwa $(6,8)$, Francja $(5,9)$, Estonia $(5,8)$, Holandia $(5,0)$, Słowacja $(4,6)$, Finlandia $(4,5)$, Węgry $(4,5)$, Luksemburg $(4,1)$, Czechy $(4,1)$, Irlandia $(3,2)$, Hiszpania $(2,9)$, Malta $(2,6)$, Portugalia $(2,4)$, Belgia $(2,1)$, Włochy $(1,9)$, Słowenia $(1,8)$, Szwecja $(1,6)$, Austria $(1,6)$, Niemcy $(1,3)$, Wielka Brytania $(1,2)$.

Znając ogólną liczbę wypadków, do których doszło na prostych odcinkach drogi (522) oraz przyczyny takich wypadków, wyliczyć można:

- ilość wypadków na prostych odcinkach drogi z powodu nadmiernej prędkości:

$$
\mathrm{W}_{3}=\frac{522 \cdot 37}{100}=193,14
$$

- ilość wypadków na prostych odcinkach drogi z powodu nieudzielenia pierwszeństwa:

$$
\mathrm{W}_{4}=\frac{522 \cdot 17,5}{100}=91,35
$$


Na skrzyżowaniach na terenie obiektu, który jest przedmiotem analizy, wydarzyło się 114 wypadków. Można więc obliczyć, że:

- ilość wypadków na skrzyżowaniach z powodu nieudzielenia pierwszeństwa wyniosła:

$$
\mathrm{W}_{5}=\frac{114 \cdot 61,5}{100}=70,11
$$

- ilość wypadków na skrzyżowaniach z powodu nieprawidłowego zachowania wobec pieszego to:

$$
\mathrm{W}_{6}=\frac{114 \cdot 20,0}{100}=22.80
$$

Największa ilość wypadków ma miejsce na drogach jedno jezdnych dwukierunkowych. Na drogach takich zdarza się 82,9 \% wszystkich wypadków a ginie w nich 89,3 \% ogólnej liczby osób, które poniosły śmierć w wyniku wypadków drogowych.

Do największej ilości wypadków drogowych dochodzi w trakcie realizacji procesów transportowych - podczas jazdy pojazdów. Ten rodzaj wypadków drogowych w roku 2011 stanowił 49,2 \% ogólnej liczby wypadków. Drugą co do liczby ilości wypadków jest najechanie na pieszego, świadczy to o nieuwadze i brawurze kierowców ale także o słabej widoczności osoby pieszej, w szczególności w porach nocnych.

Podział rodzajowy wypadków w 2011 roku w ujęciu procentowym, w stosunku do ogólnej liczby wypadków przedstawia się następująco:

- zderzenie się pojazdów w ruchu: boczne $(27,9 \%)$, czołowe $(10,6 \%)$, tylne $(10,7 \%)$,

- najechanie: na pieszego $(27,3)$, na drzewo $(6,1 \%)$, na słup $(1,8 \%)$, na stojący pojazd $(1,1 \%)$, na barierę ochronną $(0,9 \%)$, na zwierzę $(0,4 \%)$, na dziurę $(0,2 \%)$,

- wywrócenie się pojazdu $(7,5 \%)$,

- wypadek z pasażerem $(1,7 \%)$,

- inne $(3,9 \%)$.

Wśród najczęstszych przyczyn wypadków, które spowodowane zostały w wyniku oddziaływania czynnika ludzkiego wyróżniono:

- winę kierującego - 80,3\%,

- winę pieszego - $10,9 \%$,

- winę pasażera $-0,3 \%$,

- współwinę - 1,5\%,

- inne - 7,0\% ogólnej liczby wypadków.

Analizując powyższe dane jednoznacznie wynika, że kierowcy pojazdów są głównymi sprawcami zdarzeń drogowych, natomiast $\mathrm{w}$ analizowanym zbiorze, jako istotny czynnik, stanowiący ok. 11\% przyczyn wypadków, stanowią piesi. Znając ilość wypadków, jaka wydarzyła się na terenie danego obszaru badań oraz sprawców wypadków, obliczono wartość wskaźnika $\mathrm{W}_{7}$.

$$
\mathrm{W}_{7}=\frac{789 \cdot 10,9}{100}=86
$$


Assessment of the impact of human on safety of transportation systems operation Ocena wplywu oddziaływań czlowieka na bezpieczeństwo działania...

Na podstawie powyższej zależności wyznaczono, że z winy pieszych wydarzyło się 86 wypadków. Przyczyną tych wypadków, w stosunku do ogólnej ich liczby było:

- wejście na jezdnię bezpośrednio przed jadącym pojazdem - 57\%,

- przekraczanie jezdni w miejscu niedozwolonym - 11,4\%,

- wejście na jezdnię zza pojazdu, przeszkody $-11 \%$,

- wejście na jezdnię przy czerwonym świetle $-9 \%$.

Dodatkowo analizując otrzymane wyniki badań, dokonano podziału zaistniałych wypadków w zależności od miejsca ich wystąpienia oraz według skutków ich następstw, co przedstawiono na rysunku 1.

Głównym miejscem powstawania wypadków jest jezdnia. Spowodowane jest to nie tylko nieuwagą kierowców, ale także brakiem przygotowania pieszych oraz kierowców jednośladów do uczestnictwa w ruchu drogowym zwłaszcza w czasie zmroku.

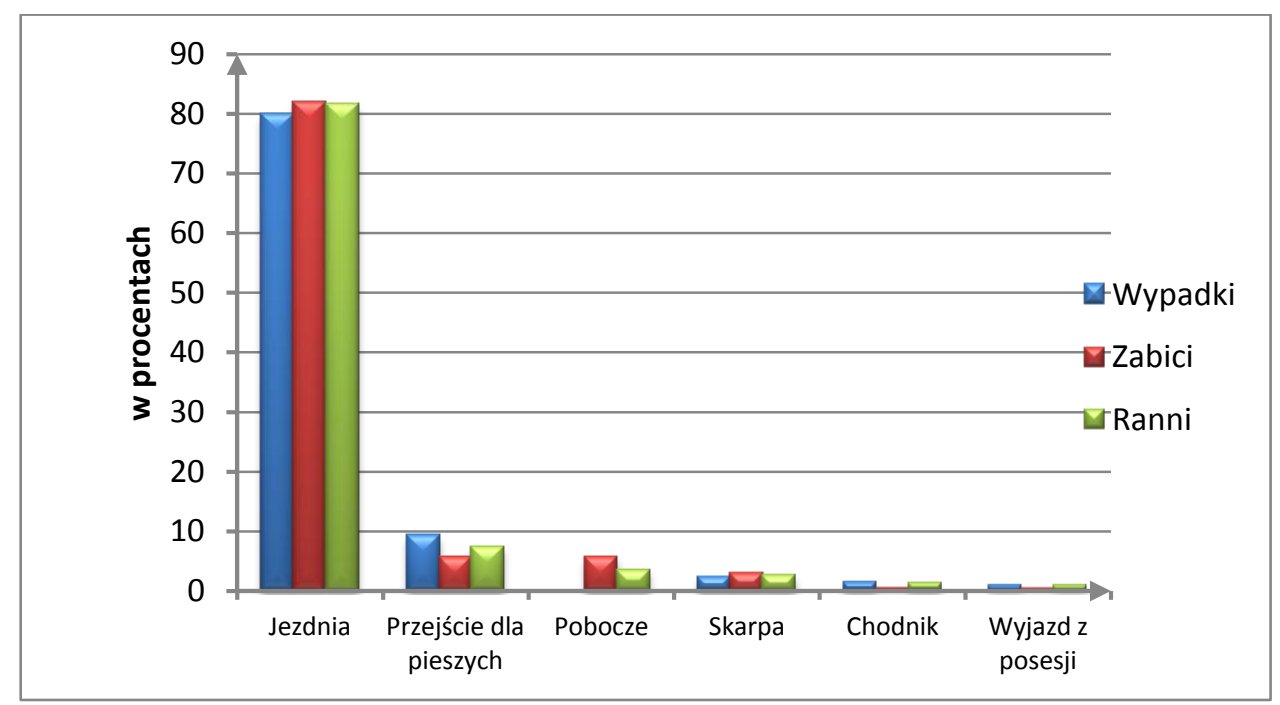

Rys. 1. Wypadki drogowe i ich skutki wedlug miejsc zajścia zdarzeń

\section{Podsumowanie}

Analizując wyniki zrealizowanych badań stwierdzono, iż najistotniejszym elementem, wpływającym na bezpieczeństwo realizowanych procesów transportowych, jest czynnik ludzki. Na terenie badanego obszaru, w roku 2011 zdarzyło się 789 wypadków drogowych, w których śmierć poniosło 59 osób a 967 zostało rannych. Najczęstszą przyczyną zaistniałych zdarzeń drogowych była wina kierujących pojazdami. Byli oni sprawcami ponad $80 \%$ wszystkich wypadków. 
Maciej Woropay, Łukasz Muślewski, Marek Ślęzak, Mirosław Szubartowski

Na podstawie szczegółowej analizy wyników zrealizowanych badań ustalono, że sprawcami największej liczby wypadków, są kierujący pojazdami w przedziale wiekowym od 18 do 24 roku życia. Łącznie w roku 2011 spowodowali oni $34 \%$ wszystkich wypadków drogowych. Drugą grupą kierujących są osoby w przedziale wiekowym od 25 do 39 roku życia, którzy byli sprawcami 22,6 \% ogółu wypadków. Największą liczbę wypadków zanotowano w miesiącach od maja do października i w grudniu. Badając podział wypadków w poszczególnych dniach tygodnia stwierdzono, że aż 16,6 \% wypadków zdarza się w piątki, natomiast najwięcej osób, bo aż 16,3 \% ginie w wypadkach, które zdarzają się w soboty. Średnio w co dziewiątym wypadku, do którego dochodzi w soboty ginie człowiek. Największe nasilenie wypadków występuje w godzinach pomiedzy 14.00 a 19.00. Związane jest to ze zwiększonym nasileniem ruchu, w szczególności z powrotami z pracy. Najmniejsza ilość wypadków zdarza się w godzinach nocnych pomiedzy godziną 24.00 a 5.00 rano. Wpływ na ilość wypadków mają także warunki atmosferyczne oraz oświetlenie dróg. Najwięcej wypadków odnotowano w ciągu dnia, co związane jest ze zwiększonym natężeniem ruchu. Zauważyć jednak należy, że na drogach nieoświetlonych w porze nocnej notowany jest największy wskaźnik osób zabitych Do największej liczby wypadków dochodzi na terenach zabudowanych. Poza obszarem zabudowanym wypadków drogowych jest znacznie mniej, jednak ginie w nich więcej osób. Największa ilość wypadków ma miejsce na drogach jedno jezdniowych, dwukierunkowych. Na drogach takich zdarza się 82,9 \% wszystkich wypadków a ginie w nich 89,3 \% ogólnej liczby osób, które poniosły śmierć w wyniku wypadków drogowych.

\section{Bibliografia}

[1] Komenda Główna Policji, Najczęstsze przyczyny wypadków drogowych. czerwiec 2006.

[2] Komenda Główna Policji: Zarządzenie Komendanta Głównego Policji nr $635 / 2006$.

[3] Michalski R.: Metoda szacowania ryzyka w ruchu drogowym pojazdów. MOTROL, 2007, vol. 9, pp. 111 - 120.

[4] Muślewski Ł.: Podstawy efektywności działania systemów transportowych. ITE, 2010.

[5] Praca zbiorowa pod red. R. Krystka: Zintegrowany System Bezpieczeństwa Transportu, t.2. WKŁ, Warszawa 2009.

[6] Szczuraszek T.: Bezpieczeństwo ruchu miejskiego. WKiŁ, Warszawa 2008.

[7] Szopa T. Wprowadzenie w problematykę bezpieczeństwa. Bezpieczeństwo człowieka we współczesnym świecie. IPWC, Warszawa 1998. 
Assessment of the impact of human on safety of transportation systems operation Ocena wptywu oddziatywań czlowieka na bezpieczeństwo działania...

[8] Woropay M., Bojar P., Muślewski Ł. Ocena istotności podsystemów środka transportu. TransComp, Zakopane - Radom 2010.

[9] Woropay M., Muślewski Ł.: Jakość w ujęciu systemowym. ITE, Radom 2005.

[10]Zielińska A.: Rok 2005 na polskich drogach. Analiza danych o wypadkach drogowych, Kwartalnik BRD nr 1/2006.

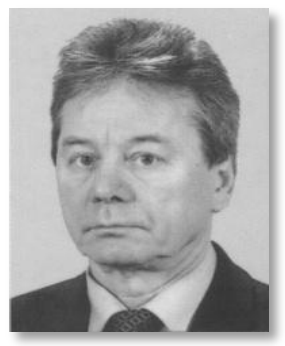

Professor Maciej Woropay is the head of the Machine Maintenance Department at the Mechanical Engineering Faculty of the University of Technology and Life Sciences in Bydgoszcz. In his research he deals with problems connected with theory of systems, theory of reliability and safety, and maintenance process control in complex biotechnical systems, especially with control of these processes in real transport systems.

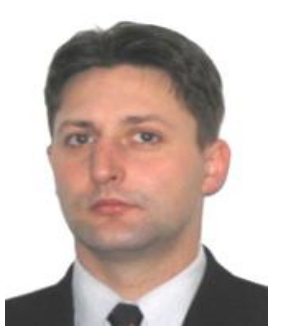

D. Sc. Eng. Lukasz Muślewski occupies the post of associate professor at the Faculty of Mechanical Engineering of UT-P in Bydgoszcz. He is involved in research into the quality of operation of complex operation and maintenance of transportation systems. The scope of the research covers reliability, safety, efficiency, and environment friendliness of systems, whose functioning is affected by their operators, technical object operated by them and the impact of environmental factors.

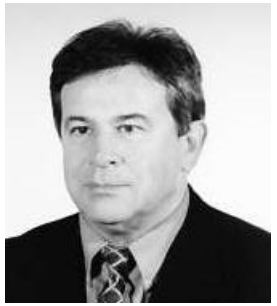

mgr inj. Marek Ślęzak - pracownik naukowy Przemysłowego Instytutu Motoryzacji (PIMOT) oraz Instytutu Lotnictwa w Warszawie. Mechanik - budowa maszyn, specjalność napędy, systemy $i$ środki transportu. Autor $i$ współautor 45 publikacji w języku polskim i angielskim.

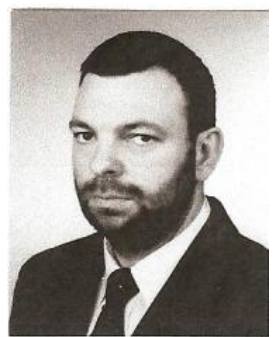

Ph.D Mirostaw Szubartowski works in the College of Enterprise and Technology in Wtoctawek, Poland. In his scientific research he concentrates on modeling of complex technological object operation systems as well as processes carried out therein. He has authored and co-authored several dozen scientific publications in the areas of reliability, availability and safety of transport system operation. 
EMERGENCY WATER SUPPLY OF RZESZOW KRYZYSOWE ZAOPATRZENIE RZESZOWA W WODE

\author{
Janusz R. Rak, Izabela Piegdoń, Karolina Homa \\ Politechnika Rzeszowska im. Ignacego Łukasiewicza \\ e-mail: rakjan@prz.edu.pl,piegi@prz.edu.pl
}

\begin{abstract}
In this study the methodology of balancing water needs in a crisis situation was presented. The example was done for city of Rzeszow. The municipal infrastructure: water supply system, sewage system, gas network, heating and energy systems was shortly characterized. The research undertaken in this study was related to Systemic Crisis Management and protection of the inhabitants of the city. The balance of emergency water supply Rzeszow in drinking water for the 29 neighborhoods of the city was shown.
\end{abstract}

Keywords: collective water supply system, consumer risk, failure

Streszczenie: $W$ pracy przedstawiono metodyke bilansowania zapotrzebowania na wode w sytuacji kryzysowej, na przykładzie miasta Rzeszowa. Scharakteryzowano infrastrukture komunalna miasta: sieć wodociagowa, sieć kanalizacyjna, sieć gazowa, ciepłownicza oraz energetyczna. Problem badawczy podejmowany w pracy odniesiono do Systemowego Zarzadzania Kryzysowego $i$ ochrony mieszkańców miasta. Pokazano sposób bilansowania awaryjnego zaopatrzenia Rzeszowa w wodę do spożycia dla 29 osiedli Rzeszowa.

Stowa kluczowe: awaryjność sieci wodociagowych, zarzadzanie kryzysowe 


\section{Wstęp}

Rzeszów jest stolica województwa podkarpackiego. To największy ośrodek przemysłowy, handlowo-usługowy, akademicki i kulturalny w Polsce PołudniowoWschodniej. Jego powierzchnia wynosi $116,32 \mathrm{~km} 2$, z czego tereny rolne zajmują $73,52 \mathrm{~km} 2$, tereny zurbanizowane - 36,92 km2, tereny leśne - 4,59 km2 oraz nieużytki $0,22 \mathrm{~km} 2$. Aglomerację, podzielona na 29 osiedli, zamieszkuje obecnie, zgodnie z wykazem Wydziału Spraw Obywatelskich Urzędu Miasta Rzeszowa, 180723 (dane z 15.03.2012 r.). Na rys. 1 pokazano plan miasta w ujęciu osiedlowym.

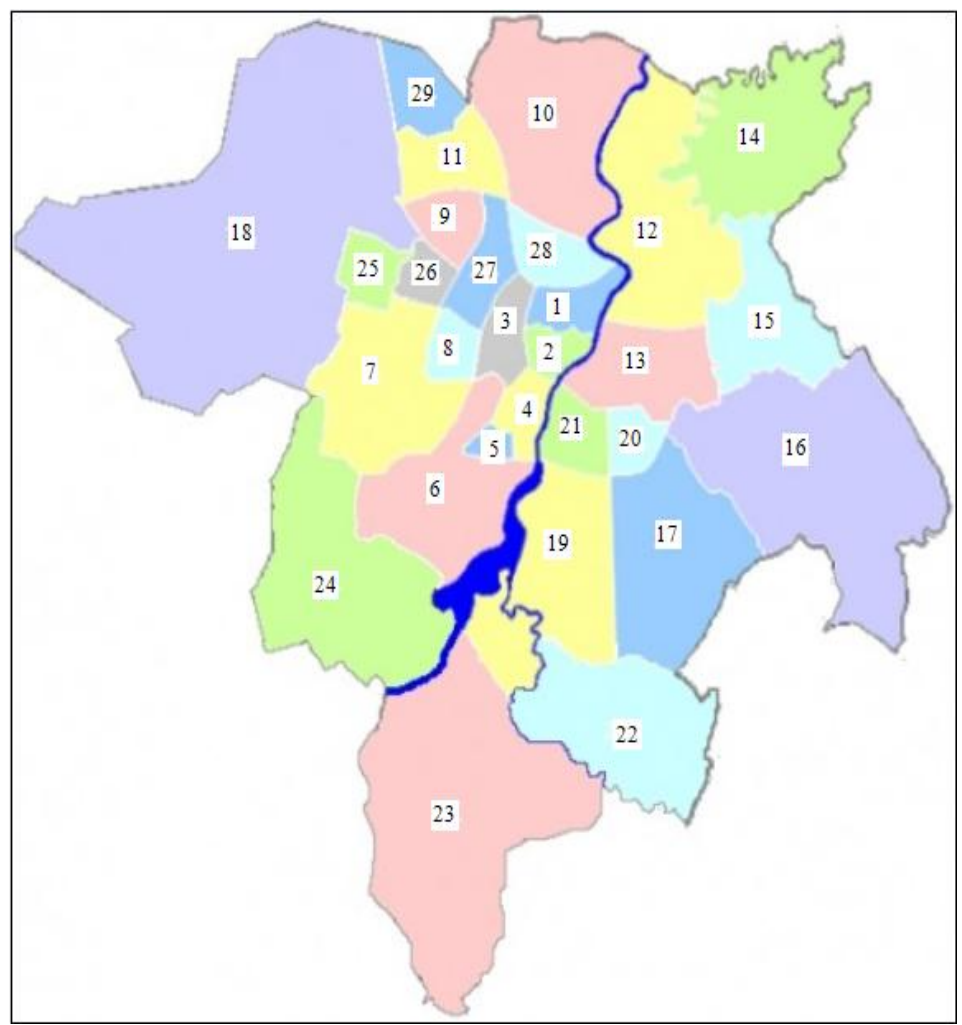

1 Śródmieście Pn.

2 Sródmieście Pd.

3 Pułaskiego

4 Gen. Roweckiego

5 Piastów

6 Dąbrowskiego

7 Staroniwa

8 Kmity

9 Gen. Andersa

10 Staromieście

11 Baranówka

12 Pobitno

13 Mieszka I

14 Załęże

15 Wilkowyja

16 Słocina

17 Zalesie

18 Przybyszówka

19 Drabinianka

20 Paderewskiego

21 Nowe Miasto

22 Biała

23 Budziwoj

24 Zwięczyca

25 Kotuli

26 Krakowska Pd.

27 Króla Augusta

281000 - lecia

29 Miłocin

Rys.1. Osiedla Rzeszowa i granice miasta

Przez Rzeszów przepływa rzeka Wisłok, która jest głównym źródłem zaopatrzenia mieszkańców miasta w wodę do spożycia. Średni niski przepływ w rzece mierzony SNQ na wysokości stopnia wodnego w Rzeszowie, wynosi 2,6 $\mathrm{m}^{3} / \mathrm{s}$ [1]. Ujmowana przy pomocy ujęcia powierzchniowo-brzegowego woda jest uzdatniana w dwóch zakładach uzdatniania; ZUzW Zwięczyca I, w której produkowane jest 36500 $\mathrm{m}^{3} / \mathrm{d}$ wody oraz ZUzW Zwięczyca II - dobowa produkcja to $47500 \mathrm{~m}^{3} /$ d. Łączna 
zdolność produkcyjna zakładów wynosi $84000 \mathrm{~m}^{3} / \mathrm{d}$. Średniodobowe zapotrzebowanie wody do spożycia wynosi $45000 \mathrm{~m}^{3} / \mathrm{d}$. Zatem nadmiarowa moc produkcyjna ZUzW Zwięczyca I i Zwięczyca II to prawie $100 \%$ Qśrd [2]. Dodatkowe ujęcia wody podziemnej są przy ul. Mazowieckiej w Rzeszowie (wydajność $240 \mathrm{~m}^{3} / \mathrm{d}$ ) i lokalne na Osiedlu Słocina (wydajność $465 \mathrm{~m}^{3} / \mathrm{d}$ ).

Celem pracy jest pokazanie metodyki bilansowania wody do spożycia w sytuacji kryzysowej na przykładzie miasta Rzeszowa.

\section{Charakterystyka infrastruktury komunalnej}

W tabeli 1 przedstawiono długości poszczególnych sieci w latach 1990 oraz 2010, w tabeli 2 zaś liczbę użytkowników odpowiednio w roku 1990 i 2010.

Tabela 1. Dlugość poszczególnych sieci w Rzeszowie

\begin{tabular}{|c|c|c|}
\hline Sieć & Dlugość w 1990 r. & Długość w 2010 r. \\
\hline Wodociągowa & $581,5 \mathrm{~km}$ & $864,1 \mathrm{~km}$ \\
\hline Kanalizacyjna & $345,0 \mathrm{~km}$ & $466,1 \mathrm{~km}$ \\
\hline Gazowa & $682,7 \mathrm{~km}$ & $882,4 \mathrm{~km}$ \\
\hline Energetyczna & $1479 \mathrm{~km}$ & $2067 \mathrm{~km}$ \\
\hline Ciepłownicza & $168 \mathrm{~km}$ & 227,6 \\
\hline
\end{tabular}

Tabela 2. Liczba użytkowników sieci w Rzeszowie

\begin{tabular}{|c|c|c|}
\hline Sieć & $\begin{array}{c}\text { Liczba użytkowników } \\
\text { na koniec 1990 r. }\end{array}$ & $\begin{array}{c}\text { Liczba użytkowników } \\
\text { na koniec 2010 r. }\end{array}$ \\
\hline Wodociągowa & $\begin{array}{c}15569 \text { odbiorców } \\
(152914 \text { mieszkańców })\end{array}$ & $\begin{array}{c}19821 \text { odbiorców } \\
(170400 \text { mieszkańców })\end{array}$ \\
\hline Kanalizacyjna & $\begin{array}{c}15269 \text { odbiorców } \\
(146135 \text { mieszkańców })\end{array}$ & $\begin{array}{c}19061 \text { odbiorców } \\
(164250 \text { mieszkańców })\end{array}$ \\
\hline Gazowa & 42574 odbiorców & 60828 odbiorców \\
\hline Energetyczna & 67591 odbiorców & 80132 odbiorców \\
\hline Ciepłownicza & 875 odbiorców & 920 odbiorców \\
\hline
\end{tabular}

\section{Realizacja zarządzania kryzysowego w Rzeszowie}

W przypadku wystąpienia sytuacji kryzysowej związanej z brakiem dostawy wody w Rzeszowie opracowany został przez MPWiK „Plan awaryjnego zaopatrzenia w wodę ludności miasta Rzeszowa". Aktualny poziom kadrowo - zawodowego przygotowania i technicznego wyposażenia MPWiK pozwalają na samodzielne realizowanie działań zapobiegawczych i usuwanie wszelkich awarii zakłócających ciągłą dostawę wody dla miasta [3]. W zależności od potrzeb podejmowane są współdziałanie $\mathrm{z}$ odpowiednimi instytucjami administracyjnymi Rzeszowa: Wydziałem Zarządzania Kryzysowego i Ochrony Ludności UM Rzeszów, 
Wydziałem Gospodarki Komunalnej i Inwestycji UM Rzeszów, Wydziałem Ochrony Środowiska i Rolnictwa UM Rzeszów, Miejskim Przedsiębiorstwem Gospodarki Komunalnej, Powiatową Stacją Sanitarno - Epidemiologiczną, Służbami porządkowymi miasta Rzeszowa - policją i strażą miejską. Obieg informacji - meldunki dotyczące rozwoju sytuacji, podejmowanych decyzji i ocena skuteczności stosowanych środków przekazywane są do Zespołu Reagowania Kryzysowego Miasta Rzeszowa i Centrum Zarządzania Kryzysowego Miasta Rzeszowa. Powiadomienie ludności o ograniczeniach w dostawach wody odbywa się za pośrednictwem lokalnych rozgłośni radiowych i telewizyjnych oraz prasy, obwieszczeń i radiowozów z nagłośnieniem. Harmonogram czynności podczas awaryjnego zaopatrzenia miasta Rzeszowa $w$ wodę, zawarty w Planie, przedstawiono w tabeli 3 .

Tabela 3. Harmonogram czynności podczas awaryjnego zaopatrzenia Rzeszowa w wode

\begin{tabular}{|c|c|c|c|}
\hline Lp. & Nazwa czynności & Siły i środki & $\begin{array}{c}\text { Czas } \\
\text { realizacji }\end{array}$ \\
\hline 1. & $\begin{array}{l}\text { Powiadomienie o } \\
\text { kryzysowej Szefa OC Miasta, } \\
\text { Wydziału Zarządzania Kryzysowego } \\
\text { i Ochrony Ludności oraz Stużbę } \\
\text { Informacyjną Wojewody }\end{array}$ & Środki łączności & $\begin{array}{l}\text { Natychmiast } \\
+1 \text { godz. }\end{array}$ \\
\hline 2. & $\begin{array}{l}\text { Powiadomienie o awarii ludności } \\
\text { miasta }\end{array}$ & $\begin{array}{l}\text { Radio, } \mathrm{TV}, \\
\text { radiowozy }\end{array}$ & $+2 \operatorname{godz}$ \\
\hline 3. & $\begin{array}{l}\text { Dokonanie stosownych przełączeń } \\
\text { sieci wodociągowej }\end{array}$ & $\begin{array}{c}\text { Pogotowie wodno - } \\
\text { kanalizacyjne, } \\
\text { dodatkowe siły } \\
\text { MPWiK } \\
\end{array}$ & + 6 godz. \\
\hline 4. & $\begin{array}{l}\text { Ściągniecie z sąsiednich gmin, } \\
\text { powiatów i miast cystern do } \\
\text { przewozu wody pitnej }\end{array}$ & Środki łączności & +8 godz. \\
\hline 5. & $\begin{array}{l}\text { Przygotowanie zakładowych ujęć } \\
\text { wody do napełniania cystern } \\
\text { samochodowych }\end{array}$ & $\begin{array}{l}\text { Służby techniczne } \\
\text { zakładów }\end{array}$ & +10 godz. \\
\hline 6. & $\begin{array}{l}\text { Koordynacja i nadzorowanie akcji } \\
\text { awaryjnego zaopatrywania ludności } \\
\text { w wody }\end{array}$ & $\begin{array}{l}\text { Zespół kierowania } \\
\text { OC, MPWiK }\end{array}$ & $\begin{array}{l}\text { Do chwili } \\
\text { zakończenia } \\
\text { akcji }\end{array}$ \\
\hline 7. & $\begin{array}{l}\text { Komunikat końcowy dla ludności } \\
\text { o osunięciu awarii i przywróceniu } \\
\text { stanu pierwotnego }\end{array}$ & $\begin{array}{l}\text { Radio, } \mathrm{TV}, \text { prasa, } \\
\text { radiowozy }\end{array}$ & $\begin{array}{c}\text { Po } \\
\text { zakończeniu } \\
\text { akcji }\end{array}$ \\
\hline
\end{tabular}




\section{Bilans awaryjnego zaopatrzenia mieszkańców Rzeszowa w wodę}

Mieszkańcy Rzeszowa są zaopatrywani w wodę $\mathrm{z}$ wodociągu miejskiego. Średniodobowe zapotrzebowanie wody dla miasta waha się w granicach 40000 $50000 \mathrm{~m}^{3} / \mathrm{d}$. Plan awaryjnego zaopatrzenia w wodę ludności miasta Rzeszowa bierze pod uwagę 180000 mieszkańców. W Planie oparto się na wytycznych Zarządzenia Ministra Gospodarki Przestrzennej i Budownictwa $\mathrm{z}$ dnia 21.09.1995r., które podaje następujące normy:

- przy awaryjnym zaopatrzeniu przyjęto ilość wody na jedną osobę w ciągu doby $-15 \mathrm{dm}^{3} / \mathrm{M}^{*} \mathrm{~d}$;

- przy minimalnej ilości wody przyjęto ilość wody na jedna osobę w ciągu doby $-7,5 \mathrm{dm}^{3} / \mathrm{M}^{*} \mathrm{~d}$.

Dodatkowo w pracy dokonano obliczeń bilansu awaryjnego zaopatrzenia w wodę [2]:

- $2,5 \mathrm{dm}^{3} / \mathrm{M}^{*} \mathrm{~d}$ - ilość wody związana z fizjologią człowieka,

- $30 \mathrm{dm}^{3} / \mathrm{M}^{*} \mathrm{~d}$ - wymagana ilość wody w sytuacji kryzysowej,

- $50 \mathrm{dm}^{3} / \mathrm{M}^{*} \mathrm{~d}$ - zalecana ilość wody w sytuacji kryzysowej.

Bilans wykonano dla poszczególnych osiedli Rzeszowa, biorąc pod uwagę liczbę mieszkańców każdego z nich, co pokazano w tabeli 4.

Tabela 4. Bilans awaryjnego dobowego zaopatrzenia w wodę dla Rzeszowa

\begin{tabular}{|c|c|c|c|c|c|c|c|}
\hline \multirow{2}{*}{ Lp } & \multirow{2}{*}{ Osiedle } & \multirow{2}{*}{\begin{tabular}{|c|} 
Liczba \\
zameldowanych \\
na stałe \\
i czasowo \\
(na dzień \\
$\mathbf{2 . 0 1 . 2 0 1 2 )}$
\end{tabular}} & \multicolumn{5}{|c|}{$\begin{array}{l}\text { Konieczna ilość wody }\left[\mathrm{m}^{3} / \mathrm{d}\right] \text { przy } \\
\text { jednostkowym zapotrzebowaniu }\end{array}$} \\
\hline & & & $\begin{array}{c}2,5 \\
\mathrm{dm}^{3} / \mathrm{M}^{*} \mathrm{~d}\end{array}$ & $\begin{array}{c}\mathbf{7 , 5} \\
\mathrm{dm}^{3} / \mathrm{M}^{*} \mathrm{c}\end{array}$ & $\begin{array}{c}15 \\
\mathrm{dm}^{3} / \mathrm{M} * \mathrm{~d}\end{array}$ & $\begin{array}{c}30 \\
\mathrm{dm}^{3} / \mathrm{M} * \mathrm{~d}\end{array}$ & $\begin{array}{c}\mathbf{5 0} \\
\mathrm{dm}^{3} / \mathrm{M} * \mathrm{~d}\end{array}$ \\
\hline 1 & $\begin{array}{l}\text { Śródmieście } \\
\text { Północ }\end{array}$ & 4727 & 11,8 & 35,5 & 70,9 & 141,8 & 236,4 \\
\hline 2 & $\begin{array}{l}\text { Śródmieście } \\
\text { Południe }\end{array}$ & 3718 & 9,3 & 27,9 & 55,8 & 111,5 & 185,9 \\
\hline 3 & Pułaskiego & 5260 & 13,2 & 39,5 & 78,9 & 157,8 & 263,0 \\
\hline 4 & $\begin{array}{l}\text { Generała } \\
\text { Roweckiego }\end{array}$ & 8367 & 20,9 & 62,8 & 125,5 & 251,0 & 418,4 \\
\hline 5 & Piastów & 4889 & 12,2 & 36,7 & 73,3 & 146,7 & 244,5 \\
\hline 6 & Dąbrowskiego & 6917 & 17,3 & 51,9 & 103,8 & 207,5 & 345,9 \\
\hline 7 & Staroniwa & 2737 & 6,8 & 20,5 & 41,1 & 82,1 & 136,9 \\
\hline
\end{tabular}


Tabela 4. c.d.

\begin{tabular}{|c|l|c|c|c|c|c|c|}
\hline 8 & Kmity & 7581 & 19,0 & 56,9 & 113,7 & 227,4 & 379,1 \\
\hline 9 & $\begin{array}{l}\text { Generała } \\
\text { Andersa }\end{array}$ & 12155 & 30,4 & 91,2 & 182,3 & 364,7 & 607,8 \\
\hline 10 & Staromieście & 3412 & 8,5 & 25,6 & 51,2 & 102,4 & 170,6 \\
\hline 11 & 1000 - lecia & 9516 & 23,8 & 71,4 & 142,7 & 285,5 & 475,8 \\
\hline 12 & Pobitno & 3987 & 10,0 & 29,9 & 59,8 & 119,6 & 199,4 \\
\hline 13 & Mieszka I & 10508 & 26,3 & 78,8 & 157,6 & 315,2 & 525,4 \\
\hline 14 & Nowe miasto & 15416 & 38,5 & 115,6 & 231,2 & 462,5 & 770,8 \\
\hline 15 & Wilkowyja & 4743 & 11,9 & 35,6 & 71,1 & 142,3 & 237,2 \\
\hline 16 & Słocina & 5444 & 13,6 & 40,8 & 81,7 & 163,3 & 272,2 \\
\hline 17 & Zalesie & 7376 & 18,4 & 55,3 & 110,6 & 221,3 & 368,8 \\
\hline 18 & Przybyszówka & 6856 & 17,1 & 51,4 & 102,8 & 205,7 & 342,8 \\
\hline 19 & Baranówka & 10980 & 27,5 & 82,4 & 164,7 & 329,4 & 549,0 \\
\hline 20 & Króla Augusta & 5597 & 14,0 & 42,0 & 84,0 & 167,9 & 279,9 \\
\hline 21 & Paderewskiego & 4364 & 10,9 & 32,7 & 65,5 & 130,9 & 218,2 \\
\hline 22 & Drabinianka & 9263 & 23,2 & 69,5 & 138,9 & 277,9 & 463,2 \\
\hline 23 & $\begin{array}{l}\text { Krakowska } \\
\text { Południe }\end{array}$ & 8214 & 20,5 & 61,6 & 123,2 & 246,4 & 410,7 \\
\hline 24 & Kotuli & 4902 & 12,3 & 36,8 & 73,5 & 147,1 & 245,1 \\
\hline 25 & Załęże & 1986 & 5,0 & 14,9 & 29,8 & 59,6 & 99,3 \\
\hline 26 & Zwięczyca & 3253 & 8,1 & 24,4 & 48,8 & 97,6 & 162,7 \\
\hline 27 & Biała & 2283 & 5,7 & 17,1 & 34,2 & 68,5 & 114,2 \\
\hline 28 & Miłocin & 733 & 1,8 & 5,5 & 11,0 & 22,0 & 36,7 \\
\hline 29 & Budziwój & 4635 & 11,6 & 34,8 & 69,5 & 139,1 & 231,8 \\
\hline & Razem: & $\mathbf{1 7 9 8 1 9}$ & $\mathbf{4 4 9 , 5}$ & $\mathbf{1 3 4 8 , 6}$ & $\mathbf{2 6 9 7 , 3}$ & $\mathbf{5 3 9 4 , 6}$ & $\mathbf{8 9 9 1 , 0}$ \\
\hline
\end{tabular}

Założono, że mieszkańcom Rzeszowa w sytuacji kryzysowej będzie dostarczana woda do spożycia w butelkach 5 litrowych. W tabeli $\mathrm{nr} 5$ przedstawiono liczbę butelek przypadającą na jednego mieszkańca w zależności od awaryjnego zaopatrzenia ludności w wodę. 
Tabela 5. Liczba butelek 5 litrowych przypadająca na 1-go mieszkańca w sytuacji kryzysowej

\begin{tabular}{|c|c|c|c|c|c|}
\hline \multirow{2}{*}{} & \multicolumn{5}{|c|}{ Konieczna ilość wody $\left[\mathbf{m}^{\mathbf{3}} / \mathbf{d}\right]$ przy jednostkowym zapotrzebowaniu } \\
\cline { 2 - 6 } & $\begin{array}{c}\mathbf{2 , 5} \\
\mathbf{d m}^{3} / \mathbf{M}^{*} \mathbf{d}\end{array}$ & $\begin{array}{c}\mathbf{7 , 5} \\
\mathbf{d m}^{3} / \mathbf{M} \mathbf{M}\end{array}$ & $\begin{array}{c}\mathbf{1 5} \\
\mathbf{d m}^{\mathbf{3}} / \mathbf{M}^{*} \mathbf{d}\end{array}$ & $\begin{array}{c}\mathbf{3 0} \\
\mathbf{d m}^{3} / \mathbf{M}^{*} \mathbf{d}\end{array}$ & $\begin{array}{c}\mathbf{5 0} \\
\mathbf{d m}^{3} / \mathbf{M} \mathbf{d}\end{array}$ \\
\hline $\begin{array}{c}\text { Liczba butelek } \\
\text { 5 litrowych }\end{array}$ & 0,5 & 1,5 & 3 & 6 & 10 \\
\hline
\end{tabular}

\section{Awaryjne zaopatrzenie mieszkańców Rzeszowa w wodę}

Łącznie celem zapewnienia pełnego zaopatrzenia mieszkańców poszczególnych osiedli rzeszowskich $\mathrm{w}$ wodę przeznaczoną do spożycia należy, zgodnie z bilansem, dostarczyć:

- Przy ilości wody związanej z fizjologią człowieka

- Przy minimalna ilości wody

- Przy niezbędna ilości wody

- Przy wymaganej ilości wody

$-449,5 \mathrm{~m}^{3} / \mathrm{d}$, $-1348,6 \mathrm{~m}^{3} / \mathrm{d}$,

- Przy ilości wody $50 \mathrm{dm}^{3} / \mathrm{M}^{*} \mathrm{~d}$ $-2697,3 \mathrm{~m}^{3} / \mathrm{d}$, $-5394,6 \mathrm{~m}^{3} / \mathrm{d}$, $-8991,0 \mathrm{~m}^{3} / \mathrm{d}$.

Woda mieszkańcom będzie dostarczana z wykorzystaniem pojazdów przystosowanych do przewożenia wody przeznaczonej do spożycia lub za pośrednictwem $5 \mathrm{dm}^{3}$ butelek. Wykorzystując beczkowozy i cysterny o średniej pojemności $8000 \mathrm{dm}^{3}$ oraz zakładając, że każdy z pojazdów wykona 8 kursów i w ciągu doby dostarczy średnio $64 \mathrm{~m}^{3}$ wody.

Wymaga to zapewnienia następującej liczby pojazdów lub butelek:

- przy ilości wody związanej z fizjologią człowieka - 5 pojazdów, 89900 butelek,

- przy minimalna ilości wody

- 14 pojazdów, 269720 butelek,

- przy niezbędna ilości wody

- przy wymaganej ilości wody - 27 pojazdów, 539460 butelek,

- przy ilości wody $50 \mathrm{dm}^{3} / \mathrm{M}^{*} \mathrm{~d}$ - 54 pojazdy, 1078920 butelek, -102 pojazdy, 1798200 butelek.

Zgodnie z założeniami Planu Awaryjnego Zaopatrzenia w Wodę Ludności Miasta Rzeszowa woda do celów sanitarnych dostarczana będzie mieszkańcom ze 187 studni publicznych (tabela 6) oraz około 1150 studni przydomowych (stan na 1.09.2011 r.) zlokalizowanych na rzeszowskich osiedlach. Zasadniczym źródłem poboru wody sanitarnej jest ujęcie WSK - PZL o wydajności $1200 \mathrm{~m}^{3} / \mathrm{d}$. 
Tabela 6. Studnie publiczne na rzeszowskich osiedlach

\begin{tabular}{|r|c|c|c|r|r|r|}
\hline \multirow{2}{*}{ Lp. } & \multirow{2}{*}{ Osiedle } & \multicolumn{2}{|c|}{ Liczba studni } & \multicolumn{3}{|c|}{ Wydajność studni } \\
\cline { 2 - 7 } & & Wiercone & Kopane & Wiercone & Kopane & Suma \\
\hline 1 & Śódmieście Północ & 5 & 7 & 29,2 & 4 & 33,2 \\
\hline 2 & Śódmieście Południe & 7 & 2 & 33,5 & 0,7 & 34,2 \\
\hline 3 & Pułaskiego & 9 & 1 & 31,4 & 0,2 & 31,6 \\
\hline 4 & Generała Roweckiego & 9 & 6 & 79,5 & 2,4 & 81,9 \\
\hline 5 & Piastów & 4 & 2 & 29,8 & 0,8 & 30,6 \\
\hline 6 & Dąbrowskiego & 8 & 8 & 45,2 & 6,6 & 51,8 \\
\hline 7 & Staroniwa & 1 & 0 & 2 & 0 & 2 \\
\hline 8 & Kmity & 10 & 3 & 69,9 & 2,5 & 72,4 \\
\hline 9 & Gen. Władysława Andersa & 6 & 1 & 23,9 & 0,2 & 24,1 \\
\hline 10 & Staromieście & 0 & 6 & 0 & 1,9 & 1,9 \\
\hline 11 & 1000 - lecia & 12 & 4 & 66 & 1 & 67 \\
\hline 12 & Pobitno & 1 & 6 & 0,2 & 3,2 & 3,4 \\
\hline 13 & Mieszka I & 12 & 2 & 46,9 & 0,4 & 47,3 \\
\hline 14 & Nowe miasto & 10 & 1 & 56,4 & 0,6 & 57 \\
\hline 15 & Wilkowyja & 0 & 0 & 0 & 0 & 0 \\
\hline 16 & Słocina & 0 & 0 & 0 & 0 & 0 \\
\hline 17 & Zalesie & 3 & 0 & 16,5 & 0 & 16,5 \\
\hline 18 & Przybyszówka & 0 & 0 & 0 & 0 & 0 \\
\hline 19 & Baranówka & 10 & 0 & 44,1 & 0 & 44,1 \\
\hline 20 & Króla Stanisława Augusta & 6 & 1 & 24,5 & 0,6 & 25,1 \\
\hline 21 & Paderewskiego & 6 & 4 & 33,2 & 1,2 & 34,4 \\
\hline 22 & Drabinianka & 3 & 2 & 17,2 & 0,5 & 17,7 \\
\hline 23 & Krakowska Południe & 6 & 0 & 14,7 & 0 & 14,7 \\
\hline 24 & Kotuli & 2 & 0 & 2,7 & 0 & 2,7 \\
\hline 25 & Załęże & 0 & 0 & 0 & 0 & 0 \\
\hline 26 & Zwięczyca & 0 & 0 & 0 & 0 & 0 \\
\hline 27 & Biała & 1 & 0 & 10,5 & 0 & 10,5 \\
\hline 28 & Miłocin & 0 & 0 & 0 & 0 & 0 \\
\hline 29 & Budziwój & 0 & 0 & 0 & 0 & 0 \\
\hline & & $\mathbf{1 3 1}$ & $\mathbf{5 6}$ & $\mathbf{6 7 7 , 3}$ & $\mathbf{2 6 , 8}$ & $\mathbf{7 0 4 , 1}$ \\
\hline & & & & & \\
\hline
\end{tabular}


W sytuacji kryzysowej awaryjne zaopatrzenie Rzeszowa w wodę po uwzględnieniu wszystkich ujęć dodatkowych zlokalizowanych na terenie Rzeszowa prezentuje się następująco:

- ujęcie WSK-PZL _ _ $\quad 1200,0 \mathrm{~m}^{3} / \mathrm{d}$

- ujęcie przy ul. Mazowieckiej _ _ $240,0 \mathrm{~m}^{3} / \mathrm{d}$

- ujęcie na osiedlu Słocina _ _ $\quad 465,0 \mathrm{~m}^{3} / \mathrm{d}$

- studnie publiczne _ _ $704,1 \mathrm{~m}^{3} / \mathrm{d}$

Suma $\quad 2609,1 \mathrm{~m}^{3} / \mathrm{d}$

W sytuacji kryzysowej dodatkowe ujęcia wody potrafią w pełni zaspokoić mieszkańcom Rzeszowa ilość wody związaną z fizjologią człowieka, a także z minimalną ilością wody. Niezbędna ilość wody zostanie wówczas zaspokojona w 97\%, natomiast warunek wymaganej ilość wody jak i ilości wody równy 50 $\mathrm{dm}^{3} / \mathrm{M} \cdot \mathrm{d}$ nie zostanie spełniony, dlatego też wymaga to wspomaganie zewnętrznymi dostawami wody.

\section{Podsumowanie}

- Jednym z nowych rozwiązań w Polsce dotyczących zaopatrzenia mieszkańców w wodę jest system „wodoerka”, którego używa m.in. MPWiK Jaworzno "Wodoerka" to urządzenie służące do paczkowania wody przeznaczonej do spożycia w higieniczne, sterylne worki foliowe o pojemności od 5 do $1000 \mathrm{dm}^{3}$, najczęściej są to pojemności od 5 do $10 \mathrm{dm}^{3}$, ze względu na łatwość transportu. Worek posiada uchwyt oraz kranik - spust wody. Ze względu na sterylność, brak dostępu powietrza do środka worka, a także system dezynfekcji, woda dłużej będzie przydatna do spożycia.

- MPWiK ma możliwość dowozu wody cysternami $\mathrm{z}$ następujących rzeszowskich instytucji: MPGK Rzeszów: 3 polewaczki o pojemności 7000 $\mathrm{dm}^{3}=21000 \mathrm{dm}^{3}$, KM PSP: 5 cystern o pojemności $2000 \mathrm{dm}^{3}=10000 \mathrm{dm}^{3}+$ 1 cysterna o pojemności $10000 \mathrm{dm}^{3}=41000 \mathrm{dm}^{3}$. Łącznie daje to możliwość dostarczenia $41000 \mathrm{dm}^{3}$ wody jednorazowo. Wykonanie przez w/w pojazdy założonych 8 kursów w ciągu doby pozwala na zabezpieczenie dowozu dodatkowo o ok. $328 \mathrm{~m}^{3} / \mathrm{d}$ wody.

\section{Bibliografia}

[1] Chowaniec J.: Freiwald P.: Patonki R.: Witek K.: Możliwości awaryjnego zaopatrzenia aglomeracji Rzeszowa w wody podziemne w warunkach wystąpienia zdarzeń ekstremalnych. Gaz, Woda i technika Sanitarna, nr 11. Wydawnictwo Sigma-NOT, Warszawa, 2006, s.11-13. 
[2] Rak J., Studziński A.: Ocena ilości wody z awaryjnych ujęć dal miasta Rzeszowa. Materiały IX Konferencji Naukowo-Technicznej „Ochrona jakości i zasobów wód. Wydawnictwo PZiTS o/Kraków, Zakopane, 2000, s.183-190.

[3] Tchórzewska-Cieślak B.: Risk in water supply system crisis management. Wydawnictwo Instytutu Technicznego Wojsk Lotniczych, Journal of Konbin, Warszawa, 2008, s.175-190.

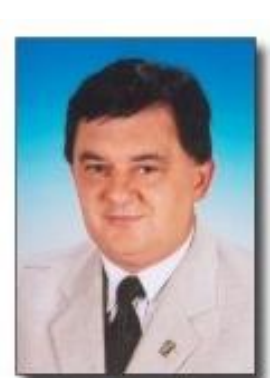

Prof. dr hab. Inz. Janusz Ryszard Rak w roku 1976 ukończyt studia na Wydziale Inżynierii Środowiska Politechniki Krakowskiej. Stopień doktora nauk technicznych uzyskat w 1986 r., stopień doktora habilitowanego w 1994 r., a w 2006 r. otrzymat tytut naukowy profesora nauk technicznych. Pracuje na stanowisku profesora zwyczajnego wPolitechnice Rzeszowskiej. Jest kierownikiem Katedry Zaopatrzenia w Wode $i$ Odprowadzania Ścieków. Specjalność - niezawodność i bezpieczeństwo systemów komunalnych oraz inżynieria uzdrowiskowa.

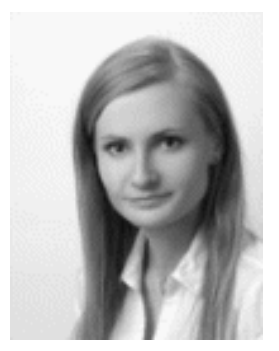

Mgr inż. Izabela Piegdoń w roku 2011 ukończyla studia na Wydziale Budownictwa i Inżynierii Środowiska Politechniki Rzeszowskiej. Pracuje na stanowisku asystenta $w$ Politechnice Rzeszowskiej w Katedrze Zaopatrzenia w Wodę i Odprowadzania Ścieków. Zainteresowania naukowe to niezawodność systemów zbiorowego zaopatrzenia $w$ wode, wykorzystywanie Geograficznych Systemów Informacji w zarzadzaniu systemami dystrybucji wody.

Mgr inz. Karolina Homa w roku 2012 ukończyta studia na Wydziale Budownictwa $i$ Inżynierii Środowiska Politechniki Rzeszowskiej w Katedrze Zaopatrzenia w wodę i Odprowadzania Ścieków. 


\title{
ASSET MANAGEMENT SUPPORTED BY RELIABILITY ENGINEERING
}

\section{ZARZĄDZANIE AKTYWAMI, WSPOMAGANE INŻYNIERIĄ NIEZAWODNOŚCI}

\author{
Adamantios Mettas
}

ReliaSoft Corporation Polska Sp. z o.o.

\begin{abstract}
Reliability methods are widely applied in design and manufacturing. Techniques such as FMEA, Life Data Analysis (aka Weibull analysis), Reliability Growth, System Analysis and Simulation, and FRACAS amongst others, represent the foundation of a solid reliability program. The collection of these tools and the process of deploying them appropriately is known as DFR in the design and manufacturing sector. Some of these tools and methods have also been applied in the maintenance sector (operators vs. manufacturers), but in many cases not as extensively. In this paper we propose a process for deploying different reliability tools and methodologies and we review their applicability in Asset Management. The proposed Asset Performance Management Process is linked to the DMAIC process and was inspired from the very successful DFR process. The proposed APM process lays down the different APM stages and the corresponding activities within each stage that need to be performed in order to achieve and sustain high asset reliability and availability, as well as reduce the operating costs.
\end{abstract}

Streszczenie: Metody niezawodnościowe sa powszechnie stosowane w projektowaniu i produkcji. Takie techniki jak FMEA, Analiza Danych Życiowych Life Data Analysis (zwana też analiza Weibulla), Wzrost Niezawodności, Analiza $i$ Symulacja Systemu oraz FRACAS reprezentuja podstawe solidnego programu niezawodnościowego. Zbiór tych narzędzi oraz proces ich odpowiedniego wdrażania jest $w$ sektorze projektowania i produkcji znany jako DFR. Niektóre $z$ tych narzędzi $i$ metod znalazly zastosowanie równiez $w$ sektorze konserwacji (między operatorami i producentami), lecz wielokrotnie nie $w$ tak dużym zakresie. $W$ niniejszym artykule proponujemy proces wdrażania różnych narzędzi $i$ metodologii niezawodnościowych, a także omawiamy ich przydatność w Zarządzaniu Aktywami. Proponowany Proces Zarządzania Wydajnościa Aktywów (APM) jest powiazany z procesem DMAIC $i$ zostat zainspirowany bardzo udanym procesem DFR. Proponowany proces APM rozmieszcza poszczególne etapy i czynności powiazane z każdym etapem, które musza zostać wykonane w celu osiagnięcia i utrzymania wysokiej niezawodności i dostępności aktywów, jak też redukcji kosztów operacyjnych. 
Asset management supported by reliability engineering

Zarzadzanie aktywami, wspomagane inżynieria niezawodności

\section{Introduction}

Reliability Engineering is a discipline that combines Practical experience, Maintenance, Safety, Physics and Engineering. In reliability engineering, observational data is combined with experience to create models in order to control the behavior of the equipment, optimize its performance, and minimize the Life Cycle and Operational Costs.

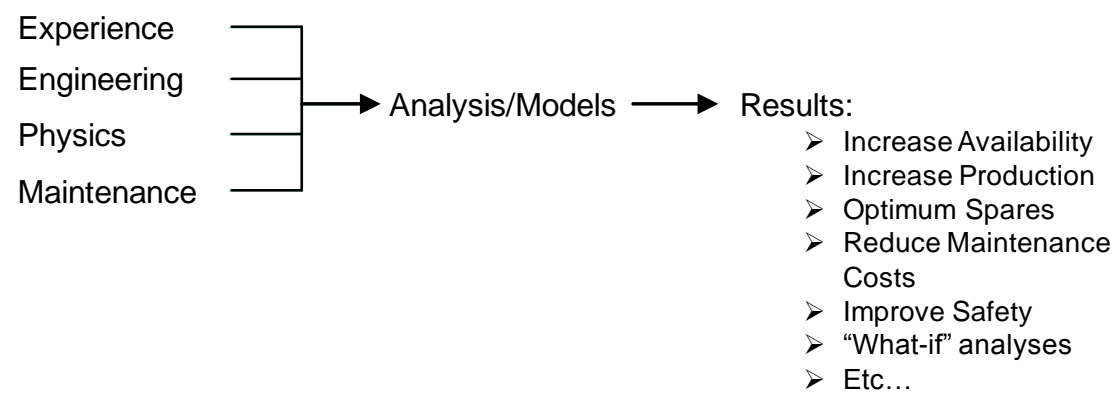

Fig. 1 Reliability Engineering

It is important to note that reliability engineering is not simply statistics, neither always quantitative. Even though the quantitative analysis plays a major role in the reliability discipline, many of the available tools and methods are also process oriented/related. It is therefore useful to separate these methods and tools into Quantitative and Qualitative categories. In the Quantitative category, the typical tools are:

- Life Data Analysis, aka, distribution analysis or Weibull analysis.

- Reliability Growth.

- Accelerated Testing, aka, Life-Stress analysis.

- System modeling (Reliability Block Diagams).

- Simulation.

- Fault Tree Analysis.

- Design of Experiments (DOE).

- Standards Based Predictions.

In the Qualitative category, the typical tools are:

- FMEA/FMECA

- RCM

- FRACAS

- Root Cause Analysis (RCA).

In this paper we focus on the reliability engineering tools and methods, from the above list, that are most applicable in Asset Performance Management, and how and when each of them should be deployed in order to maximize their effectiveness. 


\section{The APM Process}

Understanding when, what and where to use the wide variety of reliability engineering tools available will help to achieve the reliability mission of an organization. And this is becoming more and more important with the increasing complexity of systems as well as the complexity of the methods available for determining their reliability. With such increasing complexity in all aspects of asset performance management, it becomes a necessity to have a well defined process for incorporating reliability activities. Without such a process, trying to implement all of the different reliability activities involved in asset management can become a chaotic situation, where different reliability tools are deployed too late, randomly, or not at all, resulting in the waste of time and resources as well as constantly operating in a reactive mode.

Managers and engineers have come to this realization and a push for a more structured process has been seen in recent years. The circumstances are very similar to what happened with the "Quality Assurance" discipline back in the 1980s, which spawned successful processes such as Six Sigma and Design for Six Sigma (DFSS). In most recent years the same realization occurred in "Product Development" with the resulting Design for Reliability (DFR) process. It is thus natural that we looked into these successful processes in order to create a process for Asset Performance Management, and it's based on the DMAIC methodology. DMAIC is used for projects aimed at improving an existing business process, and includes five phases:

- Define the problem, voice of the customer and the project goals.

- Measure key aspects of the current process and collect relevant data.

- Analyze the data to investigate and verify cause-and-effect relationships. Seek out root cause of the defect under investigation.

- Improve or optimize the current process based upon data analysis and standard work to create a new, future state process. Set up pilot runs to establish process capability.

- Control the future state process to ensure that any deviations from target are corrected before they result in defects. Control systems are implemented such as statistical process control, production boards, and visual workplaces - and the process is continuously monitored.

Starting from these process phases, we determined the asset performance stages within each of these phases, and we subsequently derived the reliability activities (methods and tools) as they pertain to asset management.

The proposed process can be used as guide to the sequence of deploying the different tools and methods involved in an asset reliability program in order to maximize their effectiveness and to ensure high reliability. This process can be adapted and customized based on the specific industry, corporate culture and other existing processes within a company. In addition, the sequence of the activities within the APM process will vary based on the nature of the asset and the amount 
Asset management supported by reliability engineering Zarzadzanie aktywami, wspomagane inżynieria niezawodności

of information available. It is important to note that even though this process is presented in a linear sequence, in reality some activities would be performed in parallel and/or in a loop based on the knowledge gained as a project moves forward. The different phases of this proposed process and the activities within each phase are reviewed next.

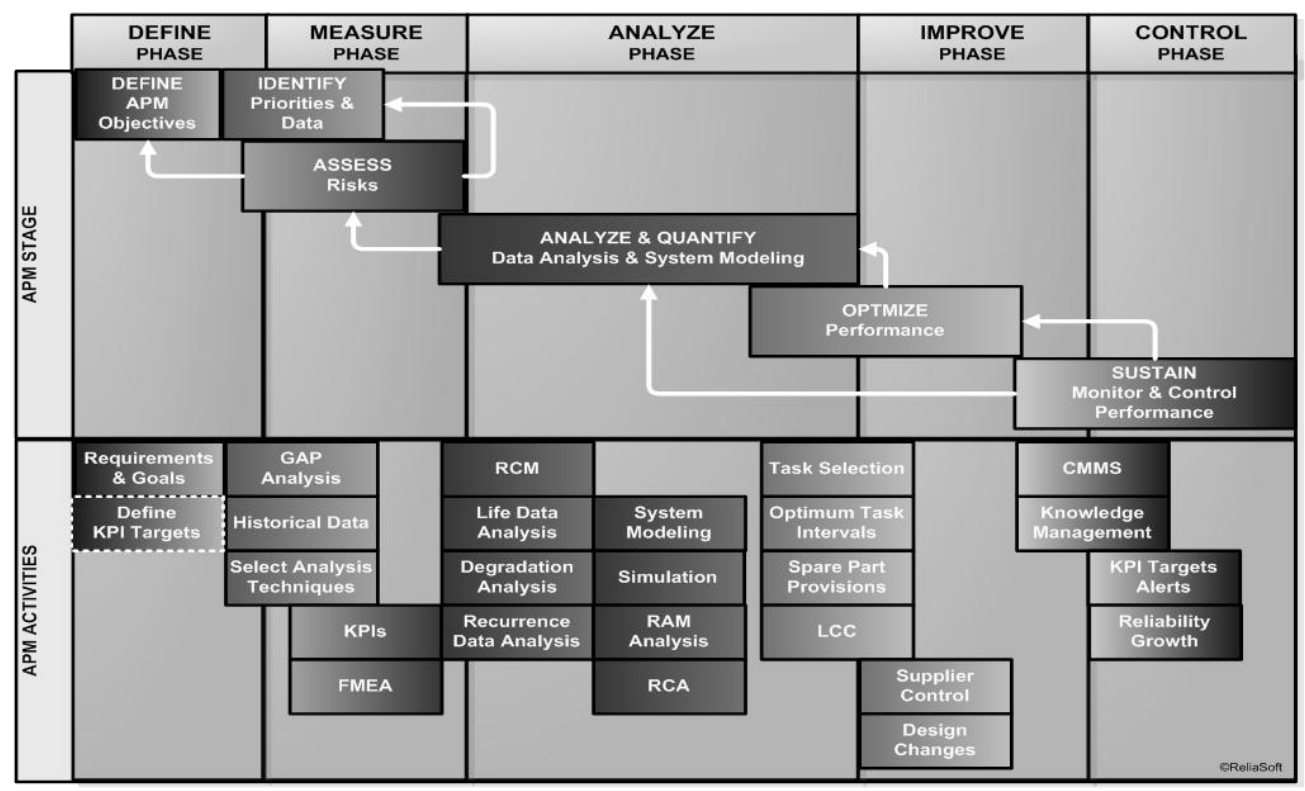

Fig. 2 The proposed APM Process

\section{Define Phase}

The first step of any project is to define its objectives. It is a very key activity since in this step the requirements and goals will be defined. The activities performed in this phase will provide a direction for all future phases and activities to be performed. All too often projects are initiated without a clear direction and without a clear definition of the objectives. This leads to poor project execution. Therefore, it is essential that we:

- Define the Asset Performance/Reliability objectivities.

- Define requirements and goals.

- Define the scope of the analysis.

- Determine budgetary and time constraints.

- Determine the recourses and their responsibilities.

- Plan activities and set criteria for success.

- Define the appropriate Key Performance Indicators (KPIs) for the organization.

- Define the KPI targets. 


\section{Define KPIs}

A performance indicator or key performance indicator (KPI) is a measure of performance. Such measures are commonly used to help an organization define and evaluate how successful it is, typically in terms of making progress towards its long-term organizational goals.

It is very important that time is spent at the start of a project to define the KPIs that are important to the organization, as well as review existing performance indicators to determine their usefulness and/or how they are obtained. Reviewing and understanding the current indicators can also provide a benchmark for judging the success of a project.

KPIs can be specified by answering the question, "What is really important to different stakeholders?" As such, different levels of performance indicators can be specified, and aligned to the organization's business objectives.

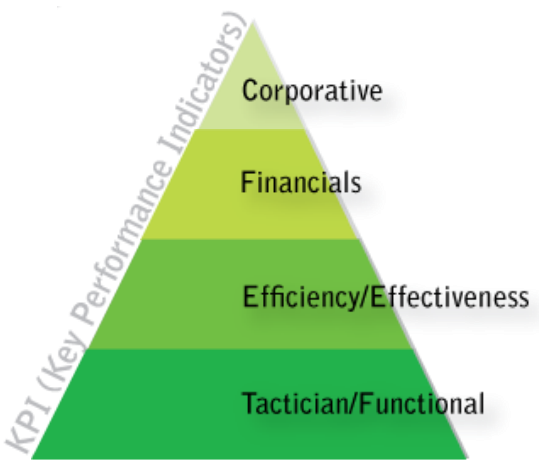

Fig. 3 KPI Categories

Another aspect of the criticality of defining the KPIs at this stage, is the impact on the required data for obtaining these KPIs. In other words, the chosen KPIs will also determine which data and information needs to be reviewed or captured in the future.

Finally, it is also important to note that KPIs should be monitored, in order to assess the present state of the business and to assist in prescribing a course of action

\section{Measure Phase}

Prior to conducting any type of reliability analysis, it is important to collect all the required data and information. In addition, it is crucial to also determine what kind of data is available, and where they reside. The type of data and their availability will determine which analyses can be performed, as well as identify future steps for gathering the right type of data necessary. Therefore, the typical first step in this 
Asset management supported by reliability engineering

Zarzadzanie aktywami, wspomagane inżynieria niezawodności

phase is to perform a "Gap Analysis," then we seek the Data, and based on the results of these two steps, we select the Appropriate Analysis techniques.

\section{Gap Analysis}

The purpose of a Reliability "Gap" Assessment is to identify the shortcomings in achieving the Asset Performance Management objectives so that a Reliability Program Plan can be properly developed. Many companies implement APM tasks without first understanding what drives reliability task selection. The "gaps" are those issues or shortcomings that, if closed or resolved, would move the company in the direction of achieving its APM targets. In addition, during this activity, the available data sources can be identified, and if inadequate, resort to other sources of information. During the gap assessment, answers to the following questions are sought:

- Identifying reliability activities currently in place. For example, is there an existing RCM available? Has it been successfully executed?

- What personnel are currently supporting reliability activity?

- What procedures document current reliability and APM practices?

- How is reliability data currently collected (e.g. CMMS, FRACAS, Production Losses, etc.)?

- How is asset reliability and performance currently computed (i.e. methods and tools)?

- Can we compute all the KPIs we defined?

\section{Data}

Data, and specifically Failure Data, worth gold to a reliability engineer. On the flip side, the more failures the worst the condition of the asset is. In any case, data represent the most important aspect in performing Quantitative analyses. It is thus crucial that data is collected and categorized appropriately. This data will be used in computing the different KPIs, as well as in performing a variety of reliability calculations.

In addition to Failure data, the Repair duration is also a very important input in the R\&M model, since the availability of the equipment is dependent on it. By having this information, the availability of the system can be computed. In fact, the different types of data/information typically necessary for a thorough reliability analysis of assets are:

- Failure times/intervals.

- Repair durations.

- Failure codes/IDs (cause of failure).

- Current maintenance task types and intervals.

Additional information that would improve the analysis if available, include:

- Throughput/capability of each equipment.

- Repair Crew availability (e.g. number of crews and corresponding logistic delays).

- Repair Costs (parts, labor, etc.). 
- Spare parts availability and costs.

- Inspection policies (e.g. condition monitoring).

There are multiple sources of data. For example, Failure data can be obtained from maintenance records (work orders, downtime logs, etc.), from OEM reliability specs, or from generic equipment data.

For existing equipment historical data can be used. There may be a great deal of historical data that has been generated over many years It is necessary to find out where these data reside, and which data can assist in meeting our objectives.

Once the sources have been identified, the quality and consistency of the data must be analyzed. One of the most common problems is the quality of the collected data. All too often, even though records are kept, it turns out that the data are not really usable. Most common problems with available data include:

- Not specifying the cause of the failure (e.g. the component, the part, the equipment).

- Not having the appropriate system hierarchy in the CMMS for reliability data purposes. For example, in many CMMSs the asset hierarchy is setup in such way which prevents the "roll-up" of failure frequency information from the component to the subsystem to the equipment. So we can see that a "valve" failed for instance, but we cannot see where this valve belongs (for equipment level analysis). In addition, if there is another valve failure, the data analyst cannot determine if it was the same valve that failed before.

- No data tracking system.

- Poor implementation of work orders workflow. For example, work orders left opened much after the work has been completed, providing a false indication of repair duration if this data was taken as repair duration data.

- CMMS/EAM in place, but not capturing production loss data.

- Inspection data not captured (e.g. inspection intervals and results of each inspection). This data can be very useful in determining Safety Integrity Levels (SIL), and in Risk Based Inspection (RBI) methodology.

To prevent/avoid such problems, it is also imperative to implement actions for ensuring a good data collection process and management.

Assuming all the relevant information and data is available, then the System Availability, Downtime, Production Output (throughput), Maintenance costs, etc. can be estimated using Simulation.

\section{Select Analysis Techniques}

Selecting the appropriate analysis technique depends on the available data (determined previously), and on what needs to be optimized (specified in the Define phase). 
Asset management supported by reliability engineering

Zarzadzanie aktywami, wspomagane inżynieria niezawodności

\section{Analyze Phase}

Depending on the previous results, the appropriate analysis should be executed in order to optimize the performance of the asset.

In the next sections we will present the objectives, applications and benefits of each analysis that can be used in Asset Performance Management

\section{RCM}

Reliability Centered Maintenance (RCM) analysis provides a structured framework for analyzing the functions and potential failures for physical assets in order to develop a scheduled maintenance plan that will provide an acceptable level of operability, with an acceptable level of risk, in an efficient and cost effective manner.

RCM can be:

- Quantitative and based on the reliability analysis (as explained in prior sections).

- Qualitative, following a strict step-by-step methodology as dictated by many RCM probationers.

- A combination of both of the above.

A lot has been written on RCM methodology and its benefits, and it's outside the scope of this paper to get into the details. However, it's worth mentioning some of the widely accepted befits of RCM, which include:

- Prioritize actions based on equipment criticality (multiple criticality classifications exist).

- Reduce and ultimately eliminate chronic failures and reliability problems.

- Document maintenance program and practices.

- Reduce unscheduled maintenance.

- Reduce risk.

- Document reasons for current activities and for future changes.

\section{Life Data Analysis}

Life Data Analysis refers to the application of statistical methods in determining the behavior of the life of equipment based on life data. Life Data Analysis utilizes sound statistical methodologies to build probabilistic models (i.e. distributions) from life data, such Weibull, Lognormal, etc. The models are then utilized to compute the item's reliability, make predictions, as well as revise or determine maintenance policies and maintenance task intervals. These models should be applied at the Lowest Replaceable Unit (LRU) level. 
Benefits:

- Understand failure patterns.

- Understand life expectancy of components.

- Understand repair duration patterns.

- Use these models in the RAM analysis.

- In next phases of the APM process (Improve) utilize the results of this analysis for spare part provisions, determine optimum maintenance intervals, make design changes, etc.

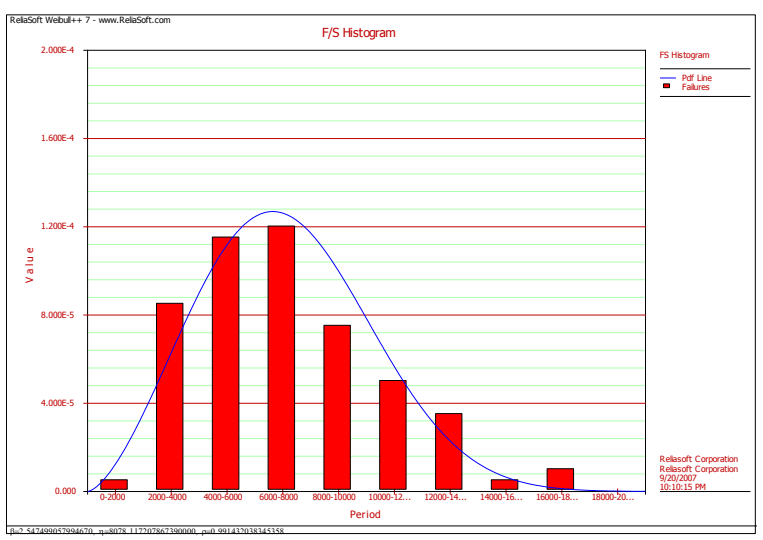

Fig. 4 Statistical Distribution fitted to Failure Data

\section{Degradation Analysis}

Another way of obtaining reliability metrics involves a type of analysis known as "degradation analysis." Degradation analysis involves the measurement and extrapolation of degradation or performance data and can be directly related to the presumed failure of the item in question.

Many failure mechanisms can be directly linked to the degradation of part of the product. Assuming that this data is captured (CBM data), degradation analysis allows the analyst to extrapolate to an assumed failure time based on the measurements of degradation or performance over time. This analysis essentially determines the P-F curve, and the results can be used to:

- Understand failure patterns

- Understand life expectancy of components

- Build life distributions, which will be later used in the RAM analysis and optimizations (Improve phase).

\section{Recurrent Events Data Analysis}

The Recurrent Event Data Analysis is different than the "traditional" life data analysis (or distribution analysis), as it's applied on equipment and system level data. In other words, the data is used to build a model at the Equipment, rather than the component/part level. In Distribution analysis, time-to-failure is used, 
Asset management supported by reliability engineering

Zarzadzanie aktywami, wspomagane inżynieria niezawodności

where each failure represents an independent event. In the Recurrent Events Data analysis, the cumulative operating time and the cumulative number of events are data utilized. The models in this case are used to track the behavior of the "Number of Events" over time and understand the "Effectiveness" of repairs.

The most commonly used models for analyzing Recurrent Event Data are the NHPP and the General Renewal process (GRP).

\section{System Modeling/RAM Analysis}

An RAM analysis typically starts from the creation of a System Diagram, which represents the overall process and the corresponding major subsystems. This is diagram is known as a Reliability Block Diagram (RBD).

The next step is to expand the major subsystems into subsubsystems, and keep repeating until the level where reliability information is available (ideally at the LRU level) has been reached.

The analysis will be based on the configuration (represented by the diagrams) of these items, and their Failure and Repair duration properties. The Failure properties (i.e. Reliability) determine the frequency of occurrence of failure of each LRU, and the repair duration determines the downtime. Based on the configuration the effect on the overall system is determined. The effect on the overall system could be that the whole system fails, or a percent reduction in the total output of the system (throughput).

To perform a complete RAM analysis, the following data and information is required:

- System Diagrams/Drawings (P\&IDs).

- Failure data.

- Repair duration data.

- Process capabilities of individual machines.

- Repair costs.

- Maintenance types and intervals.

- Repair Crew availability (e.g. number of crews and corresponding logistic delays).

- Spare parts availability and costs.

The results of such an analysis include (at different levels, e.g., asset, equipment, etc.):

- Availability

- Downtime

- Number of failures

- Spares usage

- Production output

- Life Cycle Cost

Having this model will allow us in the "Improve" phase to perform "what-if" analyses and investigate the effect on the above results of any proposed changes/improvements. 


\section{Root Cause Analysis}

RCA is a methodology to logically analyze failure events, identify all the causes (physical, human, and primary) and define corrective actions to prevent their reoccurrence. It is a critical activity in understanding failures and being able to determine corrective actions. Without a formal RCA procedure, the wrong remedies might be frequently implemented.

\section{Improve Phase}

The main objective of an APM process is to drive improvements, thus this phase represents the most critical step. During this phase the objective is to identify the improvements that can increase the performance of the asset and optimize it, including:

- Define the most appropriate maintenance policy.

- Determine the optimum maintenance task intervals.

- Determine adequate spare part provisions.

- Apply design changes when it's necessary/feasible.

- Drive new requirements to suppliers.

- Add to the simulation cost information to run a dynamic life cycle cost (LCC) analysis.

In the case of optimizing the interval of performing a Preventime Maintenance action (PM), the following equation is used:

$$
\operatorname{CPUT}(t)=\frac{C_{P} \cdot R(t)+C_{U} \cdot[1-R(t)]}{\int{ }_{0}^{t} R(s) d s}
$$

where:

$\begin{aligned} \mathrm{R}(\mathrm{t})= & \text { reliability at time } \mathrm{t} . \text { This is determined by performing the Life Data } \\ & \text { Analysis, using the data described in Section "Data". } \\ \mathrm{CP}= & \text { PM Cost per Incident (planned maintenance) } \\ \mathrm{CU}= & \mathrm{CM} \text { Cost per Incident (unplanned maintenance) }\end{aligned}$ The equation is solved for time, $t$, that results in the least possible cost per unit of time.

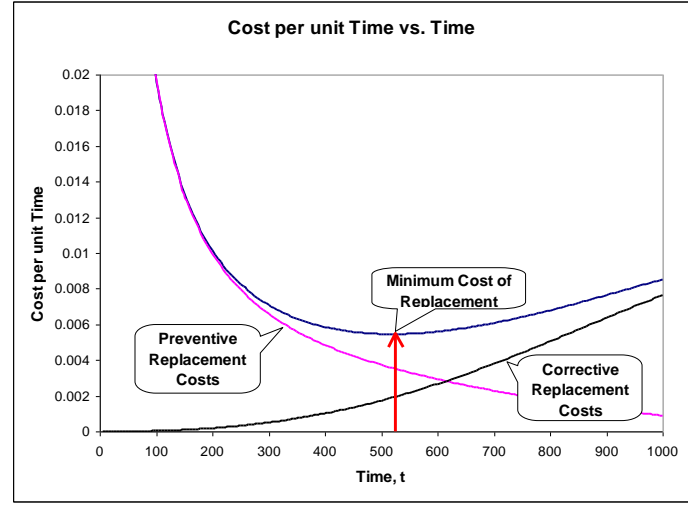

Fig. 5 Optimum PM Interval 
Asset management supported by reliability engineering

Zarzadzanie aktywami, wspomagane inżynieria niezawodności

\section{Control Phase}

Every time the APM process is initiated, it is imperative to execute activities which can Sustain the achieved results. As such, certain activities to monitor and control the performance need to be applied, including:

- Implement the new maintenance tasks and new intervals into the CMMS.

- Seek continuous improvement, i.e., new KPI targets can be defined and monitored

- Monitor the asset's performance. Reliability growth analysis needs to be implemented. For example the Crow-AMSAA model is typically used to model the reliability performance of the asset(s) over time (e.g., month-tomonth).

Another critical function in this phase, is sustaining the knowledge acquired by all previous activities, as well as retaining the information that have lead to a particular action/change. Failing to retain this knowledge can lead to "re-inventing the wheel" down the road, as well as repeating past mistakes. Different activities (including analysis, action plans, and decisions) should be registered properly and stored in a location where other professionals involved in the asset's management can access in the future.

\section{Summary}

In this paper we reviewed the role of Reliability Engineering in Asset Performance Management, and we proposed an APM Process for deploying all the different tools and methods available. The proposed process is based on the DMAIC methodology, and lays down the steps and activities for a more formal and structured deployment of the different reliability tools and methods, where they can be most effective. The process is general enough to be easily adopted by different industries and to use in conjunction with current reliability practices.

\section{References}

[1] Developing Performance Indicators for Managing Maintenance, Terry Wireman, 1998

[2] Life Data Analysis Reference, ReliaSoft Publishing, 2005

[3] System Reliability Reference, ReliaSoft Publishing, 2007

[4] Mettas, A., and Zhao, W., "Modeling and Analysis of Repairable Systems with General Repair, "RAMS January 24-27, 2005, Alexandria, VA.

[5] www.weibull.com 


\title{
DIFFERENT ANALYSIS PROCEDURES FOR COMPUTING THE RELIABILITY OF REPAIRABLE SYSTEMS
}

\section{RÓŻNE PROCEDURY ANALIZY DLA OBLICZANIA NIEZAWODNOŚCI SYSTEMÓW PODLEGAJĄCYCH NAPRAWIE}

\section{Adamantios Mettas}

\begin{abstract}
This paper will review the different analysis scenarios that can be used when examining the reliability of repairable systems. Five different methods will be reviewed, specifically:

1) Using the mean value of the times between failure (TBFs) at the system level.

2) Using the distributions of the components of the system and creating a reliability block diagram $(R B D)$.

3) Using the distribution of the times between failure (TBFs) at the system level.

4) Using the system level failure data and fitting the non-homogeneous Poisson process (NHPP) model.

5) Using the system level failure data and fitting the general renewal process (GRP) model.

In the paper, the five different methods will be discussed (brief background), and conclusions about the applicability and accuracy of each method will be given. In addition, this paper can be used to further understand the assumptions behind each analysis method, the data required and the type of results that can be obtained, thus assisting analysts in choosing the most appropriate method.
\end{abstract}

Streszczenie: Niniejszy artykut omawia różne scenariusze analizy, które można zastosować podczas badania niezawodności systemów podlegajacych naprawie. Omówionych zostanie pięć różnych metod:

1) Użycie średniej wartości czasu między usterkami (TBFs) na poziomie systemu.

2) Użycie rozktadu elementów systemu $i$ utworzenie schematu blokowego niezawodności (RBD).

3) Użycie rozkładu czasów między usterkami (TBFs) na poziomie systemu.

4) Uzycie danych dotyczacych usterek na poziomie systemu $i$ dopasowanie niehomogeniczne go modelu procesu Poissona (NHPP).

5) Użycie danych dotyczacych usterek na poziomie systemu i dopasowanie modelu procesu ogólnego odnawiania (GRP).

$W$ artykule omówionych zostanie pięć różnych metod (krótkie wprowadzenie) i przedstawione zostana wnioski dotyczace możliwości zastosowania i dokładności każdej z nich. Poza tym artykut ten może zostać wykorzystany do dokładniejszego zrozumienia założeń każdej metody analizy, wymaganych danych oraz rodzaju wyników które można porównać, co czyni go pomocnym w doborze najbardziej odpowiedniej metody. 
Different analysis procedures for computing the reliability of repairable systems Różne procedury analizy dla obliczania niezawodności systemów podlegajacych naprawie

\section{Introduction}

This paper reviews the different analysis scenarios that can be used when examining repairable systems. Five different methods will be reviewed, using a hypothetical system, specifically:

1) Using the mean value of the times-between failures at the system level.

2) Using the distribution of the times-between failures at the system level.

3) Using the distributions of the components of the system and creating a Reliability Block Diagram (RBD).

4) Using the system level failure data and fitting the Non-Homogeneous Poisson Process (NHPP) model.

5) Using the system level failure data and fitting the General Renewal Process (GRP) model.

The following procedure will be used to create failure data and compare results:

A. A hypothetical system will be created using a RBD and with known component failure distributions. This will represent a system where the True reliability and expected failures are known.

B. The repair duration will be considered negligible for the purpose of this comparison.

C. A simulation will be performed on this system for a defined mission duration, and the events (failures) during the simulation, and the associated responsible part, will be extracted.

D. Two more such simulations will be performed (total of 3, with different mission durations), which in a way would represent 3 fielded systems of different operational times/ages.

E. The results from these three simulations will then be analyzed with above mentioned five different analysis methods.

\section{Simulation}

For simplicity, we chose a Racing Car for our hypothetical system. The system is broken down to 2 major subsystems: Front Assembly and Rear Assembly.

The Front Assembly is comprised of:

- Front Brakes

- Front Suspension

The Rear Assembly is comprised of:

- Rear Brakes

- Rear Suspension

- Engine

- Transmission 
The RBDs for the system are:

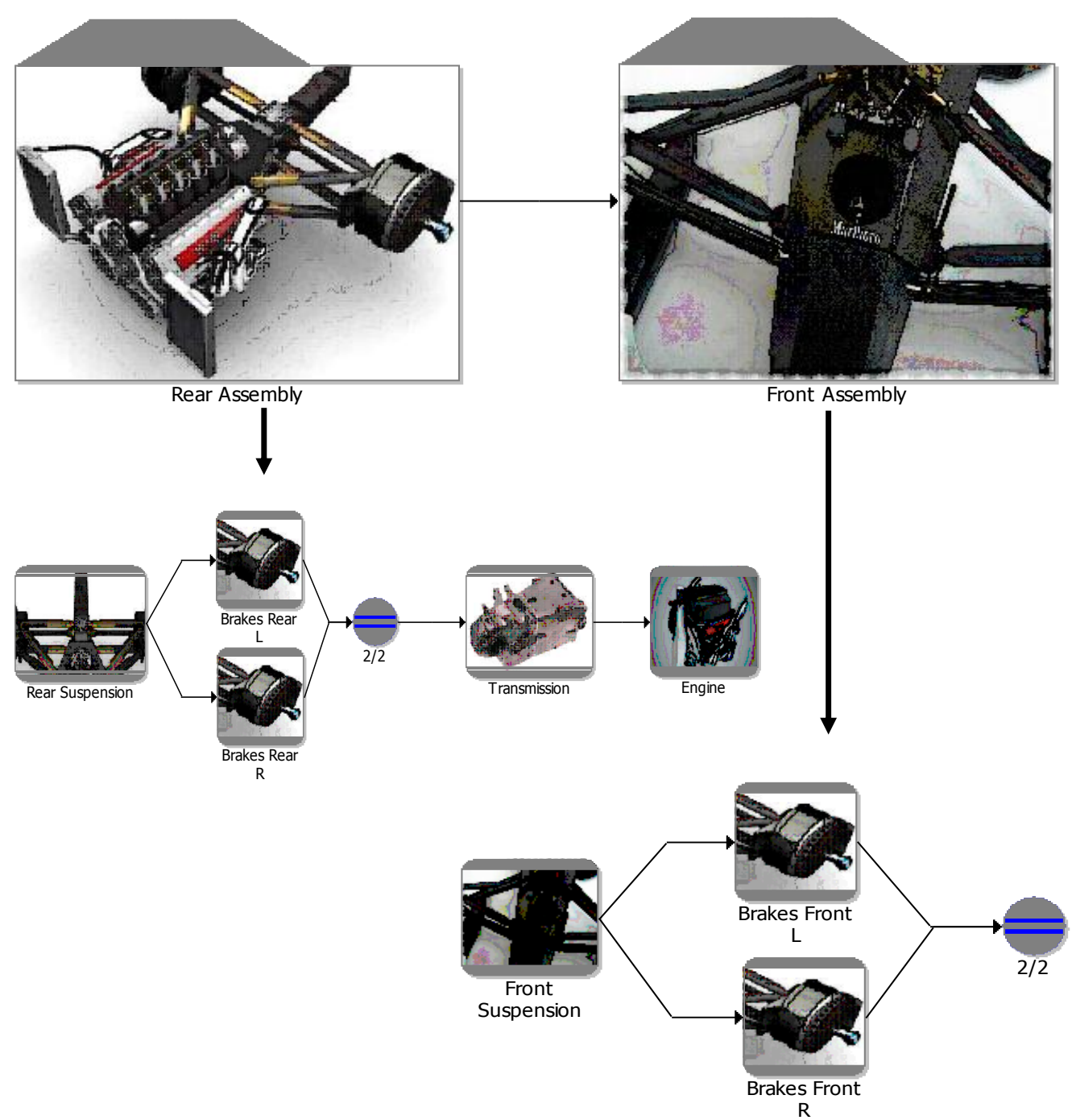

The following failure distributions and corresponding parameters were set to represent the "True" reliability behavior of these components:

Table 1: True failure distributions for the different components of the system

\begin{tabular}{|l|l|r|r|}
\hline Component & Distribution & Parameter 1 & Parameter 2 \\
\hline Brakes Front & Weibull & 5,8 & 474 \\
\hline Front Suspension & Lognormal & 7,215 & 0,563 \\
\hline Brakes Rear & Weibull & 5,8 & 556 \\
\hline Engine & Weibull & 2,6 & 1230 \\
\hline Rear Suspension & Weibull & 2,14 & 1606 \\
\hline Transmission & Lognormal & 6,91 & 0,5281 \\
\hline
\end{tabular}


Different analysis procedures for computing the reliability of repairable systems Różne procedury analizy dla obliczania niezawodności systemów podlegajacych naprawie

In Table 1, for the Weibull distribution, Parameter 1 is Beta and Parameter 2 is Eta. For the Lognormal distribution, Parameter 1 is the LnMean, and Parameter 2 is the LnStd.

\section{Simulation Assumptions}

Three simulations were performed, based on the above RBD and the distributions of Table 1, the first for a mission time of $2500 \mathrm{Km}$, the second for $1976 \mathrm{Km}$ and the third for $800 \mathrm{Km}$. In addition, and to make the simulation more realistic, Preventive Maintenance was performed on the brakes every $305 \mathrm{Km}$. The idea here is that the RBD represents an actual system that operates in the field, and since we run three simulations, each simulation represents one fielded system. The failure distributions that will generate the failures are known, but we'll pretend that we don't know them, and try to estimate the reliability using the five methods mentioned in the introduction of this report. The Preventive Maintenance Policy was added in order to replicate a more realistic scenario of systems operating in the field.

\section{Simulation Results}

After the three simulations were run, the following events were obtained:

\begin{tabular}{|c|c|c|c|c|c|}
\hline \multicolumn{2}{|l|}{$\begin{array}{l}\text { System1 } \\
\text { Age=2500Km }\end{array}$} & \multicolumn{2}{|l|}{$\begin{array}{l}\text { System2 } \\
\text { Age=1976Km }\end{array}$} & \multicolumn{2}{|l|}{$\begin{array}{l}\text { System3 } \\
\text { Age }=800 \mathrm{Km}\end{array}$} \\
\hline Time-to-Event & Component & Time-to-Event & Component & Time-to-Event & Component \\
\hline 249.8556746 & engine & 305 & PM Brakes & 305 & PM Brakes \\
\hline 305.00001 & PM Brakes & 610.0001 & PM Brakes & 453.8681512 & rear suspension \\
\hline 584.2324998 & front suspension & 872.4111452 & engine & 610.00011 & PM Brakes \\
\hline 610.00012 & PM Brakes & 899.7569744 & right front brake & 743.4900418 & transmission \\
\hline 915.00022 & PM Brakes & 899.7569844 & PM Brakes & & \\
\hline 971.9650444 & engine & 1204.757074 & PM Brakes & & \\
\hline 1220.00033 & PM Brakes & 1371.701827 & right front brake & & \\
\hline 1525.00043 & PM Brakes & 1371.701837 & PM Brakes & & \\
\hline 1830.00053 & PM Brakes & 1470.438019 & engine & & \\
\hline 1861.689518 & front suspension & 1572.565067 & rear suspension & & \\
\hline 1994.56836 & rear suspension & 1676.701947 & PM Brakes & & \\
\hline 2127.083186 & transmission & 1754.884827 & transmission & & \\
\hline 2134.282155 & right rear brake & & & & \\
\hline 2134.282165 & PM Brakes & & & & \\
\hline 2186.903602 & engine & & & & \\
\hline 2439.282265 & PM Brakes & & & & \\
\hline
\end{tabular}

As seen from Table 2, for each simulation the event time was recorded, as well as the corresponding component that initiated an event. We will now assume that this is all we know about the design, and that each simulation represents a system in operation, where the first system operated for $2500 \mathrm{Km}$ so far, system 2 for $1976 \mathrm{Km}$ and system 3 for $800 \mathrm{Km}$. Note that the event times are in a cumulative scale. 


\section{Analyses and Indyvidual Results}

\section{Using the Mean Value of the System's Times-Between-Failures}

In this approach the objective is to estimate the MTBF of the Design (system), and based on this estimation possibly make predictions about future events. Under this model, we only look at the Times-Between-Failures for each system, or,

Table 3: Time-Between-Failures (TBF) for each System

\begin{tabular}{|c|c|c|c|c|c|}
\hline \multicolumn{2}{|l|}{$\begin{array}{l}\text { System1 } \\
\text { Age=2500Km }\end{array}$} & \multicolumn{2}{|l|}{$\begin{array}{l}\text { System2 } \\
\text { Age }=1976 \mathrm{Km}\end{array}$} & \multicolumn{2}{|l|}{$\begin{array}{l}\text { System3 } \\
\mathrm{Age}=800 \mathrm{Km}\end{array}$} \\
\hline Time-to-Event & Time-Between-Failures & Time-to-Event & Time-Between-Failures & Time-to-Event & Time-Between-Failures \\
\hline 249.8556746 & 249.8556746 & 872.4111452 & 872.4111452 & 453.8681512 & 453.8681512 \\
\hline 584.2324998 & 334.3768252 & 899.7569744 & 27.3458292 & 743.4900418 & 289.6218906 \\
\hline 971.9650444 & 387.7325446 & 1371.701827 & 471.9448526 & & \\
\hline 1861.689518 & 889.7244736 & 1470.438019 & 98.736192 & & \\
\hline 1994.56836 & 132.878842 & 1572.565067 & 102.127048 & & \\
\hline 2127.083186 & 132.514826 & 1754.884827 & 182.31976 & & \\
\hline 2134.282155 & 7.198969 & & & & \\
\hline 2186.903602 & 52.621447 & & & & \\
\hline
\end{tabular}

Notice that in Table 3 all the Preventive Maintenance events have been removed, since they don't represent failures.

There are two ways to utilize the TBF data of Table 3 in order to obtain an MTBF. The first is to simply sum all the TBFs and divide by the total number of events, or,

$$
M T B F=\frac{\sum_{i=1}^{N} t_{i}}{N}
$$

where:

$t_{i}=$ TBF from each system

$N=$ Total number of events from all systems

The MTBF calculated using this approach could be very misleading, since it assumes a random failure behavior (i.e. constant Rate of Occurrence of Events, aka Failure Rate). If the system exhibits an aging pattern (wear-out), or an infant mortality pattern, this equation will average out all the TBFs and the Mean could be overestimated in the first case, or underestimated in the latter.

Due to this, an improved estimator is to obtain the MTBF from the distribution of the TBFs. Under this approach a distribution is fitted to the TBFs which will represent the behavior of the TBFs. In addition, the time between the last failure of each system and the "current age" of each respective system can be included in the model as "Suspensions .".

\footnotetext{
${ }^{1}$ Note that the ability to include/consider the Suspensions is a main difference between this approach and the simplified method given by Eqn. 1 .
} 
Different analysis procedures for computing the reliability of repairable systems Różne procedury analizy dla obliczania niezawodności systemów podlegajacych naprawie

For this particular example, the data is entered in Weibull++, and the following model is obtained:

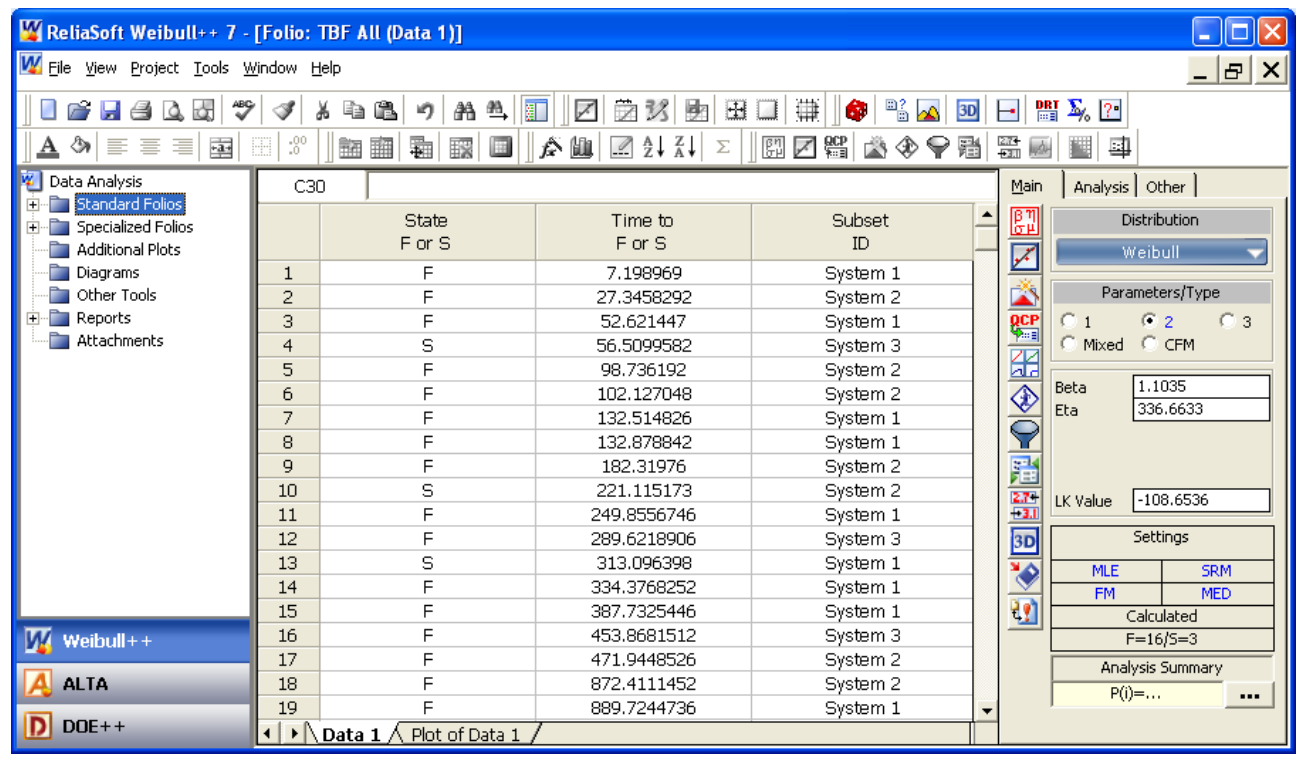

Notice, that for each system there is one Suspension which is the time between the last event and the current age of the system.

Under this analysis, and for this example, the Best-fit distribution is the Weibull, with beta $=1.11$ and eta $=337 \mathrm{Km}$. Based on this distribution, the MTBF can be calculated, or,

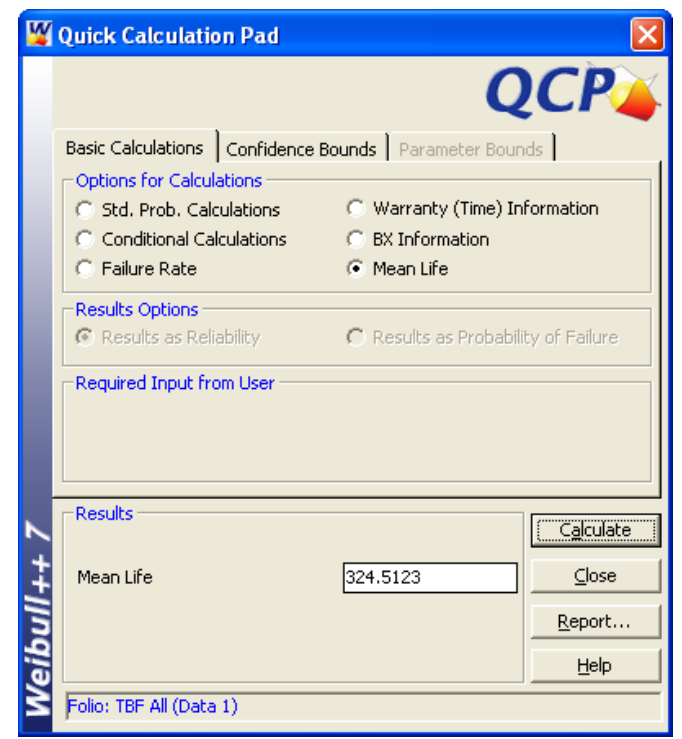


Therefore, in this example, MTBF $=324.5 \mathrm{Km}$. This estimate is preferred over the one using Eqn. 1, because the behavior of the TBFs is considered, and it's based on a best-fit model rather than assuming a constant rate of occurrence of failures (ROCOF). (Note that a constant ROCOF is similar to assuming an exponential distribution, or more correctly a Homogeneous Poisson Process).

However, caution must be taken when using this approach, because even though this analysis represents a better estimate than the one given by Eqn. 1, it is still an average, and as it will be shown later, averages work well when sufficient data is present AND when systems have reached a "Steady State" AND when predicting future events.

A second caution is regarding the misuse of this approach. In many cases, analysts misinterpret this model as being the Failure Distribution of the System, and perform additional estimations, such as Reliability, BX calculations, etc. These types of results are incorrect, since the model simply describes the behavior of the TBFs, and in essence it's a model of the MTBF. From this model, and in addition to the MTBF, we can obtain, for example, what percentage of the TBFs is within a given time range, BUT this does NOT represent a Reliability/Unreliability calculation. For example, if we compute $\mathrm{P}(\mathrm{t}=200 \mathrm{~km})$, for this model we get $43 \%$. This does NOT mean that the probability of failure of the system is $43 \%$, rather that $43 \%$ of the TBFs were in the order of $200 \mathrm{Km}$ or less. Obviously, this is very different than a Reliability/Unreliability statement. Also notice, that this statement is invariant of the chronological order of the TBFs, and the $43 \%$ of the TBFs that are less or equal to $200 \mathrm{Km}$ could have occurred at the beginning of the life of the system, at the latter stages, or just randomly...all we can tell from this model is that we expect $43 \%$ of time between events to be less or equal to $200 \mathrm{Km}$. The following graphic explains this point. In this graphic a chronological order of failure events of a system is depicted. In the graphic, $T_{i}$ represents the cumulative time to event, and $t_{i}$ represents the time-between events. In addition, the vertical red line represents the time when the system has accumulated $200 \mathrm{Km}$ of operation, and all the times between events that are less or equal to $200 \mathrm{Km}$ are contained within the circle. If we were to estimate the Reliability at $200 \mathrm{Km}$, then it is defined as the probability that the system will operate for $200 \mathrm{Km}$ without a failure. It can be easily seen from the graph, that this is different than percentage of TBFs whose order of magnitude is less or equal to $200 \mathrm{Km}$ (circled events). The percentage of events included in this circle is what was calculated above to be $43 \%$. 


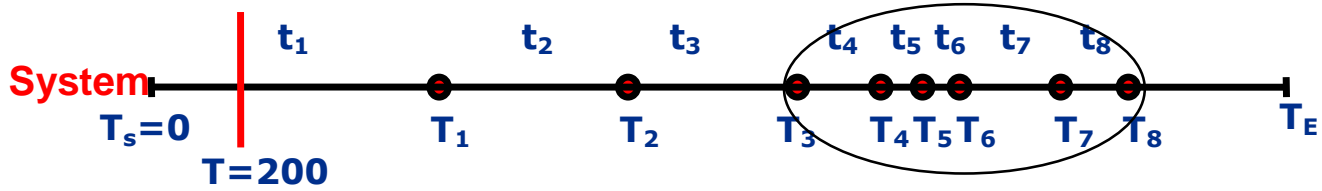

Therefore, it is concluded that with this model Reliability predictions are NOT valid. $^{2}$ However, the model can be used in order to predict Expected Number of Failures (ENOF) over time, as described in the next subsection.

\section{Results of the "MTBF" Model}

In the previous section we determined from the distribution of the TBFs that the MTBF is $324.5 \mathrm{Km}$. This estimate can be used to compute the expected Number of Failures over the Age of the System, or,

$$
E N O F=\frac{A g e}{M T B F}
$$

The following Table provides the estimated number of failures based on the above equation, at different system ages and based on the calculated MTBF of $324.5 \mathrm{Km}$. The estimate is compared to the Actual (True) number of failures which are determined from the original distributions and RBD.

Table 4: Expected Failures for Different System Ages, using MTBF

\begin{tabular}{|c|c|c|c|}
\hline Age $($ Km) & True & Age/mean & Percent Difference \\
\hline 250 & 0,053 & 0,77 & 1353,62 \\
\hline 500 & 0,32 & 1,54 & 381,51 \\
\hline 1500 & 3,22 & 4,62 & 43,56 \\
\hline 2000 & 4,8 & 6,16 & 28,40 \\
\hline 3000 & 8,2 & 9,24 & 12,74 \\
\hline
\end{tabular}

From Table 4 we can see that the difference between the estimate and the true value improves at higher ages. This is expected since "Averages" are more suited as system age approaches infinity.

\section{Using the Distribution of the System's Time-Between-Failures}

This approach is based on the approach used previously, with the exception of using the actual distribution of the TBFs instead of the MTBF. This can be simply done using BlockSim. A single block is created in BlockSim, with a failure

\footnotetext{
${ }^{2}$ If the Reliability at $200 \mathrm{Km}$ was sought, a distribution to the first failure event from each system could be used.
} 
distribution obtained from the TBFs. In this example, we obtained a Weibull distribution with beta $=1.11$, and eta $=337 \mathrm{Km}$ (see previous subsection). A Repair Distribution is also needed in BlockSim (since this is a repairable system), and since in this example we ignore the downtime, the Corrective Maintenance duration is set to Zero in BlockSim.

\section{Results of using the TBF Distribution}

Under these settings we run multiple BlockSim simulations for different system ages, and we record the results, in this case ENOF.

Table 5: Expected Failures for Different System Ages, using the TBF Distribution in BlockSim

\begin{tabular}{|c|c|c|c|}
\hline Age(Km) & True & TBF Distribution & Percent Difference \\
\hline 250 & 0,053 & 0,721 & 1260,38 \\
\hline 500 & 0,32 & 1,46 & 356,25 \\
\hline 1500 & 3,22 & 4,47 & 38,82 \\
\hline 2000 & 4,8 & 6,08 & 26,67 \\
\hline 3000 & 8,2 & 9,18 & 11,95 \\
\hline
\end{tabular}

It can be seen that little improvement is achieved using this approach. However, it is a useful approach in case we need to model large-scale systems, comprised of multiple repairable subsystems.

\section{Using Component Distributions and RBDs}

In this case we determine the individual failure distributions of the components from the data. This is done by obtaining the Time-Between-Failure of each individual component (e.g., time-between engine failures from each system). For example, for the engine, the following are the TBFs for each system:

System1
\begin{tabular}{|c|c|} 
Age=2500Km \\
\hline System Age & Component Age \\
\hline 249.8556746 & 249.8556746 \\
\hline 971.9650444 & 722.1093698 \\
\hline 2186.903602 & 1214.938558 \\
\hline & 313.096398 \\
\hline
\end{tabular}

\begin{tabular}{|c|c|}
\hline $\begin{array}{l}\text { ystem2 } \\
g e=1976 \mathrm{Km}\end{array}$ & \\
\hline System Age & Component Age \\
\hline 872.4111452 & 872.4111452 \\
\hline 1470.438019 & 598.0268738 \\
\hline & 505.561981 \\
\hline
\end{tabular}

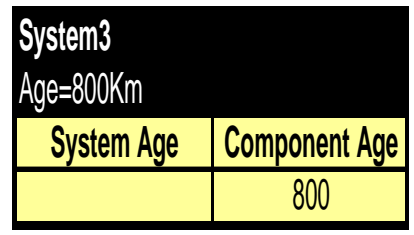

Based on this data, the failure distribution of the engine is determined: 
Different analysis procedures for computing the reliability of repairable systems Różne procedury analizy dla obliczania niezawodności systemów podlegajacych naprawie

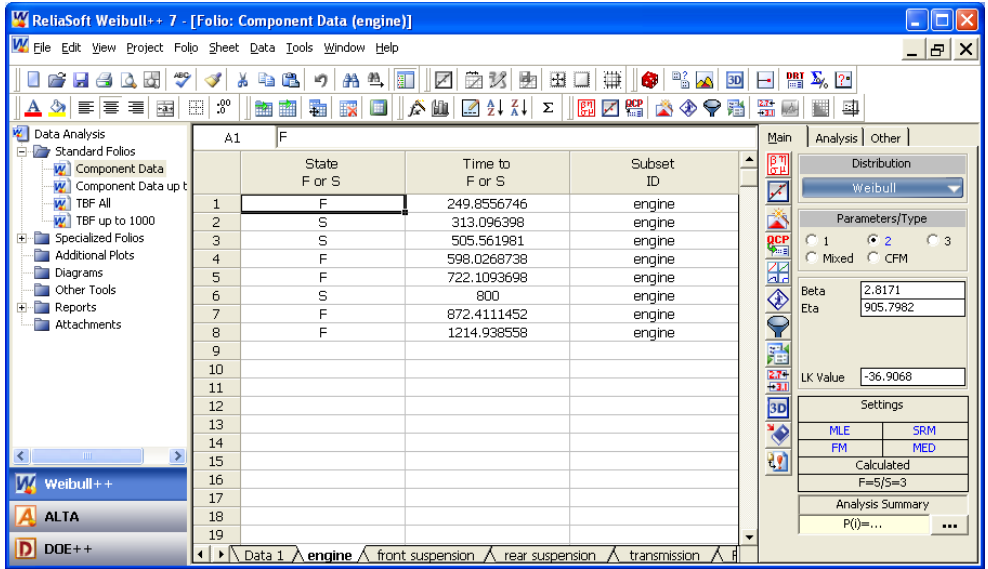

Similarly, the distributions of all the components can be determined, and are given in the following Table:

Table 6: Component Failure Distributions

\begin{tabular}{|c|c|c|c|}
\hline Component & Distribution & Parameter 1 & Parameter 2 \\
\hline Brakes Front $\mathrm{L}$ & WBL & 3.222573874 & 716.1151497 \\
\hline Brakes Front R & WBL & 3.222573874 & 716.1151497 \\
\hline Brakes Rear L & WBL & 15.36052078 & 391.4134836 \\
\hline Brakes Rear R & WBL & 15.36052078 & 391.4134836 \\
\hline Engine & WBL & 2.817058658 & 905.7981868 \\
\hline Front Suspension & LGN & 7.290293365 & 0.652096778 \\
\hline Rear Suspension & WBL & 2.457312008 & 1564.3648 \\
\hline Transmission & WBL & 3.142642565 & 1737.347234 \\
\hline
\end{tabular}

It should be noted that for the Brakes, all the Preventive Maintenance actions were considered as Suspensions when building the model. Also, the data from all the Rear Brakes were considered as one dataset (independent of the side), and similarly for the Front Brakes.

It can be seen that this method requires sufficient information (failures) at the component level. If component failures are scarce, then it will be difficult and possibly inaccurate to implement this method.

\section{Results of using Component Distributions}

These distributions were entered in BlockSim and simulations were performed for different system ages. A Preventive Maintenance Policy for the Brakes was included in the model as well. 
The results are given in the Table below:

Table 7: Expected Failures using Component Distribution in a RBD

\begin{tabular}{|c|c|c|c|}
\hline Age(Km) & True & RDB Analysis & Percent Difference \\
\hline 250 & 0,053 & 0,079 & 49,06 \\
\hline 500 & 0,32 & 0,366 & 14,38 \\
\hline 1500 & 3,22 & 3,29 & 2,17 \\
\hline 2000 & 4,8 & 5,2 & 8,33 \\
\hline 3000 & 8,2 & 8,44 & 2,93 \\
\hline
\end{tabular}

\section{Using the NHPP Model}

In this approach the individual cumulative times-to-event for each system are considered, and the NHPP model with a Power Intensity Function (aka Failure Rate) is fitted to the data. The model is given by the following Equation:

$$
\operatorname{Pr}[N(T)=n]=\frac{[\Lambda(T)]^{n} e^{-\Lambda(T)}}{n !}
$$

Where:

$$
\Lambda(T)=\lambda \cdot T^{\beta}
$$

and

$\operatorname{Pr}[N(t)=n]$ is the probability that $n$ failures will be observed by time, T.

$\Lambda(t)$ is the Failure Intensity Function (Rate of Occurrence of Failures, or failure rate).

This model is an extension of the Homogeneous Poisson Process, in which the failure rate is assumed to be constant (i.e. exponential distribution). In this case however, (NHPP), the failure rate could be increasing, decreasing or constant (as in the Weibull distribution), based on the value of beta in Eqn. (3). The assumption of this model is that after each failure, the system is restored to the same condition it was prior to the failure (aka As-Bad-As-Old). This assumption is sufficient when dealing with large systems; however, it becomes less applicable for smaller systems (less components) where a replacement has a significant impact on the system (renewal).

\section{NHPP Model Results}

The NHPP with a Power Law Intensity Function is fitted to the cumulative failure times (mileage in this example) of each system, using RGA:

The beta in this case is 1.65 , which indicates an increasing ROCOF for this system/design (i.e. wear-out). In other words, as the systems age, more events are observed and the TBF intervals decrease. 
Different analysis procedures for computing the reliability of repairable systems Różne procedury analizy dla obliczania niezawodności systemów podlegajacych naprawie

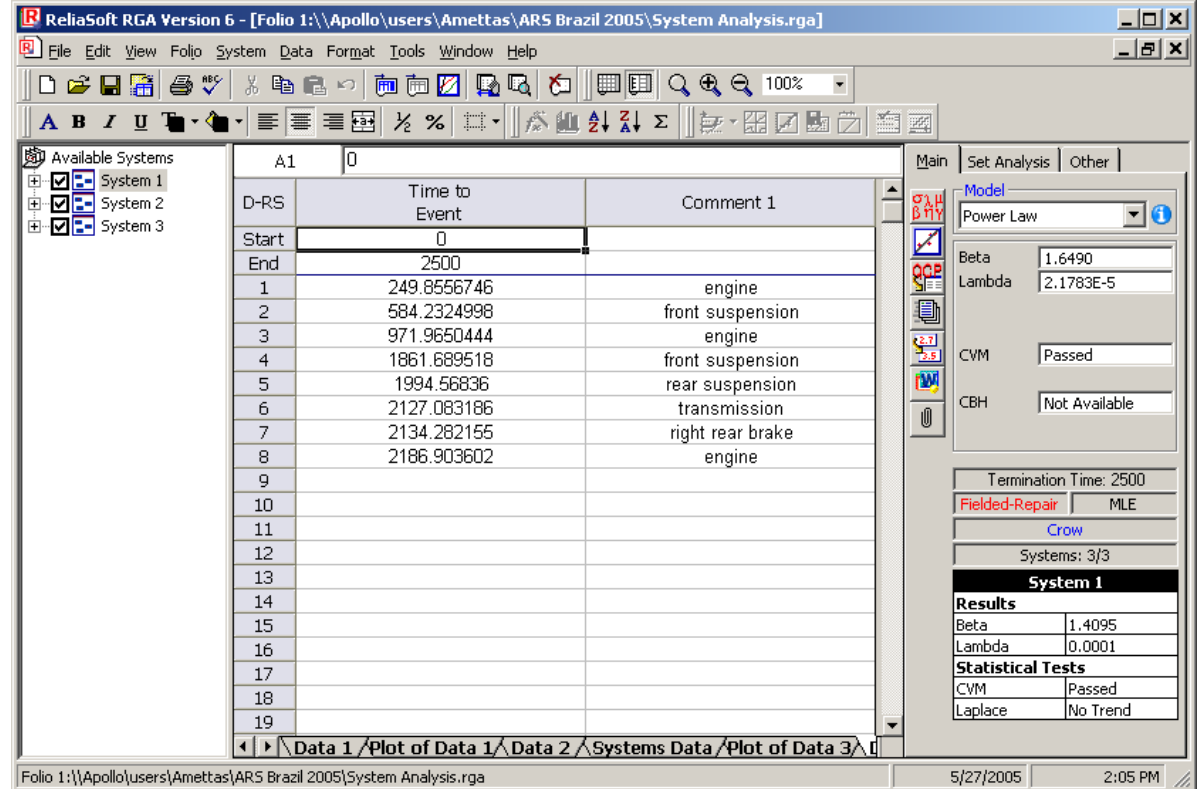

This is shown in the following plot:

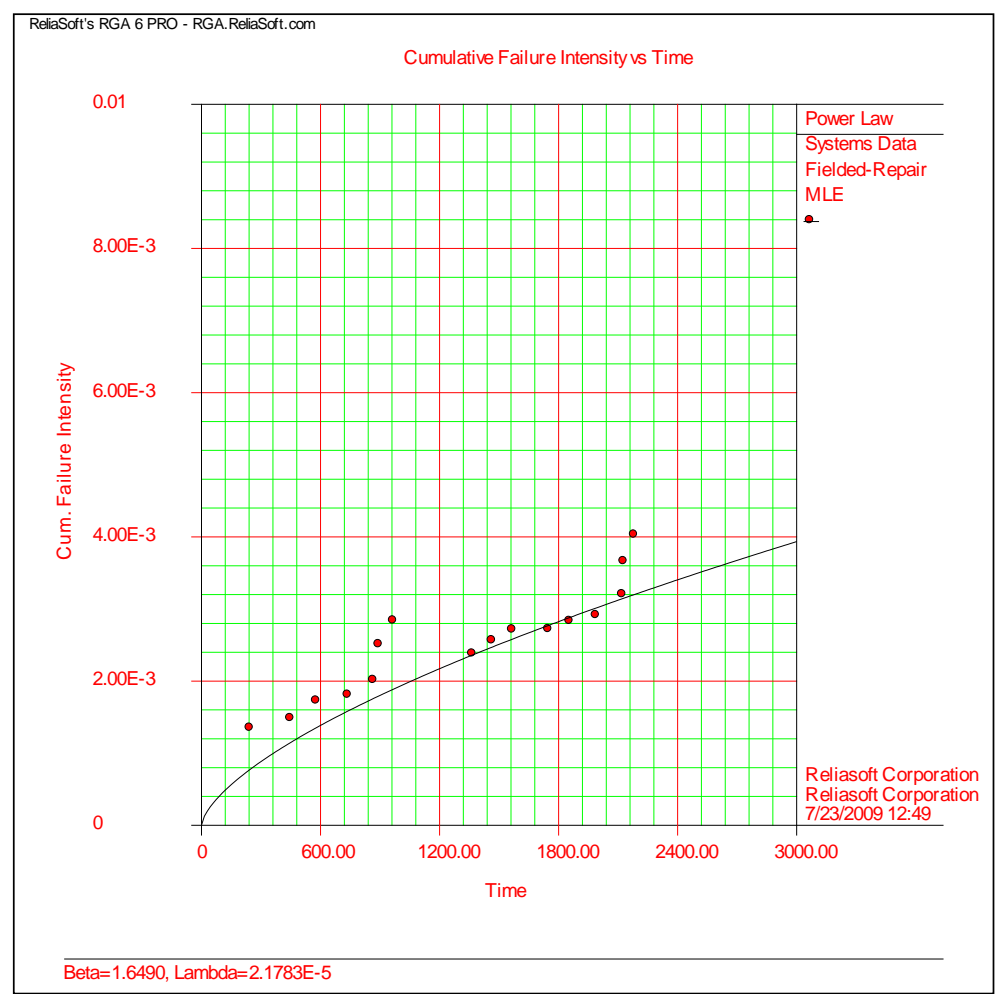


Based on the model, the Expected Number of Failures at different ages can be computed, as shown in the next plot:

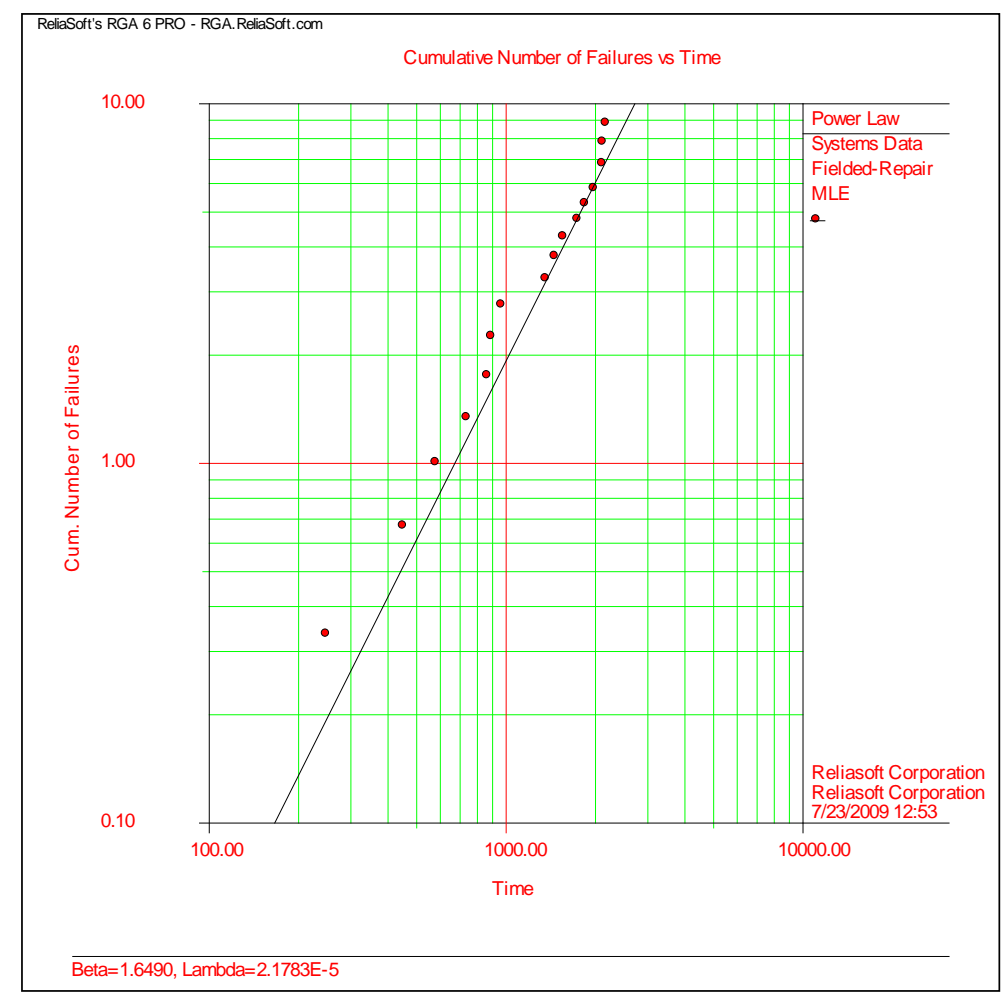

Selected results are given in the next Table:

Table 8: Expected Failure Results based on the NHPP model

\begin{tabular}{|c|c|c|c|}
\hline Age(Km) & True & NHPP & Percent Difference \\
\hline 250 & 0,053 & 0,196 & 269,81 \\
\hline 500 & 0,32 & 0,61 & 90,63 \\
\hline 1500 & 3,22 & 3,76 & 16,77 \\
\hline 2000 & 4,8 & 6,05 & 26,04 \\
\hline 3000 & 8,2 & 11,8 & 43,90 \\
\hline
\end{tabular}

\section{Using the GRP Model}

An improvement to the NHPP model is the GRP model. As mentioned in the subsection on the NHPP model, the model assumes that after each failure the system is As-Bad-As-Old (i.e. at the same condition as it was prior to the failure). The GRP (General Renewal Process) model relaxes this assumption, by including an additional parameter, $q$, which is a measure of the degree of restoration 
Different analysis procedures for computing the reliability of repairable systems Różne procedury analizy dla obliczania niezawodności systemów podlegajacych naprawie

(renewal), and it's determined from the data. The data used is the same as those used in the NHPP model, i.e., cumulative times-to-event of each system.

\section{GRP Model Results}

The GRP model is fitted to the data using Weibull++, as shown next:

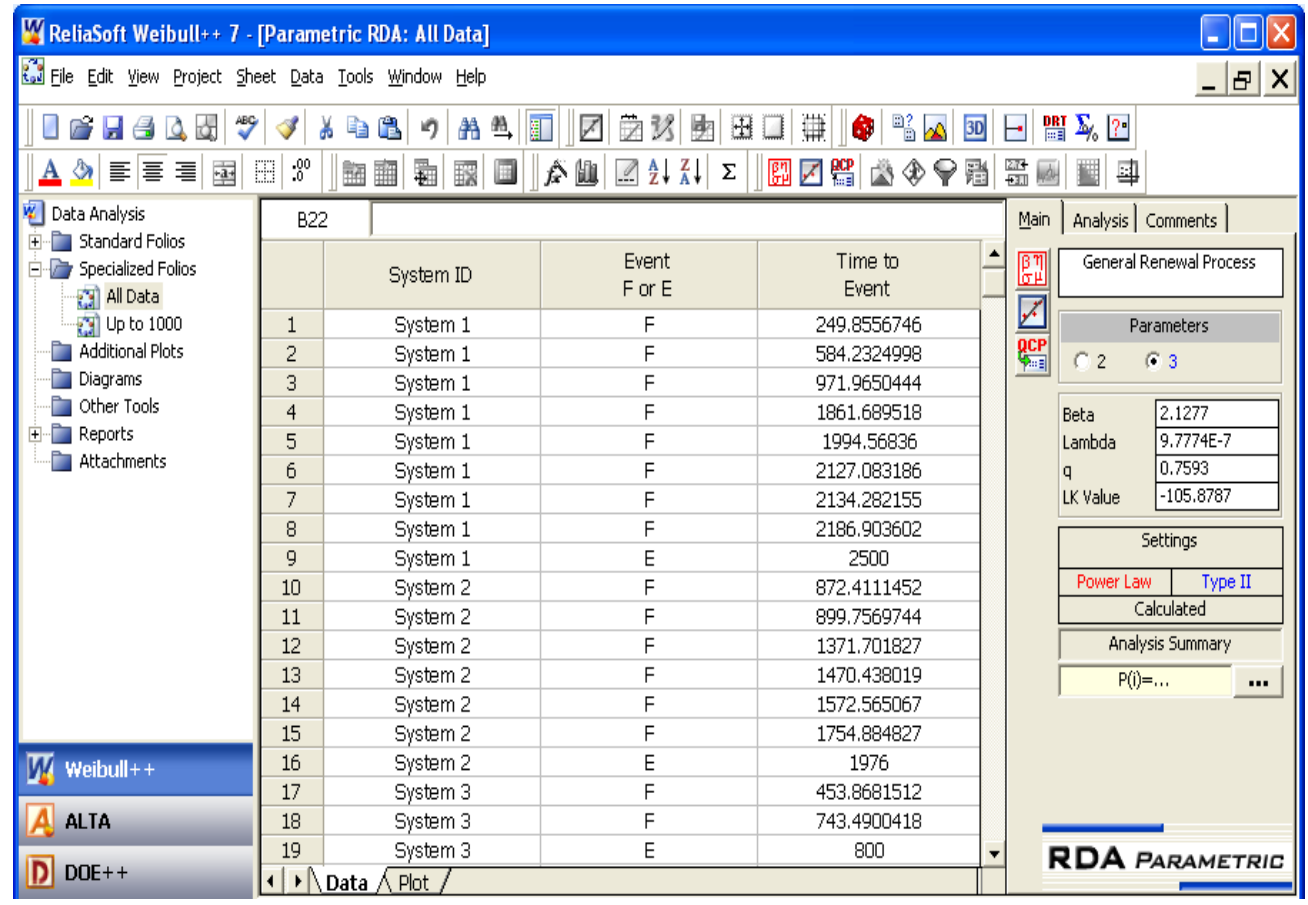

The ENOF results from this model and the corresponding difference from the true values are given in the next table:

Table 9: Expected Failures prediction based on the GRP Model

\begin{tabular}{|c|c|c|c|}
\hline Age(Km) & True & GRP & Percent Difference \\
\hline 250 & 0,053 & 0,128 & 141,51 \\
\hline 500 & 0,32 & 0,49 & 53,13 \\
\hline 1500 & 3,22 & 3,8 & 18,01 \\
\hline 2000 & 4,8 & 5,9 & 22,92 \\
\hline 3000 & 8,2 & 10,34 & 26,10 \\
\hline
\end{tabular}

\section{Conclusions}

Five different models were used to model the failure behavior of a repairable system. The data were generated using simulation, based on predefined failure distributions. The Expected Number of Failures was used as a metric for comparing to the true behavior of the system (which is known, since the generating 
failure distributions are known). The following Table and Plot compare the results of the five different methods:

\begin{tabular}{|c|c|c|c|c|c|c|}
\hline Age $($ Km) & True & Age/mean & TBF Distribution & RDB Analysis & NHPP & GRP \\
\hline 250 & 0,053 & 0,77 & 0,721 & 0,079 & 0,196 & 0,128 \\
\hline 500 & 0,32 & 1,54 & 1,46 & 0,366 & 0,61 & 0,49 \\
\hline 1500 & 3,22 & 4,62 & 4,47 & 3,29 & 3,76 & 3,8 \\
\hline 2000 & 4,8 & 6,16 & 6,08 & 5,2 & 6,05 & 5,9 \\
\hline 3000 & 8,2 & 9,24 & 9,18 & 8,44 & 11,8 & 10,34 \\
\hline
\end{tabular}

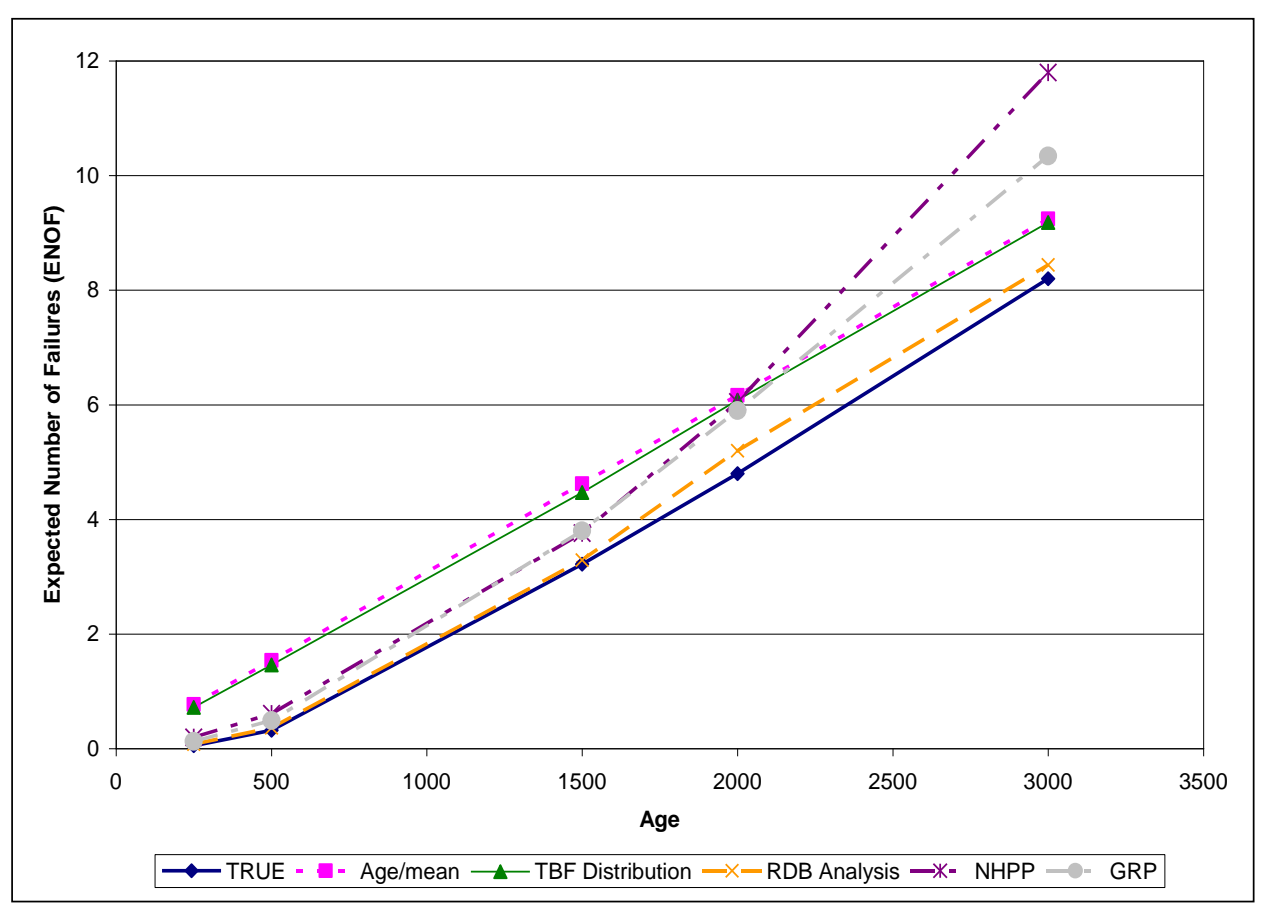

It can be seen that the RBD Simulation approach offers the more realistic estimates in this example. Of course the estimation always depends on the number of observed events, and this why the analysis method should be chosen based on the available information. If, for example, very few failure events have been observed, the RBD simulation approach based on component distributions, would be very hard to adopt, and most likely a bad estimator. The simulation using the system's TBF distribution could offer a better estimator when dealing with few failures at the component level, but it typically becomes a good predictor when extrapolating to longer system ages. In addition, this method cannot be used for Reliability/Unreliability calculations. The MTBF method is recommended only for quick, back of the envelope calculations, since the simulation based on the TBF distribution is similar and slightly more accurate. Finally, the GRP model is 
Different analysis procedures for computing the reliability of repairable systems Różne procedury analizy dla obliczania niezawodności systemów podlegajacych naprawie

typically more accurate than the NHPP model, but more complicated. Nevertheless, it is recommended over the NHPP model (the NHPP model is actually a special case of the GRP model).

Therefore, the following are recommended:

1) When sufficient data is available, the RBD simulation based on the component distributions method should be preferred.

2) The GRP and the simulation based on the system's TBFs distribution should be the next options. The choice between the two is dependent on the desired metrics to be computed. If for example Reliability calculations are required, then the TBF distribution method is not suitable. The advantage of the GRP model is that more metrics can be computed, as well as confidence bounds.

In addition to the above recommendations, this report can be used to further understand the assumptions behind each analysis, the required data needed, and the type of results that can be obtained. 


\title{
THE RELIABILITY TESTING OF BRICK INFRASTRUCTURE WITH OPERATING MODAL ANALYSIS
}

\section{BADANIE NIEZAWODNOŚCI INFRASTRUKTURY MUROWEJ Z UŻYCIEM OPERACYJNEJ ANALIZY MODALNEJ}

\author{
Mariusz Żóltowski \\ Uniwersytet Technologiczno-Przyrodniczy w Bydgoszczy \\ mazolto@utp.edu.pl
}

\begin{abstract}
Modal analysis is widely used in the removal of defects caused by vibration of infrastructure, structure modification, updating the analytical model, or the control of the state and is used to monitor the vibration of structures in the aerospace and civil engineering mechanics from early 1990 began to pay close attention to the use of operational modal analysis (OMA) in a study of the existing building structures. In this case, the vibration exciter platforms, buildings, towers, bridges, etc. to force Operating (ambient). Here we measure only the response of the force generated by the environment. OMA is also very attractive for aerospace and mechanical engineering. This article presents the results of the existing building structure (reinforced concrete wall using operational modal analysis software and used to carry out the LMS and visualization of the results of such research.
\end{abstract}

Keywords: operational modal analysis, the frequency of vibration, stability diagram

\begin{abstract}
Streszczenie: Analiza modalna jest szeroko stosowana $w$ usuwaniu usterek spowodowanych drganiami infrastruktury, modyfikacja struktury, aktualizacja modelu analitycznego, czy kontrola stanu, a także wykorzystywana jest do monitorowania wibracji struktur w przemyśle lotniczym i mechanice inżynierii ladowej Od poczatku 1990 zaczęto zwracać bacznq uwage na wykorzystywanie operacyjnej analizy modalnej (OMA) w badaniu istniejacych konstrukcji budowlanych. W tym przypadku wzbudnikiem drgań platformy, budynków, wież, mostów itp. jest wymuszenie eksploatacyjne (otoczenie). Mierzymy tu tylko odpowiedzi ukladu na wymuszenia generowane przez otoczenie. OMA jest również bardzo atrakcyjna dla przemystu lotniczego i inżynierii mechanicznej. $W$ tym artykule przedstawiono wyniki badań istniejacej konstrukcji budowlanej (ściana żelbetonowa) z zastosowaniem operacyjnej analizy modalnej i oprogramowaniem LMS shuzacym do przeprowadzenia i wizualizacji wyników takich badań.
\end{abstract}

Slowa kluczowe: operacyjna analiza modalna, częstość drgań, diagram stabilizacyjny 
The reliability testing of brick infrastructure with operating modal analysis Badanie niezawodności infrastruktury murowej z użyciem....

\section{Wprowadzenie}

Analiza modalna jest szeroko stosowana w usuwaniu usterek spowodowanych drganiami infrastruktury, modyfikacją struktury, aktualizacją modelu analitycznego, czy kontrolą stanu, a także wykorzystywana jest do monitorowania wibracji struktur w przemyśle lotniczym i mechanice inżynierii lądowej $[22,25,33]$. Tradycyjna eksperymentalna analiza modalna (EAM) korzysta $\mathrm{z}$ wejścia (wzbudzenie) i wyjścia (odpowiedź) i mierzy się ją w celu oszacowania parametrów modalnych, składających się $\mathrm{z}$ częstości modalnych, tłumienia i postaci drgań. Jednak tradycyjne EAM ma pewne ograniczenia, takie jak:

- w tradycyjnej EAM, sztuczne wzbudzenie jest normalnie przeprowadzone w celu pomiaru częstotliwości drgań;

- tradycyjna EAM jest zwykle prowadzona w środowisku laboratoryjnym, ale w wielu przypadkach prawdziwy stan degradacji może się znacznie różnić od tych badanych w środowisku laboratoryjnym.

Od początku 1990 zaczęto zwracać baczną uwagę na wykorzystywanie operacyjnej analizy modalnej (OMA) w badaniu istniejących konstrukcji budowlanych. W tym przypadku wzbudnikiem drgań platformy, budynków, wież, mostów itp. jest wymuszenie eksploatacyjne (otoczenie). Mierzymy tu tylko odpowiedzi układu na wymuszenia generowane przez otoczenie. OMA jest również bardzo atrakcyjna dla przemysłu lotniczego i inżynierii mechanicznej z powodu wielu zalet, takich jak:

- OMA jest tania i pozwala szybko i skutecznie prowadzić pomiary;

- brak problemu ze sztucznym wzbudzaniem drgań;

- można ocenić cechy dynamiczne całego, rzeczywiście istniejącego układu;

- towarzyszy jej nie skomplikowana w obsłudze aparatura pomiarowa;

- uzyskać można bardziej reprezentatywne wyniki badań niż w środowisku laboratoryjnym;

- dzięki szerokiemu pasmu losowego pobudzenia w warunkach normalnej eksploatacji, wyniki pomiarów są bardziej reprezentatywne.

W tym artykule przedstawiono wyniki badań istniejącej konstrukcji budowlanej (ściana żelbetonowa) $\mathrm{z}$ zastosowaniem operacyjnej analizy modalnej i oprogramowaniem LMS służącym do przeprowadzenia i wizualizacji wyników takich badań.

\section{Elementy dynamiki konstrukcji budowlanych}

Jednym z podstawowych kryteriów stosowanych w projektowaniu współczesnych konstrukcji budowlanych są własności dynamiczne konstrukcji. Mają one bezpośredni wpływ na drgania układu, emitowany hałas, wytrzymałość zmęczeniową i stabilność konstrukcji. Analizy własności dynamicznych w większości przypadków spotykanych w praktyce dokonuje się na podstawie analizy zachowania się modelu konstrukcji.

Jakość analizy zależy od wiarygodności modelu, mierzonej zgodnością zachowania obiektu i modelu poddanych zaburzeniom tego samego rodzaju. Model konstrukcji 
może być tworzony $\mathrm{w}$ procesie analitycznych przekształceń formalizmów stosowanych do opisu dynamiki układu bądź na podstawie wyników eksperymentów wykonywanych na rzeczywistym obiekcie [22,23,25,33].

Najczęściej do opisu dynamiki konstrukcji stosuje się modele strukturalne (MES), które buduje się zgodnie z zasadami metody elementów skończonych. Metoda ta polega na dyskretyzacji układu o ciagłym rozkładzie parametrów, przy przyjęciu pewnych założeń upraszczających, np. związanych z linią ugięcia modelowanego elementu (metoda przemieszczeń). Jednak zbudowane w ten sposób modele, w szczególności do celów analizy dynamiki, dają wyniki przybliżone, których zastosowanie jest bardzo ograniczone. Wymagają one dostrajania na podstawie znajomości własności zmierzonych na rzeczywistym obiekcie.

Model strukturalny można wykorzystać do wyznaczania modeli innego rodzaju, np. modelu modalnego będącego zbiorem częstości drgań własnych, odpowiadającym im współczynników tłumienia i postaci drgań - przez zastosowanie odpowiedniej transformacji współrzędnych modelu. Model taki umożliwia przewidywanie zachowania się modelowanej konstrukcji przy dowolnym wymuszeniu. Model modalny może być zidentyfikowany na rzeczywistym obiekcie na podstawie wyników eksperymentu identyfikacyjnego. Jest to jeden $\mathrm{z}$ najczęściej identyfikowanych modeli rzeczywistych konstrukcji budowlanych, stosowany z wykorzystaniem drgań [3].

Wykorzystanie drgań w badaniu degradacji (jakości) konstrukcji budowlanych wynika z następujących powodów:

- procesy drganiowe są odzwierciedleniem zjawisk fizycznych zachodzących w konstrukcjach (odkształcenia, naprężenia, pęknięcia), od których zależy stopień destrukcji (zdatność) i poprawne funkcjonowanie, co wynika $\mathrm{z}$ charakteru rozprzestrzeniania się procesu drganiowego;

- łatwość pomiaru procesów drganiowych w warunkach normalnej eksploatacji obiektu, bez konieczności wyłączania go z ruchu oraz specjalnego przygotowania, umożliwia bezdemontażową ocenę stanu destrukcji;

- procesy drganiowe cechują się dużą prędkością przekazywania informacji w jednostce czasu, określoną wzorem Shanon'a:

$$
C=F \lg _{2}\left(1+\frac{N_{S}}{N_{Z}}\right)
$$

zależną od szerokości widmowej procesu $F$ oraz stosunku mocy sygnału użytecznego $N \mathrm{~S}$ do mocy szumów zakłócających $N Z$;

- procesy drganiowe cechują się złożoną strukturą czasową, amplitudową i częstotliwościową, co zapewnia przy właściwym ich przetwarzaniu ocenę stanu całej konstrukcji, jak również pojedynczych jej elementów.

Podczas eksploatacji konstrukcji, na skutek istnienia szeregu czynników zewnętrznych (wymuszenia środowiska, wymuszeń od innych konstrukcji) oraz wewnętrznych (starzenie, zużycia, współpraca elementów) w konstrukcji następują zaburzenia stanów równowagi, które rozchodzą się $\mathrm{w}$ ośrodku 
The reliability testing of brick infrastructure with operating modal analysis Badanie niezawodności infrastruktury murowej z użyciem....

sprężystym - materiale, z którego zbudowana jest konstrukcja (rys.1). Zaburzenia mają charakter dynamiczny i zachowują warunki równowagi pomiędzy stanem bezwładności, sprężystości, tłumienia i wymuszenia. Powoduje to w konsekwencji rozpraszanie energii fal, ich ugięcia, odbicia i wzajemne nakładanie się. Istnienie źródeł i rozprzestrzenianie się zaburzeń powoduje występowanie drgań elementów konstrukcji i otaczającego je środowiska.

Wyodrębniając $\mathrm{w}$ analizie stanu dynamicznego konstrukcji procesy wejściowe, strukturę i procesy wyjściowe, należy pamiętać o ich losowym charakterze.

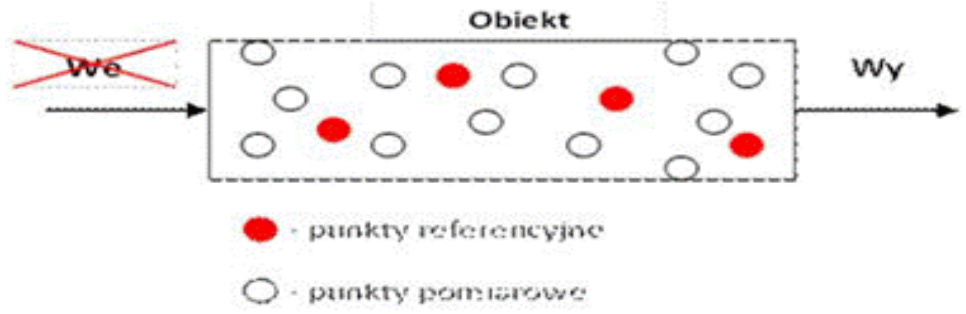

Rys.1 Istota pomiarowa w eksploatacyjnej analizie modalnej

Wejście wewnętrzne, traktowane jako zbiór wielkości wymuszających określających strukturę konstrukcji (kształt, jakość wykonania, luzy itd.) i sposób współpracy elementów jest kształtowane w warunkach losowych podczas wytwarzania, co ujawnia się własnościami losowymi podczas funkcjonowania.

Wejście zewnętrzne, określające warunki współpracy elementów konstrukcji z innymi elementami systemu (zmiany obciążeń, prędkości, wpływ środowiska) ma w praktyce również charakter losowy.

Bogactwo możliwości zaistnienia losowości i istnienia zakłóceń jest przyczyną dodatkowych założeń dotyczących wejść oraz zachodzących transformacji stanów destrukcji konstrukcji. Dotyczą one założeń o liniowości, stacjonarności i ergodyczności modeli obiektów i procesów [22,33].

\section{3. Środowisko eksperymentalnej analizy modalnej}

Analiza modalna jest powszechnie stosowana do badania własności dynamicznych różnorodnych konstrukcji. Badania modalne przeprowadza się dla miniaturowych i precyzyjnych konstrukcji, jak np. dyski optyczne [8], a także dla dużych konstrukcji budowlanych, jak zapory wodne czy mosty [22]. W wyniku analizy modalnej otrzymuje się model modalny konstrukcji, który może być zastosowany do rozwiązywania wielu inżynierskich problemów związanych z syntezą układów, analizą zachowania się konstrukcji pod wpływem różnych wymuszeń, modyfikacją własności dynamicznych, syntezą układów sterowania itp.

Jednym z podstawowych problemów, które mogą być efektywnie rozwiązane za pomocą analizy modalnej jest optymalizacja własności dynamicznych konstrukcji budowlanych, rozumiana jako modyfikacja konstrukcji w celu minimalizacji rozprzestrzeniania się w niej drgań. Techniki tutaj stosowane są nazywane metodami 
modyfikacji strukturalnej konstrukcji. Metody te wywodzą się wprost z metody elementów skończonych i są oparte na aparacie matematycznym umożliwiającym badanie wrażliwości zachowania się modeli na zmiany ich parametrów modalnych.

Przedstawione poniżej informacje stanowią podstawy analizy modalnej, która w krajach o wysoko rozwiniętej technologii jest powszechnie stosowana w praktyce jako narzędzie wspomagania procesu projektowania obiektów (zamiennie do MES), w których istotnym wskaźnikiem jakości konstrukcji jest jej zachowanie w warunkach dynamicznych.

Jak już wspomniano układ o jednym stopniu swobody jest najprostszym modelem fizycznym reprezentującym całą klasę obiektów rzeczywistych określonych następującymi parametrami: masą - $\mathrm{m}$, stałą sprężystości - $\mathrm{k}$, współczynnikiem tłumienia - c, i siłą wymuszająca - F. Po wykorzystaniu wprowadzonych parametrów i zasad opisu modelu (rys.2) otrzymano równanie różniczkowe ruchu drgającego układu o jednym stopniu swobody, wyrażone zależnością:

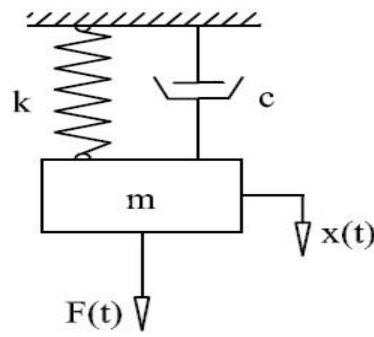

Rys.2 Uktad o jednym stopniu swobody dla ruchu translacyjnego

$$
m \ddot{x}+c \dot{x}+k x=F(t)
$$

gdzie: $\ddot{\mathrm{x}}, \dot{\mathrm{x}}, \mathrm{X}$ - wektory przyśpieszeń, prędkości i przemieszczeń.

W praktyce większość rodzajów tłumienia występującego w układach można zastąpić równoważnym tłumieniem wiskotycznym. Zakładając zerowe warunki początkowe: $[\mathrm{x}(0)=0), \dot{\mathrm{x}}(0)=0)]$ oraz wykorzystując twierdzenie Laplace'a równanie (2) można przekształcić do postaci [22,25]:

$$
\left(\mathrm{ms}^{2}+\mathrm{cs}+\mathrm{k}\right) \mathrm{X}(\mathrm{s})=\mathrm{F}(\mathrm{s})
$$

gdzie: $\mathrm{s}-\mathrm{zmienna}$ zespolona, $\mathrm{s}=\mathrm{j} \omega$.

Równanie można zapisać w formie uproszczonej:

$$
\mathrm{Z}(\mathrm{s}) \mathrm{X}(\mathrm{s})=\mathrm{F}(\mathrm{s})
$$

Wielkość Z(s) jest nazywana sztywnościq dynamiczna: 
The reliability testing of brick infrastructure with operating modal analysis Badanie niezawodności infrastruktury murowej z użyciem....

$$
\mathrm{Z}(\mathrm{s})=\frac{\mathrm{F}(\mathrm{s})}{\mathrm{X}(\mathrm{s})}
$$

W praktycznych zastosowaniach analizy układów stosuje się odwrotność sztywności dynamicznej H(s) zwaną podatnościq dynamicznq:

$$
H(s)=\frac{X(s)}{F(s)}
$$

Podatność dynamiczną układu o jednym stopniu swobody w oparciu o równanie można zapisać jako funkcję poszczególnych parametrów układu:

$$
\mathrm{H}(\mathrm{s})=\frac{\frac{1}{\mathrm{~m}}}{\mathrm{~s}^{2}+\frac{\mathrm{c}}{\mathrm{m}} \mathrm{s}+\frac{\mathrm{k}}{\mathrm{m}}}
$$

Pojęciami ściśle związanymi z analizą modalną są bieguny układu; zawierają one w sobie dwa składniki: częstości własne i współczynniki tłumienia. Mianownik $\mathrm{z}$ zależności nazywany jest równaniem charakterystycznym. Bieguny układu sa definiowane jako pierwiastki równania charakterystycznego i dla równania maja one postać:

$$
\lambda_{1,2}=-\frac{c}{2 m} \pm \sqrt{\left(\frac{c}{2 m}\right)^{2}-\frac{k}{m}}
$$

Na podstawie równania można zdefiniować szereg często stosowanych $\mathrm{w}$ analizie modalnej pojęć. Wśród nich wyróżnia się pojęcie częstości własnej niettumionej $($ dla $\mathrm{c}=0)$ opisane zależnością:

$$
\varpi=\sqrt{\frac{k}{m}}
$$

W teorii drgań układów mechanicznych rozróżnia się trzy przypadki ruchu układów o jednym stopniu swobody: tłumienie krytyczne, nadkrytyczne i podkrytyczne. Występowanie jednego z tych przypadków zależy od wartości wyróżnika $\Delta$ dla równania charakterystycznego. Jeśli $\Delta=0$, to rozpatrujemy układ $\mathrm{z}$ thumieniem krytycznym, które objawia się jedną oscylacją w ruchu swobodnym. $\mathrm{Z}$ warunku $\Delta=0$ wyznacza się wspótczynnik ttumienia krytycznego $c_{k}$ :

$$
\mathrm{c}_{\mathrm{k}}=2 \mathrm{~m} \sqrt{\frac{\mathrm{k}}{\mathrm{m}}}
$$

W analizie modalnej do oceny wielkości tłumienia w układzie stosuje się bezwymiarowy współczynnik thumienia $\xi$ wyrażony zależnością (11). Bardzo często wartość bezwymiarowego współczynnika tłumienia podaje się w procentach. 


$$
\xi=\frac{\mathrm{c}}{\mathrm{c}_{\mathrm{k}}}
$$

Jeżeli $\Delta>0$, thumienie w układzie jest nadkrytyczne i ruch swobodny odbywa się bez oscylacji. Współczynnik $\xi$ w tym przypadku posiada wartość większą od 1.

Jeżeli $\Delta<0$, tłumienie w układzie jest podkrytyczne i ruch swobodny ma charakter oscylacyjny. Współczynnik $\xi$ w tym przypadku nie przekracza wartości 0,1 .

Rozwiązanie równania ruchu dla przypadku ruchu swobodnego przyjmuje postać:

$$
x(t)=x_{1} e^{\lambda_{1} t}+x_{2} e^{\lambda_{2} t}
$$

gdzie: $\lambda_{1}, \lambda_{2}-$ pierwiastki równania charakterystycznego.

$\mathrm{W}$ przypadku tłumienia podkrytycznego pierwiastki te są zespolone i mają następujące postacie:

$$
\begin{aligned}
& \lambda_{1}=\delta_{1}+j \omega_{1} \\
& \lambda_{2}=\delta_{2}+j \omega_{2}
\end{aligned}
$$

gdzie: $\delta_{1}-$ współczynnik tłumienia odniesiony do częstości drgań własnych nietłumionych, $\omega_{1}-$ częstość drgań własnych nietłumionych.

Wprowadzając do zależności uprzednio zdefiniowane wielkości otrzymuje się:

$$
\lambda_{1}=\left(-\xi_{1}+j \sqrt{1-\xi_{1}^{2}}\right) \Omega_{1}
$$

Bezwymiarowy współczynnik tłumienia wyraża zależność:

$$
\xi_{1}=\frac{\delta_{1}}{\sqrt{\omega_{1}^{2}+\delta_{1}^{2}}}
$$

Związek pomiędzy współczynnikiem thumienia $\delta_{1}$ a bezwymiarowym współczynnikiem tłumienia $\xi_{1}$ wyrażony został w poniższej postaci:

$$
\delta_{1}=-\xi_{1} \Omega_{1}
$$

Częstość drgań własnych nietłumionych wyraża się zależnością [22]:

$$
\Omega_{1}=\sqrt{\omega_{1}^{2}+\delta_{1}^{2}}
$$

Bardzo często $\mathrm{w}$ analizie modalnej stosuje się pojęcie reszty modalnej. W celu jej zdefiniowania należy przekształcić równanie i zapisać w postaci iloczynowej:

$$
H(s)=\frac{\frac{1}{m}}{\left(s-\lambda_{1}\right)\left(s-\lambda_{1}^{*}\right)}
$$


The reliability testing of brick infrastructure with operating modal analysis Badanie niezawodności infrastruktury murowej z użyciem....

Po dokonaniu rozkładu na ułamki proste zależności otrzymuje się równanie:

$$
\mathrm{H}(\mathrm{s})=\frac{\mathrm{A}_{1}}{\left(\mathrm{~s}-\lambda_{1}\right)}+\frac{\mathrm{A}_{1}^{*}}{\left(\mathrm{~s}-\lambda_{1}^{*}\right)}
$$

gdzie: $\mathrm{A}_{1}$ - reszta modalna określona wzorem:

$$
A_{1}=\frac{\frac{1}{m}}{2 j \omega_{1}}
$$

Analogicznie wyznacz się te wielkości dla układów o wielu stopniach swobody.

W zastosowaniu klasycznej analizy modalnej do identyfikacji parametrów modalnych badanego obiektu w trakcie badań wyznacza się parametry modalne na podstawie pomiaru charakterystyk częstościowych zmierzonych na obiekcie w trakcie eksperymentu, polegającego na sterowanym wymuszeniu drgań układu i pomiarze odpowiedzi $\mathrm{w}$ postaci widma przyśpieszenia drgań. Na podstawie znajomości wymuszenia i widma odpowiedzi dokonuje się identyfikacji przebiegu charakterystyk częstościowych badanego układu. Przy pomocy takich metod realizowanych $\mathrm{w}$ dziedzinie częstości, jesteśmy w stanie wyznaczyć parametry modalne układu $\mathrm{w}$ otoczeniu pojedynczej częstości własnej lub w wybranym paśmie częstości zawierającym więcej jak jedną częstość własną. Dla wielu konstrukcji w warunkach eksploatacji działają na układ zupełnie inne siły wymuszające, które co do charakteru przebiegu czasowego, rozkładu przestrzennego i amplitudy nie mogą być realizowane $\mathrm{w}$ warunkach laboratoryjnych. Podobnie dla warunków brzegowych, które w trakcie eksperymentu zależą od możliwości zamocowania obiektu na stanowisku badawczym, różnią się one od warunków występujących w czasie eksploatacji.

W praktycznych zastosowaniach realizacji badań modalnych obiektów, badany układ jest zbyt duży i posiada zbyt dużą masę, aby można było wymusić odpowiednią amplitudę ruchu w warunkach eksperymentu czynnego. Wymienione ograniczenia są minimalizowane poprzez zastosowanie metod analizy modalnej realizowanej na podstawie pomiarów przeprowadzonych w trakcie normalnej pracy obiektu.

Parametry modelu modalnego umożliwiają rozprzężenie równań opisujących drgania układu, a ich wartości wyznacza się z zależności [22,25,33]:

$$
m_{r}=\frac{1}{2 j \varpi_{r} R_{i r}} ; \quad k_{r}=\varpi_{n r}^{2} m_{r} ; c_{r}=2 m_{r} \varpi_{r n} \delta_{m}
$$

Wielkości te opisują własności układu związane z $r$ - tą częstością własną i zmiany częstości własnej zależą wprost proporcjonalnie od wielkości zmian sztywności lub masy, jak też zależą od miejsca rozwoju uszkodzenia w konstrukcji.

Przedstawione uzasadnienie wystarcza dla opisu zmian destrukcji elementów murowych, natomiast cała teoria $\mathrm{z}$ obszaru analizy modalnej opisana została w dostępnej literaturze $[22,25]$. 
Zastosowanie najnowocześniejszych technologii informatycznych w analizie modalnej powoduje, że otrzymane modele modalne stają się bardziej wiarygodne i moga być wykorzystywane do rozwiązywania wielu problemów związanych z konstruowaniem złożonych obiektów budowlanych o zadanych własnościach dynamicznych.

Analiza modalna jest stosowana dla celów modyfikacji konstrukcji, diagnostyki stanu konstrukcji, dla celów syntezy sterowania w układach aktywnej redukcji drgań oraz dla celów weryfikacji i walidacji modeli numerycznych, takich jak modele elementów skończonych czy elementów brzegowych.

Analiza modalna może być stosowana, jeżeli spełnione są następujące założenia:

- układ jest liniowy i jego dynamika może być opisana za pomocą liniowego układu równań różniczkowych zwyczajnych lub cząstkowych;

- współczynniki równań opisujących dynamikę obiektu są stałe w czasie pomiarów;

- układ jest obserwowalny i istnieje możliwość pomiaru wszystkich charakterystyk, których znajomość jest niezbędna do identyfikacji modelu;

- badany układ spełnia zasadę wzajemności Maxwella;

- thumienie w układzie jest małe lub proporcjonalne.

Ważnym ograniczeniem stosowania analizy modalnej jest też założenie o ograniczonej liczbie stopni swobody badanego układu, z czym wiąże się wymiar macierzy mas, sztywności i thumienia oraz liczba teoretycznych częstości własnych i postaci drgań.

Przy spełnieniu powyższych założeń analizę modalną można określić jako transformację (przekształcenie) złożonego układu, którego dynamika jest opisana za pomocą układu równań różniczkowych, na zbiór układów o jednym stopniu swobody opisanych za pomocą niezależnych równań różniczkowych drugiego rzędu - rys.3.

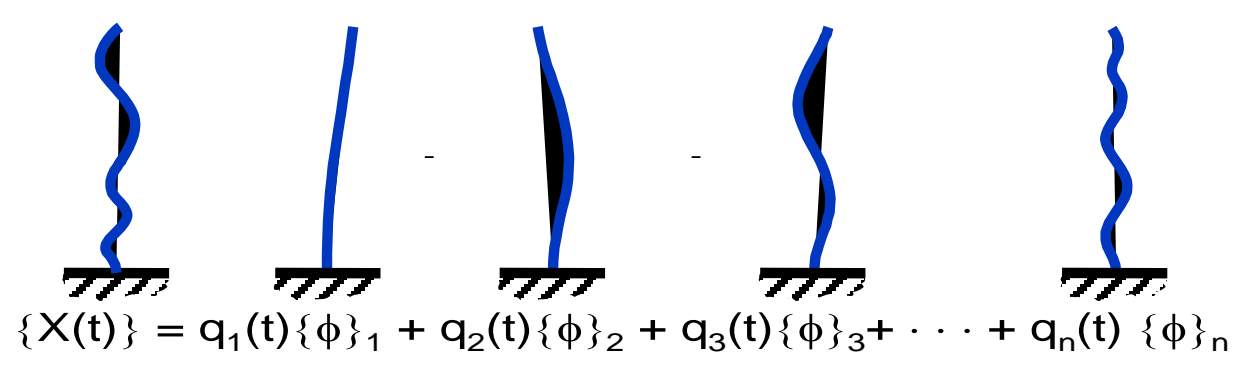

\section{Rys.3. Rozkład drgań złożonych na drgania proste}

Matematycznie, zadanie to można zdefiniować jako rozprzęganie równań różniczkowych zwyczajnych, opisujących dynamikę badanej konstrukcji.

Eksploatacyjna analiza modalna wykorzystywana jest do identyfikacji obiektów o dużych rozmiarach przestrzennych i dużych masach, oparta jest o pomiar odpowiedzi na wymuszenia eksploatacyjne, będące wynikiem działania sił 
The reliability testing of brick infrastructure with operating modal analysis

Badanie niezawodności infrastruktury murowej z użyciem....

zewnętrznych, bądź wymuszeń kinematycznych oraz procesu destrukcji elementów budowli $[5,7,9,33]$.

Eksploatacyjna analiza modalna:

- umożliwia analizę modalną obiektów o dużych rozmiarach, dla których testy laboratoryjne byłyby utrudnione,

- modeluje poprawniej obiekty, gdyż wymuszenia odpowiadają obciążeniom rzeczywistym,

- umożliwia identyfikację modeli nieliniowych.

Metoda eksploatacyjnej analizy wyznaczania postaci drgań oparta jest o wielokanałowy pomiar odpowiedzi w węzłowych punktach obiektu rzeczywistego. System umożliwia graficzne przedstawienie zachowań dynamicznych obiektu w warunkach eksploatacyjnych. Danymi wejściowymi do systemu są przebiegi czasowe drgań mechanicznych, występujących w węzłowych punktach obiektu, odniesione do jednego z nich (o najwyższej amplitudzie). Wyznaczane są widma mocy własne $G_{x x}(j, \varpi)$ i widma mocy wzajemne odpowiedzi $G_{y y}(j, \varpi)$, przy czym punkt "x" obiektu jest punktem odniesienia, a punkty "y" są węzłowymi punktami obiektu.

Obecnie coraz częściej stosuje się modele modalne do oceny stanu destrukcji materiałów budowlanych konstrukcji. Ideą tej metody jest śledzenie zmian parametrów modelu (w tym przypadku modelu modalnego), powstających na skutek zużycia lub awarii, na podstawie bieżących obserwacji obiektu. W metodzie tej tworzy się model modalny dla obiektu bez uszkodzenia, jako wzorzec, a następnie w czasie eksploatacji identyfikuje się model modalny i bada jego korelację z modelem dla obiektu nieuszkodzonego. W przypadku, gdy korelacja taka występuje, można twierdzić, że obiekt jest w stanie bez uszkodzenia. W przypadku braku korelacji można spodziewać się uszkodzenia obiektu. Dysponując informacjami o wpływie danego uszkodzenia na parametry modelu modalnego, można określić jego rodzaj oraz ocenić ilościowo stopień uszkodzenia.

Przedstawione zastosowania analizy modalnej do rozwiązywania zagadnień badawczych i inżynierskich wskazują na uniwersalność i efektywność tej metody, która jak do tej pory nie znała szerszego zastosowania $\mathrm{w}$ praktyce polskich biur projektowych, czy jednostek badawczych. Na świecie w większości krajów o rozwiniętej technologii stanowi ona podstawowe narzędzie syntezy i analizy dynamicznej konstrukcji.

\section{Eksperyment w analizie modalnej}

Eksperyment w identyfikacji stanu destrukcji badanych elementów murowych jest podstawowym źródłem informacji i na jego podstawie ustala się wartości miar i strukturę modelu. $Z$ jednej strony od jakości wyników badań eksperymentalnych zależy jakość otrzymanego modelu, z drugiej zaś sposób przeprowadzenia 
eksperymentu determinuje strukturę, identyfikowanego modelu. Eksperyment w analizie modalnej można podzielić na następujące etapy:

1) Planowanie eksperymentu:

- wybór sposobu wymuszania drgań badanych elementów i punktów przyłożenia,

- wybór punktów pomiaru drgań i aparatury pomiarowej,

- wybór odpowiedniego sprzętu pomiarowego,

- wybór sposobu zawieszenia układu.

2) Kalibracja toru pomiarowego.

3) Akwizycja i przetwarzanie wyników eksperymentu.

Celem eksperymentu $\mathrm{w}$ analizie modalnej jest wymuszenie ruchu badanego elementu murowego oraz pomiar odpowiedzi na zadane wymuszenie. Na podstawie zmierzonych wielkości procesu drganiowego dokonywana jest estymacja jego charakterystyk dynamicznych. Ogólną procedurę realizacji badań tej pracy pokazano na rys.4.

\section{TEST MODALNY}

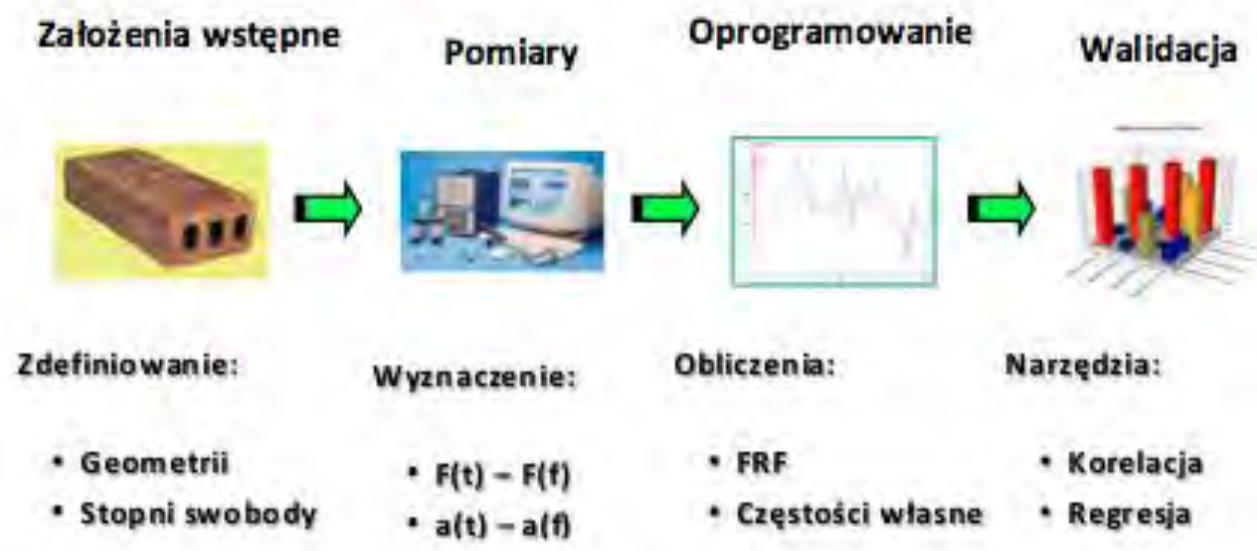

Rys.4. Przebieg procedury realizacji badań w analizie modalnej

Badany element murowy poddany wymuszeniu siłowemu odpowiada sygnałem drganiowym, proporcjonalnym do stanu destrukcji. Sygnał wymuszenia i odpowiedzi wykorzystuje się dalej do wyznaczenia funkcji $F R F$ i diagramu stabilizacyjnego, a w nim częstości drgań własnych. Przy okazji realizacji tych procedur są dostępne inne ciekawe poznawczo estymatory procesów drganiowych, które także wykorzystuje się $\mathrm{w}$ dalszych badaniach. Wyniki badań po przetworzeniu według różnych algorytmów poddaje się opracowaniu statystycznemu. 
The reliability testing of brick infrastructure with operating modal analysis

Badanie niezawodności infrastruktury murowej z użyciem....

Typowy zestaw aparatury do realizacji eksperymentu w analizie modalnej składa się z następujących elementów:

- układu pomiaru wymuszenia ruchu i pomiaru odpowiedzi,

- układu kondycjonowania sygnałów (wstępnego przetwarzania),

- układu przetwarzania i zbierania sygnałów,

- układu generowania sygnału wymuszającego,

- układu wzbudzania drgań.

Najprostszym ze względu na obsługę rozwiązaniem jest zastosowanie analizatora sygnałów, natomiast najnowocześniejszym, dającym największe możliwości jest rozwiązanie oparte na stacji roboczej i specjalizowanym interfejsie pomiarowym. Podstawową operacją wykonywaną przez wszystkie stosowane $\mathrm{W}$ analizie modalnej przyrządy pomiarowe jest przetwarzanie analogowo-cyfrowe, które umożliwia stosowanie technik cyfrowego przetwarzania sygnałów do wyznaczenia wymaganych przez analizę modalną estymatorów charakterystyk.

$\mathrm{W}$ badaniach modalnych jest obojętne, którą $\mathrm{z}$ wielkości kinematycznych ruchu mierzymy jako odpowiedź układu. W praktyce jednak pomiary przemieszczenia dają lepsze rezultaty $\mathrm{w}$ zakresie niskich częstości, a przyśpieszenia $\mathrm{w}$ zakresie częstości wysokich. Powszechnie uważa się, że pomiary prędkości są najbardziej optymalne $\mathrm{w}$ badaniach dynamiki konstrukcji ze względu na to, że wartość skuteczna prędkości drgań jest w pewnym sensie miarą energii kinetycznej drgań układu. Jednak czujniki do pomiaru przemieszczeń i prędkości są stosunkowo ciężkie i mogą wpływać na zachowanie się badanego obiektu.

Czujniki przyspieszeń mają znacznie mniejszą masę i dzięki temu nie wpływają na ruch układu. Dodatkową zaletą zastosowania czujnika przyśpieszeń jest fakt, że z sygnału przyspieszenia przez całkowanie można otrzymać sygnał prędkości lub przemieszczenia drgań. Operacja $\mathrm{w}$ drugą stronę, polegająca na różniczkowaniu, może prowadzić do dużych błędów, szczególnie w zakresie wyższych częstości. Z powyższych względów czujniki przyspieszeń są najczęściej stosowanymi przetwornikami do realizacji badań modalnych konstrukcji. Czujniki przyspieszeń zbudowane na bazie zjawiska piezoelektrycznego można zamodelować jako układ $\mathrm{o}$ jednym stopniu swobody $\mathrm{z}$ thumieniem. Masa $\mathrm{w}$ tym modelu jest masa sejsmiczną obciążająca kryształ materiału piezoelektrycznego w czasie ruchu. Ze względu na konstrukcję czujniki mają swój rezonans, co ogranicza pasmo częstości, w którym mogą być zastosowane.

Bardzo ważnym czynnikiem, mającym wpływ na wyniki badań modalnych, związanym z czujnikami jest wybór miejsca zamocowania czujnika. Czujniki powinny być zamocowane w taki sposób, aby nie wpływały na drgania układu oraz były zamocowane w punktach charakterystycznych dla zachowania się konstrukcji. Obecnie coraz częściej do pomiarów drgań w czasie badań modalnych konstrukcji stosuje się czujniki bezstykowe. Jedną z możliwości realizacji tego typu czujników jest wykorzystanie promienia laserowego. Czujniki tego typu umożliwiają pomiar prędkości drgań w zakresie częstości od $\mathrm{O}$ do $50 \mathrm{kHz}$ oraz w zakresie amplitud od O do $100 \mathrm{~mm} / \mathrm{s}$. 
Bardzo istotnym czynnikiem wpływającym na zakres mierzonych częstości ma sposób zamontowania czujnika do badanej konstrukcji. Czujniki można przymocować do badanej konstrukcji za pomocą specjalnego wosku, kleju $(30 \mathrm{kHz})$, magnesu $(7 \mathrm{kHz})$ lub przykręcić za pomocą śruby $(30 \mathrm{kHz})$.

Metoda LSCE została zaimplementowana w programie „VIOMA” służącym do przeprowadzenia operacyjnej analizy modalnej $[22,25]$. W metodzie tej impulsowa funkcja przejścia zastępowana jest funkcją korelacji wzajemnej, której przebieg aproksymowany jest sumą zanikających wykładniczo funkcji harmonicznych. Algorytm składa się $\mathrm{z}$ dwóch kroków: w pierwszym zidentyfikowane zostaja bieguny układu, w drugim na ich podstawie estymowane są postacie drgań własnych układu. Początkowo badany obiekt zostaje zamodelowany wielomianami o określonych rzędach minimalnym i maksymalnym oraz krokiem estymacji. Im większy maksymalny rząd wielomianu, tym lepiej model będzie oddawał rzeczywistą konstrukcję, ale także znacznie wzrośnie złożoność i czas wykonania obliczeń. Na podstawie wybranych biegunów układu następuje estymacja postaci drgań.

\section{Oprogramowanie pomiarowe}

Do pomiarów funkcji przejścia sygnału przez istniejącą konstrukcję (funkcja crosskorelacji) i wygenerowania na jej podstawie diagram stabilizacyjnego wykorzystano najnowocześniejszą aparaturę pomiarową firmy LMS pod nazwa LMS TEST.XPRESS. Oprogramowanie to umożliwia $w$ latwy sposób przeprowadzić analizę modalną całych infrastrukur budowlanych. Program posiada łatwy i przyjemny interfejs przyjazny dla użytkownika - rys.5.

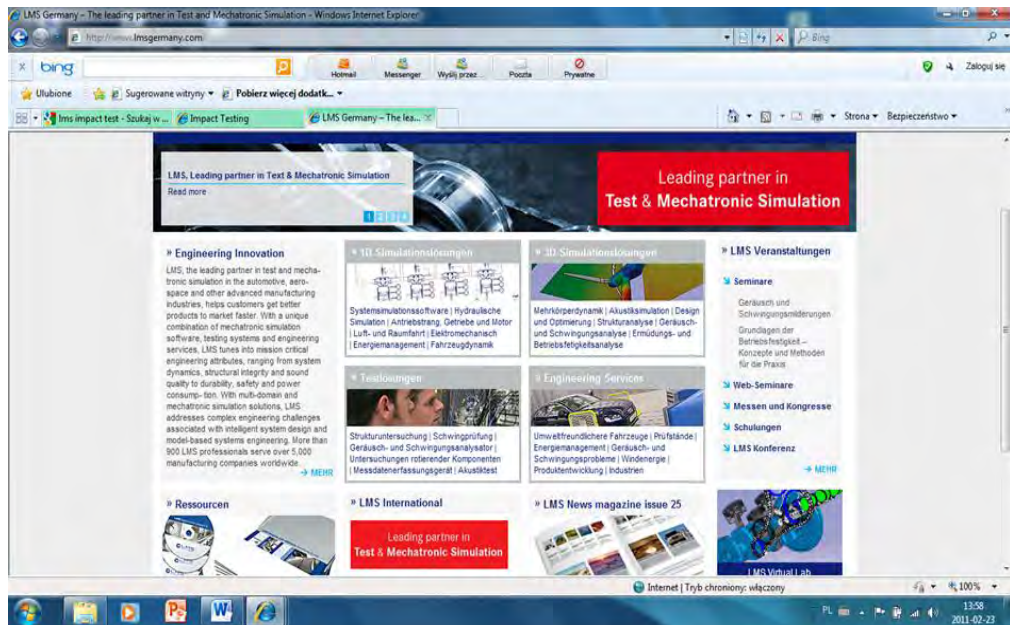

Rys.5. Witryna internetowa producenta oprogramowania

Kolejnym krokiem było zdefiniowanie systemu we wszystkie dane potrzebne do kalibracji toru pomiarowego - rys.6. 
The reliability testing of brick infrastructure with operating modal analysis Badanie niezawodności infrastruktury murowej z użyciem....

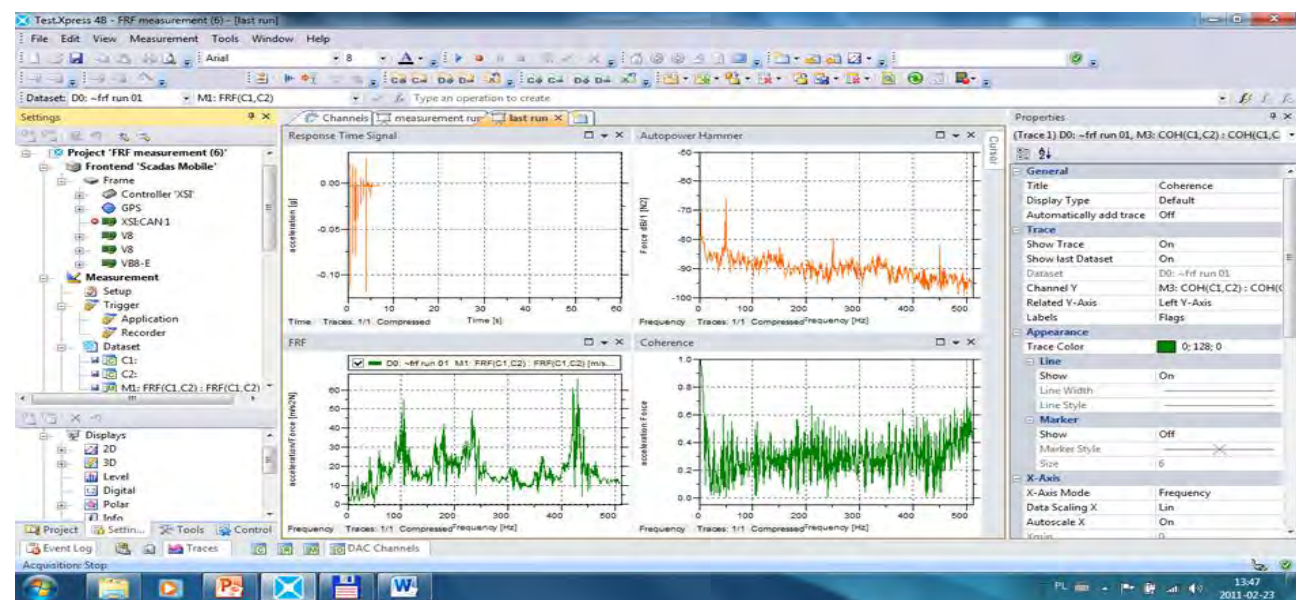

Rys. 6. Interfejs programu LMS

Na potrzeby badań zdefiniowano 8 kanałów pomiarowych. Zgodnie z założeniami teoretycznymi eksploatacyjnej analizy modalnej pierwszy czujnik odpowiedzi zdefiniowano jako czujnik referencyjny, a kolejne 7 jako czujniki odpowiedzi konstrukcji. Dzięki temu można było wyznaczyć funkcje cross - korelacji przejścia sygnału przez badaną konstrukcję.

Na rys.7 pokazano okno kalibracji segmentu i zdefiniowane miejsca i sposób (rys.8) podłączenia czujników. Właściwości każdego $\mathrm{z}$ czujników, który podłaczamy do segmentu definiujemy w oknie widocznym po prawej stronie na rys.7. Znajdują się tam wartości charakterystyczne czujników, które w miarę potrzeb możemy zmieniać.

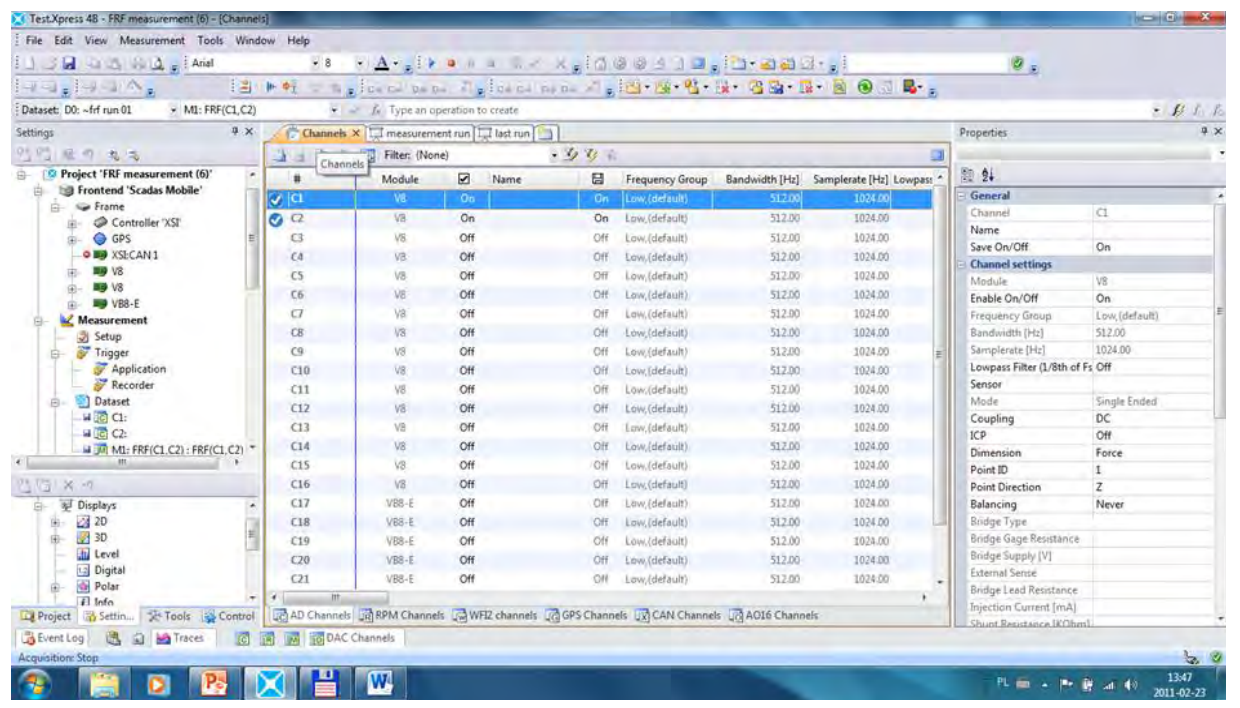

Rys.7. Kalibracja miejsca podłaczenia czujników 


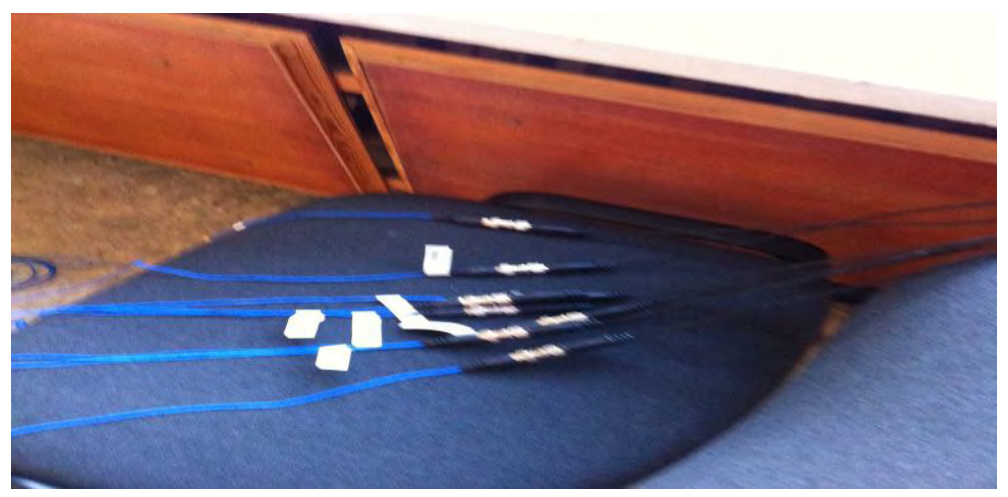

Rys.8. Podłqczanie czujników pomiarowych
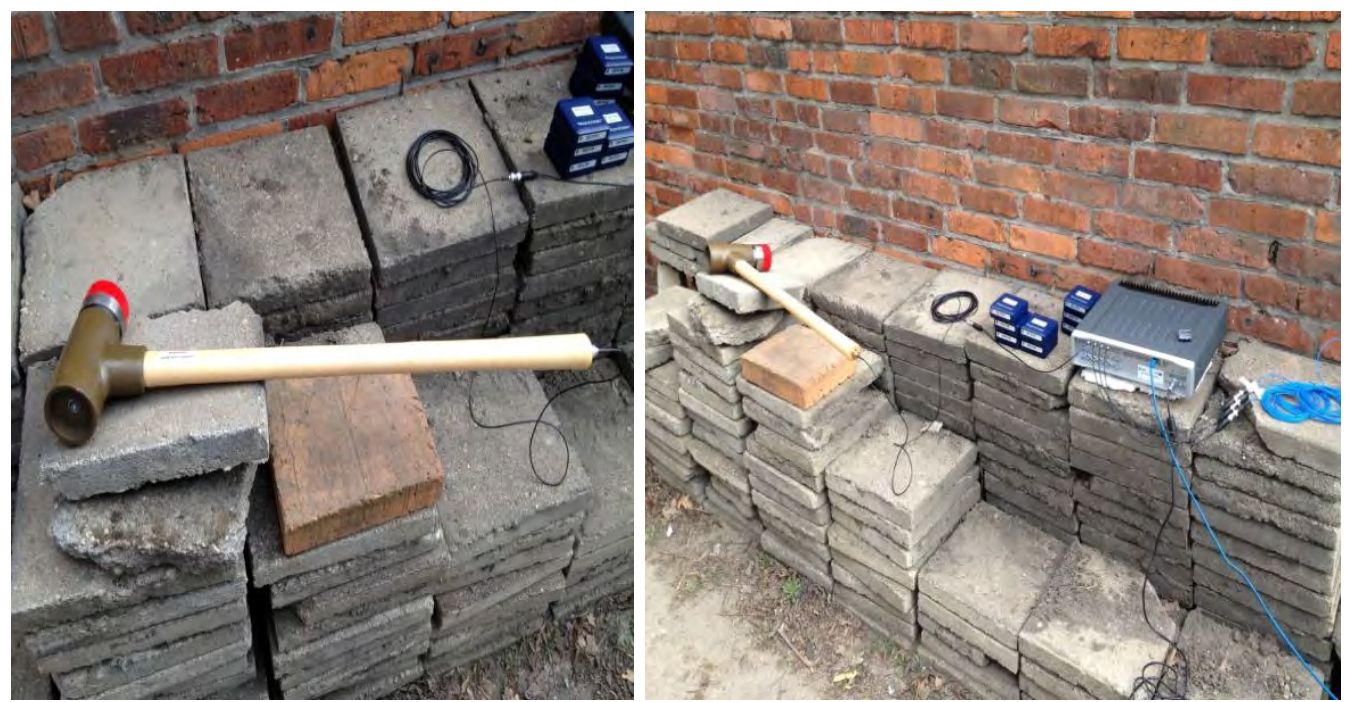

Rys.9. Widok rozstawionej aparatury badawczej

Następnym krokiem było zamodelowanie badanej konstrukcji i rozstawienia czujników w czasie pomiarów. Oprogramowanie LMS i młotek modalny (rys.9) umożliwiają modelowanie i wariantowanie badań konstrukcji. Poniżej przedstawiono zdjęcia rzeczywistych badanych konstrukcji. Badania przeprowadzono na istniejącej konstrukcji budowlanej. Był nią mur ceglany o grubości $0,18 \mathrm{~m}$ i wysokości $\mathrm{h}=2,00 \mathrm{~m}$. Konstrukcję murową badano w miejscu uszkodzenia - rys.10, które generowało spadek naprężeń i groziło bezpieczeństwu konstrukcji. Dla porównania badano także konstrukcje murową w miejscu uznanym za prawidłowy stan konstrukcji. 
The reliability testing of brick infrastructure with operating modal analysis Badanie niezawodności infrastruktury murowej z użyciem....

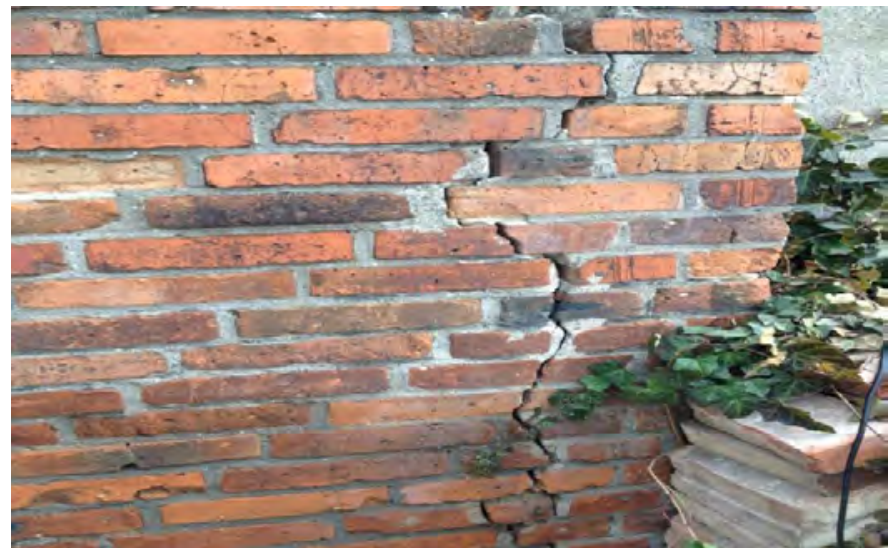

Rys.10. Widok uszkodzonej konstrukcji murowej

\section{Wyniki badań}

W czasie badań wygenerowano funkcje cross - korelacji pomiędzy punktem referencyjnym (czujnik C1), którego umiejscowienie narzuca nam teoria związana z eksploatacyjną analizą modalna, a 7-ma czujnikami rozmieszczonymi na konstrukcji. Dzięki wygenerowaniu funkcji cross-power spectrum w dalszym etapie możliwe jest wygenerowanie $\mathrm{z}$ niej diagramów stabilizacyjnych i częstości drgań własnych. Można tu zauważyć różnice między dwoma rodzajami analizy modalnej. W eksperymentalnej analizie modalnej diagramy stabilizacyjne są generowane $\mathrm{z}$ przebiegu funkcji FRF, (wymuszenie - odpowiedź), a w eksploatacyjnej (odpowiedź w punkcie referencyjnym do odpowiedzi w punktach mocowania czujników). Dla zobrazowania zmian w konstrukcji (gdyż są to pierwsze badania tego typu) wykonano pomiary w kilku wariantach. Po pierwsze były to badania konstrukcji zdatnej i niezdatnej, bez ingerencji z zewnątrz. Badania porównawcze dla konstrukcji zdatnej i niezdatnej prowadzono przy jednoczesnym wymuszeniu drgań - poprzez rytmiczne pukanie w konstrukcję, co trwało każdorazowo 30 sekund. Poniżej przedstawiono wyniki badań w postaci wizualizacji diagramów stabilizacji i odkształceń zachodzących w konstrukcji.

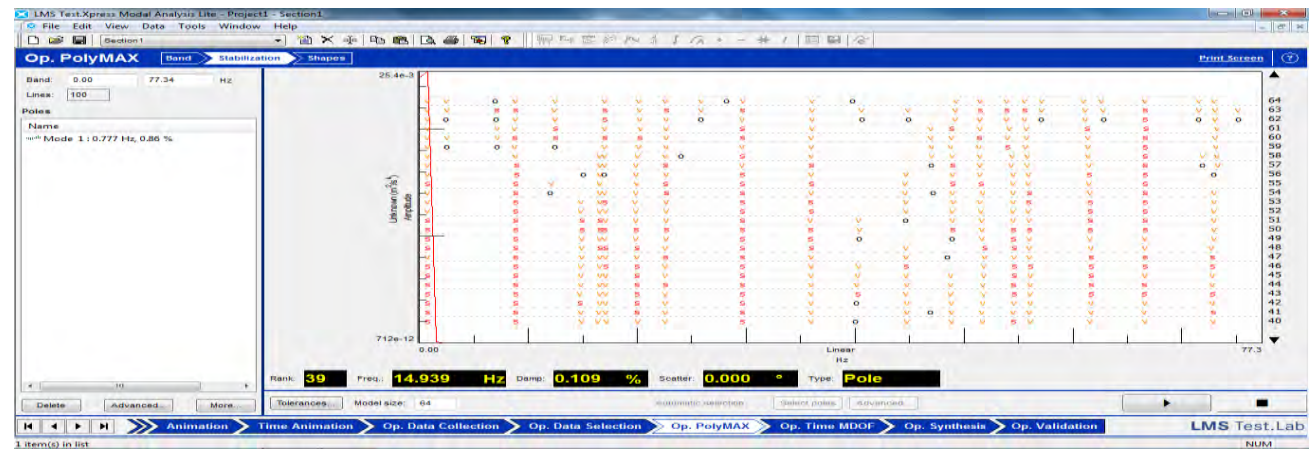

Rys.11. Diagram stabilizacyjny dla zdatnego muru ceglanego (OAM) 


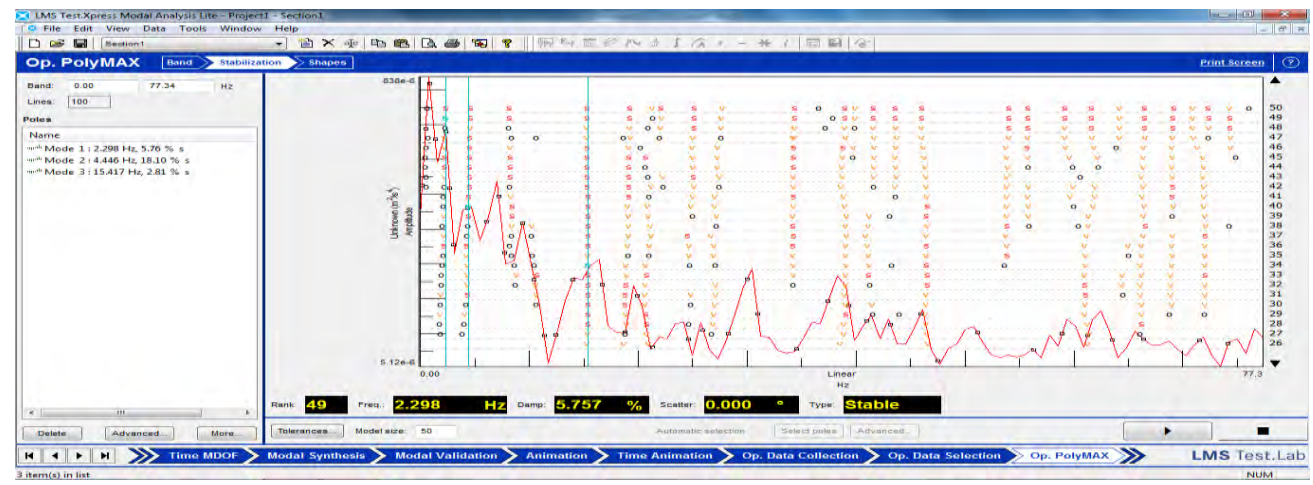

Rys. 12. Diagram stabilizacyjny dla uszkodzonego muru ceglanego (OAM)

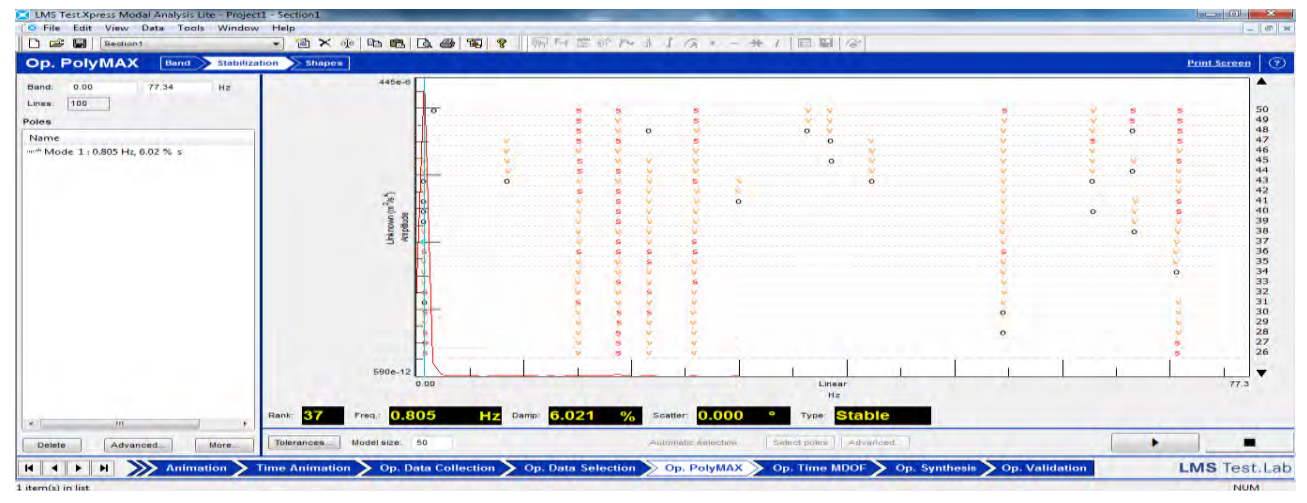

Rys.13. Diagram stabilizacyjny dla zdatnego muru z wymuszeniem drgań (OAM)

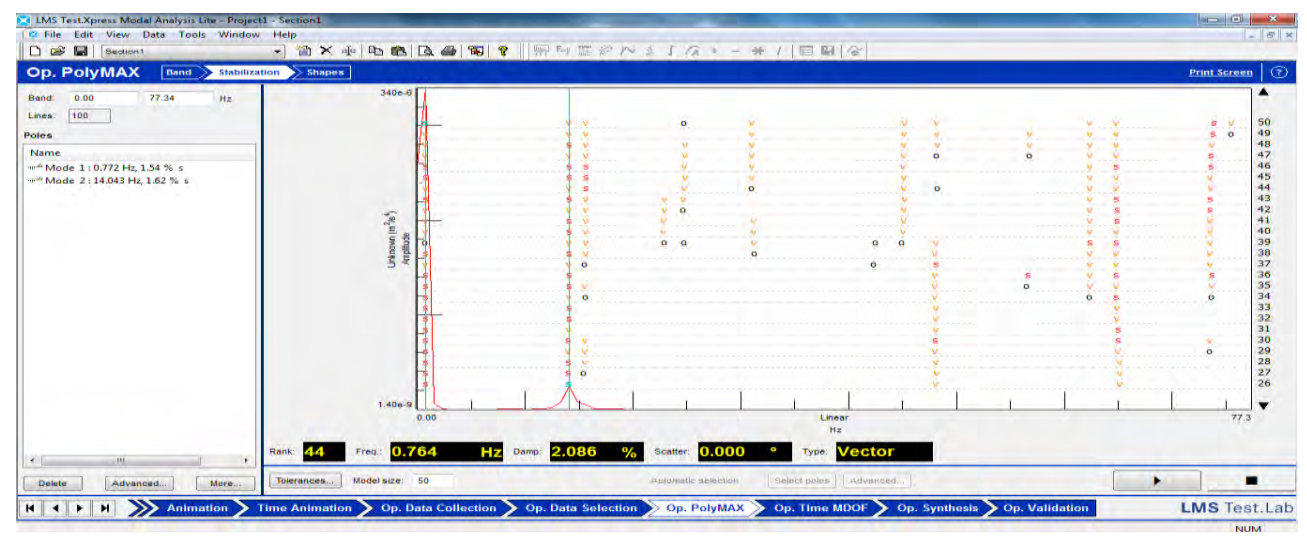

Rys.14. Diagram stabilizacyjny dla uszkodzonego muru z wymuszeniem drgań (OAM)

Poniżej przedstawiono tabelaryczne zestawienie częstości drgań własnych wygenerowanych dla pomiarów istniejącej konstrukcji murowej - tablical. 
The reliability testing of brick infrastructure with operating modal analysis Badanie niezawodności infrastruktury murowej z użyciem....

Tablica 1. Zestawienie częstości drgań własnych w czasie badań konstrukcji muru ceglanego

\begin{tabular}{|c|c|c|}
\hline WYMUSZENIA & Element zdatny & Element uszkodzony \\
\hline z wymuszeniem EAM & $865,612 \mathrm{~Hz}$ & $1025,813 \mathrm{~Hz}$ \\
& & $1060,857 \mathrm{~Hz}$ \\
& & $1112,476 \mathrm{~Hz}$ \\
& & $1121,607 \mathrm{~Hz}$ \\
\hline bez wymuszenia OAM & $0,777 \mathrm{~Hz}$ & $2,289 \mathrm{~Hz}$ \\
& & $4,446 \mathrm{~Hz}$ \\
& & $15,417 \mathrm{~Hz}$ \\
\hline z wymuszeniem OAM & $0,805 \mathrm{HZ}$ & $0,772 \mathrm{~Hz}$ \\
& & $14,043 \mathrm{~Hz}$ \\
\hline
\end{tabular}

\section{Wnioski}

Przedstawione wyniki badań wskazują na fakt, że istnieje możliwość rozróżniania własności materiałowych konstrukcji budowlanych metodami analizy modalnej, co ma wpływ na możliwość rozróżniania stopnia ich degradacji.

Badania również potwierdziły przydatność aparatury i oprogramowania LMS do badań z eksploatacyjnej analizy modalnej wykonywanych na rzeczywistych konstrukcjach budowlanych.

Z przedstawionych wyników można wyprowadzić następujące wnioski:

- badania częstości drgań własnych i ich graficzne przedstawienie ukazują różnice pomiędzy konstrukcją zdatną i uszkodzoną;

- wygenerowano częstości drgań własnych dla konstrukcji muru zdatnego (1Hz), a dla uszkodzonego muru możliwe było wygenerowanie kilku częstości drgań własnych $(4,45 \mathrm{~Hz}, 14,04 \mathrm{~Hz}, 15,42 \mathrm{~Hz}$;

- można zauważyć, że stan zdatny konstrukcji jest opisany jedną częstością drgań własnych, a stan konstrukcji uszkodzonej można opisać za pomocą trzech i więcej częstościami własnymi;

- możliwe jest określenie stanu zagrożenia konstrukcji na podstawie badanych częstości drgań własnych, co wymaga jednak wielu eksperymentów dla przyjęcia poziomów zdatności.

\section{Bibliografia}

[1] Ameliańczyk A.: Optymalizacja wielokryterialna w problemach sterowania i zarządzania. Ossolineum, Wrocław 1984.

[2] Bendat J. S., Piersol A. G.: Metody analizy i pomiaru sygnałów losowych. PWN, Warszawa 1976.

[3] Brunarski L.: Określenie klasy betonu na podstawie diagnostycznych badań konstrukcji. Konferencja Ustroń - Gliwice 1998.

[4] Brunarski L.: Ocena wytrzymałości betonu w konstrukcji. Kwartalnik Prace Instytutu Techniki Budowlanej, nr 2-3/1998.

[5] Brunarski L.: Nieniszczace metody badania betonu. Arkady, Warszawa 1996.

[6] Ciesielski R.: Diagnostyka dynamiczna w budownictwie. Przegląd Budowlany, nr1/1993.

[7] Ciesielski R.: Nowe możliwości analizy i diagnostyki budowli zabytkowych. Inżynieria i Budownictwo, nr 9/1998. 
[8] Ciesielski R.: Wpływ obciążeń dynamicznych na konstrukcje murowe. Warsztat pracy projektanta konstrukcji, Ustroń 1999.

[9] Ciesielski R. ii: Przypadki oceny a posteriori wpływów parasejsmicznych na budowle. Konferencja: Awarie Budowlane, Szczecin - Międzyzdroje 1995.

[10] Chmielewski T., Zembaty Z.: Podstawy dynamiki budowli. Wydawnictwo ARKADY, Warszawa 1998.

[11] Chmielewski T., Nowak H.: Mechanika budowli. WNT, Warszawa 1996.

[12] Drobiec Ł., Jasiński R., Piekarczyk A.: Lokalizacja wad konstrukcji i stali zbrojeniowej - metody. XXI Konferencja, Szczyrk 2006.

[13] Der Kiureghian A.: A response spectrum method for random vibrations. Rep. No. UCB/EERC-80-/15, Earth. Eng. Research Center, Univ. of California, Berkeley 1980.

[14] Giergiel J., Uhl T.: Identyfikacja układów mechanicznych. PWN, Warszawa, 1990.

[15] Giergiel J.: Drgania mechaniczne. AGH, Kraków 2000.

[16] Godyeki - Ćwirko T, Mielczarek Z:: O badaniach i stosowaniu konstrukcji drewniano - żelbetowych. Inżynieria i Budownictwo, 5/1997.

[17] Gromysz K. i inni: Nowoczesne metody diagnostyki konstrukcji żelbetowych. Konferencja Warsztat Pracy Projektanta Konstrukcji, Ustron 2002.

[18] Łukasiewicz M.: Badania przydatności eksploatacyjnej analizy modalnej w diagnozowaniu silników spalinowych. Rozprawa doktorska, UTP Bydgoszcz, 2008.

[19] Moczko A.: Nowe metody nieniszczącej diagnostyki konstrukcji betonowych. INWITU, Zakopane 1999.

[20] Podhorecki A.: Diagnostyka budynków i budowli. PTDT - ITEE, Rozdział 16 w Inżynierii Diagnostyki Maszyn, Radom 2004.

[21] Runkiewicz L.: Stosowanie metod nieniszczących do oceny materiałów przy certyfikacji obiektów budowlanych. Konferencja Badań Nieniszczących, Poznań Licheń 2004.

[22] Runkiewicz L.: Stosowanie metod nieniszczacych w kontroli produkcji wyrobów i elementów budowlanych. Konferencja Badań Nieniszczących, Zakopane 2005.

[23] Runkiewicz L., Rodzik W.: Badania nieniszczące wytrzymałości murowanych obiektów zabytkowych. Inżynieria i Budownictwo, nr 2/1990.

[24] Uhl T.: Komputerowo wspomagana identyfikacja modeli konstrukcji mechanicznych. WNT, Warszawa 1997.

[25] Uhl T., Lisowski W.: In-operation modal analysis. Wydawnictwo KRiDM AGH, Kraków, 2001.

[26] Uhl T.: Zastosowanie modeli dynamicznych układów mechanicznych w systemach monitorowania i diagnozowania stanu maszyn, V Conference on Dynamical Systems Theory and Applications, Łódź 1999.

[27] Uhl T.: Diagnostyka przez identyfikacje, Konferencja Diagnostyka Pojazdów, Bydgoszcz 1996.

[28] Uhl T.: Zastosowanie analizy modalnej w diagnostyce konstrukcji, Diagnostyka vol.23, 2000.

[29] Uhl T., Lisowski W.: Eksploatacyjna analiza modalna i jej zastosowania, Akademia Górniczo - Hutnicza Kraków 1999.

[30] Uhl T., Lisowski W.: Praktyczne problemy analizy modalnej konstrukcji, CCATIE, Kraków 1996. 
The reliability testing of brick infrastructure with operating modal analysis Badanie niezawodności infrastruktury murowej z użyciem....

[31] Żóltowski M.: Selection information on identification the state machine. UWM, Acta Academia 310, Olsztyn 2007.

[32] Żółtowski M.: Badania destrukcji wybranych materiałów. Materiały konferencji, REGENERACJA '06. Bydgoszcz 2006.

[33] Żółtowski M.: Komputerowe wspomaganie zarządzania systemem eksploatacji $\mathrm{w}$ przedsiębiorstwie produkcyjnym. Zintegrowane zarządzanie. Oficyna Wydawnicza Polskiego Towarzystwa Zarządzania Produkcja, Opole t. 2. 2011. s. 243-257.

[34] Żółtowski M.: Badania materiałów budowlanych w aspekcie bezpieczeństwa konstrukcji. Materiały konferencyjne. Częstochowa 2010.

[35] Żółtowski M.: Informatyczne systemy zarządzania w inżynierii produkcji. ITE-PIB Radam 2011.

[36] Żółtowski M.: Analiza modalna w badaniu materiałów budowlanych. ITE-PIB, Radom 2011.

Pracę wykonano w ramach projektu POIG nr. WND-POIG.01.03.01-00-212/09 